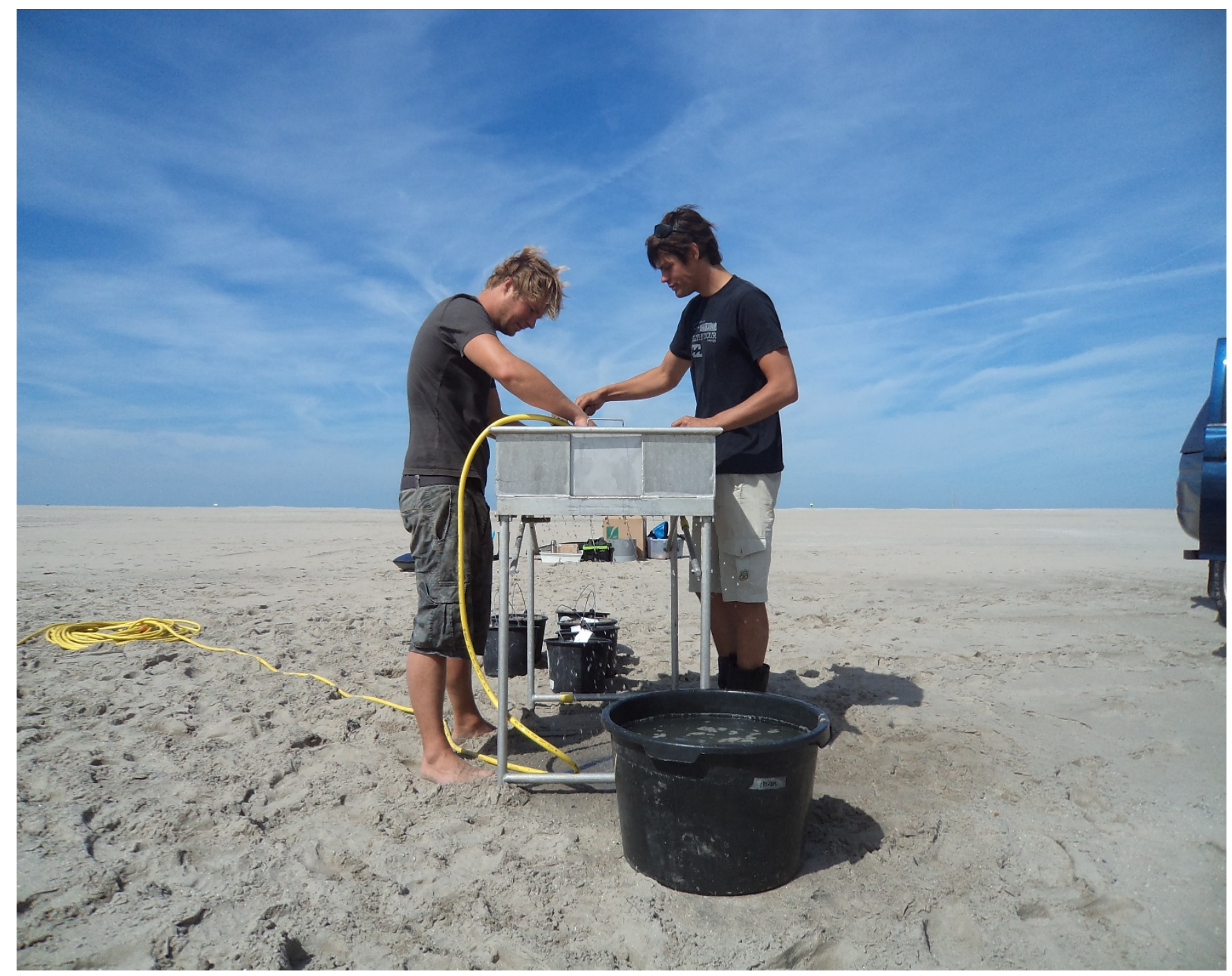

\title{
Bodemdiergemeenschap in de vooroever en op het natte strand van de zandmotor in het najaar 2017
}

Datarapport 


\section{Bodemdiergemeenschap in de vooroever en op het natte strand van de Zandmotor in het najaar 2017}

Datarapport

Auteur(s): $\quad$ Jeroen Wijsman, Douwe van den Ende en Emiel Brummelhuis

Publicatiedatum: 10-10-2018

Wageningen Marine Research Yerseke, oktober 2018

Wageningen Marine Research rapport C073/18 
Jeroen Wijsman, Douwe van den Ende en Emiel Brummelhuis, 2018. Bodemdiergemeenschap in de vooroever en op het natte strand van de Zandmotor in het najaar 2017; Datarapport. Wageningen Marine Research Wageningen UR (University \& Research centre), Wageningen Marine Research rapport C073/18. 99 blz.;

Keywords: Zandmotor, Benthos, Sediment, Bodemschaaf, Van Veen happer, Strandbemonstering.

Opdrachtgever: Rijkswaterstaat WVL

T.a.v.: Petra Damsma

Dit rapport is gratis te downloaden van https://doi.org/10.18174/461892

Wageningen Marine Research verstrekt geen gedrukte exemplaren van rapporten.

Wageningen Marine Research Wageningen UR is ISO 9001:2008 gecertificeerd.

Foto omslag: Jeroen Wijsman

(C) 2018 Wageningen Marine Research Wageningen UR

Wageningen Marine Research, onderdeel van Stichting Wageningen Research KvK nr. 09098104,

IMARES BTW nr. NL 8113.83.696.B16

Code BIC/SWIFT address: RABONL2U

IBAN code: NL 73 RABO 0373599285
De Directie van Wageningen Marine Research is niet aansprakelijk voor gevolgschade, noch voor schade welke voortvloeit uit toepassingen van de resultaten van werkzaamheden of andere gegevens verkregen van Wageningen Marine Research opdrachtgever vrijwaart Wageningen Marine Research van aanspraken van derden in verband met deze toepassing.

Dit rapport is vervaardigd op verzoek van de opdrachtgever hierboven aangegeven en is zijn eigendom. Niets uit dit rapport mag weergegeven en/of gepubliceerd worden, gefotokopieerd of op enige andere manier gebruikt worden zonder schriftelijke toestemming van de opdrachtgever. 


\section{Inhoud}

$\begin{array}{lr}\text { Samenvatting } & \mathbf{5}\end{array}$

$1 \quad$ Inleiding $\quad 6$

$\begin{array}{lll}1.1 & \text { Achtergrond } & 6\end{array}$

$\begin{array}{ll}1.2 \text { Aanpak } & 7\end{array}$

$\begin{array}{lll}1.3 & \text { Doelstelling } & 8\end{array}$

1.4 Dankwoord $\quad 8$

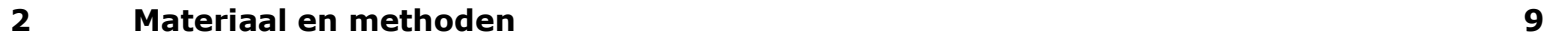

2.1 Opzet monitoring $\quad 9$

2.2 Weerscondities tijdens de bemonstering 13

$\begin{array}{ll}2.3 \text { Sedimentsamenstelling } & 15\end{array}$

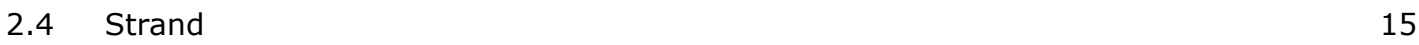

2.4.1 Bemonstering $\quad 15$

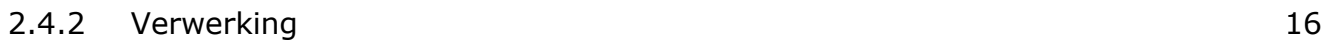

2.5 Bodemschaaf 16

2.5.1 Bemonstering 16

$\begin{array}{lll}2.5 .2 & \text { Verwerking } & 18\end{array}$

2.6 Van Veen happer 19

2.6.1 Bemonstering $\quad 19$

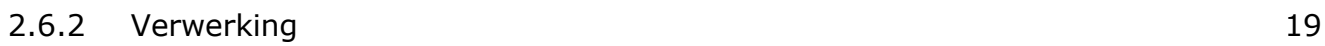

$\begin{array}{ll}2.7 & \text { Data analyse }\end{array}$

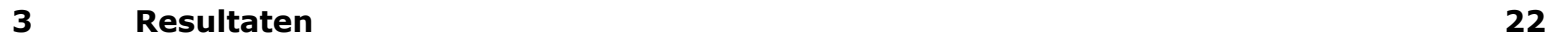

3.1 Sediment $\quad 22$

3.1.1 Korrelgrootteverdeling $\quad 22$

$\begin{array}{ll}3.1 .2 & \text { Vergelijk voorgaande jaren }\end{array}$

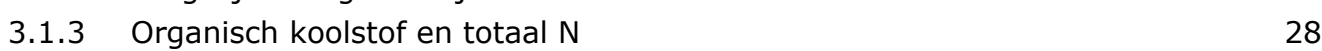

$\begin{array}{lll}3.2 & \text { Bodemschaaf } & 30\end{array}$

$\begin{array}{lll}3.2 .1 & \text { Overzicht } & 30\end{array}$

3.2.2 Relatie met waterdiepte 33

3.2.3 Relatie met sedimentsamenstelling $\quad 36$

$\begin{array}{lll}3.2 .4 & \text { Ruimtelijke verspreiding } & 37\end{array}$

$\begin{array}{lll}3.2 .5 & \text { Multivariate analyses } & 38\end{array}$

$\begin{array}{lll}3.3 & \text { Van Veen bemonstering } & 44\end{array}$

3.3.1 Overzicht $\quad 44$

$\begin{array}{lll}3.3 .2 & \text { Relatie met waterdiepte } & 48\end{array}$

$\begin{array}{lll}\text { 3.3.3 Relatie met sedimentsamenstelling } & 50\end{array}$

$\begin{array}{lll}\text { 3.3.4 Ruimtelijke verspreiding } & 51\end{array}$

3.3.5 Multivariate analyses $\quad 53$

$\begin{array}{lll}3.4 & \text { Strandbemonstering } & 58\end{array}$

$\begin{array}{lll}3.4 .1 & \text { Overzicht } & 58\end{array}$

$\begin{array}{lll}3.4 .2 & \text { Relatie met droogval } & 59\end{array}$

$\begin{array}{lll}3.4 .3 & \text { Ruimtelijke verspreiding } & 60\end{array}$

4 Conclusies en discussie $\quad 62$

$\begin{array}{llr}5 & \text { Kwaliteitsborging } & 64\end{array}$ 
Bijlage 1 Bemonsteringslocaties Van Veen monsters

Bijlage 2 Bemonsteringslocaties strand

Bijlage 3 Bemonsteringslocaties bodemschaaf

73

Bijlage 4 Sedimentsamenstelling

76

Bijlage $5 \quad$ Verspreiding enkele bodemdiersoorten uit de bodemschaaf 83

Bijlage 6 Clusteranalyse data bodemschaaf voorgaande jaren

88

Bijlage 7 Verspreiding enkele bodemdiersoorten uit de Van Veen bemonstering 


\section{Samenvatting}

Van 25 september tot en met 12 oktober 2017 zijn er bemonsteringen uitgevoerd van de bodemdiergemeenschap en sedimentkarakteristieken op en rond de Zandmotor. In totaal zijn er 120 stations in de vooroever bemonsterd met zowel een Van Veen happer als een bodemschaaf. Tevens zijn er 70 stations bemonsterd op het strand tussen de hoog- en laagwater lijn. Aanvullend zijn er 330 sedimentmonsters genomen, deels op de stations waar ook bodemdieren zijn bemonsterd (190 stations), en deels op tussenliggende transecten (140 stations). De bemonsterde stations liggen op 12 parallelle transecten loodrecht op de voormalige kustlijn met een onderlinge afstand van 800 tot 1000 meter.

In voorliggende rapportage worden de resultaten van de resultaten van de analyses op sedimentsamenstelling (korrelgrootteverdeling en organisch stofgehalte) en bodemdiergemeenschap gepresenteerd en vergeleken met voorgaande jaren (2010, 2012, 2013 en 2015).

Er zijn duidelijke ruimtelijke patronen in sedimentsamenstelling met gebieden waar het sediment relatief grof is (kop van de Zandmotor en het meest noordelijk deel van onderzoeksgebied) en gebieden waar het sediment fijner is (net ten noorden en ten zuiden van de Zandmotor en in het meest zuidelijke deel van het onderzoeksgebied). Deels zijn deze patronen het directe gevolg van de Zandmotor.

De gemiddelde biomassa aan bodemdieren in de bodemschaaf in 2017 (194 gram versgewicht $\mathrm{m}^{-2}$ ) is hoger dan in de jaren 2010, 2012 en 2015 (respectievelijk 57, 91 en 161 gram versgewicht $\mathrm{m}^{-2}$ ), maar lager dan in 2013 (430 gram versgewicht $\mathrm{m}^{-2}$ ), als gevolg van een hoge biomassa Ensis spp. in dat jaar. Het gemiddeld aantal taxa per monster (6.8 taxa per monster) is vergelijkbaar met voorgaande jaren (tussen de 5 en 7 taxa per monster, maar hoger dan in 2010, voor de aanleg van de Zandmotor (2.7 taxa per monster). In de Van Veen bemonstering zijn gemiddeld meer taxa aangetroffen (in 2017, 14.4 taxa per monster) dan in de bodemschaaf. Dit komt door de fijnere maaswijdte van de zeef bij de Van Veen bemonstering $(1 \mathrm{~mm}$ ) ten opzichte van de bodemschaaf ( 5 $\mathrm{mm}$ ). In het najaar van 2017 zijn er relatief veel zaagjes (Donax vittatus), halfgeknotte strandschelpen (Spisula subtruncata), nonnetjes (Limecola balthica) en Nephtys spp. aangetroffen in het onderzoeksgebied.

Het totale bestand aan bodemdieren (dichtheid, biomassa en aantal soorten) neemt toe met de waterdiepte. Vooral de ondiepe zone (tot en met -5 meter NAP) is arm en wordt gekenmerkt door specifieke soorten zoals de breedpootkrab (Portumnus latipes) en de gemshorenworm (Scolelepis (Scolelepis) squamata). Op grotere diepten (dieper dan -6 m NAP) neemt de dichtheid, biomassa en het aantal soorten per monster sterk toe, met de hoogste waarden op dieptes groter dan $11 \mathrm{~m}$.

De Zandmotor heeft geleid tot een ruimtelijke verdeling van de bodemdiergemeenschap in het onderzoeksgebied. Dit is waarschijnlijk het directe gevolg van de veranderde hydro- en morfodynamiek. Sinds de aanleg van de Zandmotor heeft de bodemdiergemeenschap zich ontwikkeld, niet alleen in het suppletiegebied, maar ook in de gebieden ten noorden en ten zuiden van de Zandmotor. Zolang de Zandmotor de hydrodynamische en morfologische processen blijft beïnvloeden is de verwachting dat de bodemdiergemeenschap niet zal terugkeren naar de situatie van voor de aanleg. 


\section{$1 \quad$ Inleiding}

\section{$1.1 \quad$ Achtergrond}

Tussen maart en oktober 2011 is er in opdracht van Rijkswaterstaat en de Provincie Zuid-Holland een grootschalige strandsuppletie aangelegd tussen Ter Heijde en Kijkduin, de Zandmotor. De Zandmotor is aangelegd als een schiereiland in de vorm van een haak. Voor de aanleg is ongeveer 21.5 miljoen $\mathrm{m}^{3}$ (volumes in het beun) zand gebruikt, waarvan 19 miljoen $\mathrm{m}^{3}$ is gebruikt voor de aanleg van de haak en de rest voor additionele vooroeversuppleties ten noorden en ten zuiden van de zandhaak. Bij aanleg stak de Zandmotor $1.5 \mathrm{~km}$ de zee in en was aan het strand $2 \mathrm{~km}$ breed. De Zandmotor is het eerste experiment met een zogenaamde megasuppletie.

Het idee is dat de Zandmotor langzaam erodeert door wind, golven en getijdenbeweging en dat het zand de kustlijn ten noorden van de Zandmotor versterkt. De Zandmotor is een alternatief voor strand- en vooroeversuppleties die iedere 4-5 jaar dienen te worden herhaald. De doelstelling van dit experiment is om na te gaan of het eenmalig aanbrengen van een grote hoeveelheid zand uiteindelijk goedkoper, effectiever en natuurvriendelijker is dan het herhaaldelijk aanbrengen van kleinere hoeveelheden zoals gebeurt bij de reguliere vooroever- en strandsuppleties. Daarnaast is de vraag of een suppletie in deze vorm een aanwinst vormt voor de recreatie.

Het project Monitoring en Evaluatie Zandmotor is opgestart om de ontwikkelingen op en rond de Zandmotor te volgen en hier kennis en ervaring uit op te doen. Uitgangspunt van de monitoring zijn de vier hoofddoelstellingen en de beheerdoelstelling van de Zandmotor zoals geformuleerd in het MER (Fiselier, 2010):

- $\quad$ MER 1: Het stimuleren van natuurlijke duinaangroei in het kustgebied tussen Hoek van Holland en Scheveningen voor veiligheid, natuur en recreatie;

- $\quad$ MER 2: Het genereren van kennisontwikkeling en innovatie om de vraag te beantwoorden in welke mate kustonderhoud meerwaarde voor recreatie en natuur kan opleveren;

- MER 3: Het toevoegen van aantrekkelijk recreatie- en natuurgebied aan de Delflandse Kust.

- MER 4: Het vergaren van voldoende en adequate informatie om de Zandmotor en omgeving op een goede wijze te kunnen beheren;

Voorliggend meetrapport richt zich op de ontwikkeling van het benthos in de vooroever en het intergetijdenstrand van de Zandmotor, en daarmee op invulling van MER 2 en MER 3.

De Zandmotor kan op verschillende manieren effect hebben op de bodemdiergemeenschap op het strand en de vooroever. De verwachting is dat een Zandmotor een levensduur heeft van ca 20 jaar. Dat betekent dat bij kustsuppleties met een Zandmotor over een relatief klein oppervlak de bodemdiergemeenschap iedere 20 jaar bedekt zal worden met een dikke laag zand. Het ruimere gebied rondom de Zandmotor zal geleidelijk worden voorzien met zand dat erodeert van de Zandmotor. Aangenomen wordt dat een groter aantal normaliter in de kustzone voorkomende soorten bodemdieren om kan gaan met deze geleidelijke bedekking met zand. Bij reguliere vooroever- en strandsuppleties daarentegen wordt de bodemdiergemeenschap over een groter oppervlak iedere 4-5 jaar met een laag sediment bedekt. De verwachting is dat deze innovatieve vorm van kustsuppletie zich zal uiten in de samenstelling van de bodemdiergemeenschap waarbij er betere kansen zijn voor langlevende soorten. Daarnaast is de verwachting dat de vorm van de Zandmotor zal leiden tot een grotere diversiteit in habitats (stroomsnelheid, golfenergie en sedimentsamenstelling) dan normaliter voorkomt in het gebied. Dit kan een effect hebben op de ruimtelijke verdeling van de bodemdiergemeenschap en op het aantal soorten in de kustzone rondom de Zandmotor. Het benthos is een belangrijke voedselbron voor hogere trofische niveaus (vogels en vis en indirect zeezoogdieren) en daarmee kunnen effecten van de Zandmotor op de bodemdiergemeenschap (samenstelling en biomassa) ook effect hebben op de hogere trofische niveaus. 
De hoge abstracte doelen en beheersdoelstellingen zijn vertaald in meer concrete evaluatievragen (Ebbens en Fiselier, 2010). Het project Monitoring- en Evaluatie Pilot Zandmotor is erop gericht om informatie te verzamelen om de evaluatievragen te kunnen adresseren. De opzet van de monitoring is beschreven in Tonnon et al. (2011) (Fase 2, 2011 t/m 2016) en Taal et al. (2017) (Fase 3, 2017 t/m 2021). De monitoring is reeds in 2010 gestart (Fase 1) met een $T_{0}$ meting (Tonnon en Baptist, 2011; Wijsman en Verduin, 2011). De resultaten van Fase 2 zijn geëvalueerd in een samenvattende rapportage (Taal et al., 2016a; b).

Voorliggend datarapport richt zich op de doelen en vragen die betrekking hebben op het benthos van het strand en de ondiepe kustzone van de Zandmotor. De relevante evaluatievragen behorende bij de MER doelen zijn de volgende (Taal et al., 2017):

\section{MER doel 2:}

- Evaluatievraag EF2-2: Heeft een megasuppletie als de Zandmotor een meerwaarde voor de natuur ten opzichte van reguliere suppleties? En waardoor wordt deze meerwaarde veroorzaakt?.

- Subvraag EF2-2a: Via welke mechanismen veroorzaakt de Zandmotor veranderingen in de gradiënten in sedimentsamenstelling (korrelgrootteverdeling en organisch stof gehalte) op het natte strand en de vooroever?

- Subvraag EF2-2b: Helpt het eenmalig neerleggen van een grote hoeveelheid zand om een natuurlijkere bodemdiersamenstelling in de ondiepe kustzone te krijgen in vergelijking met een regulier suppletieschema en leidt dit ook tot langer levende soorten?

\section{MER doel 3:}

- Evaluatievraag EF3-1b: Hoe ontwikkelt de (tijdelijke) nieuwe natuur zich in de lagune ${ }^{1}$ en op de vooroever van de Zandmotor?

- subvraag EF3-1b1: Hoe heeft de diversiteit in sedimentsamenstelling zich ontwikkeld in de lagune en de vooroever?

- subvraag EF3-1b2: Heeft de Zandmotor nieuwe habitats en meer variatie in habitats gecreëerd. Leiden deze tot hogere natuurwaarden in intergetijdegebied en ondiepe kustzone? Is dit te kwantificeren voor bodemdieren, vissen, vogels en zeezoogdieren? ${ }^{2}$

- subvraag EF3-1b3: Hoe heeft de bodemdiergemeenschap zich ontwikkeld in de lagune en de vooroever?

\subsection{Aanpak}

Om de effecten van de Zandmotor op de bodemdiergemeenschap te onderzoeken, zijn er in het najaar bemonsteringen uitgevoerd van sediment en bodemdieren op het strand met een steekframe, in de ondiepe kustzone met een Van Veen happer en een bodemschaaf. De Van Veen happer is vooral geschikt voor het bemonsteren van de relatief kleinere (maaswijdte zeef is $1 \mathrm{~mm}$ ), minder zeldzame, in de bodem levende dieren. Het bemonsterde oppervlak is echter beperkt $\left(0.1 \mathrm{~m}^{2}\right)$ ten opzichte van de bemonsterde oppervlakte met de bodemschaaf (ongeveer $15 \mathrm{~m}^{2}$ ). Grotere mobiele en sedentaire, relatief zeldzame dieren, worden daarom beter bemonsterd met een bodemschaaf. Omdat er bij de bodemschaaf gebruik wordt gemaakt van een grotere maaswijdte $(5 \mathrm{~mm})$ worden kleinere organismen zoals Polychaeten gemist. De bemonstering met de bodemschaaf en de Van Veen happer (of een vergelijkbare methode als de boxcorer) vullen elkaar goed aan (Ens et al., 2007) en worden vaker naast elkaar gebruikt (Wijsman et al., 2014).

\footnotetext{
${ }^{1}$ Omdat de lagune niet (meer) wordt bemonsterd zullen hier geen uitspraken over kunnen worden gedaan

${ }^{2}$ Voorliggende studie richt zich op de bodemdieren. Vis en zeezoogdieren worden niet meer gemonitord in Fase 3 . Vogels worden gemonitord in een andere deelstudie
} 


\subsection{Doelstelling}

Het doel van dit datarapport is een overzicht te geven van de resultaten van de bemonstering van het sediment en benthos op het strand en de ondiepe kustzone van de Zandmotor in het najaar van 2017 en een vergelijk met voorgaande jaren. Een dergelijke bemonstering is namelijk eerder uitgevoerd in 2010 (Wijsman en Verduin, 2011), 2011 (Boon en Wijsman, 2012), 2012 (Wijsman, 2014a), 2013 (Wijsman, 2014b) en 2015 (Wijsman, 2016). Door over meerdere jaren te monitoren, kan de jaarlijkse dynamiek in bodemdiersamenstelling worden gevolgd en kan de ontwikkeling van langlevende soorten in kaart worden gebracht. De resultaten van de bemonstering zullen worden gebruikt bij de evaluatie in 2021 waarbij de bovengenoemde evaluatievragen zullen worden geadresseerd.

\subsection{Dankwoord}

Een groot aantal mensen hebben meegewerkt aan de totstandkoming van dit rapport. Allereerst willen we de bemanning van de Ye-42 en de ms Zuiderhaaks en de veldmedewerkers van Wageningen Marine Research (Douwe vd Ende, Yoeri van Esch) voor hun inzet tijdens de bemonstering van de vooroever met de bodemschaaf en de Van Veen happer. De medewerkers van Shore hebben geholpen bij de strandbemonstering. Een groot aantal mensen van Eurofins Aquasense, Bureau Waardenburg en Wageningen Marine Research zijn betrokken bij het uitzoeken en determineren van de het benthos uit de Van Veen en Strandbemonstering. De sedimentanalyses zijn uitgevoerd door Peter van Breugel van het NIOZ in Yerseke. Babeth van der Weide en Margriet van Asch waren verantwoordelijk voor het databeheer bij Wageningen Marine Research. Hierbij willen de auteurs Petra Damsma (Rijkswaterstaat WVL) en vooral Joël Cuperus (Rijkswaterstaat CIV) danken voor hun waardevolle suggesties en aanvullingen op eerdere versies van dit rapport. 


\section{Materiaal en methoden}

\section{$2.1 \quad$ Opzet monitoring}

De bodemdiergemeenschap (benthos) wordt op diverse manieren beïnvloed door strand- en vooroeversuppleties. Een belangrijke vorm van directe impact is dat de oorspronkelijke bodemdiergemeenschap wordt bedekt met een laag sediment waarna deze zich opnieuw kan ontwikkelen (Birklund en Wijsman, 2005; Goldsmit et al., 2014). Het zijn doorgaans de kortlevende, opportunistische soorten die zich als eerste zullen ontwikkelen. Suppleties kunnen ook via een verandering in sedimentsamenstelling effect hebben op de bodemdiergemeenschap (Van der Wal en Van Dalfsen, 2008; Baptist et al., 2009).

Het onderzoeksgebied van de Zandmotor kan grofweg ingedeeld worden in drie gebieden (Figuur 1) Zuid: $\quad H e t$ gebied ten zuiden van de Zandmotor (transect 0 tot en met transect 4, Figuur 1). Als gevolg van het netto kustlangs transport naar het noorden kan worden verwacht dat het zand van de Zandmotor slechts beperkt in dit gebied zal sedimenteren. Mogelijk zal de uitstralende werking van de Zandmotor leiden tot lagere stroomsnelheden in dit gebied waardoor het zal aanzanden met sediment uit het zuiden of vanuit dieper water. Reguliere suppleties zijn dan in de nabije toekomst niet nodig. Indien het gebied, ondanks de uitstralende werking van de Zandmotor blijft eroderen zal het mogelijk in de toekomst weer dienen te worden versterkt door middel van een reguliere (vooroever) suppletie. In dat geval kan het gebied worden beschouwd als een "referentiegebied".

Zandmotor: Dit is het gebied waar de Zandmotor is aangelegd (transect 5 tot en met transect 8, Figuur 1). De oorspronkelijke zeebodem is hier bedekt met een dikke laag zand dat deels permanent boven water uitsteekt. Aan de zeezijde is een sterke dieptegradiënt ontstaan en golven en stroming zorgen hier voor een dynamisch klimaat

Noord: $\quad$ Het gebied ten noorden van de Zandmotor (transect 9 tot en met transect 12, Figuur 1). Als gevolg van de dominante stroomrichting naar het noorden wordt verwacht dat het meeste zand van de Zandmotor ten noorden van de Zandmotor zal worden afgezet. Verwacht wordt dat het gebied als gevolg van de Zandmotor een depositiegebied zal worden met een sterk reliëf. Als gevolg van de geleidelijke aanzanding met zand afkomstig van de Zandmotor zullen reguliere suppleties in de nabije toekomst overbodig zijn en krijgt het bodemleven de kans zich te herstellen. 


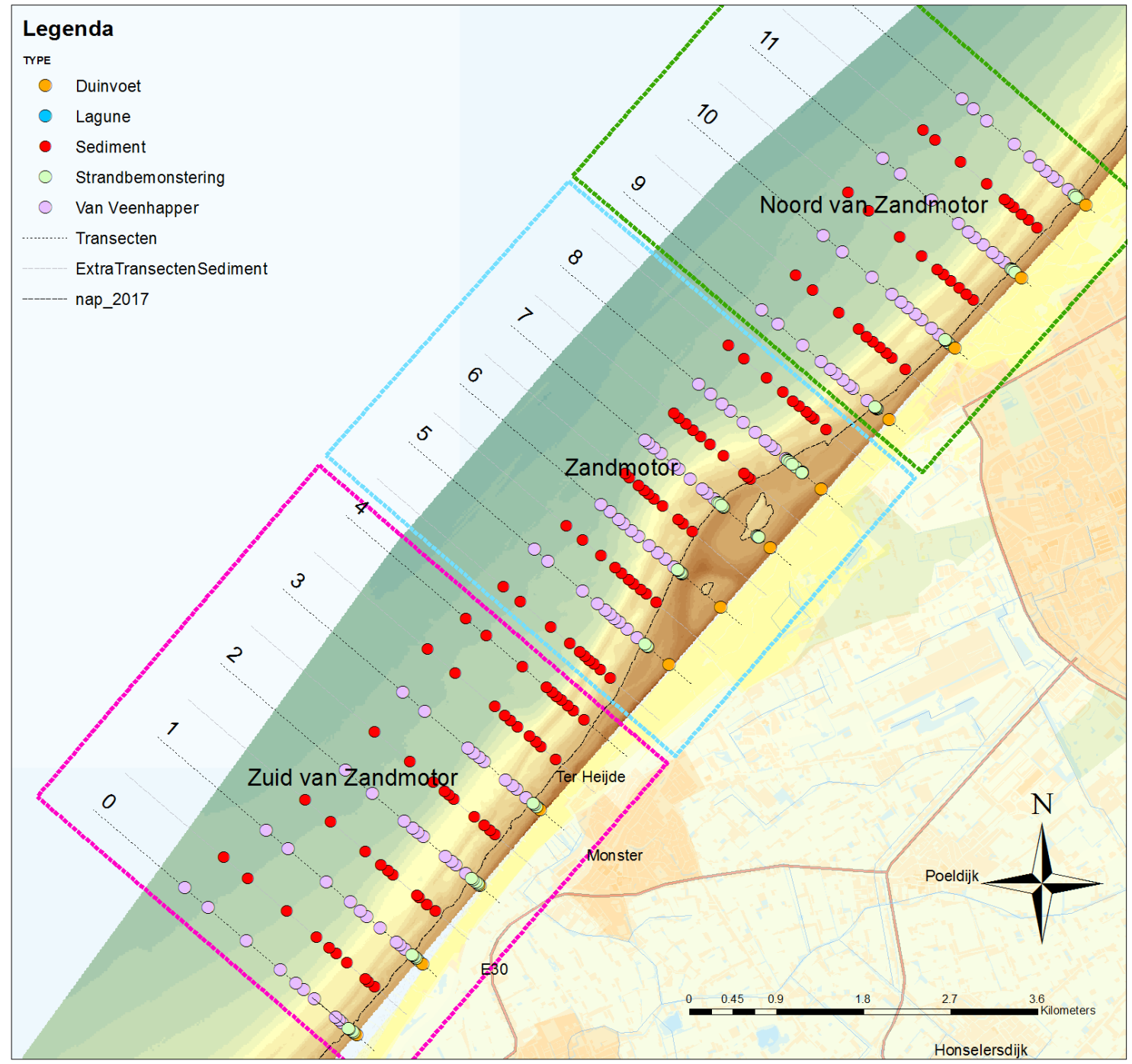

Figuur 1: Overzicht van de meetlocaties voor sediment en benthos bemonstering in het najaar van 2017. De roze locaties zijn bemonsterd met de Van Veen happer en de bodemschaaf. De groene locaties lagen op het strand en zijn bemonsterd met het steekframe en op de oranje (Duinvoet) en rode locaties is uitsluitend sediment verzameld. De monsterlocaties zijn geprojecteerd op een recente dieptekaart, waarbij het gebied van de Zandmotor is gemeten in juli 2017. De gekleurde gestippelde kaders geven de deelgebieden weer (Zuid van Zandmotor, Zandmotor en Noord van Zandmotor).

De monitoringslocaties die in het najaar van 2017 zijn bemonsterd voor het macrobenthos liggen op 12 transecten loodrecht op de voormalige kustlijn (Figuur 1). De ligging van deze transecten is vrijwel identiek aan de ligging van de transecten uit de bemonstering van 2010 (Wijsman en Verduin, 2011), 2012 (Wijsman, 2014a) en 2013 (Wijsman, 2014b). Het verschil is dat er vanaf 2013 een extra transect (transect 0 ) is bemonsterd aan de zuidwestzijde van het gebied. Dit is ten koste gegaan van de benthos bemonstering op transect 4. De reden om dit transect te verplaatsen, is dat er redelijk wat aanzanding is opgetreden op transect 4 door de aanleg van de Zandmotor waardoor dit transect niet meer kan worden beschouwd als een referentietransect. Het nieuwe transect 0 ligt 1000 meter verder van de Zandmotor vandaan waardoor de stations op dit transect minder zullen worden beïnvloedt door de Zandmotor. Tussen de benthos transecten zijn ook nog additionele transecten gelegen (0-a, 1-a, 2a enz.). De bemonsterde stations op deze transecten zijn aangegeven met rode stippen in Figuur 1. Op deze additionele transecten is alleen een bodemmonster verzameld voor sedimentanalyse en is geen benthos verzameld. Transecten 0 tot en met 4 liggen in het gebied ten zuiden van de Zandmotor. De onderlinge afstand tussen de transecten is 1000 meter. Transecten 5 tot en met 8 liggen in het gebied van de Zandmotor. De onderlinge afstand tussen deze transecten is 800 meter. 
Transecten 9 tot en met 12 liggen in het invloedgebied van de Zandmotor, ten noorden van de Zandhaak. De onderlinge afstand tussen deze transecten is 1000 meter.

In 2011, direct na de aanleg van Zandmotor, is er ook een bemonstering van de bodemdiergemeenschap uitgevoerd (Boon en Wijsman, 2012). In dat jaar is er gekozen voor een andere bemonsteringsopzet van de bodemdiergemeenschap, waarbij de transecten loodrecht op de Zandmotor zijn gelegd. Wegens de werkzaamheden zijn op de raaien 1, 2 en 3 slechts 3 van de 10 stations per raai bemonsterd met de Van Veen happer. Om budgettaire redenen zijn in 2011 slechts de helft van de bemonsterde stations uitgezocht. Bemonstering met de bodemschaaf heeft in 2011 helemaal niet plaatsgevonden. In het vergelijk tussen de jaren is daarom 2011 buiten beschouwing gelaten in voorliggend rapport.

De monsterlocaties hebben ieder een unieke code die bestaat uit het jaar en volgnummer e.g. 2017_001. De locaties 2017_001 tot en met 2017_120 zijn de locaties in de vooroever waar zowel benthos als sediment is bemonsterd. De locaties 2017_121 tot en met 2017_180 en 2017_196 tot en met 2017_205 zijn de locaties op het strand waar zowel benthos als sediment is bemonsterd. Op de locaties 2017_215 tot en met 2017_344 in de vooroever en 2017_181 tot en met 2017_192 op het strand is alleen een sedimentmonster genomen.

\section{Monsterlocaties in de vooroever}

In de vooroever van ieder transect liggen 10 monsterlocaties die zijn bemonsterd met de Van Veen happer en met de bodemschaaf. Op het eerste transect (transect 0 ) liggen van het strand naar het diepe water de locaties 2017_001 tot en met 2017_010. Op het tweede transect (transect 1) liggen de locaties 2017_011 tot en met 2017_020, enzovoorts. De exacte ligging van de monsterlocaties op de transecten is bepaald aan de hand van een recente bathymetriekaart (juli 2017), waarbij rekening is gehouden met de diepteligging en de morfologie. In principe zijn de diepteklassen aangehouden zoals aangegeven in Tabel 1. Indien er een brekerbank aanwezig was op het transect zijn de bemonsterde locaties zo gekozen dat er een locatie ligt op de top van de brekerbank en een locatie in de trog aan de binnenkant van de brekerbank (Figuur 2 en Figuur 3). Indien er geen (duidelijke) brekerbank aanwezig was zijn de locaties gelegen op het snijpunt van de transecten met de dieptelijnen zoals aangegeven in Figuur 2.

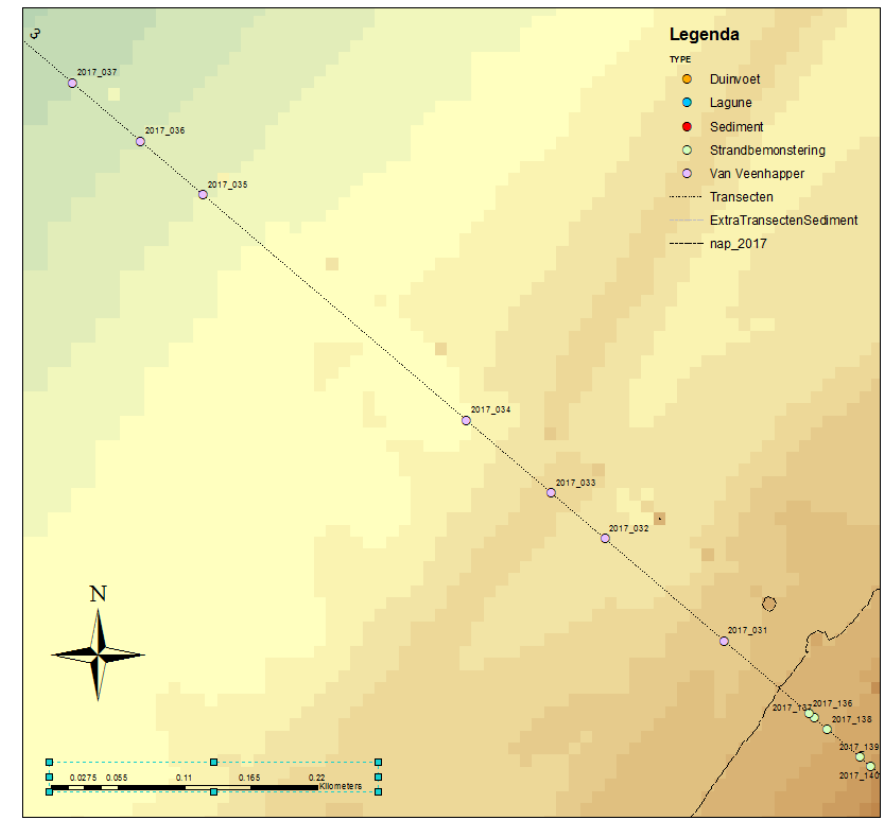

Figuur 2: Detailoverzicht van transect 3 uit de sediment en benthos bemonstering in het najaar van 2017. 


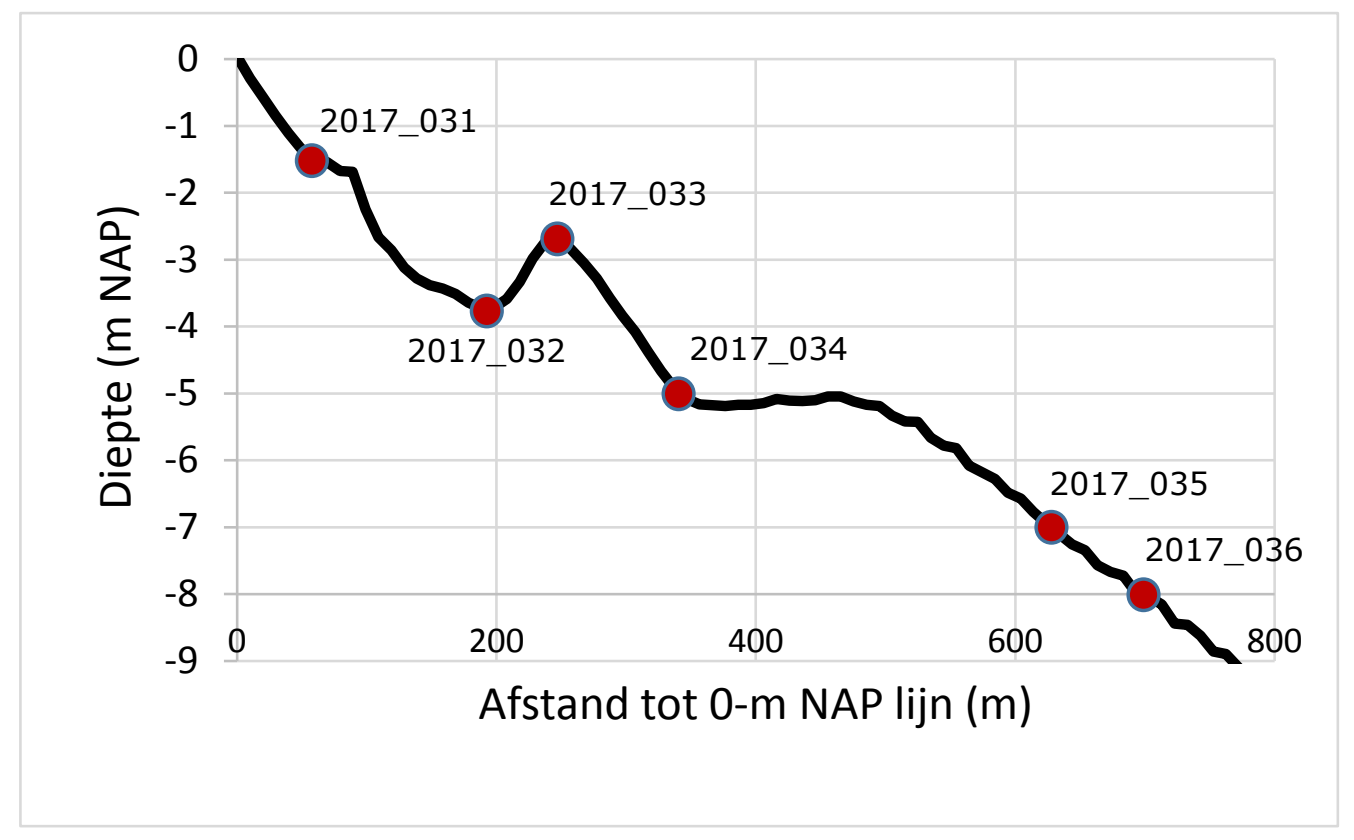

Figuur 3: Detailoverzicht van transect 3 uit de sediment en benthos bemonstering in het najaar van 2017.

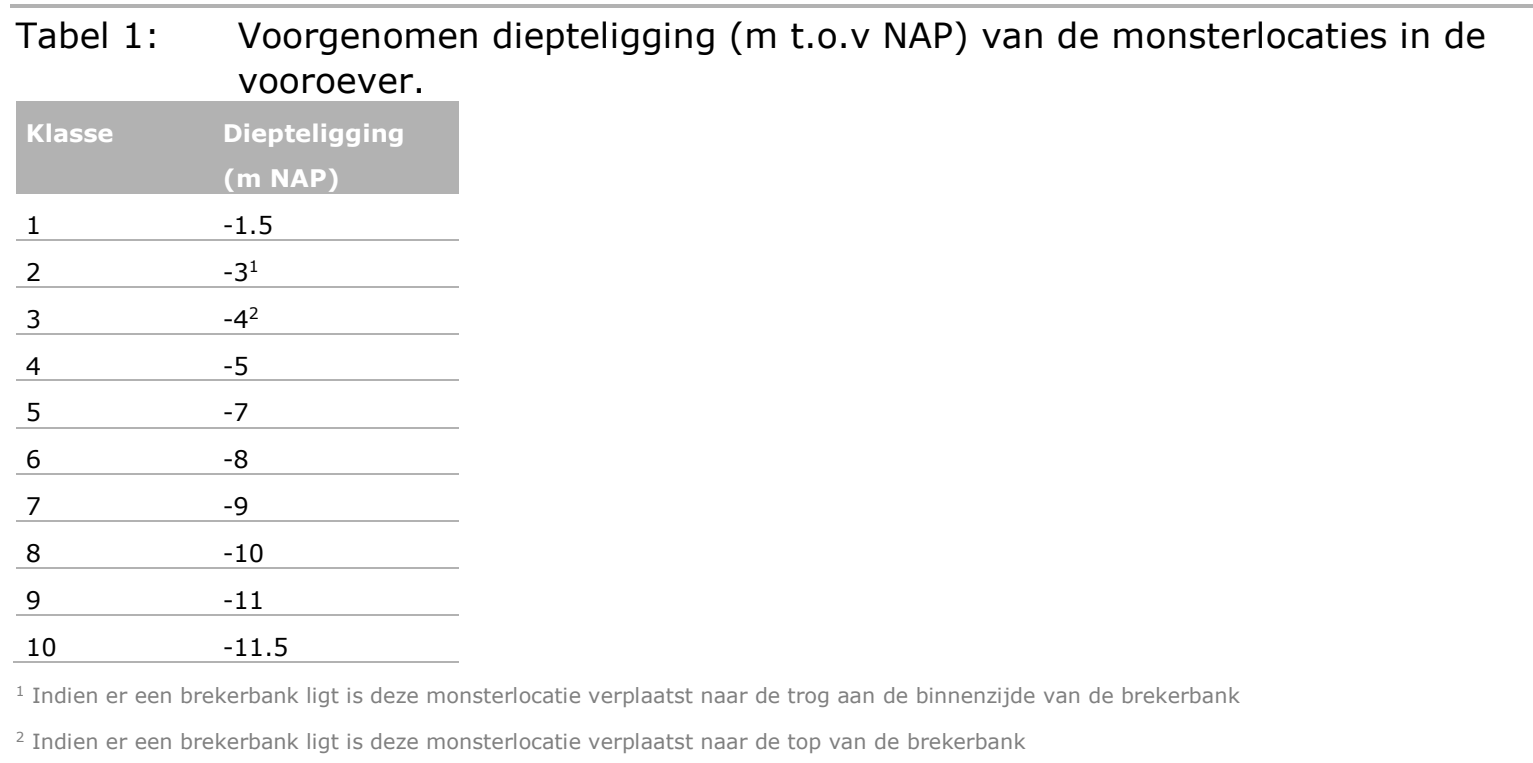

\section{Monsterlocaties op het strand}

Op het strand zijn telkens 5 monsterlocaties gelegen op dezelfde transecten. Op transect 0 liggen van de laagwaterlijn naar de hoogwaterlijn de locaties 2017_121 tot en met 2017_125. Op transect 1 liggen de locaties 2017_126 tot en met 2017_130, enzovoorts (Figuur 2). In het intergetijdengebied rond de lagune zijn twee aanvullende transecten bemonsterd. Op transect 8 zijn er aan de noordzijde van de lagune 5 stations bemonsterd (stations 2017_196 tot en met 2017_200). Op transect 7 zijn er aan de zuidzijde van de lagune 5 stations bemonsterd (stations 2017_201 tot en met 2017_205).

De exacte ligging van de monsterlocaties op het strand is afhankelijk van het getij. Bij Scheveningen is de tijd tussen hoogwater en laagwater ongeveer 5 uur (Figuur 4). Het blijft dan ongeveer drie uur laag waarbij het water nog een klein beetje afneemt voordat de vloed weer opkomt. Om de droogvalduur van de locaties per droogvalduurklasse uniform te houden zijn er iedere 1:15 uur monsters van de te bemonsteren transecten verzameld. De coördinaten van de monsterlocaties op het strand zijn geregistreerd met een handheld GPS (Garmin GPS 60). 


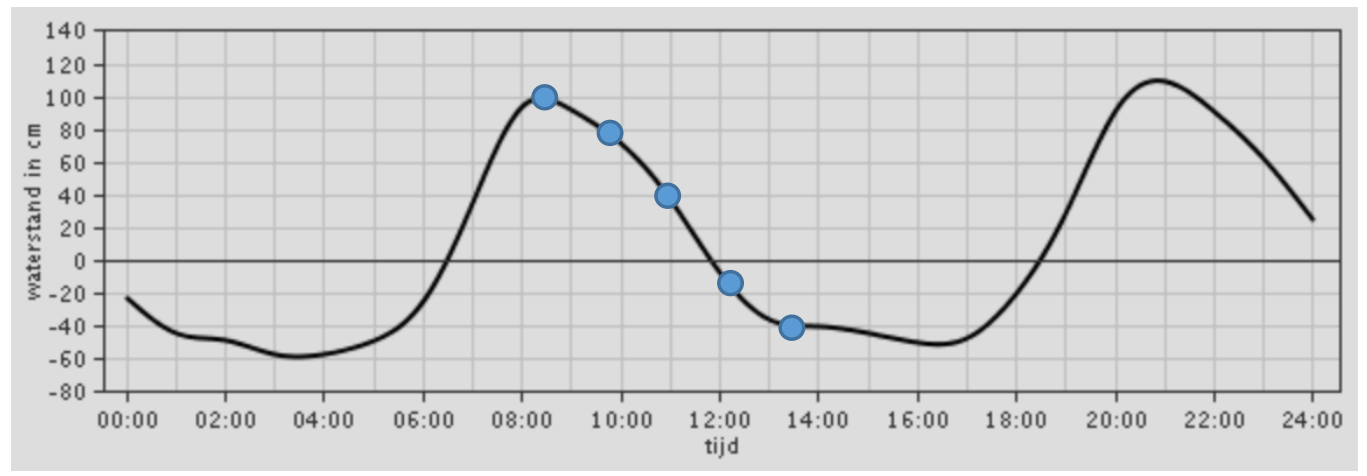

Figuur 4: Voorspelde getijcurve Scheveningen voor woensdag 11 oktober 2017. De blauwe stippen geven het moment van bemonstering weer.

Ten slotte is er op ieder transect ook nog een sedimentmonster genomen op de locatie waar het strand overgaat in het duin (Stationnummers 2017_181 tot en met 2017_192). Deze zijn door middel van oranje stippen aangegeven in Figuur 1.

\subsection{Weerscondities tijdens de bemonstering}

In Figuur 5 zijn de weerscondities voor het najaar van 2017 weergegeven. Deze gegevens zijn afkomstig van KNMI (locatie Hoek van Holland) en Windguru (www.windguru.cz.nl locatie Ter Heijde). Deze gegevens zijn indicatief voor de werkelijk opgetreden weersomstandigheden bij de Zandmotor. De maand augustus was relatief rustig met weinig wind. Begin september is het stevig gaan waaien uit het zuidwesten waardoor er golven van meer dan 2 meter zijn opgetreden. Aan het eind van september was het weer rustig waarbij de wind is gedraaid naar het oosten. Begin oktober toen de bemonstering net was gestart is het weer hard gaan waaien uit het noordwesten waardoor de bemonstering is uitgesteld en is afgerond in de dagen met relatief weinig golven.

De overheersende windrichting bij Ter Heijde in de periode 2010 tot en met 2017 was uit het zuidwesten (Figuur 6). In het najaar van 2017 (tussen 1 augustus en 1 november) kwam de overheersende windrichting overeen met de langjarig gemiddelde windrichting. 


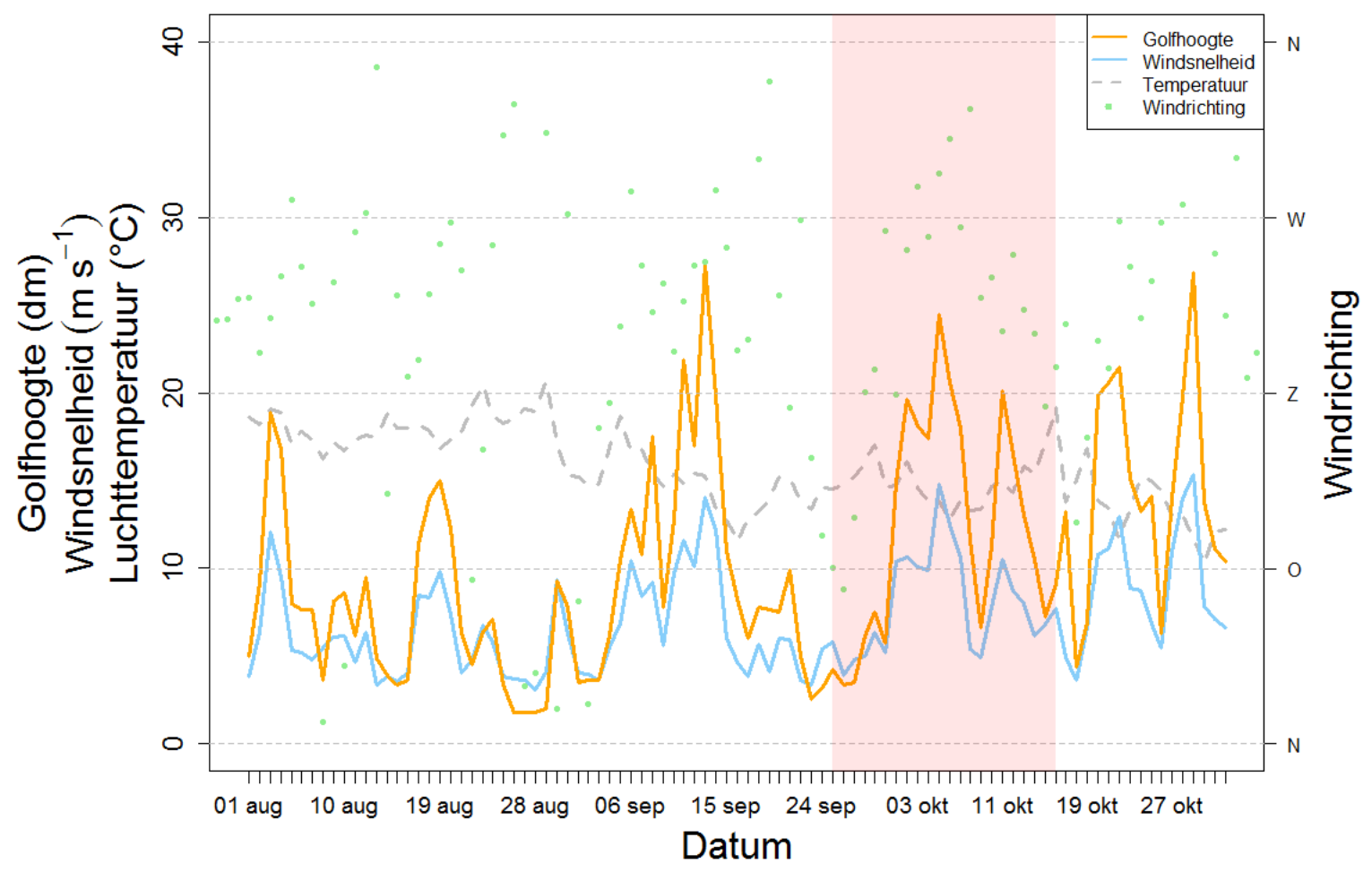

Figuur 5: Overzicht weersgegevens (Hoek van Holland) en golfhoogte (Ter Heijde) in de periode tussen 1 augustus en 1 november 2017. De oranje lijnen geven de daggemiddelde golfhoogtes $(\mathrm{dm})$, de blauwe lijn de daggemiddelde windsnelheid ( $\mathrm{m}$ $\mathrm{s}^{-1}$ ) en de gebroken grijze lijn de luchttemperatuur $\left({ }^{\circ} \mathrm{C}\right)$. De groene stippen geven de daggemiddelde windrichting aan. De bemonsteringsperiode is aangegeven door het oranje vlak. Data zijn afkomstig van KNMI (wind en temperatuur) en windguru.cz (golfhoogte).
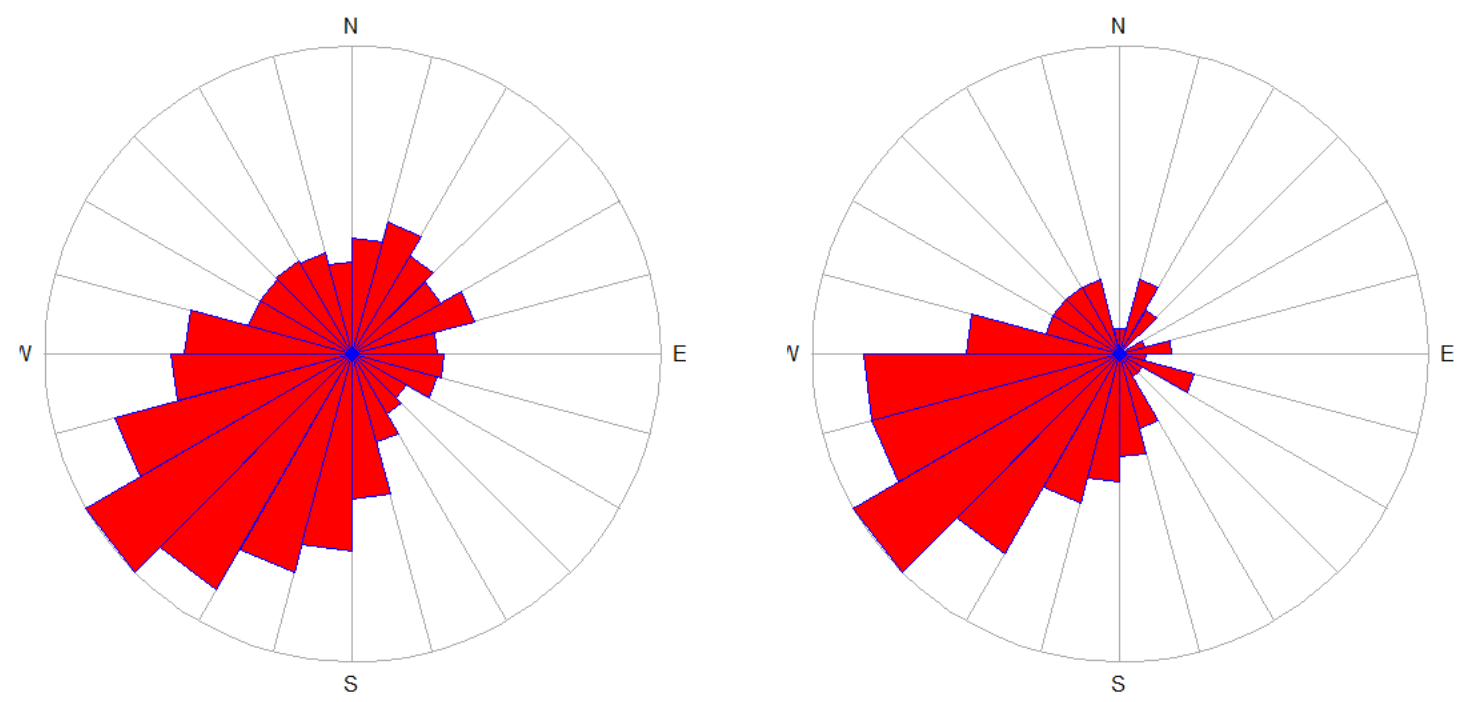

Figuur 6: Windroos voor de locatie Hoek van Holland voor de periode 1 jan 2010 tot en met 31 december 2017 (links) en voor het najaar (1 augustus tot en met 1 november) van 2017. Weergegeven is het aantal dagen dat de wind uit een bepaalde hoek kwam. Het maximaal aantal dagen is respectievelijk 269 en 12 dagen voor de linker en rechter figuur. 


\subsection{Sedimentsamenstelling}

In de periode van 28 september tot en met 16 oktober 2017 zijn in totaal 330 sedimentmonsters genomen voor de analyse van de korrelgrootteverdeling. Van 202 van deze stations is tevens het organisch stofgehalte (fractie organisch koolstof en totaal stikstof) bepaald. 248 locaties zijn bemonsterd in de ondiepe kustzone, 70 locaties op het strand en 12 locaties aan de rand van de duinvoet. Op de locaties 2017_220 (vistuig van een staandwantvisser) en 2017_295 (te ondiep) was het niet mogelijk om een sedimentmonster te nemen. In de ondiepe kustzone is een steekbuis ( $\varnothing 3$ $\mathrm{cm}$ ) vijf $\mathrm{cm}$ diep in het verzamelde sediment van de Van Veen happer gestoken. Op het strand is er een sedimentmonster genomen direct naast het steekframe. Gedurende de bemonstering zijn de sedimentmonsters bewaard in een koelbox en vervolgens in het laboratorium opgeslagen bij $-32{ }^{\circ} \mathrm{C}$.

Alle 330 monsters zijn gevriesdroogd en vervolgens is een subsample geanalyseerd op de korrelgrootteverdeling. De korrelgrootteverdeling is geanalyseerd middels laser diffractie met een Malvern Mastersizer (detectie range $0.02-2000 \mu \mathrm{m}$ ), op het laboratorium van het NIOZ in Yerseke. Het sediment is hierbij niet voorbehandeld. De korrelgrootteverdeling is geclassificeerd in 5 verschillende fracties (Tabel 2 ) volgens Wentworth (1922) en de mediane korrelgrootte $(\mu \mathrm{m})$ is berekend.

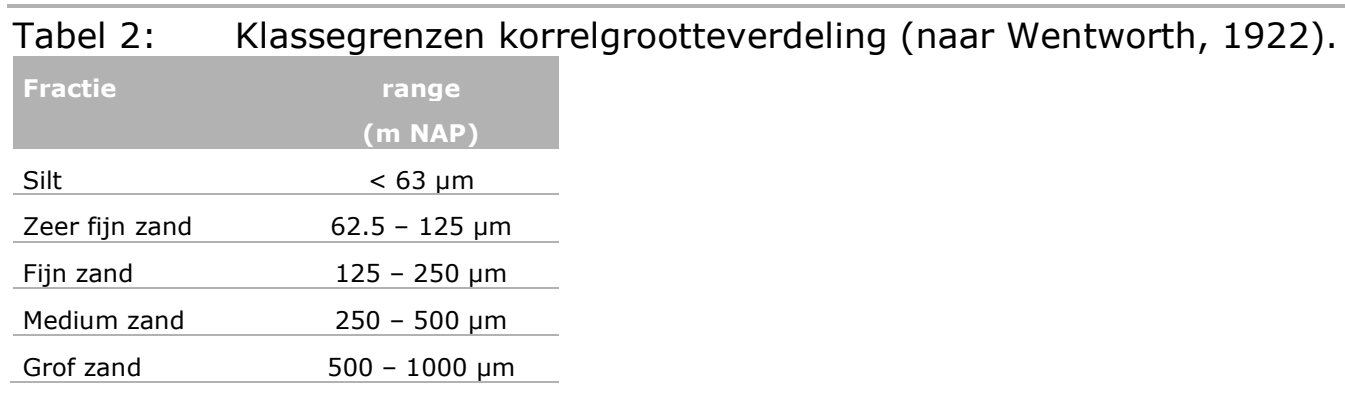

Een deel (202) van de monsters is tevens geanalyseerd op organisch stofgehalte (total $\mathrm{N}$ en Org C) met een Carlo Erba elemental analyzer, type NA-1500. Als voorbehandeling is het monster na vriesdrogen gemaald. De analyses zijn uitgevoerd door het NIOZ in Yerseke. Van de extra stations (rode stippen in Figuur 1) zijn geen organisch stofgehalten bepaald.

\section{$2.4 \quad$ Strand}

\subsubsection{Bemonstering}

De bemonstering van het strand is door Wageningen Marine Research uitgevoerd op woensdag 11 oktober 2017 (transecten 8 tot en met 12) en donderdag 12 oktober 2017 (transecten 0 tot en met 7)(Bijlage 2, Tabel 10). In totaal zijn er 70 locaties op het strand bemonsterd voor benthos. Er zijn twee transecten bemonsterd rond de lagune op de transecten 7 en 8 (Stations 2017_196 tot en met 2017_205). Tijdens de strandbemonstering zijn ook de (12) sedimentmonsters aan de duinvoet verzameld. 
De locaties zijn bezocht met een 4WD tijdens afgaand water. Op 11 september was het voorspelde hoogwater bij Scheveningen om 7:29 (116 cm NAP) en laagwater om 15:35 (-53 cm NAP). Op 12 september was het hoogwater om 8:25 (100 cm NAP) en laagwater om 16:25 (-52 cm NAP). Zodra de locatie droog kwam te staan is er een rvs frame $\left(37 \times 27 \mathrm{~cm} \approx 0,1 \mathrm{~m}^{2}\right)$ de bodem ingedrukt tot een diepte van $13 \mathrm{~cm}$ (Figuur 7). Met een spade is de inhoud van het frame leeggeschept en in emmers overgebracht. De inhoud van de emmers is vervolgens gezeefd over een $1 \mathrm{~mm}$ zeef. Het residu dat op de zeef is achtergebleven is overgebracht in potten $(500 \mathrm{ml})$ en geconserveerd in zeewater gebufferde formaline (4\%).

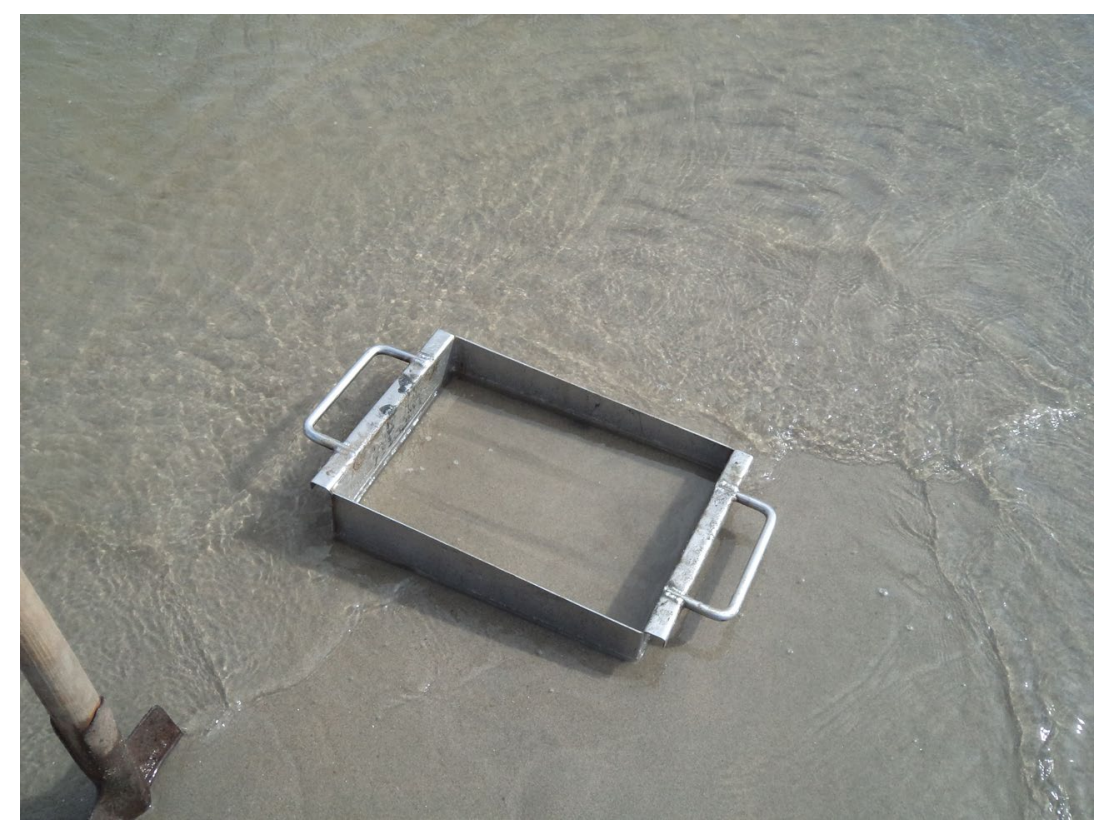

Figuur 7: RVS frame voor strandbemonstering. NB op de foto is er water in het frame gestroomd. Tijdens de bemonstering zou deze opnieuw worden gestoken om te voorkomen dat bijvoorbeeld amphipoden weg kunnen zwemmen.

\subsubsection{Verwerking}

De verwerking van de benthosmonsters van het strand was identiek aan de verwerking van de Van Veen monsters. Een beschrijving is te vinden in paragraaf 2.6.2.

\subsection{Bodemschaaf}

\subsubsection{Bemonstering}

De bemonstering met de bodemschaaf is door Wageningen Marine Research uitgevoerd met de Ye-42 in de periode van 25 tot en met 28 september 2017. De bodemschaaf wordt gebruikt voor een kwantitatieve bemonstering van de grotere en relatief zeldzame epibenthos en endobenthos soorten. De bodemschaaf is een kooi (maaswijdte $0,5 \mathrm{~cm}$ ) die aan de onderzijde is voorzien van een mes van $10 \mathrm{~cm}$ breed (Figuur 8). Het mes is ontworpen om een strip sediment over een bepaalde afstand tot een diepte van $10 \mathrm{~cm}$ weg te halen en in de kooi te brengen. Omdat het voorste deel iets boven de bodem hangt worden ook epibenthische organismen gevangen. Bepaalde vissen worden ook gevangen in de bodemschaaf (b.v. zandspiering), maar voor een kwantitatieve bemonstering van de vispopulaties zijn andere methodieken (bijvoorbeeld sleepnetten) meer geschikt. De kooi van de bodemschaaf fungeert tijdens het vissen als zeef. De bodemschaaf wordt achter een schip over de zeebodem getrokken. De beviste afstand wordt bepaald via een aan de zijkant van de bodemschaaf gemonteerd wiel (diameter 1,5 meter) voorzien van een elektronische teller die het aantal omwentelingen van het wiel registreert (Figuur 8). 


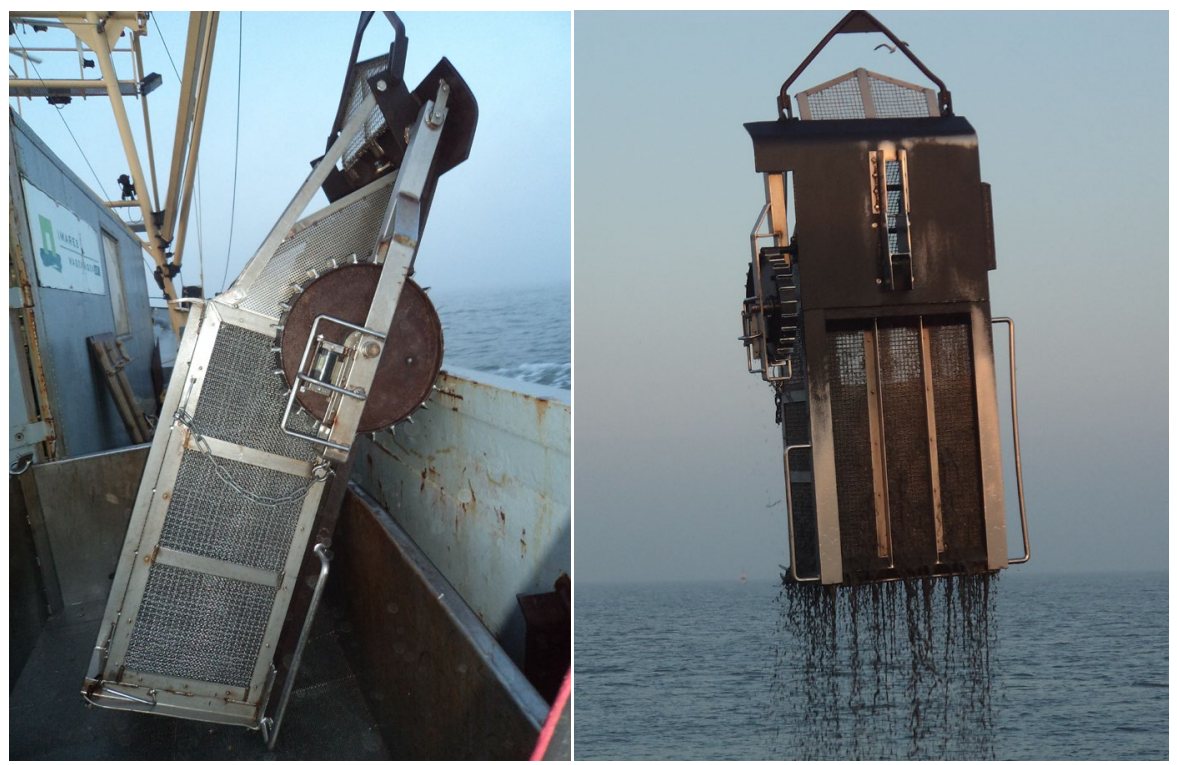

Figuur 8: $\quad$ Bodemschaaf. Links de bodemschaaf voordat deze overbood wordt gezet. Goed te zien is het wiel en de teller om het aantal omwentelingen te registreren waardoor de sleepafstand is te bepalen. Rechts is een gevulde bodemschaaf, voor driekwart gevuld met ruw monster. Het mes is op deze foto goed te zien.

Om te zorgen voor een goed bodemcontact is er een gewicht ( $280 \mathrm{~kg}$ ) geplaatst in het voorste deel van de bodemschaaf waar het mes zich bevindt. Het scharnier tussen dit voorste deel en de kooi is vastgezet. Om te voorkomen dat het wiel ronddraaide terwijl de bodemschaaf geen bodemcontact heeft, is een verstelbare blokkeerinrichting aangebracht. De valdiepte waarbij het wiel (inclusief schoepen) nog juist vrij kan draaien is op $90 \mathrm{~mm}$ ten opzichte van de onderkant van de bodemschaaf gezet.

De beoogde treklengte bedroeg $150 \mathrm{~m}$, resulterend in een bemonsterd oppervlakte van $15 \mathrm{~m}^{2}$. Tevens werd het moment van het begin en einde van vieren en halen geregistreerd en de diepte en de kabellengte genoteerd. De DGPS-positie van het schip is vastgelegd via twee onafhankelijke DGPSontvangers: Fugro Seastar DGPS met externe correctie vanaf de ARFSAT satelliet $(20 \mathrm{~Hz})$ en, als reserve, een JRC DGPS $(1 \mathrm{~Hz})$.

Alle slepen zijn genomen evenwijdig aan de kust (Figuur 9.) Dit om verschillen in heterogeniteit als gevolg van een verandering in bathymetrie te beperken. Er is zoveel mogelijk gestreefd om over het vooraf bepaalde punt heen te slepen met de bodemschaaf. 


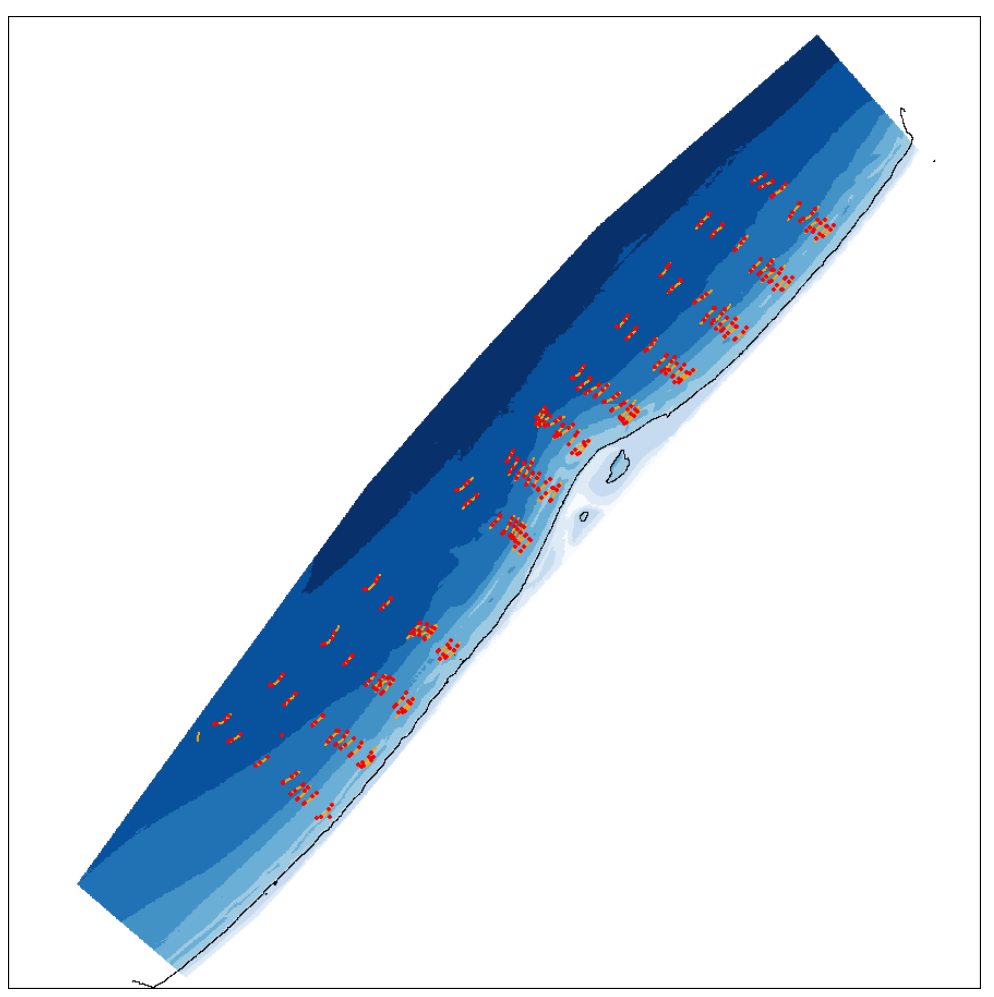

Figuur 9: Overzicht van de trekken met de bodemschaaf. De oranje lijn is de positie van het schip tijdens de sleep. De rode punten geven de momenten van begin vieren, eind vieren, begin halen en eind halen.

In verband met de ondiepte in combinatie met de golven was het niet mogelijk om alle stations te bemonsteren. In totaal konden 13 ondiepe stations (2017_001, 2017_002, 2017_011, 2017_021, 2017_031, 2017_041, 2017_051, 2017_061, 2017_071, 2017_081, 2017_091, 2017_101 en 2017_111) niet bemonsterd worden. De coördinaten van de bemonsterde stations zijn weergegeven in Bijlage 3, Tabel 11.

Ieder monster genomen met de bodemschaaf is in een bak, aan de onderzijde voorzien van gaas met een maaswijdte van $5 \mathrm{~mm}$ overgebracht en, indien noodzakelijk, is het monster gespoeld om het overtollige sediment te verwijderen. De vangst is nadien overgebracht in kisten van 48 liter of emmers van 10 liter.

\subsubsection{Verwerking}

Het totale volume van de vangst (liter) na het spoelen van het monster is genoteerd. Indien de vangst meer dan 6 liter was is er een subsample genomen van 6 liter welke in de container aan dek verder is gesorteerd en waar mogelijk tot op soort gedetermineerd.

Vervolgens is per soort het aantal individuen en het versgewicht (met uitzondering van de heremietkreeften (Diogenes pugilator en Pagurus bernhardus), en de otterschelp (Lutraria lutraria)). Het versgewicht is bepaald door weging op een zeeweegschaal van Marel M2000 series (weegvermogen: 0-300 gr (nauwkeurigheid $0.1 \mathrm{gr}$ ); 300-600 gr (0.2 gr); 600-1500 gr (0.5 gr)). Van otterschelpen (Lutraria lutraria), strandgapers (Mya arenaria) en zwaardschedes (Ensis spp.) worden door de bodemschaaf vaak alleen de siphonen bemonsterd. Van deze soorten konden daarom versgewicht niet direct worden bepaald.

Kapotte exemplaren van schelpdieren zijn meegeteld bij de bepaling van het aantal individuen indien a) het slot en vleesresten of b) enkel de sifons (bijv. zwaardschedes, otterschelpen) aanwezig zijn. Alle hele exemplaren van schelpdieren zijn per soort samen gewogen. Aantallen van krabben, slangsterren en zeesterren zijn bepaald aan de hand van respectievelijk het aantal carapaxen, het 
aantal schijven en het aantal armen ( $1 \mathrm{arm}=0.2$ individuen). De kapotte exemplaren en delen zijn ook gewogen. De breedte van schelpen van zwaardschedes is zoveel mogelijk aan boord gemeten om via regressie de versgewichten te bepalen (Craeymeersch et al., 2006).

Volledige exemplaren van vissen en garnalen zijn per individu gewogen. Tevens is per individu de lengte gemeten. Van kapotte exemplaren van vissen en garnalen zijn de koppen geteld, en meegeteld bij de bepaling van het aantal individuen. Alle restanten (incl. koppen) per soort zijn gezamenlijk gewogen (versgewicht). Niet te identificeren visresten zijn gezamenlijk gewogen.

Alle gegevens m.b.t. de aantallen en de versgewichten per soort, evenals de gemeten breedtes van zwaardschedes, zijn direct aan boord ingevoerd in een database. De gegevens m.b.t tellerstand en vangstvolumes zijn eerst aan dek genoteerd en op een later tijdstip in de invoerdatabase overgenomen.

Met de bodemschaaf worden naast schelpdieren, stekelhuidigen en anemonen ook een aantal mobiele vissen en garnalen gevangen. De bodemschaaf is niet ontwikkeld voor de bemonstering van deze mobiele soorten. In de verdere analyses zijn dan ook de vissen, de inktvissen en ook de garnalen buiten beschouwing gelaten. De vangstgegevens zijn wel ingevoerd in de database.

\subsection{Van Veen happer}

\subsubsection{Bemonstering}

De bemonstering van het macrozoöbenthos en het sediment in de ondiepe kustzone met de Van Veen bodemhapper is uitgevoerd met de Ye-42 en de ms Zuiderhaaks in de periode van 28 september 2017 tot en met 9 oktober 2017. Alle beoogde 120 stations zijn in deze periode bemonsterd. In 2017 zijn er in tegenstelling met 2013 en 2015 geen benthosmonsters genomen met de Van Veen happer in de lagune. De coördinaten van de bemonsterde stations zijn weergegeven in Bijlage 1, Tabel 9.

De bemonstering is uitgevoerd met een verzwaarde Van Veen bodemhapper, met een oppervlakte van $0,1 \mathrm{~m}^{2}$. Op iedere locatie is één monster genomen. Wanneer de Van Veen bodemhapper niet vol zat is het monster afgekeurd en is er een nieuw monster genomen.

De totale inhoud van de Van Veen bodemhapper is gezeefd over een $1 \mathrm{~mm}$ zeef en gefixeerd op zeewater gebufferde formaldehyde (4\%). De monsters zijn gecodeerd en opgeslagen.

\subsubsection{Verwerking}

Alle benthosmonsters die zijn verzameld met de Van Veen bodemhapper in de vooroever alsmede de benthosmonsters die zijn verzameld op het strand zijn uitgezocht en de aangetroffen exemplaren zijn (indien mogelijk) tot op soort gebracht door taxonomen van Wageningen Marine Research (50\% van de monsters) en het consortium Eurofins Aquasense/Bureau Waardenburg (overige 50\% van de monsters). Alle monsters die door Eurofins Aquasense/Bureau Waardenburg zijn geanalyseerd zijn door Wageningen Marine Research nagelopen, en waar nodig gecorrigeerd alvorens deze zijn verast.

Per locatie per soort is het asvrijdrooggewicht (AFDW) bepaald met een PrepAsh. Deze verassingsoven kan 12 tot maximaal 29 monsters (afhankelijk van de grootte van het monster) in een run analyseren. Tijdens het drogen en het verassen wordt het gewicht van het monster continu gemonitord. Wanneer de gewichten van de monsters tijdens het drogen respectievelijk verassen niet meer veranderen $(<$ $0.1 \%$ per 30 minuten) is de betreffende fase afgerond. Het drogen is uitgevoerd bij $100^{\circ} \mathrm{C}$ en het verassen bij $520^{\circ} \mathrm{C}$. AFDW is bepaald uit het verschil tussen het drooggewicht en het gewicht na verassing.

Om de verschillen tussen de labs en effecten van veranderingen in naamgevingen te verminderen zijn de namen van een aantal taxa aangepast voordat de analyses zijn uitgevoerd (Tabel 3). 
Tabel 3: Correcties namen Van Veen en Strandbemonstering.

\begin{tabular}{|c|c|}
\hline Oorspronkelijke naam & Gebruikte naam \\
\hline Abra spp. & Abra alba \\
\hline Aphelochaeta marioni & Cirratulidae \\
\hline Capitella capitata & Capitella spp. \\
\hline Capitellidae & Capitella spp. \\
\hline Echinocardium spp. & Echinocardium cordatum \\
\hline Ensis leei & Ensis spp. \\
\hline Eteone longa & Eteone spp. \\
\hline Eteone flava & Eteone spp. \\
\hline Eteoninae & Eteone spp. \\
\hline Euspira spp. & Euspira nitida \\
\hline Fabulina spp. & Fabulina fabula \\
\hline Grania spp. & Grania postclitellochaeta \\
\hline Harmothoe imbricata & Harmothoe spp. \\
\hline Harmothoe impar & Harmothoe spp. \\
\hline Jaera spp. & Jaera (Jaera) albifrons \\
\hline Lanice spp. & Lanice conchilega \\
\hline Liocarcinus spp. & Liocarcinus holsatus \\
\hline Lutraria spp. & Lutraria lutraria \\
\hline Malmgreniella spp. & Malmgrenia spp. \\
\hline Marenzelleria spp. & Marenzelleria viridis \\
\hline Melita spp. & Melitidae \\
\hline Microprotopus spp. & Microprotopus maculatus \\
\hline Owenia fusiformis & Owenia spp. \\
\hline Pectinaria spp. & Pectinariidae \\
\hline Polynoinae & Polynoidae \\
\hline Processa parva & Processa modica modica \\
\hline Pseudocuma (Pseudocuma) simile & Pseudocuma simile \\
\hline Scolelepis spp. & Scolelepis (Scolelepis) squamata \\
\hline Scoloplos spp. & Scoloplos armiger \\
\hline Sipunculus nudus & Sipuncula spp. \\
\hline Spio filicornis & Spio spp. \\
\hline Stenothoe spp. & Stenothoe marina \\
\hline Streblospio spp. & Streblospio benedicti \\
\hline Streblospio shrubsolii & Streblospio benedicti \\
\hline Tellina spp. & Tellinidae \\
\hline Tharyx spp. & Cirratulidae \\
\hline Urothoe spp. & Urothoe poseidonis \\
\hline Venerupis spp. & Venerupis corrugata \\
\hline
\end{tabular}

\subsection{Data analyse}

De bodemdiergegevens verzameld met de bodemschaaf en de Van Veen happer zijn afzonderlijk geanalyseerd met diverse univariate en multivariate technieken. Eventuele vissen, inktvissen, garnalen en insecten zijn in de analyses buiten beschouwing gelaten. Oligochaeten, Bryozoa, Hydrozoa, Anthozoa en Nemertea zijn samengevoegd tot op het niveau van Klasse of Phylum.

In de multivariate analyses over het jaar 2017 zijn taxa die slechts op één station zijn aangetroffen niet meegenomen in de analyses. In de analyses over alle jaren zijn alleen taxa meegenomen die vaker dan 5 keer zijn aangetroffen.

De multivariate analyses (cluster analyse en multi-dimensional scaling) zijn uitgevoerd op de dichtheden (aantal $\mathrm{m}^{-2}$ ) van de organismen met behulp van PRIMER (Clarke et al., 2014a; Clarke en Gorley, 2015). De data zijn vierdemachtswortel getransformeerd om ervoor te zorgen dat er een goede balans is tussen dominante soorten en minder abundante soorten in de variantieanalyses 
(Clarke et al., 2014b). De analyses zijn uitgevoerd op de Bray-Curtis similariteits matrix. De BrayCurtis similariteit $\left(S_{j k}\right)$ tussen twee locaties $(j$ en $k$ ) is daarbij berekend als:

$$
S_{j k}=100\left\{1-\frac{\sum_{i=1}^{p}\left|y_{i j}-y_{i k}\right|}{\sum_{i=1}^{p}\left|y_{i j}+y_{i k}\right|}\right\}
$$

Hierbij is $y_{i k}$ de dichtheid van soort $i$ op locatie $k$. Hoe hoger de waarde van de Bray-Curtis similariteit tussen twee locaties $j$ en $k$, hoe meer overeenkomsten tussen bodemdiergemeenschap die is gevonden op beide stations. De Bray-Curtis similariteit ligt tussen 0 (bodemdiersamenstelling is compleet anders) en 100 (zelfde soorten in dezelfde verhoudingen).

Een clusteranalyse groepeert de bemonsterde stations in groepen (clusters) op basis van de overeenkomsten in de bodemdiersamenstelling (Bray-Curtis similariteit). Stations binnen een cluster hebben dus een overeenkomstige bodemdiergemeenschap. De clusters zijn berekend op group averages en significantie van de clusters is getoetst met een SIMPROF permutatie test $(\alpha=0.05)$. Met behulp van deze test is het mogelijk om te toetsen of de verschillen in bodemdiersamenstelling tussen twee verschillende cluster gebaseerd zijn op toeval of niet.

Een andere manier om de verschillen in bodemdiergemeenschap tussen de stations te visualiseren is via multidimensional scaling (MDS). Bij een MDS worden de dissimilariteiten (100 - similariteit) gevisualiseerd in een twee-dimensionale figuur, waarbij de afstand tussen twee locaties op de figuur overeenkomt met de dissimilariteit in bodemdiersamenstelling tussen betreffende stations. Hoe dichter de stations dus bij elkaar liggen in een MDS plot, hoe meer overeenkomsten er zijn in bodemdiersamenstelling. Een nMDS is een niet-metrische MDS waarbij de afstand is gebaseerd op de rangorde van de dissimilariteiten. Om de ontwikkeling over de tijd in kaart te brengen zijn er aanvullende nMDS analyses uitgevoerd over geaggregeerde data (Jaar_Gebied en Jaar_Diepteklas). 


\section{Resultaten}

\subsection{Sediment}

\subsubsection{Korrelgrootteverdeling}

Er zijn een groot aantal sedimentkarakteristieken gemeten met de Malvern Particle Sizer (zie Bijlage 4). Veel van deze parameters zijn aan elkaar gerelateerd. In Figuur 10 zijn deze parameters tegen elkaar uitgezet, samen met de diepte waar het monster is genomen ( $\mathrm{cm}$ t.o.v. NAP). Uit de figuur is te zien dat veel van parameters sterk zijn gerelateerd aan de parameter mediane korrelgrootte. Daarom kan de mediane korrelgrootte worden gebruikt als proxy voor de overige parameters.

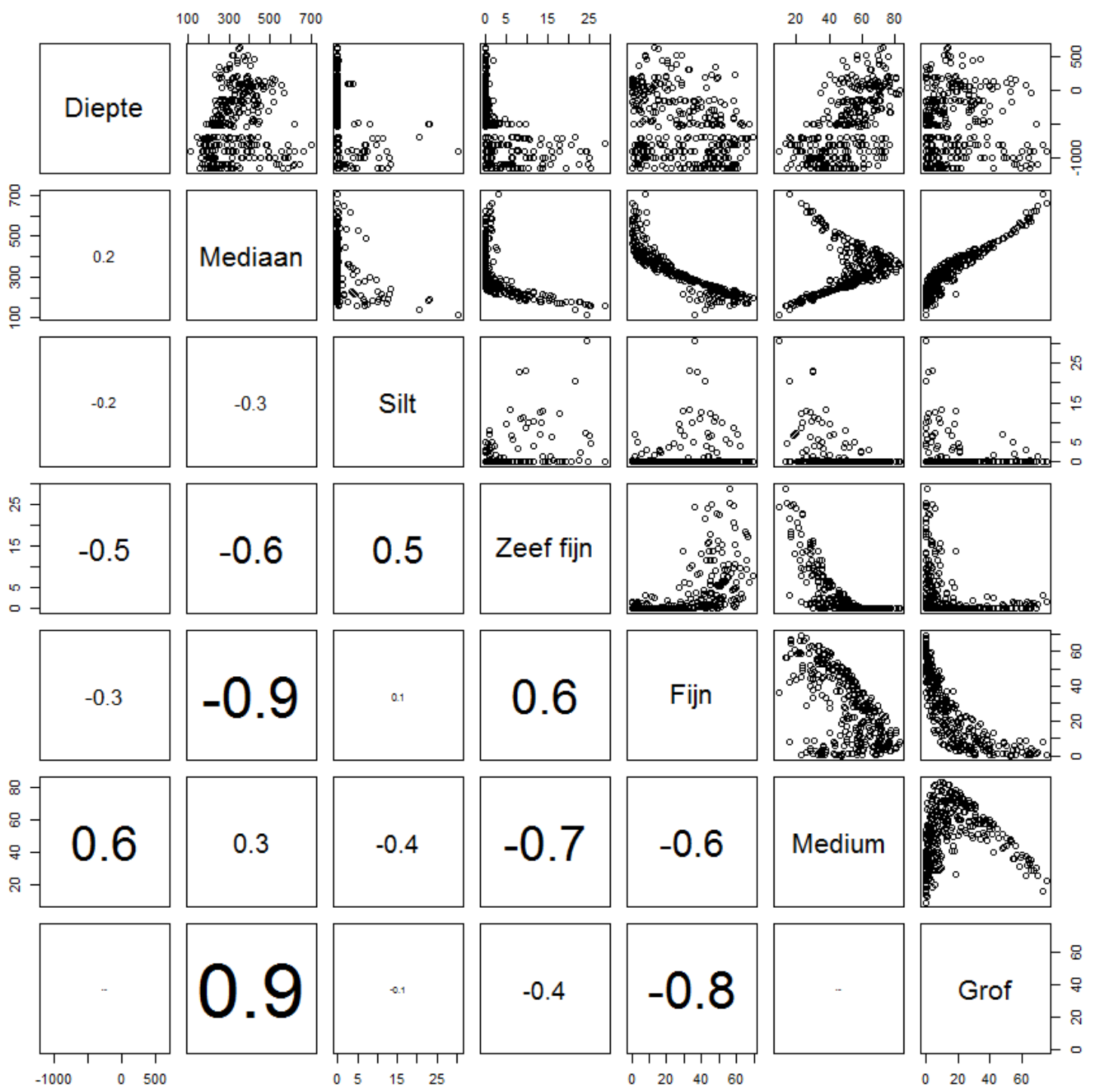

Figuur 10: Correlatiematrix tussen diepte ( $\mathrm{cm}$ t.o.v. NAP), mediane korrelgrootte $(\mu \mathrm{m})$ en percentages silt, zeer fijn zand, fijn zand, medium zand en grof zand in 2017 . Onder de diagonaal zijn de correlatiecoëfficiënten gegeven. 
De gemiddelde mediane korrelgrootte in 2017 was $329 \mu \mathrm{m}$ (st.dev. $109 \mu \mathrm{m}$ ). De kleinste mediane korrelgrootte $(113 \mu \mathrm{m})$ is gevonden op locatie 2017_087, iets ten noorden van de Zandmotor (transect 9) op een waterdiepte van ongeveer 8 meter, en de grootste mediane korrelgrootte (704 $\mu \mathrm{m}$ ) is gevonden op locatie 2017_340, op transect 11-a op een waterdiepte van ongeveer 9 meter.

Diepte is een belangrijke co-variabele voor de mediane korrelgrootte. Een GAM (Generalised Additive Model) is gefit door alle metingen op het strand en de vooroever. Een GAM model bestaat uit verschillende componenten: een link functie van de verklarende variabelen (in dit geval diepte), een systematische component (smoother) en een random component (variatie). De smoother kan variëren van een rechte lijn (aantal vrijheidsgraden $=1$ ) tot een interpolatie van alle datapunten (aantal vrijheidsgraden $=\mathrm{n}-1$ ). In deze studie is de er voor de waarde van de smoother parameter $\mathrm{k}=4$ gekozen. Bij de selectie van het beste model dient aan de ene kant het aantal vrijheidsgraden te worden geminimaliseerd en aan de andere kant dient de fit zo goed mogelijk te zijn. Deze optimalisatie wordt bereikt met behulp van een zogeheten "minimized gereralized cross validation".

Het GAM model van Figuur 11 is significant $(p<0.05)$ en geeft aan dat er een significant effect is van waterdiepte op de mediane korrelgrootte. Op het strand (tot ongeveer 1 meter beneden NAP is de mediane korrelgrootte het grootst. Daarna neemt de mediane korrelgrootte af tot een diepte van ongeveer 7 meter beneden NAP. Op grotere dieptes neemt de mediane korrelgrootte weer iets toe. De zwarte stippen in Figuur 11 zijn de gemiddelde waarde per diepteklasse (iedere meter ten opzichte van NAP).

In het ruimtelijke verspreidingsplaatje (Figuur 12) is wel te zien dat er rond de Zandmotor gebieden zijn met grovere en gebieden met fijnere sedimenten. Zo lijken de sedimenten zeewaarts op de kop van de Zandmotor (transecten 5 tot en met 8 ) grover dan op dezelfde diepte in de gebieden iets ten noorden (transecten 8-a en 9) en ten zuiden (transecten 4 en 4-a) van de Zandmotor. Ook is er een gebied met relatief grove sedimenten helemaal in het Noorden (transecten 11, 11-a en 12). In de diepere delen van het zuidelijk gebied (transecten 0, 0-a, 1 en 1-a) zijn juist fijne sedimenten te vinden.

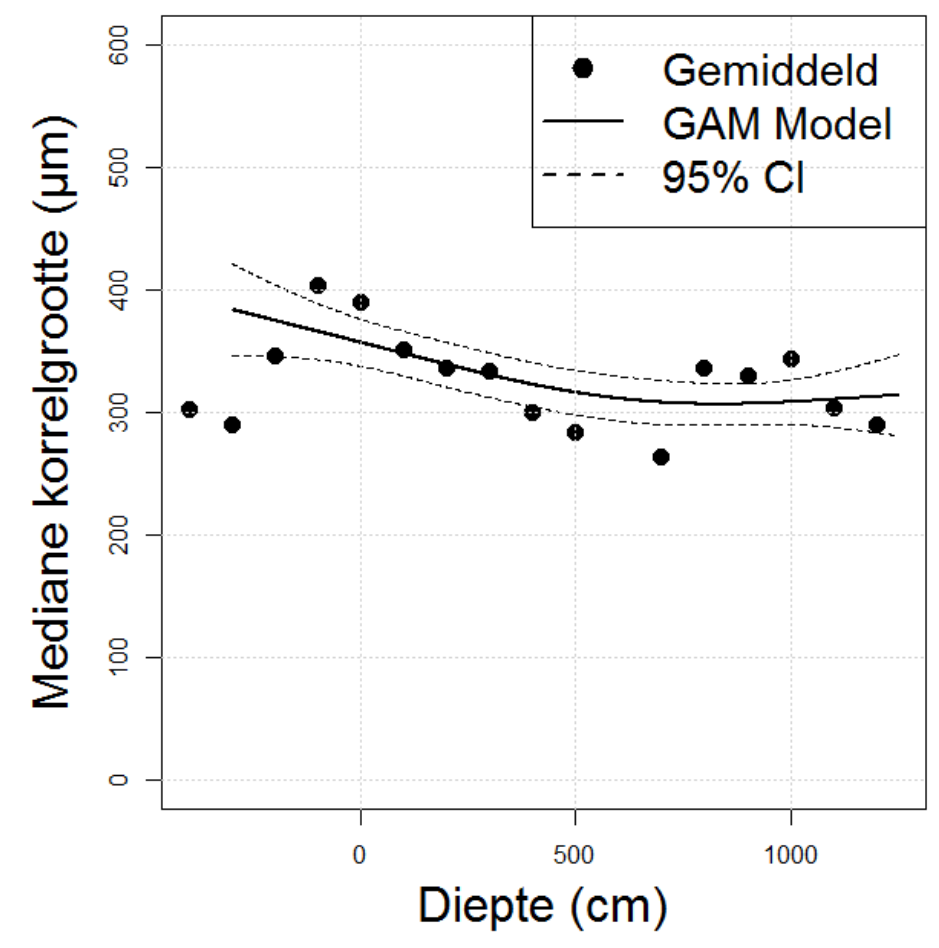

Figuur 11: Mediane korrelgrootte $(\mu \mathrm{m})$ als functie van de waterdiepte ( $\mathrm{cm}$ beneden NAP) voor de monsters die zijn verzameld op het strand en de vooroever. De getrokken lijn is de GAM-regressie en de gestippelde lijnen zijn de $95 \%$ betrouwbaarheidsintervallen. 


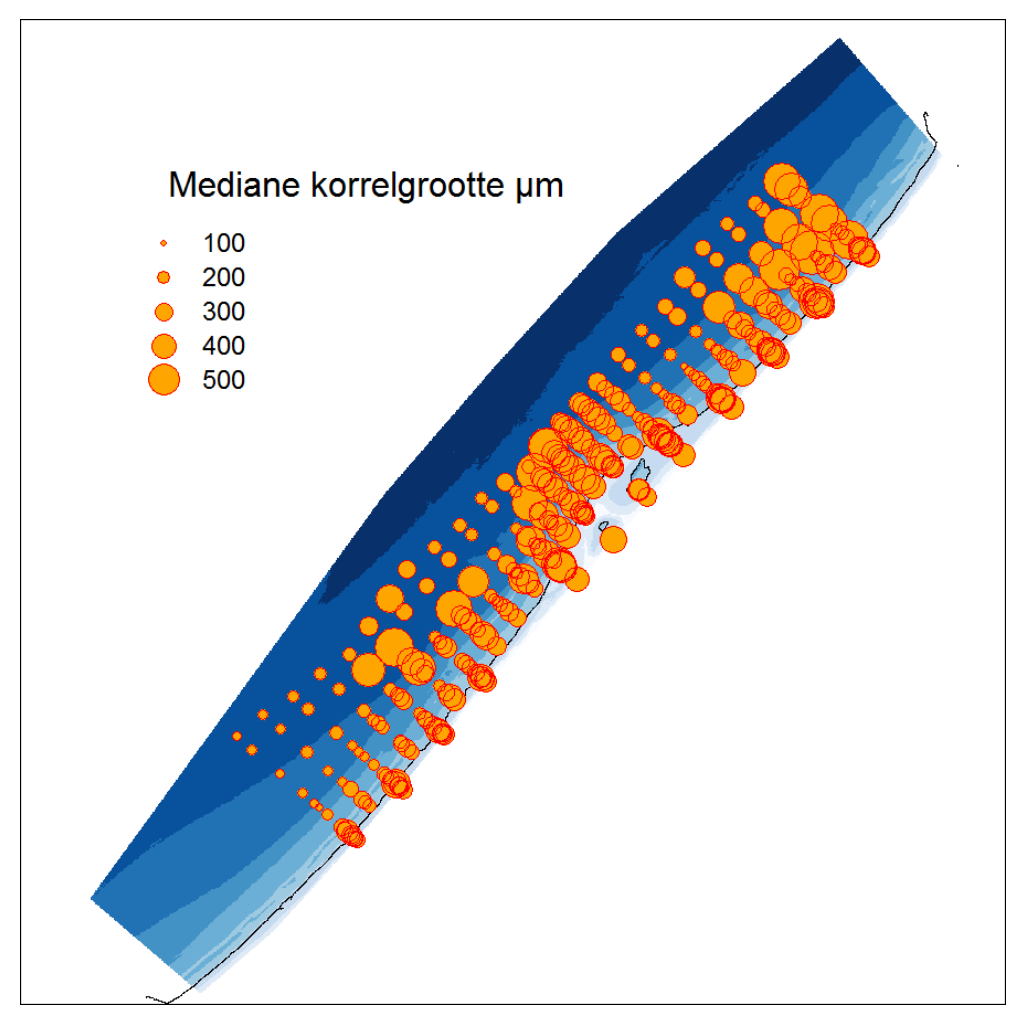

Figuur 12: Ruimtelijke verdeling mediane korrelgrootte $(\mu \mathrm{m})$ in het gebied van de Zandmotor.

In Figuur 13 is voor de verschillende transecten de relatie tussen mediane korrelgrootte en de waterdiepte weergegeven. Transecten 2, 3, 4, 7, 10 en 11 (en 12) vertonen geen duidelijke relatie met de diepte. Op de transecten $0,1,5,8$ en 9 neemt de mediane korrelgrootte af met de diepte. Op het strand is de mediane korrelgrootte vaak groter dan in de ondiepe vooroever. In de diepere delen (dieper dan 7 meter) is er dan een stabilisatie of een lichte stijging in de mediane korrelgrootte. Op transect 6 neemt de mediane korrelgrootte iets toe met de diepte. Dit komt deels door de relatief fijne monsters die zijn genomen op dit transect aan de zuidzijde van de lagune. Op transecten 11 (en 12) worden de grofste sedimenten echter gevonden op dieptes groter dan 7 meter beneden NAP. 

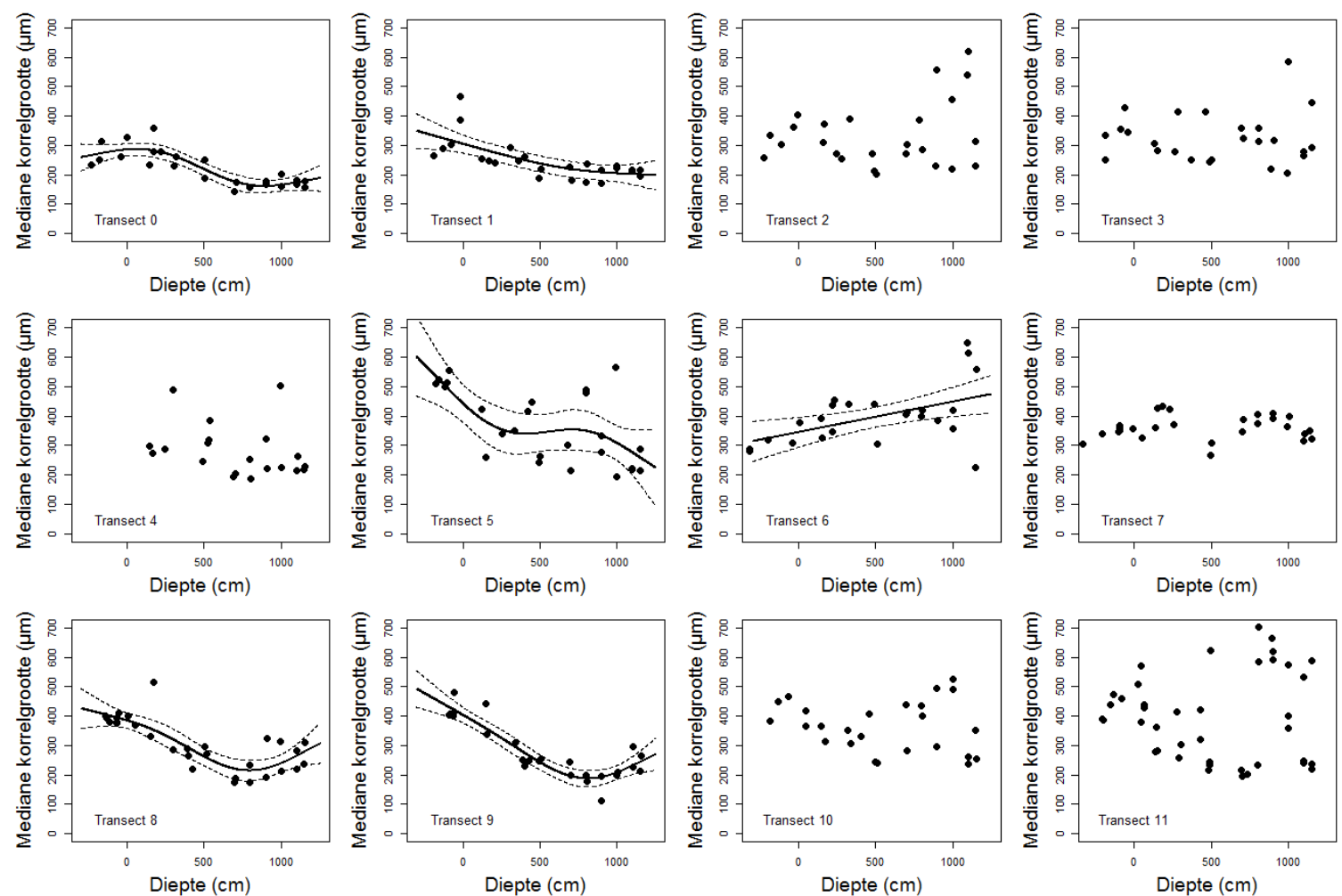

Figuur 13: Resultaat GAM analyses voor de mediane korrelgrootte $(\mu \mathrm{m})$ als functie van de diepteligging t.o.v. NAP voor de verschillende transecten. Iedere figuur bevat de gegevens van twee transecten, het transect zelf $(x)$ en het bijbehorende aanvullende transect voor sediment $(x-a)$. Alleen de figuur van transect 11 bevat de gegevens van drie transecten (transect 11, transect 11-a en transect 12). Alleen de significante $(p<0.05)$ GAM modellen zijn in de figuren geplot.

\subsubsection{Vergelijk voorgaande jaren}

In voorgaande jaren (2010, 2012, 2013 en 2015) zijn ook de sedimentkarakteristieken bepaald met dezelfde methode. Het aantal sedimentmonsters dat is geanalyseerd is niet in alle jaren gelijk (Tabel 4). In 2013 was het vanwege het weer niet mogelijk om een aantal ondiepe stations in de vooroever te bemonsteren. Vanaf 2013 zijn er naast de sedimentmonsters op de reguliere transecten ook nog een aantal (ca 13) monsters genomen op de tussengelegen transecten. Ook zijn er in 2013 en 2015 een aantal (slibrijke) monsters genomen in het sublitoraal deel van de lagune.

Tabel 4: Aantal sedimentmonsters dat is verzameld op en rond de Zandmotor in de verschillende jaren.

\begin{tabular}{|c|c|c|c|c|c|c|}
\hline Jaar & Vooroever & $\begin{array}{l}\text { Vooroever } \\
\text { aanvullend }^{1}\end{array}$ & Strand & Duinvoet & Lagune & Totaal \\
\hline 2010 & 61 & 0 & 60 & 12 & 0 & 133 \\
\hline 2012 & 120 & 0 & 65 & 12 & 0 & 197 \\
\hline 2013 & $97^{2}$ & 130 & 70 & 12 & 9 & 318 \\
\hline
\end{tabular}

${ }^{1}$ Vanaf 2013 zijn er aanvullende sedimentmonsters genomen op de extra transecten

${ }^{2}$ In 2013 zijn een aantal ondiepe stations in de vooroever niet bemonsterd vanwege slecht weer 
$\mathrm{Er}$ is geen duidelijke trend in de mediane korrelgrootte over de verschillende jaren (Figuur 14). De slibrijke monsters uit de lagune in de jaren 2013 en 2015 zijn hierbij buiten beschouwing gelaten. De mediane korrelgrootte in 2010 lijkt iets lager dan in de overige jaren, maar dit verschil is niet significant (anova, $\mathrm{p}>0.05$ ).

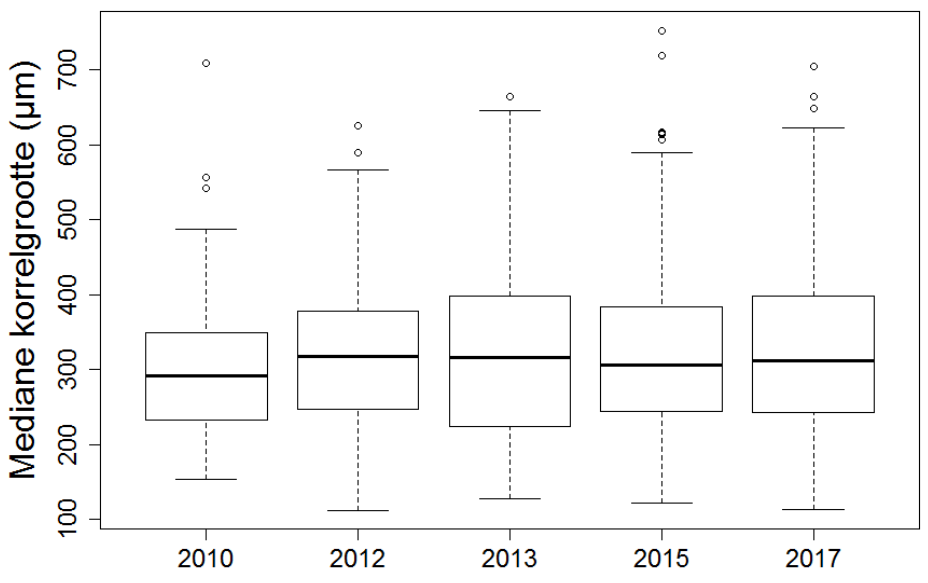

Figuur 14: Boxplots van de mediane korrelgrootte over de verschillende jaren. De slibrijke monsters uit de lagune in de jaren 2013 en 2015 zijn buiten beschouwing gelaten.

In Figuur 15 zijn de resultaten van de GAM regressies over de diepte voor de verschillende jaren weergegeven. Hoewel Figuur 13 liet zien dat er een grote variatie zit over de transecten geven de figuren over de jaren een gemiddeld patroon weer. Het jaar 2017 heeft een vergelijkbaar patroon als het jaar 2010. In 2012, 2013 en 2015 is er een duidelijkere afname in mediane korrelgrootte van het hoge deel van het strand naar de ondiepe vooroever (2-3 meter beneden NAP). In die jaren is er echter, vanwege de beperkte getijslag tijdens de bemonstering niet op de hoogste delen van het natte strand gemonsterd. In 2010 en 2017 blijkt dat daar de mediane korrelgrootte weer afneemt. In 2012 lijkt de mediane korrelgrootte weer toe te nemen in de diepere delen van de vooroever ( $>8$ meter beneden NAP). In 2017 is dit ook het geval in de transecten 8 en 9 (Figuur 13). 

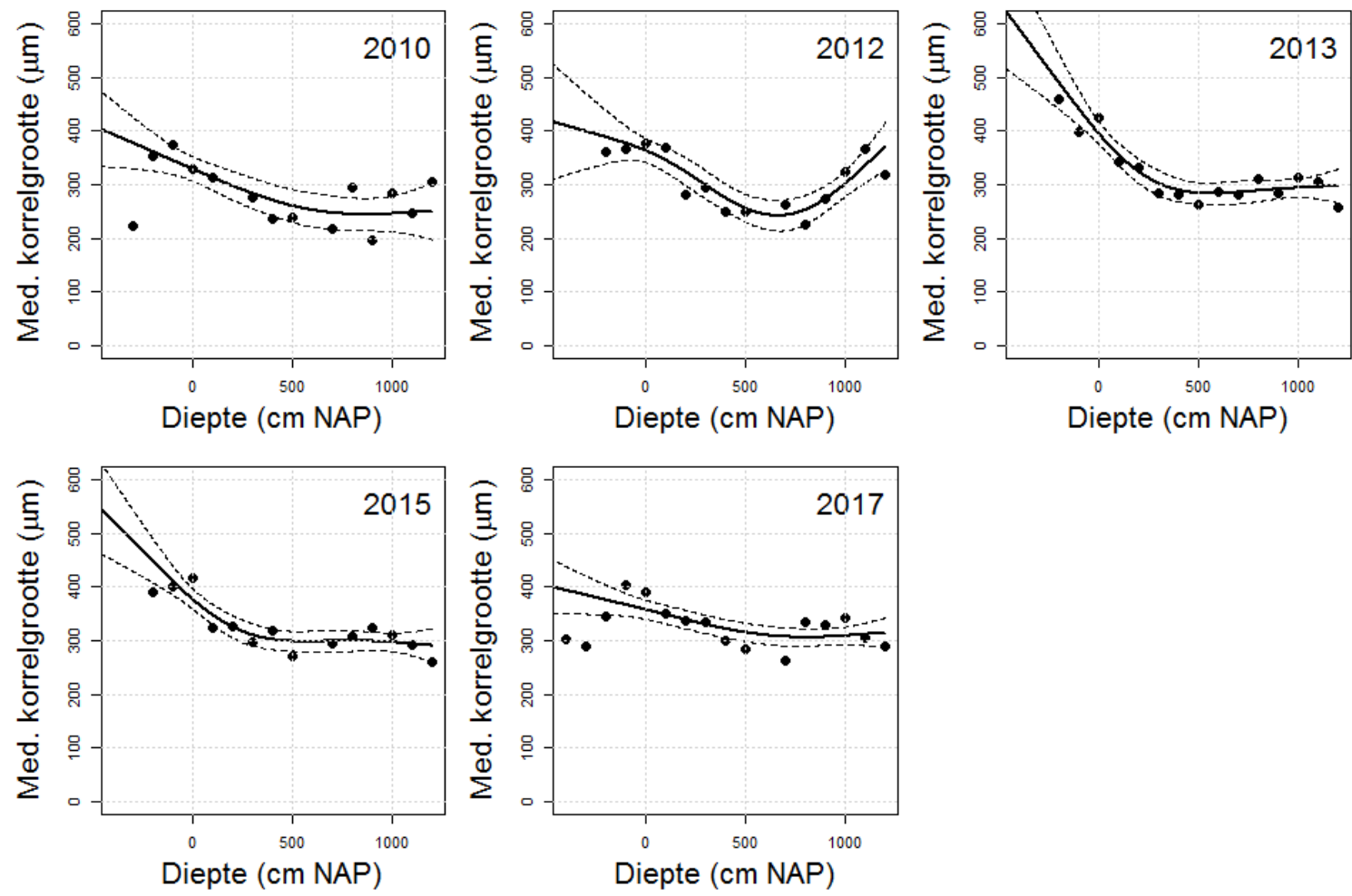

Figuur 15: Mediane korrelgrootte als functie van de diepte (cm beneden NAP) voor de verschillende jaren. De getrokken lijnen geven de resultaten van de GAM regressie en de stippellijnen geven de 95\%-betrouwbaarheid intervallen weer. De stippen geven de gemiddelde korrelgrootte per meter-interval.

In Figuur 16 zijn de ruimtelijke patronen in mediane korrelgrootte gepresenteerd voor de verschillende jaren. Hoewel het beeld vertekend is door het verschil in het aantal bemonsterde stations lijkt er na 2012 een ruimtelijk patroon te zijn ontstaan in de vooroever met relatief grove sedimenten ter hoogte van de Zandmotor (tussen transect 5 en 8), ten zuiden van de Zandmotor (tussen transecten 2 en 4) en in het Noordelijk deel (vanaf transect 10). In de tussenliggende gebieden, aan weerszijden van de Zandmotor, is het sediment juist relatief fijn. Dit ruimtelijk patroon is mogelijk het gevolg van de Zandmotor. De ter hoogte van de Zandmotor is de dynamiek toegenomen waardoor het sediment daar grover is geworden. Juist ten noorden en ten zuiden van de Zandmotor ontstaan wervelingen als gevolg van de kustlangse getijdenbeweging (Huisman et al., 2016). In deze wervelingen kan het fijnere sediment bezinken waardoor de mediane korrelgrootte afneemt.

De relatief grove sedimenten in het noordelijk deel van het onderzoeksgebied (vanaf transect 10) zijn ook al waargenomen in 2010 en hebben waarschijnlijk geen relatie met de aanleg van de Zandmotor. Hetzelfde geldt voor de relatief fijne sedimenten in de diepere delen van de meest zuidelijke transecten. In 2012 echter zijn op transect 1 ook wat grovere sedimenten aangetroffen. 


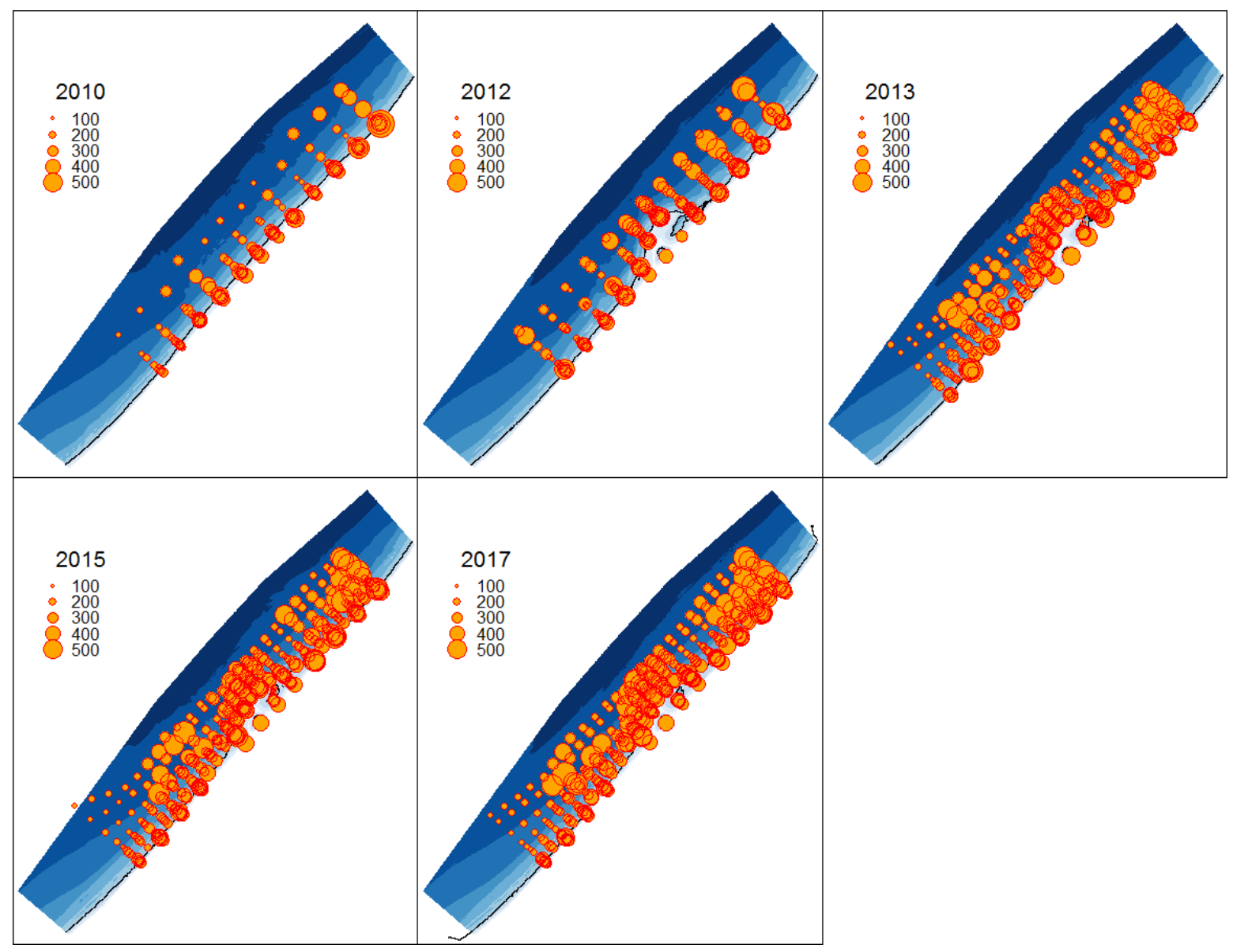

Figuur 16: Ruimtelijke verdeling mediane korrelgrootte $(\mu \mathrm{m})$ in het gebied van de Zandmotor voor de jaren 2010, 2012, 2013, 2015 en 2017.

\subsubsection{Organisch koolstof en totaal $\mathrm{N}$}

$\mathrm{Er}$ is een duidelijke relatie tussen de mediane korrelgrootte en het organisch koolstofgehalte (Figuur 17). Hoe fijner het sediment, hoe meer organisch stof. De hoogste organisch koolstoffracties worden gemeten in de fijne sedimenten met een mediane korrelgrootte minder dan $200 \mu \mathrm{m}$. Ook zijn er nog een aantal uitbijters die een relatief hoge organisch koolstoffractie hebben in relatie tot de mediane korrelgrootte. Mogelijk heeft er een stukje plantaardig of dierlijk materiaal in deze monsters gezeten. $\mathrm{Er}$ is een exponentiele functie gefit door de data met behulp van de kleinste kwadraten methode $\left(\operatorname{OrgC}=49758 \cdot\right.$ MedianeKorrelgrootte $\left.{ }^{-2.432}\right) . \mathrm{Er}$ is een lineair verband tussen de log-getransformeerde waarden van het organisch koolstof en de log-getransformeerde waarden van totaal $\mathrm{N}(\ln ($ Total $N=$ $-1.971+0.973 \cdot \ln ($ OrgC $)$, Figuur 17). Van belang in deze figuren is dat de meeste metingen beneden de detectielimiet liggen voor het organisch koolstof $(0.04 \%)$. Beneden deze waarde neemt de betrouwbaarheid van de analyse af. 

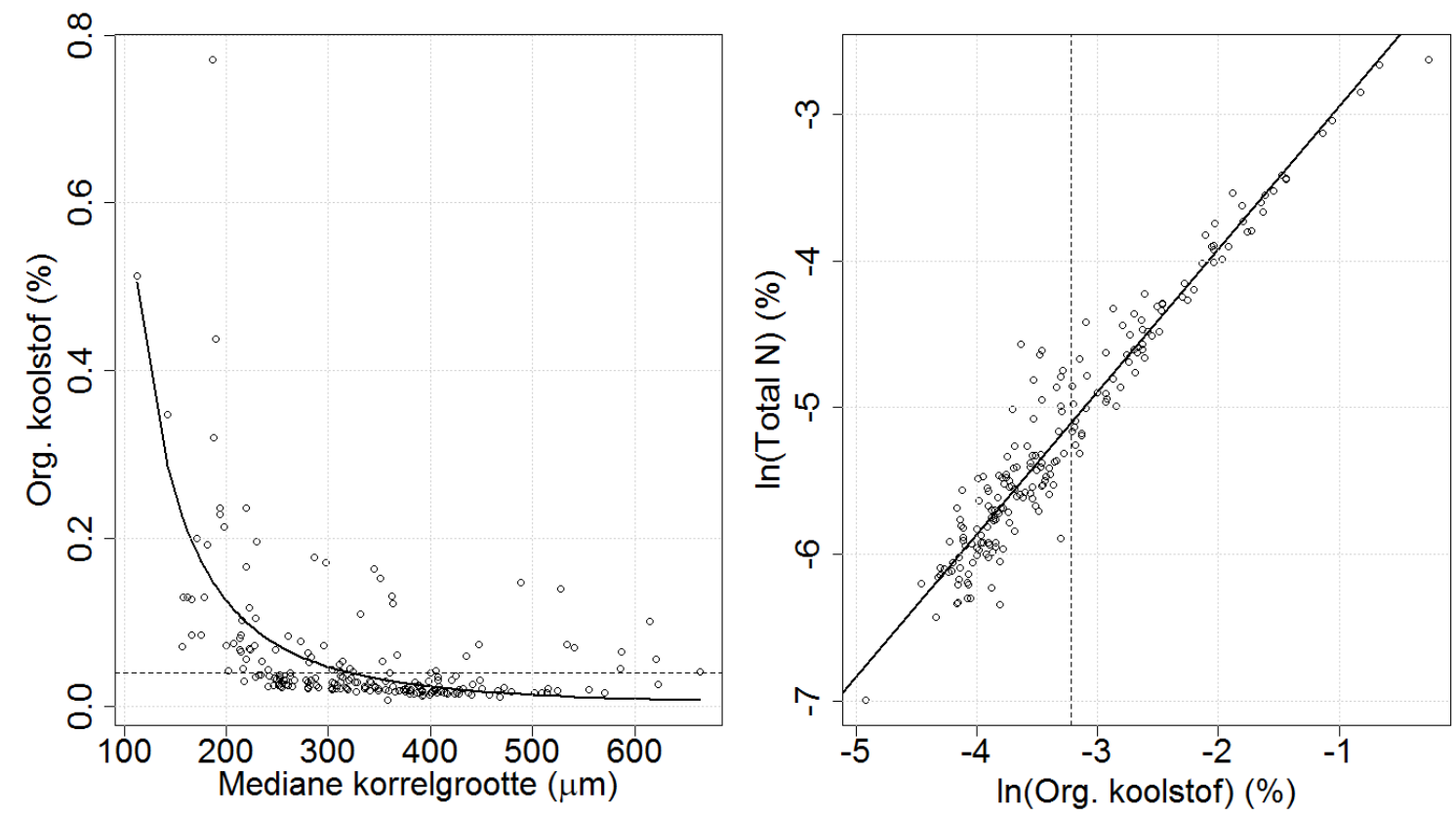

Figuur 17: Relatie tussen het organisch koolstofgehalte en de mediane korrelgrootte (links) en totaal stikstof en organisch koolstof (rechts) voor de sedimentgegevens uit 2017. De getrokken lijnen geven de resultaten van de regressies (zie tekst). De stippellijnen geven de detectielimiet voor het organisch koolstofgehalte $(0,04 \%)$.

In Figuur 18, linker figuur is te zien dat er een ruimtelijk patroon is in het organisch koolstof gehalte van de toplaag van het sediment op en rond de Zandmotor. De hoogste gehalten worden aangetroffen in de ondiepe vooroever, ten noorden en ten zuiden van de Zandmotor bij een waterdiepte van ca 5 meter maar ook in de ondiepe vooroever van Transecten 0, 1 en 2. Ook zijn er relatief hoge gehalten aan organisch koolstof aangetroffen op de stations aan het strand langs de zuidoever van de lagune. De overige stations op het strand en ook in de ondiepe brandingszone zijn relatief arm aan organisch koolstof. In het rechter deel van Figuur 18 is het absolute verschil in het percentage organisch koolstof tussen het model (getrokken lijn in Figuur 17, linker figuur) en de observaties. De locaties met de zalmkleurige stippen zijn de positieve residuelen. Op die locaties is dus een hoger gehalte aan organisch koolstof gemeten dan voorspeld met het model. De groene stippen zijn de negatieve residuelen en op die locaties is dus een lager gehalte aan organisch koolstof aangetroffen dan voorspeld met model. De positieve residuelen liggen voornamelijk in de ondiepe vooroever bij een diepte van 5 tot 10 meter en op het strand langs de zuidrand van de lagune. Opvallend is dat de stations op transect 0 op twee stations na relatief arm zijn aan organisch materiaal, gezien het sediment relatief fijn is (Figuur 12). 


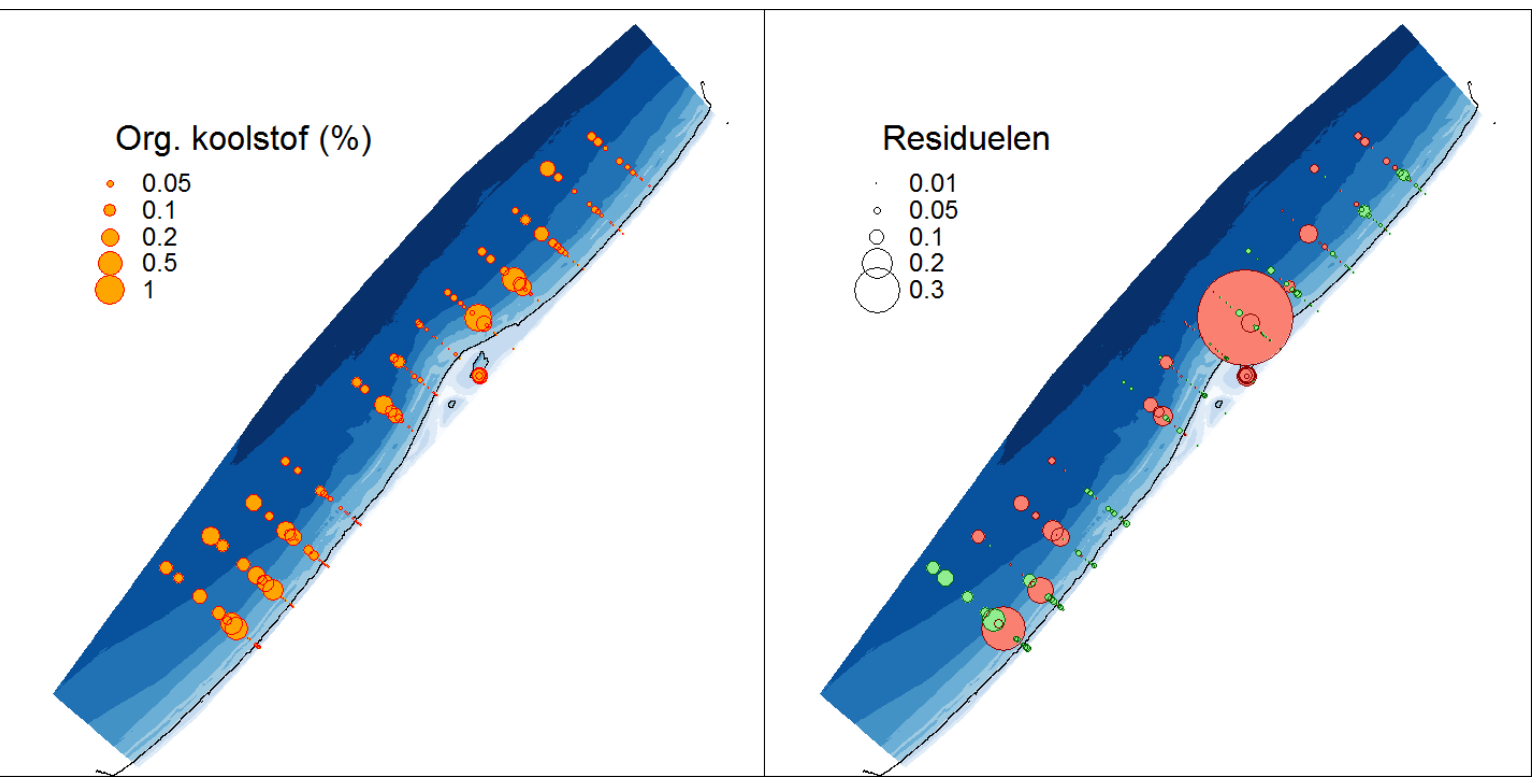

Figuur 18: Ruimtelijke verspreiding van het gehalte organisch Koolstof (\%) (links). In de rechter figuur zijn de residuelen uitgezet tussen het model (getrokken lijn in Figuur 17, linker panel) en de observaties. De locaties met de zalmkleurige stippen zijn positieve residuelen en hebben een hoger gehalte aan organisch koolstof dan voorspeld met het model. De groene stippen zijn negatieve residuelen en hebben lager gehalte aan organisch koolstof dan voorspeld met model.

\subsection{Bodemschaaf}

\subsubsection{Overzicht}

In totaal zijn er in 2017120 locaties in de vooroever bemonsterd met de bodemschaaf. De minimale treklengte was 113 meter en de maximale treklengte was 260 meter (gemiddeld 178 meter, standaard deviatie 25 meter). Op locaties 2017_112 en 2017_52 zijn geen levende bodemdieren aangetroffen. De gemiddelde biomassa (versgewicht) van bodemdieren per monster is $194 \mathrm{~g} \mathrm{~m}^{-2}$ (stdev $251 \mathrm{~g} \mathrm{~m}^{-2}$ ). De maximale biomassa is aangetroffen op locatie 2017_074 (1080 g m $\mathrm{g}^{-2}$ ). De biomassa's van de heremietkreeften (Diogenes pugilator en Pagurus bernhardus) en de otterschelpen (Lutraria lutraria) zijn hierbij niet meegenomen.
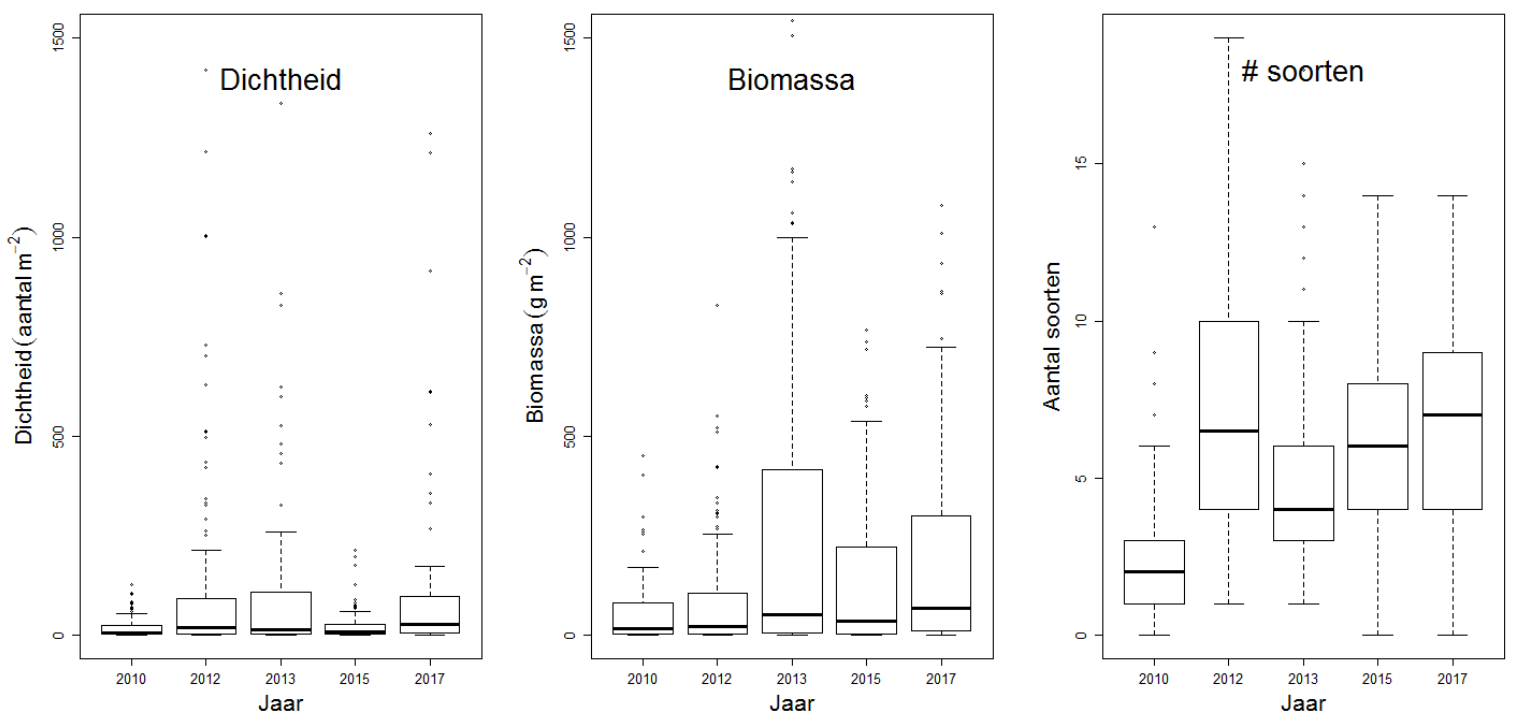

Figuur 19: Boxplots van dichtheid (aantal $\mathrm{m}^{-2}$ ), biomassa ( $\mathrm{g}$ versgewicht $\mathrm{m}^{-2}$ ) en het aantal soorten per locatie over de jaren 2010 tot en met 2017. 
De hoogste gemiddelde dichtheid $\left(136 \pm 286\right.$ ind. $\mathrm{m}^{-2}$ ) is aangetroffen in 2012 , terwijl de hoogste gemiddelde biomassa (430 $\pm 1013 \mathrm{~g}$ versgewicht $\mathrm{m}^{-2}$ ) het jaar erop (2013) is gevonden (Figuur 19). Het jaar voor de aanleg van de Zandmotor (2010) was het armste jaar zowel qua dichtheid (18 \pm 27 ind. $\left.\mathrm{m}^{-2}\right)$, biomassa $\left(57 \pm 84 \mathrm{~g}\right.$ versgewicht $\left.\mathrm{m}^{-2}\right)$ en het aantal soorten $(2.7 \pm 2.1$ soorten) per bemonsterde locatie.

In totaal zijn in 201727 taxa aangetroffen in de monsters. De meest verspreide taxa zijn het zaagje (Donax vittatus), kleine heremietkreeft (Diogenes pugilator), Ensis spp., halfgeknotte strandschelp (Spisula subtruncata), het nonnetje (Limecola balthica), gewone zwemkrab (Liocarcinus holsatus), breedpootkrab (Portumnus latipes) en witte dunschaal (Abra alba). Deze taxa zijn op meer dan 35\% van de stations aangetroffen. De helmkrab (Corystes cassivelaunus), gewone tepelhoren (Euspira catena), hooiwagenkrab (Macropodia spp.) en gewone tapijtschelp Venerupis corrugata zijn slechts op 1 station aangetroffen (Tabel 5).

Tabel 5: Aantal stations dat taxon is aangetroffen in een monster met de bodemschaaf. In 2010, 2012, 2013, 2015 en 2017 zijn er respectievelijk $114,120,113,109$ en 107 locaties bemonsterd.

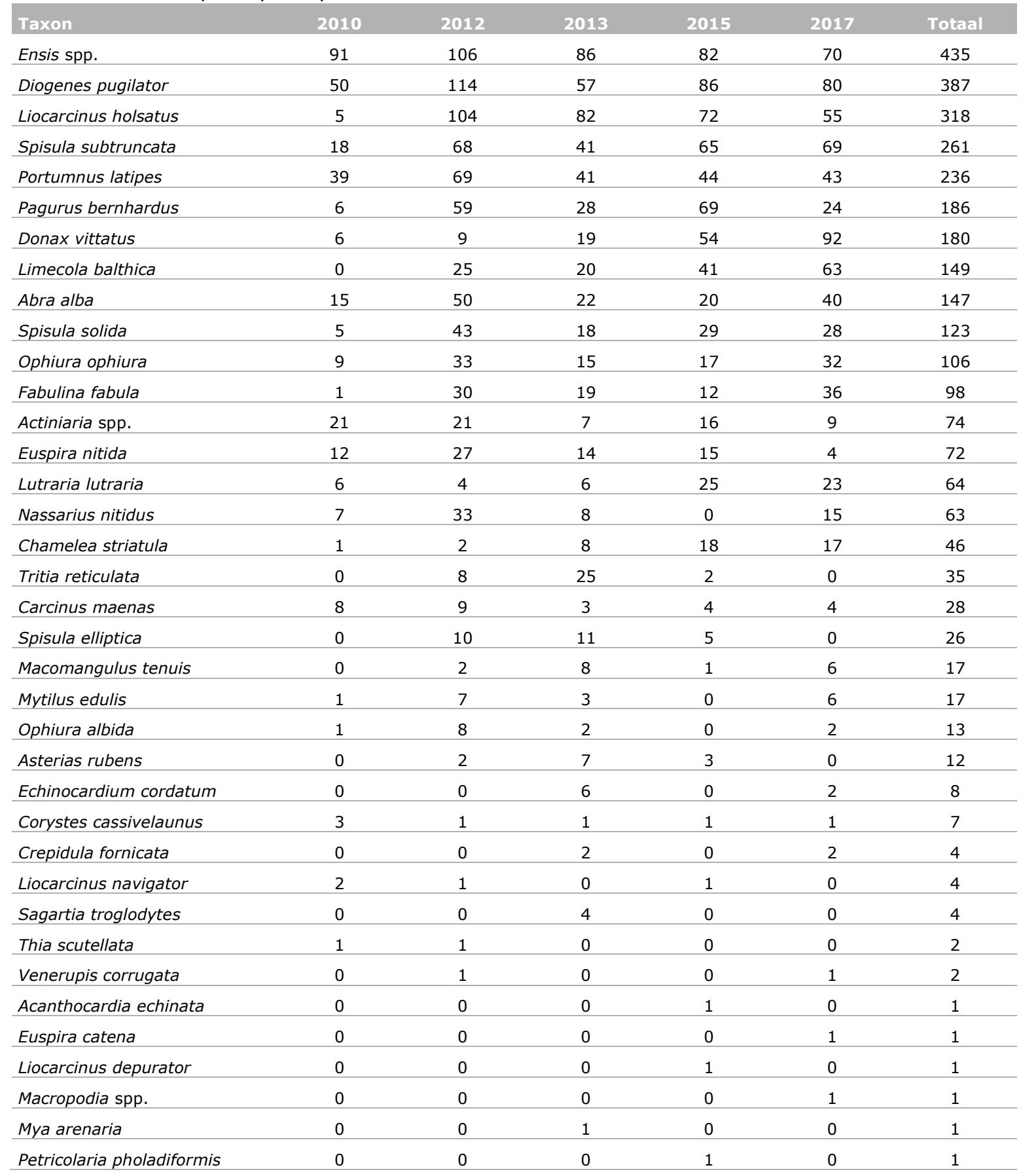


De meest dominante soorten in de bodemschaafmonsters van 2017 zijn in dichtheden het zaagje (Donax vittatus) en de halfgeknotte strandschelp (Spisula subtruncata) en met gemiddelde dichtheden van respectievelijk 54 en 46 individuen per $\mathrm{m}^{2}$ (Figuur 20). Uit de jaarlijkse schelpdierinventarisatie van Wageningen Marine Research in de Nederlandse kustzone (Troost et al., 2017) is te zien dat 2017 over het algemeen een extreem goed jaar was voor de halfgeknotte strandschelp en (in mindere mate) voor het zaagje.

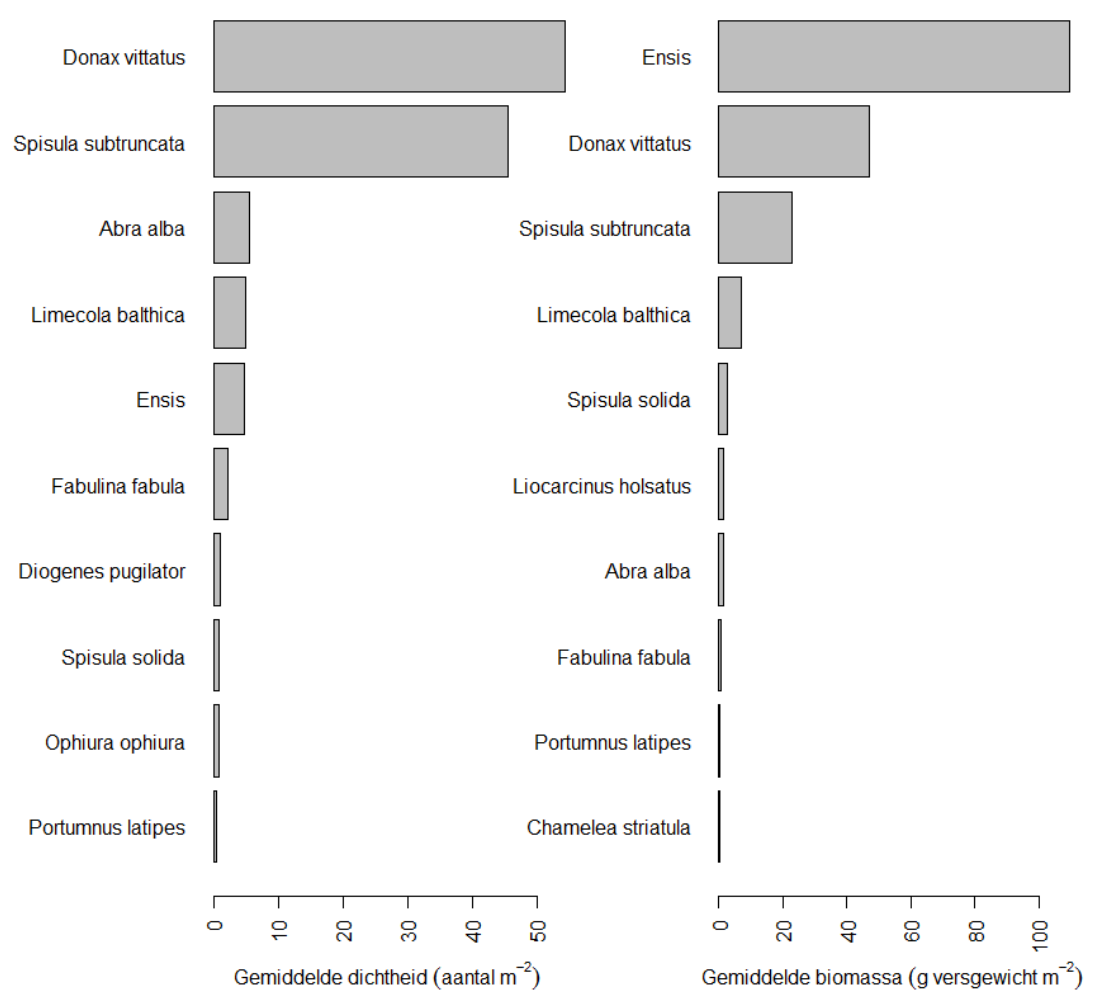

Figuur 20: Gemiddelde dichtheden en biomassa's van de 10 meest dominante soorten bij de bemonstering met de bodemschaaf in 2017. Van de soorten Diogenes pugilator, Pagurus bernhardus, Mya arenaria en Lutraria lutraria zijn geen versgewichten bepaald.

In Figuur 21 zijn de relatieve veranderingen in biomassa weergegeven voor de 20 meest dominante taxa. De linker figuur geeft het verschil tussen de gemiddelde biomassa in 2017 en de gemiddelde biomassa over de periode 2010 tot en met 2015. Te zien is dat de gemiddelde biomassa van het zaagje (Donax vitatus) in 2017 ruim 5 keer zo hoog was $\left(47.5 \mathrm{~g} \mathrm{~m}^{-2}\right)$ dan gemiddeld over de periode 2010 tot en met 2017 ( $9.3 \mathrm{~g} \mathrm{~m}^{-2}$ ). Ook van de soorten venusschelp (Chamelea striatula), nonnetje (Limecola balthica), de halfgeknotte strandschelp (Spisula subtruncata) en de rechtsgestreepte platschelp (Fabulina fabula) zijn de biomassa's in 2017 aanzienlijk hoger dan gemiddeld over de gehele periode. De biomassa's van soorten als de gewone zeester (Asterias rubens), de ovale strandschelp (Spisula elliptica) en de gevlochten fuikhoren (Tritia reticulata) daarentegen waren in 2017 juist relatief laag. Ten opzichte van 2015 zijn vooral de soorten als zaagje (Donax vitatus), de rechtsgestreepte platschelp (Fabulina fabula), venusschelp (Chamelea striatula), het nonnetje (Limecola balthica) en de halfgeknotte strandschelp (Spisula subtruncata) in biomassa toegenomen (Figuur 21, rechter panel). Soorten als de gewone zeester (Asterias rubens), de stevige strandschelp Spisula solida en de ovale strandschelp (Spisula elliptica) zijn in 2017 minder aangetroffen dan in 2015. 

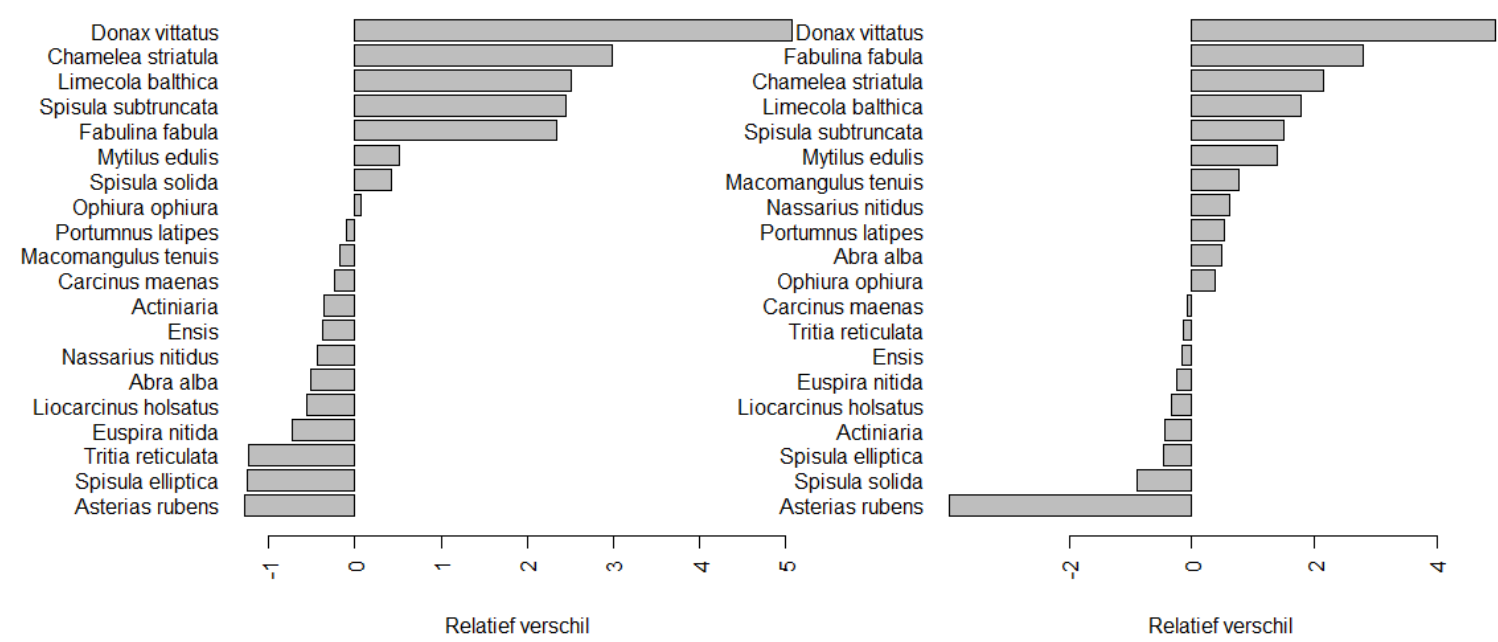

Figuur 21: Relatieve veranderingen in gemiddelde biomassa van de 20 meest dominante soorten qua biomassa. In de linker figuur is de gemiddelde biomassa in 2017 vergleken met de gemiddelde biomassa over de periode 2010 - 2015. In de rechter figuur is het verschil in biomassa weergegeven tussen 2017 en 2015 . De verschillen zijn gewogen naar het gemiddelde gewicht per soort over alle jaren.

\subsubsection{Relatie met waterdiepte}

$\mathrm{Er}$ is een duidelijke relatie tussen de dichtheid en biomassa aan bodemdieren in de bodemschaaf met de waterdiepte (Figuur 22). In het ondiepe deel van de vooroever ( $<6$ meter onder NAP) is de dichtheid en biomassa van de bodemdieren in de bodemschaaf zeer laag. Vanaf een diepte van 6 á 7 meter nemen zowel de gemiddelde biomassa als de dichtheid toe met de diepte. Ook het aantal soorten dat is aangetroffen neemt toe met de waterdiepte, van gemiddeld minder dan 5 soorten bij een diepte van minder dan 5 meter tot gemiddeld bijna 10 soorten per locatie bij een diepte van 11.5 meter beneden NAP.
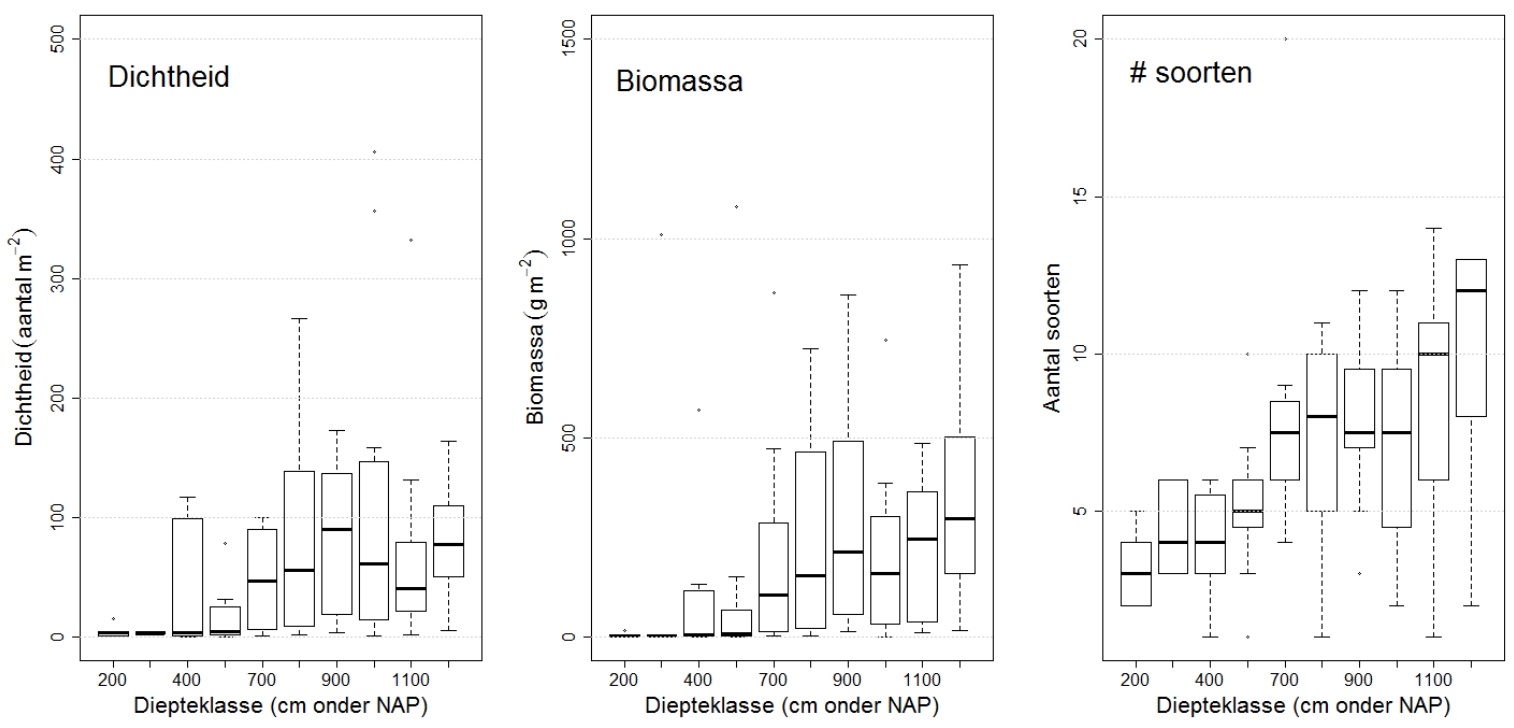

Figuur 22: Boxplots van dichtheid (aantal $\mathrm{m}^{-2}$ ), biomassa ( $\mathrm{g}$ versgewicht $\mathrm{m}^{-2}$ ) en aantal soorten in 2017 als functie van de waterdiepte. 
Hetzelfde beeld is te zien in de resultaten van de GAM analyse voor biomassa (Figuur 23). Het GAM model is significant $(p<0.05)$ en geeft aan dat er een significant effect is van waterdiepte op de biomassa. De punten in de figuur geven de gemiddelde biomassa aan bodemdieren per diepteklasse weer.

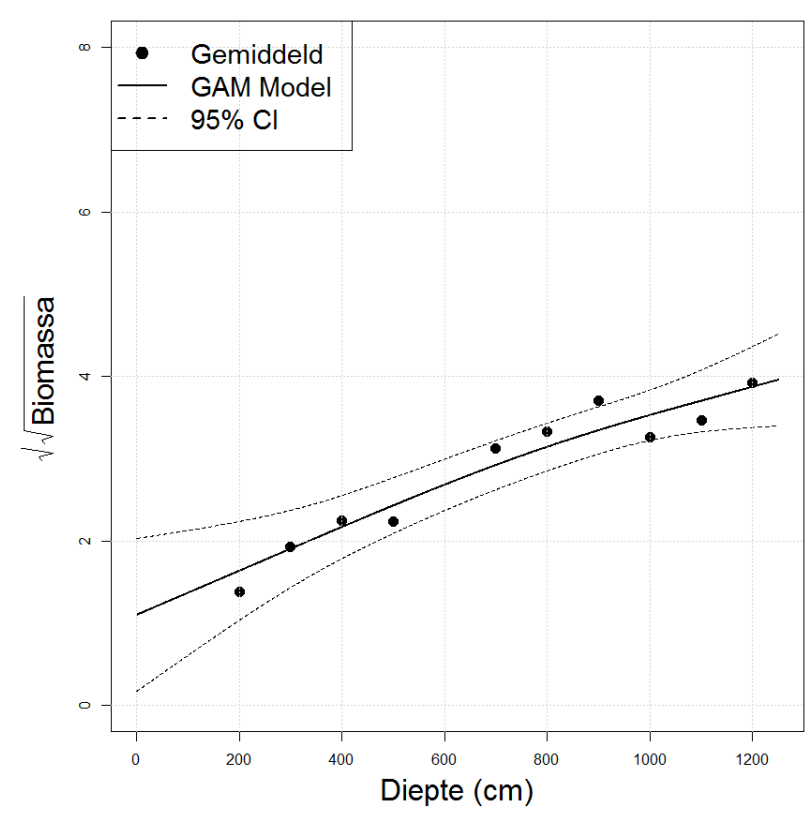

Figuur 23: Vierdemachtswortel-getransformeerde biomassa ( $\mathrm{g}$ versgewicht $\mathrm{m}^{-2}$ ) als functie van de diepte (centimeter beneden NAP) van het benthos verzameld met de bodemschaaf. De getrokken lijn geeft het resultaat van het GAM model als functie van de diepte en de stippellijnen geven de 95\%-betrouwbaarheid intervallen weer.

Uit Figuur 24 blijkt dat er niet voor alle transecten een toename van de biomassa is met de waterdiepte. Op de transecten 7, 9 en 12 was het GAM model niet significant en op transect 8 blijkt er een juist een afname te zijn in biomassa met de waterdiepte. Deze afname met de waterdiepte op transect 8 wordt voornamelijk veroorzaakt door hoge biomassa's aan zaagjes (Donax vittatus) in de ondiepe stations van het transect (2017_072, 2017_73, 2017_74 en 2017_75) (Figuur 60). 

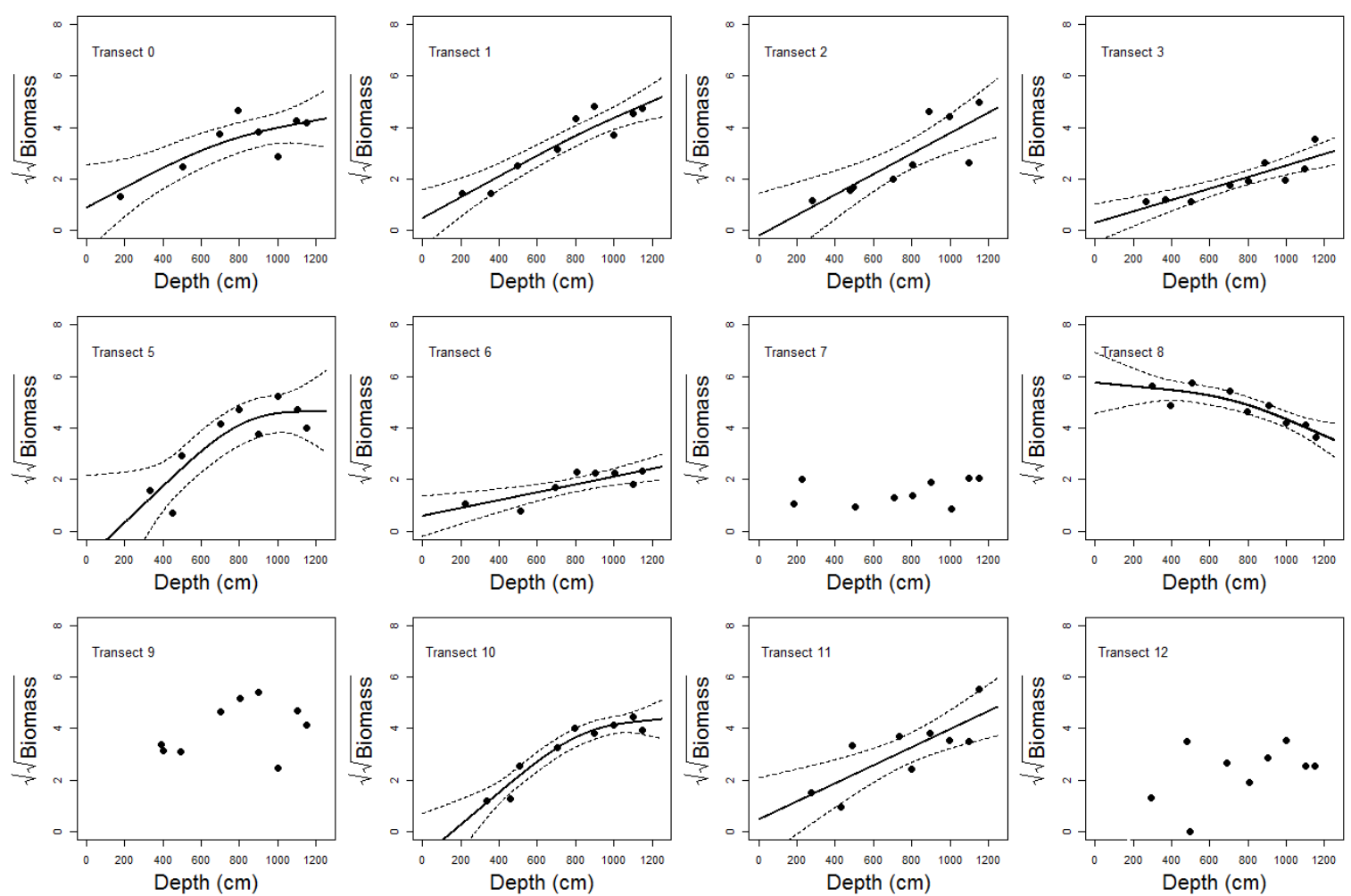

Figuur 24: GAM regressiemodellen voor de vierdemachtswortel-getransformeerde biomassa als functie van de waterdiepte ( $\mathrm{cm}$ beneden NAP) voor de 12 transecten. Alleen de significante GAM modellen zijn geplot.

Op de transecten 2, 11 en 12 is er geen duidelijk effect van de jaren op de relatie van de biomassa en waterdiepte (Model 1, Figuur 25). Voor een aantal transecten (3\&4, 5, 6 en 10) zijn de patronen hetzelfde maar zijn er wel verschillen over de jaren (Model 2). Op de transecten 5 en 10 waren de biomassa's in 2010 het laagste en in 2013 het hoogste. Op de transecten 3\&4 en 6 was juist de biomassa in 2015 het laagst. Op de transecten 0\&1, 7, 9 en 9 varieert het patroon met de diepte over de jaren (Model 3). 

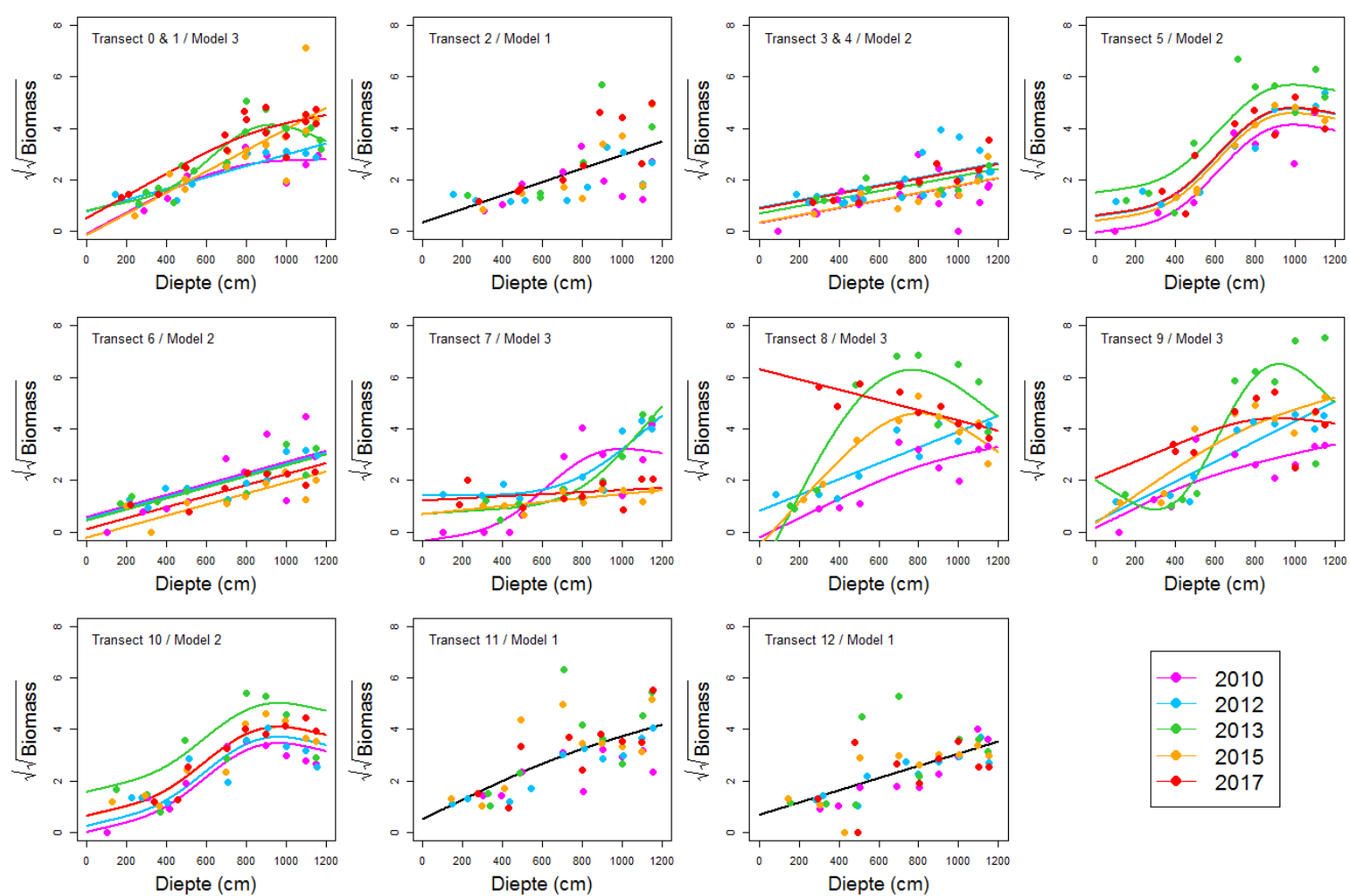

Figuur 25: Biomassa bodemdieren $\left(\mathrm{g} \mathrm{m}^{-2}\right)$ als functie van de diepte ( $\mathrm{cm}$ beneden NAP) met jaar als factor voor de verschillende transecten. Bij Model 1 (getrokken zwarte lijnen) is er geen significant verschil tussen de jaren. Bij model 2 is er wel een significant verschil tussen de jaren, maar is er geen verschil in het patroon met de diepte. Bij model 3 is er ook een significant verschil in het patroon met de diepte tussen de verschillende jaren.

\subsubsection{Relatie met sedimentsamenstelling}

Zoals verwacht is er een relatie tussen de bodemdiergemeenschap en de sedimentsamenstelling (Figuur 26). De hoogste dichtheden en biomassa's worden gevonden bij een mediane korrelgrootte van minder dan $300 \mu \mathrm{m}$, hoewel er ook op enkele stations met een mediane korrelgrootte van $400 \mu \mathrm{m}$ en meer biomassa's van meer dan $200 \mathrm{~g}$ versgewicht $\mathrm{m}^{-2}$ zijn aangetroffen. Ook worden er per station meer soorten aangetroffen op de locaties met de fijnere sedimenten.
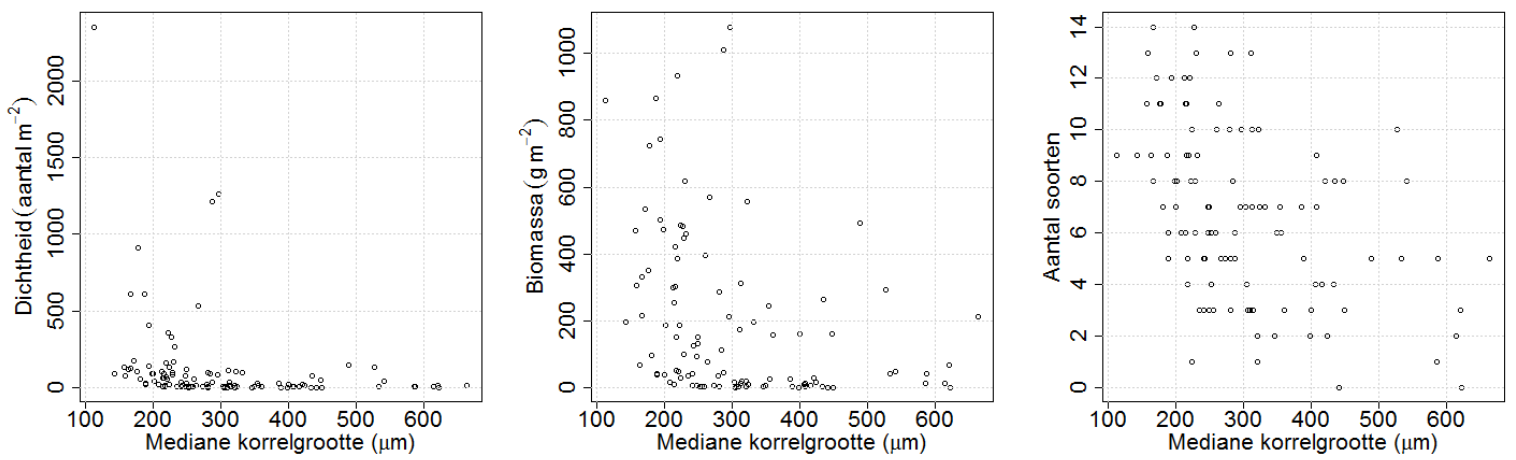

Figuur 26: Relatie tussen dichtheid, biomassa en aantal soorten per locatie op de verticale as en mediane korrelgrootte op de horizontale as voor de bodemschaafbemonstering in 2017. 


\subsubsection{Ruimtelijke verspreiding}

In Figuur 27, linker deel, is de ruimtelijke verspreiding van de totale biomassa weergegeven. In Bijlage 5 is de verspreiding weergegeven van een aantal dominanten soorten. Omdat Ensis sp. het meest dominante genus is in biomassa vertoont de verspreiding van dit genus (Figuur 61) veel overeenkomsten met de verspreiding van de totale biomassa. In de ondiepe brandingszone komen Ensis spp. niet of in zeer lage biomassa's voor. Ook op transect 3, ten zuiden van de Zandmotor en op de transecten 6 en 7, voor de Zandmotor komen Ensis spp. zeer beperkt voor. Stevige strandschelpen (Spisula solida), zijn voornamelijk aangetroffen in de diepere, relatief grove sedimenten in het noorden van het onderzoeksgebied (Figuur 65), terwijl de halfgeknotte strandschelpen (Spisula subtruncata) meer zijn aangetroffen in de diepere delen van de Zandmotor in het zuidelijk gebied en ook op de transecten 5 en 9 (Figuur 66). Het zaagje (Donax vitatus) lijkt een voorkeur te hebben voor de relatief ondiepe delen (Figuur 60). Dit geldt ook voor het nonnetje (Limecola balthica, Figuur 63). De witte dunschaal (Abra alba, Figuur 59) komt voornamelijk voor in de diepere delen. De hoogste biomassa's van deze soort zijn gevonden op de transecten 0, 1 en 2. De breedpootkrab (Portumnus latipes) is een karakteristieke soort voor de ondiepe brandingszone (Figuur 68). In de rechterdeel van Figuur 27 is de totale biomassa van bodemdieren zonder Ensis spp. weergegeven. Opvallend in de figuur is dat twee transecten rond de Zandmotor (transecten 6 en 7) een relatief lage biomassa hebben. Op deze transecten is vrijwel geen Ensis spp. aangetroffen (Figuur 61) maar ook de biomassa van de andere soorten is laag. Transecten 8 en 9 hebben een relatief hoge biomassa, ook met weglating van Ensis spp. Deze hoge biomassa's worden vooral veroorzaakt door de aanwezigheid van het zaagje (Donax vittatus) en de halfgeknotte strandschelp (Spisula subtruncata).

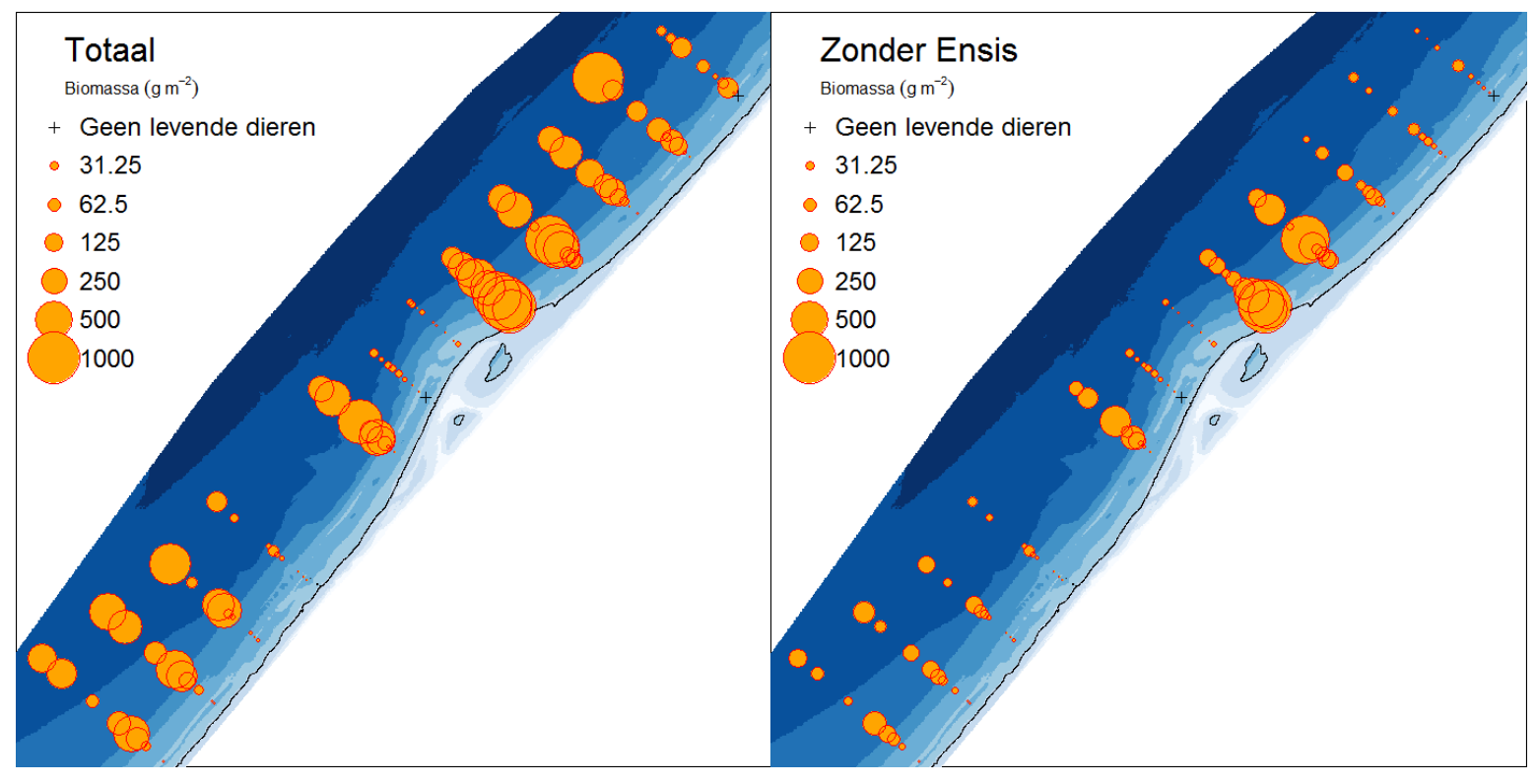

Figuur 27: Verspreidingskaart totale bodemdierbiomassa ( $\mathrm{g}$ versgewicht $\mathrm{m}^{-2}$ ) bemonsterd met de bodemschaaf in 2017. De linker figuur geeft de totale biomassa en de rechterfiguur geeft de biomassa met weglating van Ensis spp.

In Figuur 28 zijn respectievelijk de dichtheden, biomassa's en het aantal soorten per locatie uitgezet tegen het transect. Ook in deze figuur is te zien dat de transecten 8 en 9 een hoge dichtheid en biomassa hebben, terwijl de transecten 6 en 7, maar ook transecten 3 en 12 een relatief lage biomassa en dichtheid hebben. Er lijkt een duidelijke gradiënt te zijn in afname van zowel de dichtheid als biomassa gaande van transect 8 naar transect 12 . Het aantal aangetroffen soorten per station is relatief hoog in de meest zuidelijke transecten ( 0 tot en met 5 ) en net ten noorden van de Zandmotor (transecten 8, 9 en 10). 


$$
\text { "If }
$$


clusters die aangegeven zijn met de rode lijnen zijn niet significant $(p>0.05)$. Dit wil zeggen dat de verschillen in bodemdiergemeenschap die zijn aangetroffen tussen deze clusters waarschijnlijk berust op toeval (variatie binnen de groep). De labels die zijn gebruikt geven het cluster aan.

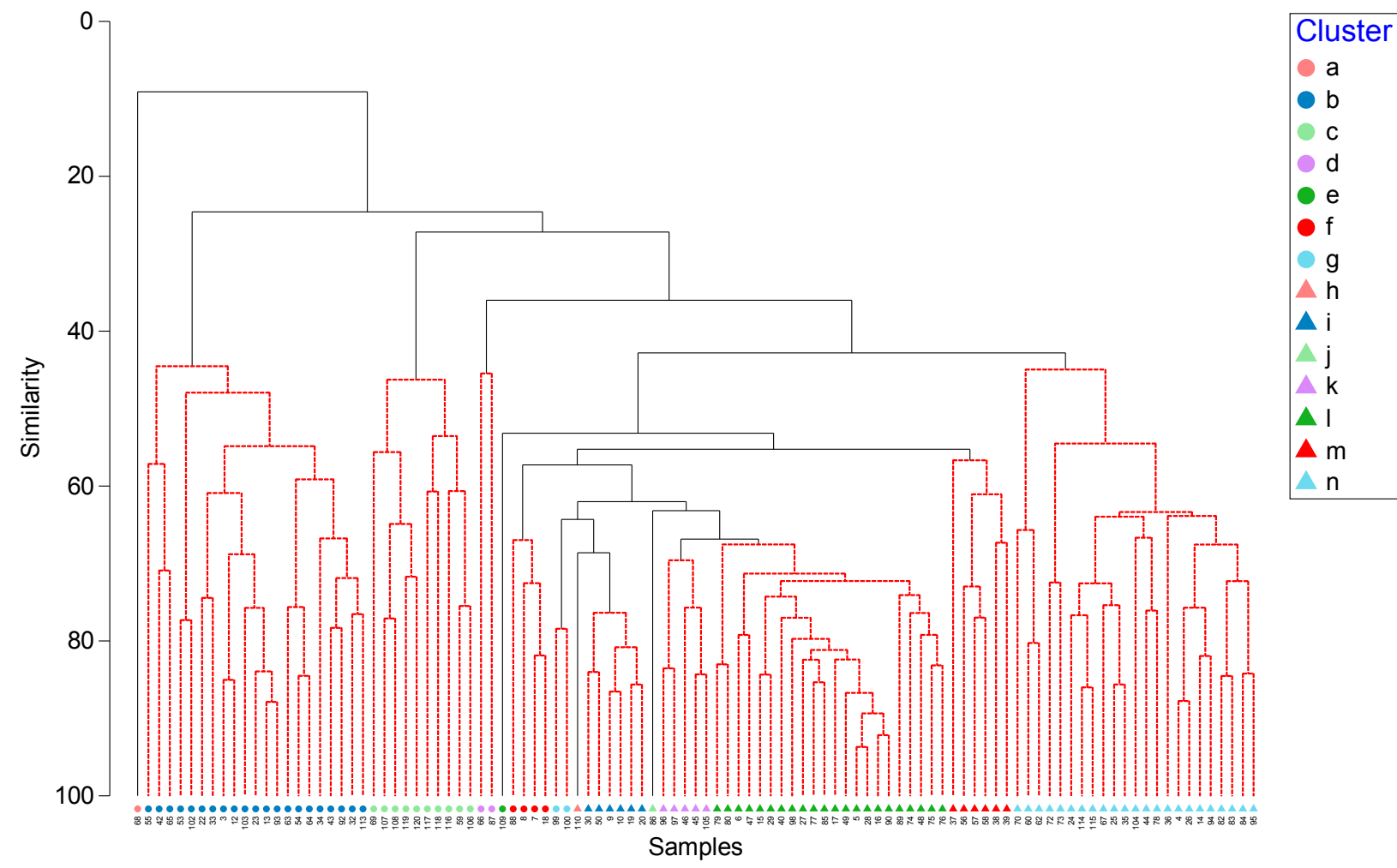

Figuur 30: Clusterdiagram van bodemdieren in de bodemschaaf in 2017. De zwarte lijnen geven de significante clusters (Simprof test, $\mathrm{p}<0.05$ )

In Figuur 31 is de ruimtelijke verspreiding weergegeven van de 14 significante clusters over het gebied rond de Zandmotor. Clusters $\mathrm{a}, \mathrm{e}, \mathrm{h}$ en $\mathrm{j}$ zijn clusters bestaande uit een enkel station (respectievelijk 2017_68, 2017_109,2017_110 en 2017_86). Cluster b bestaat uit 21 ondiepe stations. Op de kop van de Zandmotor (transecten 6 en 7) zijn er ook nog wat diepere stations die binnen dit cluster vallen. Cluster $\mathrm{c}$ is een groep van 10 stations die zich voornamelijk bevinden op de diepere delen van de transecten 11 en 12. Het sediment op deze stations is relatief grof (Figuur 12) en de bodemdiergemeenschap wordt gekenmerkt door de aanwezigheid van de stevige strandschelp (Spisula solida). De 23 stations van cluster $\mathrm{n}$ bevinden zich voornamelijk in de ondiepe vooroever, iets dieper van de stations uit cluster $b$, maar ook op de diepere delen van de transecten op de Zandmotor (transecten 6, 7 en 8). De clusters I (22 stations) en m (6 stations) liggen weer op grotere diepte dan de stations van cluster $\mathrm{n}$. Cluster I ontbreekt opvallend op de transecten 6 en 7 alsook op de transecten 11 en 12. De 6 stations van cluster i bevinden zich uitsluitend op de grotere diepten van de transecten ten zuiden van de Zandmotor. Drie van de 4 stations van cluster $\mathrm{f}$ liggen ruimtelijk dicht bij elkaar op de transecten 0 en 1 . Het vierde station ligt op transect 9.

Dezelfde clusteranalyse is tevens uitgevoerd voor de jaren 2010, 2012, 2013 en 2015 afzonderlijk. De resultaten hiervan zijn gepresenteerd in Bijlage 6 (Figuur 69 tot en met Figuur 72). De (ruimtelijke) patronen die zijn gevonden in 2017 komen overeen met de patronen die zijn gevonden in 2012, 2013 en 2017. Het patroon in 2010 echter was wel afwijkend. Ten eerste zijn er in 2010 slechts 5 clusters aangetroffen, wat wijst op een mindere ruimtelijke variëteit in bodemdiergemeenschappen. Ook in 2010 was er, naast de diepte gradiënt in de clusters ook al een kustlangse gradiënt. Zo namen de clusters $b$ en $d$ af, en het cluster e toe gaande van transect 1 naar transect 12 . 


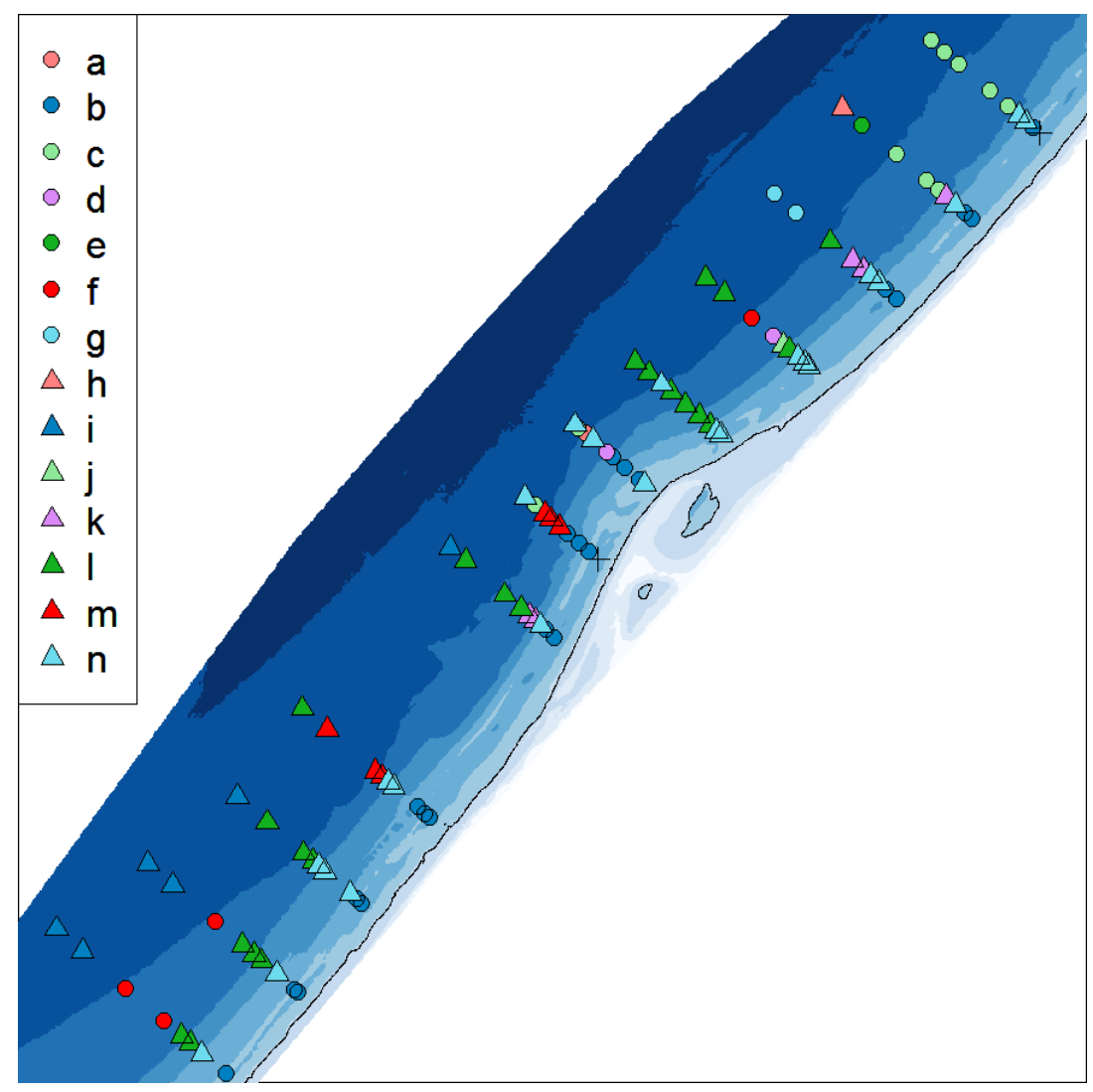

Figuur 31: Verspreidingskaart significante clusters bodemdiergemeenschappen bodemschaaf 2017

In Figuur 32 is de nMDS plot van de data van de bodemschaaf uit 2017 weergegeven. De markers geven de clusters uit de clusteranalyse (Figuur 30 ) weer. In de figuur is duidelijk te zien dat de clusters b, $c$ en g zich ook op de nMDS duidelijk onderscheiden van de overige clusters. In Figuur 33 zijn de markers van de nMDS vervangen door taartdiagrammen voor de breedpootkrab (Portumnus latipes), de stevige strandschelp (Spisula solida), het zaagje (Donax vittatus) en Ensis spp. als karakteristieke soorten voor de verschillende clusters. In Figuur 34 ten slotte is de verspreiding van de dichtheden van deze soorten over het gebied rond de Zandmotor weergegeven. 


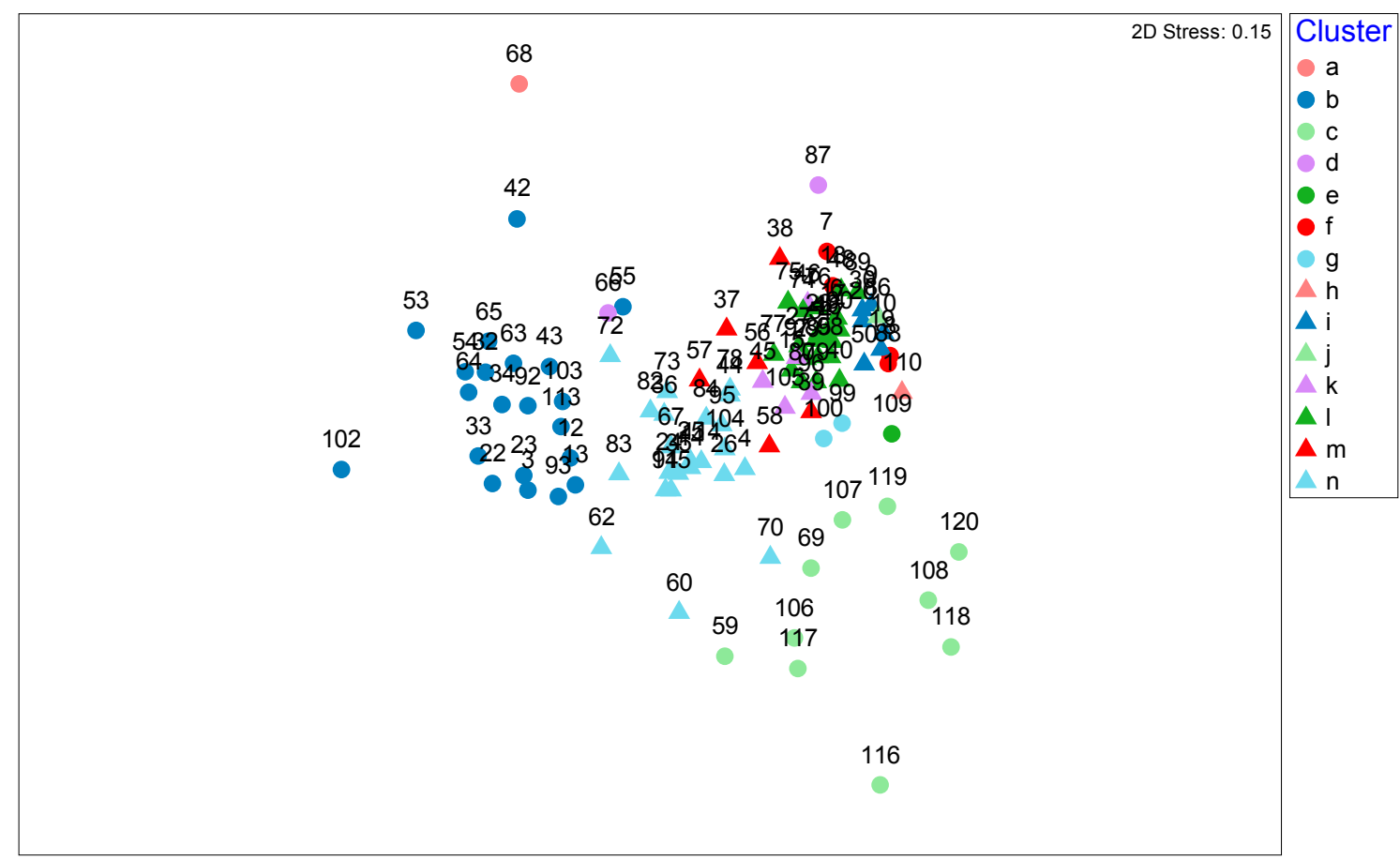

Figuur 32: nMDS plot data bodemschaaf voor 2017. De labels geven de nummers van de bemonsteringslocaties weer. De kleur van de markers representeren de clusters uit de clusteranalyse.

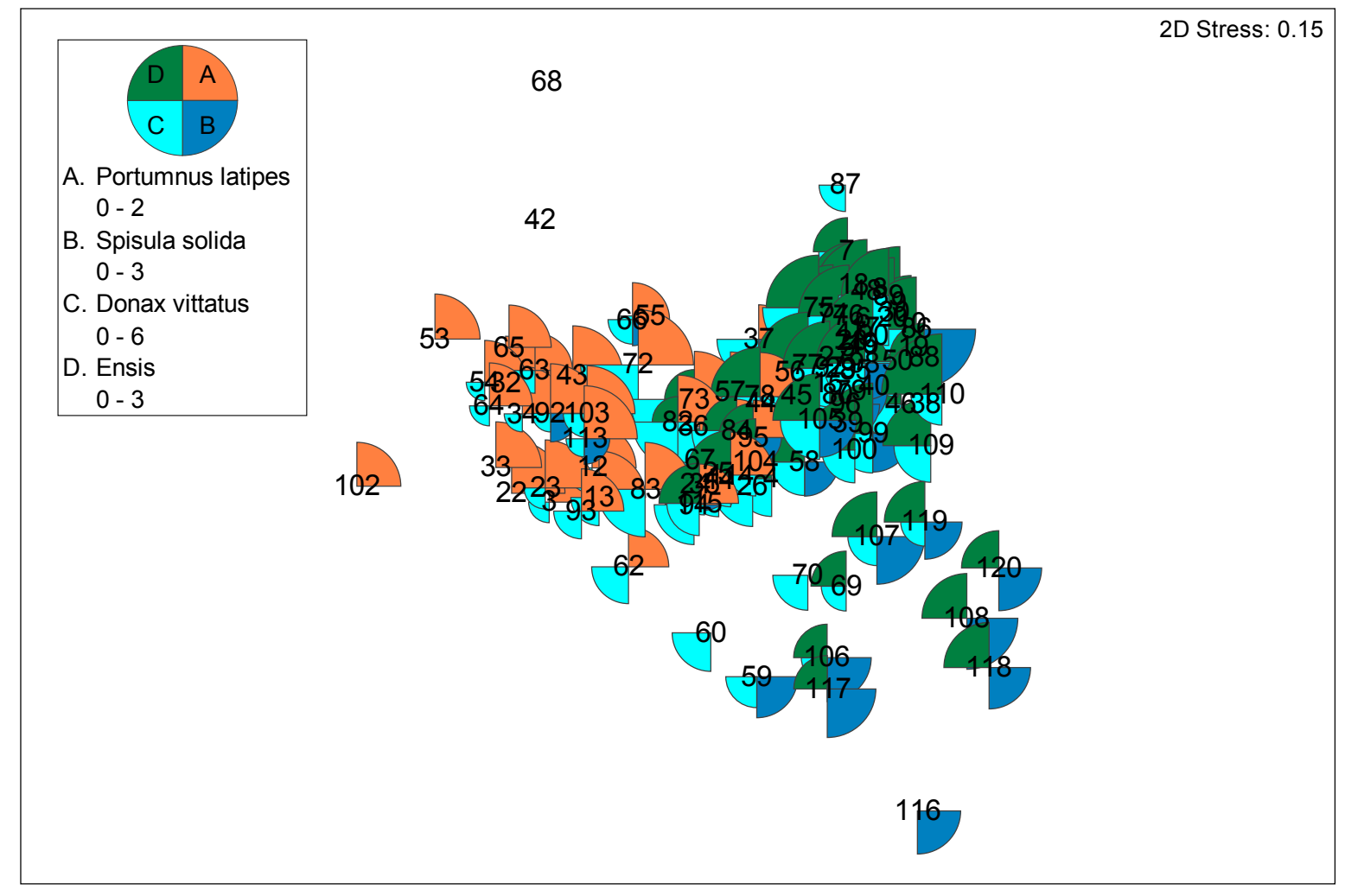

Figuur 33: nMDS plot data bodemschaaf 2017, als in Figuur 32. De markers geven nu het relatieve aandeel van de belangrijkste soorten weer. De verspreiding van deze soorten is weergegeven in Figuur 34. 


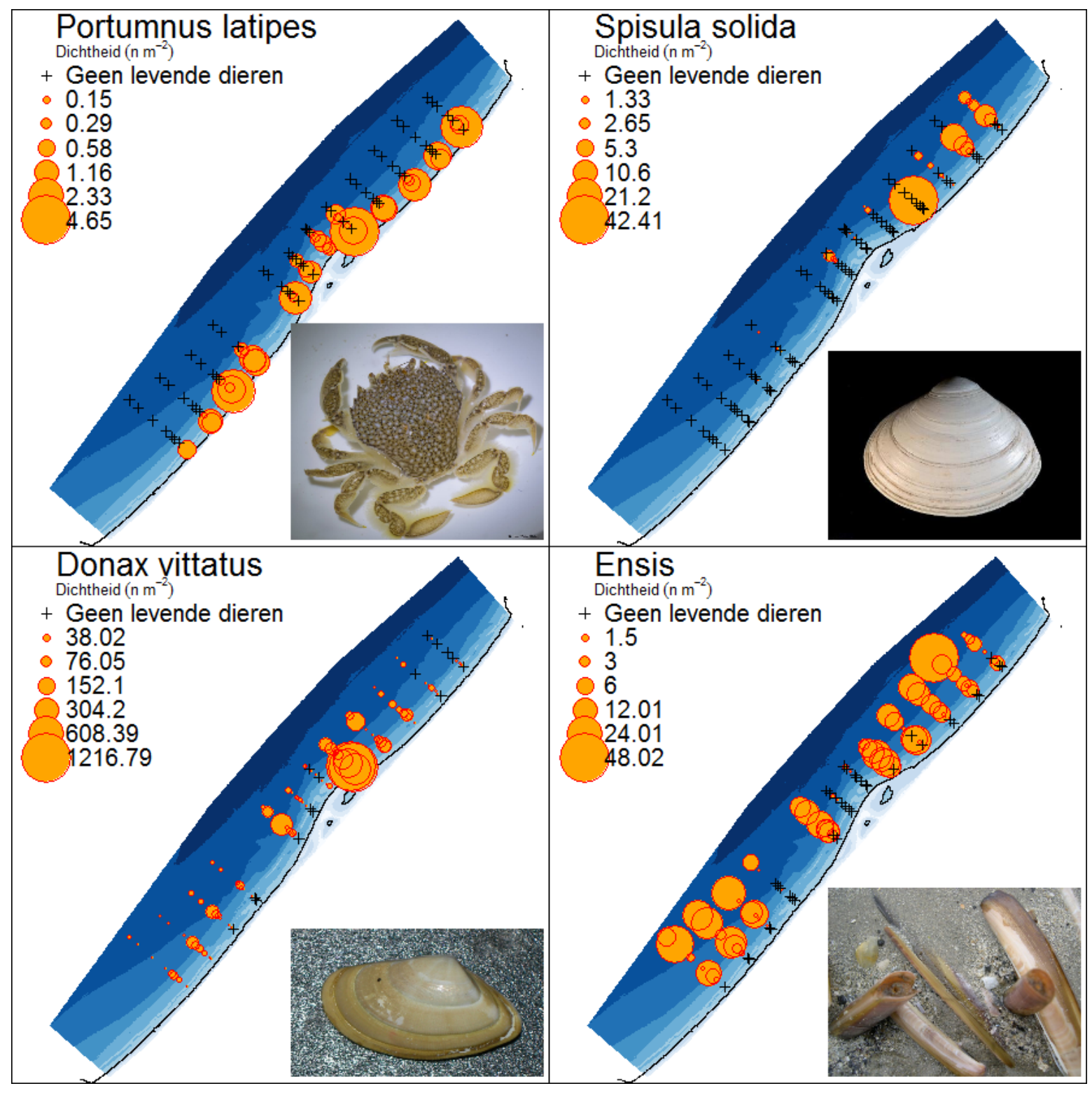

Figuur 34: Verspreiding van dichtheden van de soorten Portumnus latipes, Spisula solida, Donax vittatus en Ensis spp. in 2017.

Om de ontwikkeling in de tijd te visualiseren zijn er niet-metrische MDS plots gemaakt op geaggregeerde data over alle jaren. De dichtheden zijn hiervoor gemiddeld per jaar en gebied (Zuid, Zandmotor, Noord, Figuur 35) en per jaar en dieptestratum (Figuur 36). Voor alle gebieden is er een vergelijkbaar patroon over de tijd (2010 naar 2017). Het jaar 2010 wijkt hierbij het sterkst af van de overige jaren. Het jaar 2012 lijkt relatief uniform wat aangeeft dat er in dat jaar relatief weinig verschil is tussen de gebieden Zuid, Zandmotor en Noord. In 2015 vertonen de gebieden Noord en Zandmotor sterke overeenkomsten terwijl het gebied Zuid hiervan afweek. Uit de figuur is af te leiden dat er een ontwikkeling in de bodemdiergemeenschap heeft plaatsgevonden in alle drie de deelgebieden en dat het de jaarlijkse verschillen groter zijn dan de verschillen tussen de drie deelgebieden. De bodemdiergemeenschap gaat steeds meer afwijken van de bodemdiergemeenschap die in 2010 is aangetroffen. Dit geldt voor alle drie de deelgebieden. Uit de figuur is duidelijk te zien dat de bodemdiergemeenschap in het onderzoeksgebied zich aan het ontwikkelen is na de aanleg van de Zandmotor. De gemeenschap heeft zich niet ontwikkeld naar de situatie van voor de aanleg (2010). 


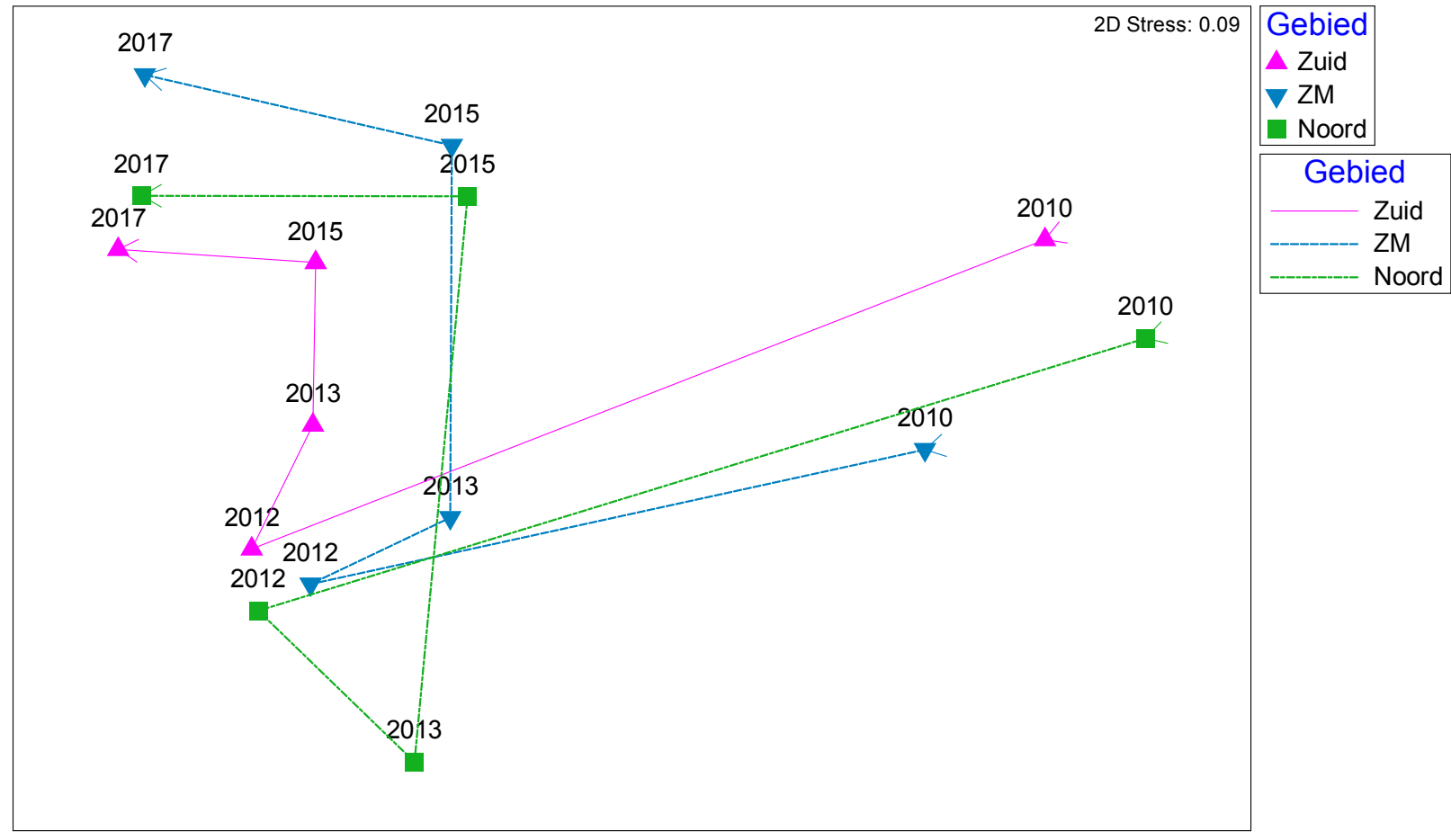

Figuur 35: nMDS plot van de ontwikkeling van de bodemdiergemeenschap over de tijd voor de drie verschillende deelgebieden (Zuid, Zandmotor en Noord). De afstand tussen de punten is een maat voor de dissimilariteit in de bodemdiersamenstelling

In Figuur 36 is eenzelfde figuur gemaakt waarbij de data zijn geaggregeerd voor de factoren diepte en jaar. Met de kleuren zijn de jaren aangegeven en de getallen geven het dieptestratum aan (zie ook Tabel 1). Uit de figuur is duidelijk af te leiden dat er een diepte gradiënt zit in de bodemdiergemeenschap, waarbij de ondiepte stations een relatieve lage waarde op de horizontale as van het nMDS plot. Het jaareffect zit voornamelijk op de verticale as, waarbij er een duidelijke gradiënt is van 2010 naar 2017. Ook uit deze figuur blijkt dat de bodemdiergemeenschap zich nog steeds aan het ontwikkelen is en niet terug is in de situatie van 2010. 


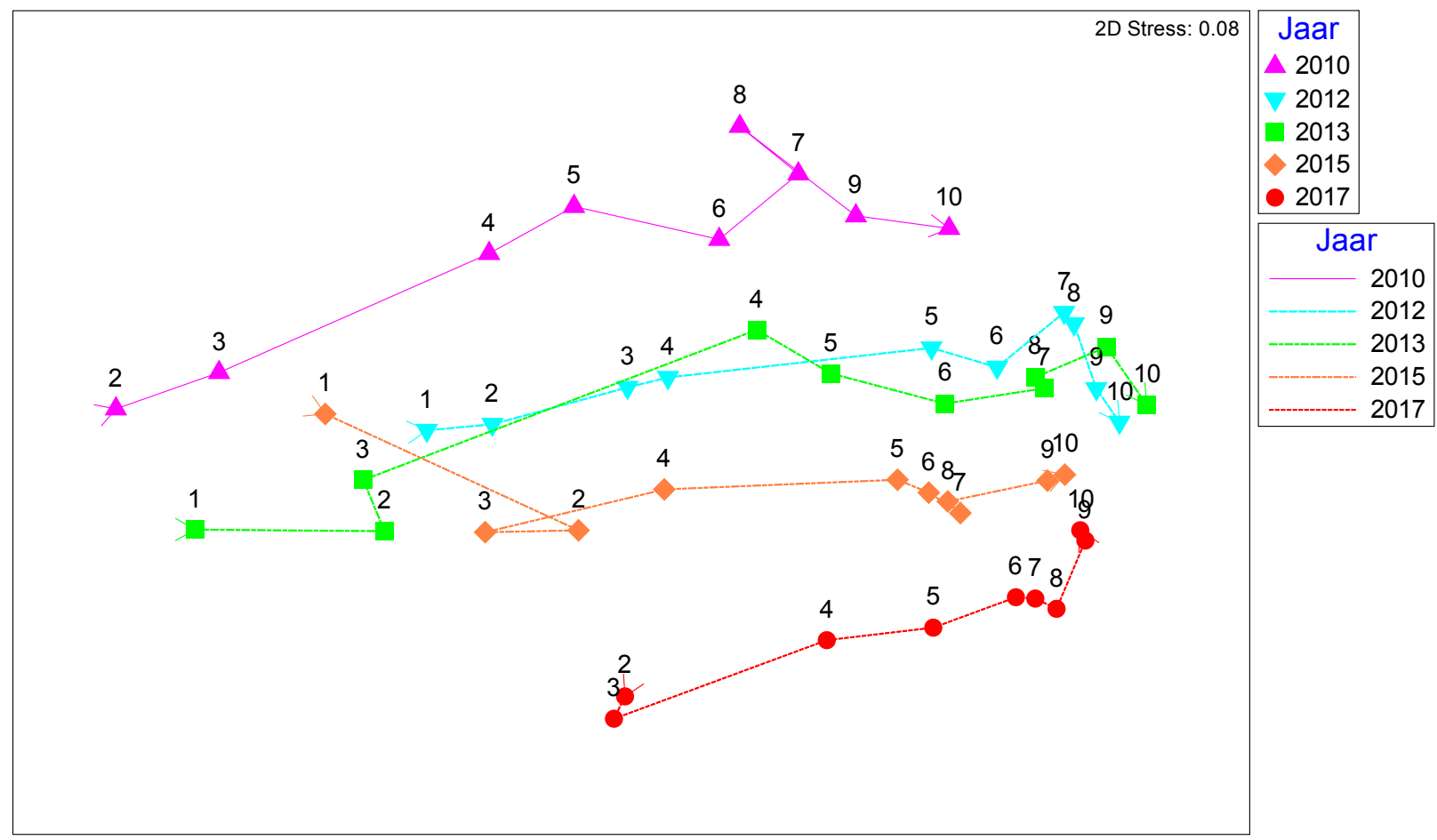

Figuur 36: nMDS plot van de ontwikkeling van de bodemdiergemeenschap als functie van de diepte voor de verschillende jaren. De afstand tussen de punten is een maat voor de dissimilariteit in de bodemdiersamenstelling

\subsection{Van Veen bemonstering}

\subsubsection{Overzicht}

In totaal zijn er in 2017120 locaties bemonsterd met de Van Veen happer. De gemiddelde totale dichtheid aan bodemdieren in 2017 was 1031 individuen $\mathrm{m}^{-2}$ (stdev 1377 individuen $\mathrm{m}^{-2}$ ) en is vergelijkbaar met 2013 en 2015 (respectievelijk 1357 en 874 ind. $\mathrm{m}^{-2}$ ) maar lager dan in 2012 (2166 ind. $\mathrm{m}^{-2}$ ) (Figuur 37). De hoogste dichtheid in 2017 was 7570 individuen $\mathrm{m}^{-2}$ (voornamelijk Spisula subtruncata) op locatie 2017_087. De gemiddelde biomassa aan bodemdieren was $15.2 \mathrm{~g} \mathrm{AFDW} \mathrm{\textrm {m } ^ { - 2 }}$ (stdev $77 \mathrm{~g} \mathrm{AFDW} \mathrm{m}^{-2}$ ) en het gemiddeld aantal aangetroffen taxa per monster was 14.4. Het maximaal aantal taxa (51) is aangetroffen op locatie 2017_109. Wat betreft gemiddelde dichtheid, biomassa en aantal taxa was 2010 het armste jaar (gemiddeld 9.6 taxa per station). 

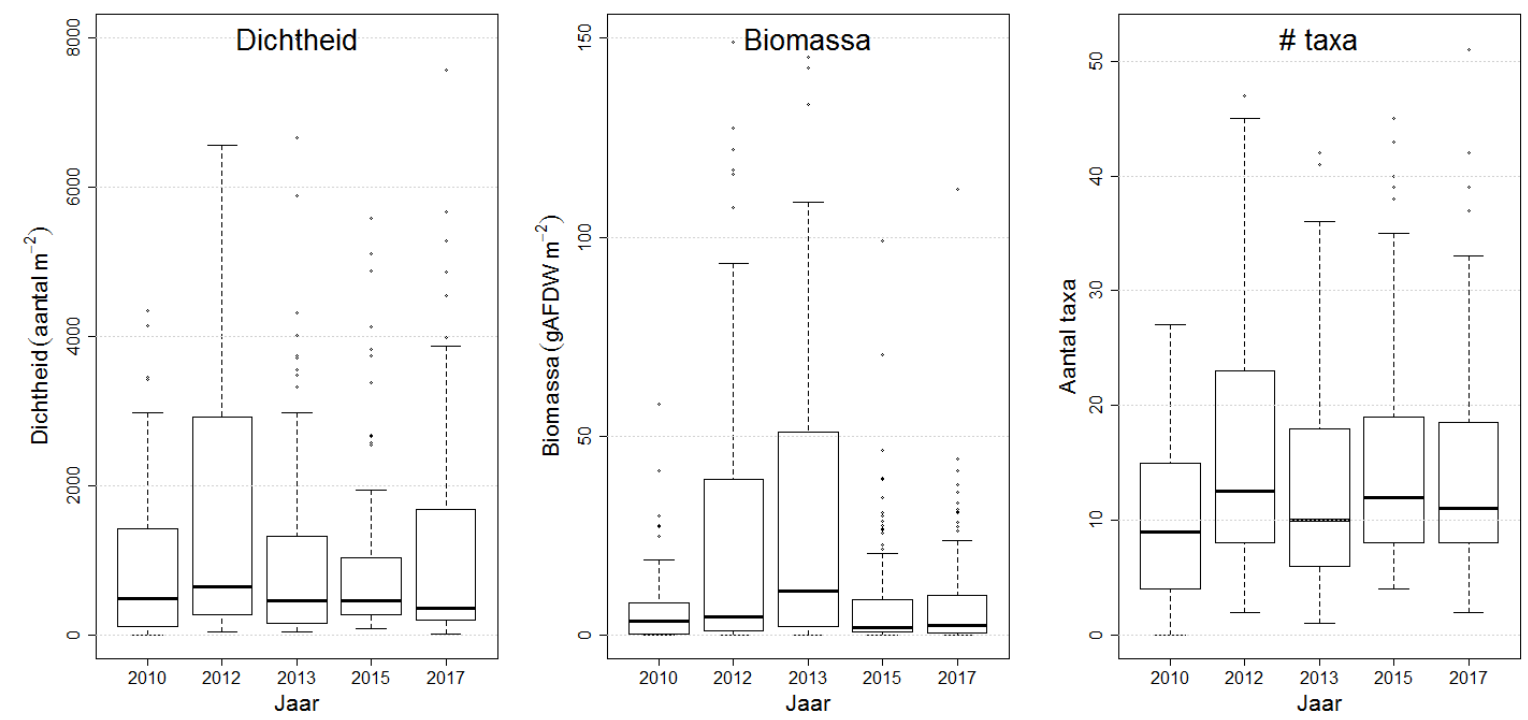

Figuur 37: Boxplots van dichtheid (aantal $\mathrm{m}^{-2}$ ), biomassa ( $\mathrm{g}$ AFDW $\mathrm{m}^{-2}$ ) en het aantal taxa per locatie over de jaren 2010 tot en met 2017 in de Van Veen bemonstering. Voor de overzichtelijkheid van de figuur zijn de y-assen voor dichtheid en biomassa afgebroken bij respectievelijk 8000 en 150.

In totaal zijn er in 2017162 taxa aangetroffen in de monsters. 47 van deze taxa zijn slechts op 1 station gevonden. In totaal zijn er over alle jaren 238 taxa aangetroffen. In 2017 zijn er op opvallend veel stations Donax vitatus aangetroffen (53.3\% van de bemonsterde stations). In de jaren 2010, 2012, 2013 en 2015 was Donax vitatus op respectievelijk 0, 13.3, 4.1 en 13.3 \% van de bemonsterde stations aangetroffen. Andere soorten die in 2017 veelvuldig zijn aangetroffen zijn Nephtys cirrosa, Magelona johnstoni, Spiophanes bombyx en Spio martinensis (Tabel 6). Soorten die in 2017 relatief weinig zijn aangetroffen zijn Ensis spp., Nephtys en Lanice conchilega. 
Tabel 6: Percentage van de stations dat een taxon is aangetroffen in de Van Veen monsters. In de tabel zijn alleen de taxa aangegeven die in meer dan $25 \%$ van de monsters zijn aangetroffen.

\begin{tabular}{|c|c|c|c|c|c|c|}
\hline Taxon & 2010 & 2012 & 2013 & 2015 & 2017 & Totaal \\
\hline Spiophanes bombyx & 38.7 & 64.2 & 54.6 & 55.8 & 46.7 & 53.4 \\
\hline Ensis spp. & 71 & 69.2 & 71.1 & 34.2 & 22.5 & 50.9 \\
\hline Spio martinensis & 51.6 & 60.8 & 34 & 60 & 40.8 & 49.9 \\
\hline Capitella spp. & 50 & 45 & 22.7 & 29.2 & 34.2 & 35.3 \\
\hline Nephtys spp. & 16.1 & 54.2 & 41.2 & 40.8 & 9.2 & 33.7 \\
\hline Scoloplos armiger & 25.8 & 37.5 & 42.3 & 32.5 & 25.8 & 33.1 \\
\hline Fabulina fabula & 8.1 & 27.5 & 28.9 & 42.5 & 36.7 & 31 \\
\hline Lanice conchilega & 25.8 & 34.2 & 38.1 & 35.8 & 17.5 & 30.4 \\
\hline Nemertea & 27.4 & 45.8 & 19.6 & 28.3 & 27.5 & 30.4 \\
\hline Magelona mirabilis & 33.9 & 20.8 & 26.8 & 44.2 & 25 & 29.9 \\
\hline Spisula subtruncata & 9.7 & 29.2 & 27.8 & 30 & 39.2 & 29.1 \\
\hline Abra alba & 17.7 & 36.7 & 23.7 & 22.5 & 24.2 & 25.8 \\
\hline Gastrosaccus spinifer & 1.6 & 21.7 & 5.2 & 54.2 & 30 & 25.6 \\
\hline Limecola balthica & 1.6 & 28.3 & 15.5 & 37.5 & 30 & 25.2 \\
\hline
\end{tabular}

De borstelworm Magelona johnstoni had in 2017 de grootste gemiddelde dichtheid (gemiddeld 323 ind. $\mathrm{m}^{-2}$ ) (Figuur 38). Ook de schelpdieren Donax vittatus, Spisula subtruncata en Fabulina fabula waren relatief talrijk (gemiddelde dichtheid respectievelijk 99, 92 en 54 individuen $\mathrm{m}^{-2}$ ). Wat betreft biomassa was Spisula subtruncata de meest dominante soort in 2017 (7.8 $\left.\mathrm{g} \mathrm{AFDW} \mathrm{m}^{-2}\right)$. Andere belangrijke soorten qua biomassa zijn Donax vittatus (2.4 $\mathrm{g} \mathrm{AFDW} \mathrm{m}^{-2}$ ) en Ensis spp. (1.1 g AFDW m$\left.{ }^{2}\right)$. Hoewel de dichtheid van Echinocardium cordatum beperkt is $\left(1.6 \mathrm{~m}^{-2}\right)$ hebben ze vanwege hun grootte toch een aanzienlijke bijdrage aan de totale biomassa $\left(0.34 \mathrm{~g} \mathrm{AFDW} \mathrm{m}^{-2}\right)$. 


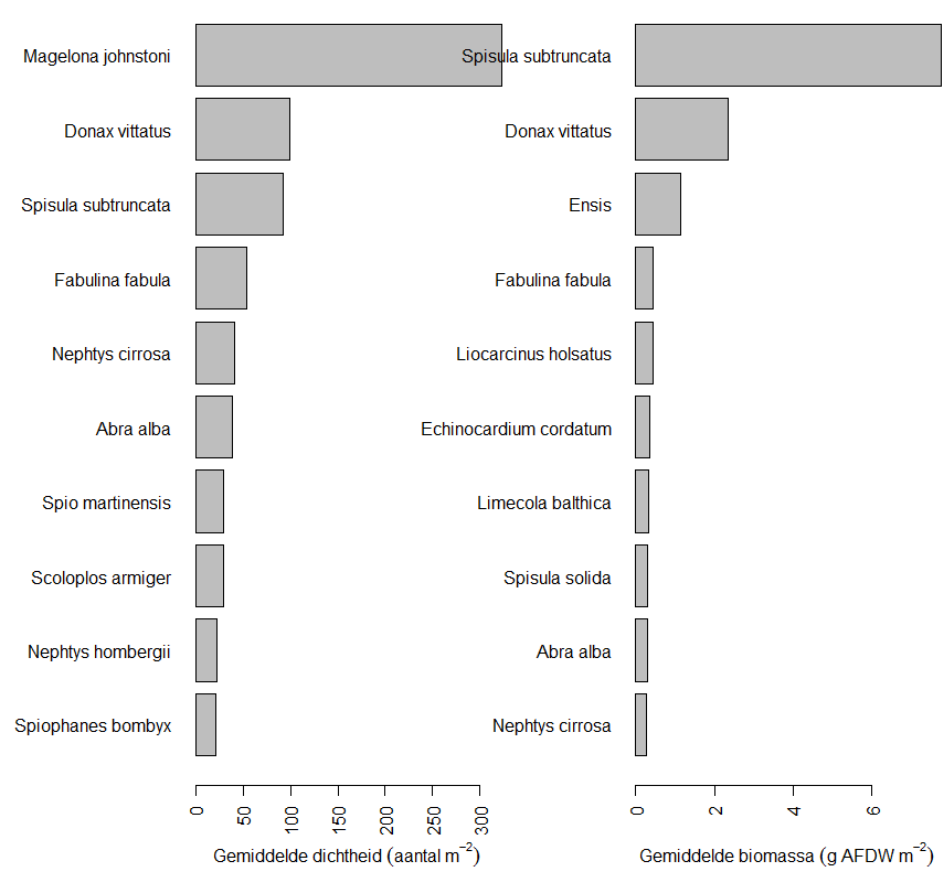

Figuur 38: Gemiddelde dichtheden en biomassa's van de 10 meest dominante soorten bij de bemonstering met de Van Veen happer in 2017.

In Figuur 39 is te zien dat vooral de dichtheden van de soorten Donax vittatus, Spisula subtruncata, Echinocardium cordatum, Spisula solida, Magelona johnstoni, Fabulina fabula en Owenia spp. in 2017 hoger waren dan gemiddeld in 2010 tot en met 2015 en ook hoger dan in 2015. De soorten Liocarcinus vernalis, Diastylis spp., Ensis spp., Mytilus edulis en Laniche conchilega kwamen relatief in lagere dichtheden voor dan gemiddeld in de jaren 2010 - 2015.

2017 - gemiddeld over 2010-2015

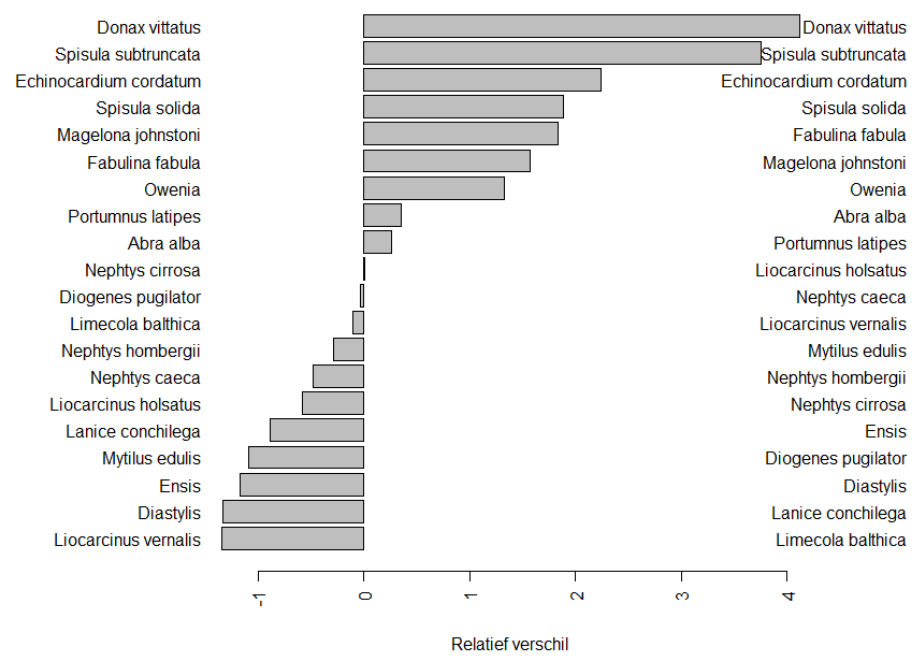

$2017-2015$

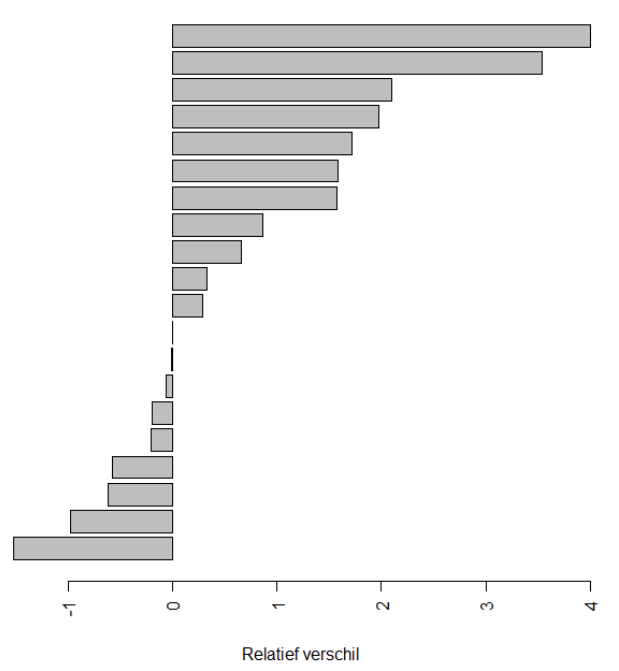

Figuur 39: Relatieve veranderingen in gemiddelde dichtheden van de 20 meest dominante soorten qua dichtheid. In de linker figuur is de gemiddelde dichtheid in 2017 vergleken met de gemiddelde dichtheid over de periode $2010-2015$. In de rechter figuur is het verschil in dichtheid weergegeven tussen 2017 en 2015. De verschillen zijn gewogen naar de gemiddelde dichtheid per soort over alle jaren. 


\subsubsection{Relatie met waterdiepte}

In Figuur 40 is te zien dat er een duidelijk effect is van diepte op zowel de dichtheid, biomassa als het aantal taxa. De dichtheid neemt sterk toe bij dieptes groter dan - 5 meter NAP en de biomassa neemt al toe bij dieptes groter dan -3 meter NAP. Het aantal soorten neemt vrijwel lineair toe met de waterdiepte.
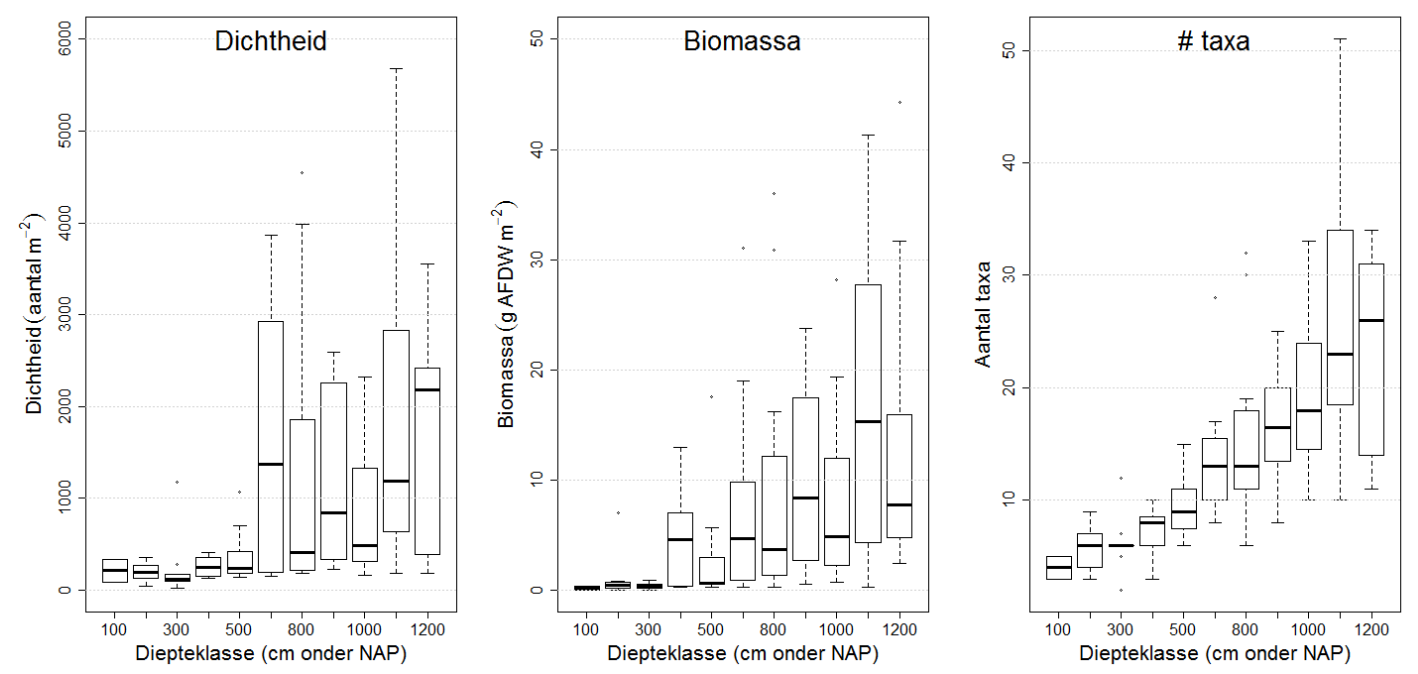

Figuur 40: Boxplots van dichtheid (aantal $\mathrm{m}^{-2}$ ), biomassa $\left(\mathrm{g} \mathrm{AFDW} \mathrm{m} \mathrm{m}^{-2}\right.$ ) en aantal taxa in 2017 als functie van de waterdiepte.

Het GAM-model laat een lineaire relatie zien tussen de waterdiepte en de vierdemachtswortelgetransformeerde dichtheid aan bodemdieren (Figuur 41). De punten geven de geaggregeerde (gemiddeld over de diepteklassen) waarden weer, terwijl het GAM-model is gebaseerd op de individuele metingen. De lineaire toename van de vierdemachtswortel-getransformeerde dichtheid met de waterdiepte is niet in elk individueel transect terug te vinden. De dichtheden op de transecten 3,6, 7, 8 en 12 vertoonden geen significante relatie met de waterdiepte (Figuur 42). Op transecten 1, 210 en 11 was er een lineaire relatie tussen de vierdemachtswortel getransformeerde dichtheid en de waterdiepte en op de transecten 0, 5 en 9 was deze relatie niet-linear. In Figuur 43 zijn de GAM modellen gepresenteerd met jaar als co-variabele. Vooral in de meest zuidelijke transecten ( 0 tot en met 5) is er een duidelijk effect van de jaren, waarbij vooral 2012 afweek van de overige jaren op basis van hogere dichtheden over de hele diepterange. Op de overige transecten (m.u.v. transect 9) is er geen significant verschil tussen de jaren. 


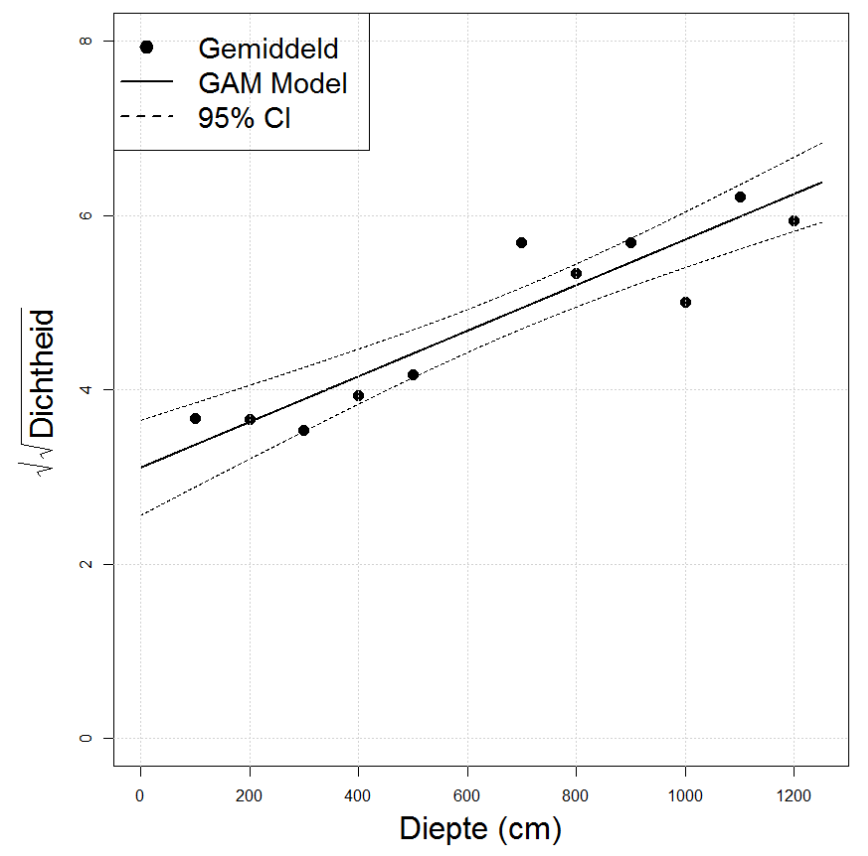

Figuur 41: Vierdemachtswortel-getransformeerde dichtheid (aantal $\mathrm{m}^{-2}$ ) als functie van de diepte (centimeter beneden NAP) van het benthos verzameld met de Van Veen happer. getrokken lijn geeft het resultaat van het GAM model als functie van de diepte en de stippellijnen geven de 95\%-betrouwbaarheid intervallen weer. Het model is gefit op individuele metingen, voor de overzichtelijkheid geven de punten de geaggregeerde data weer.
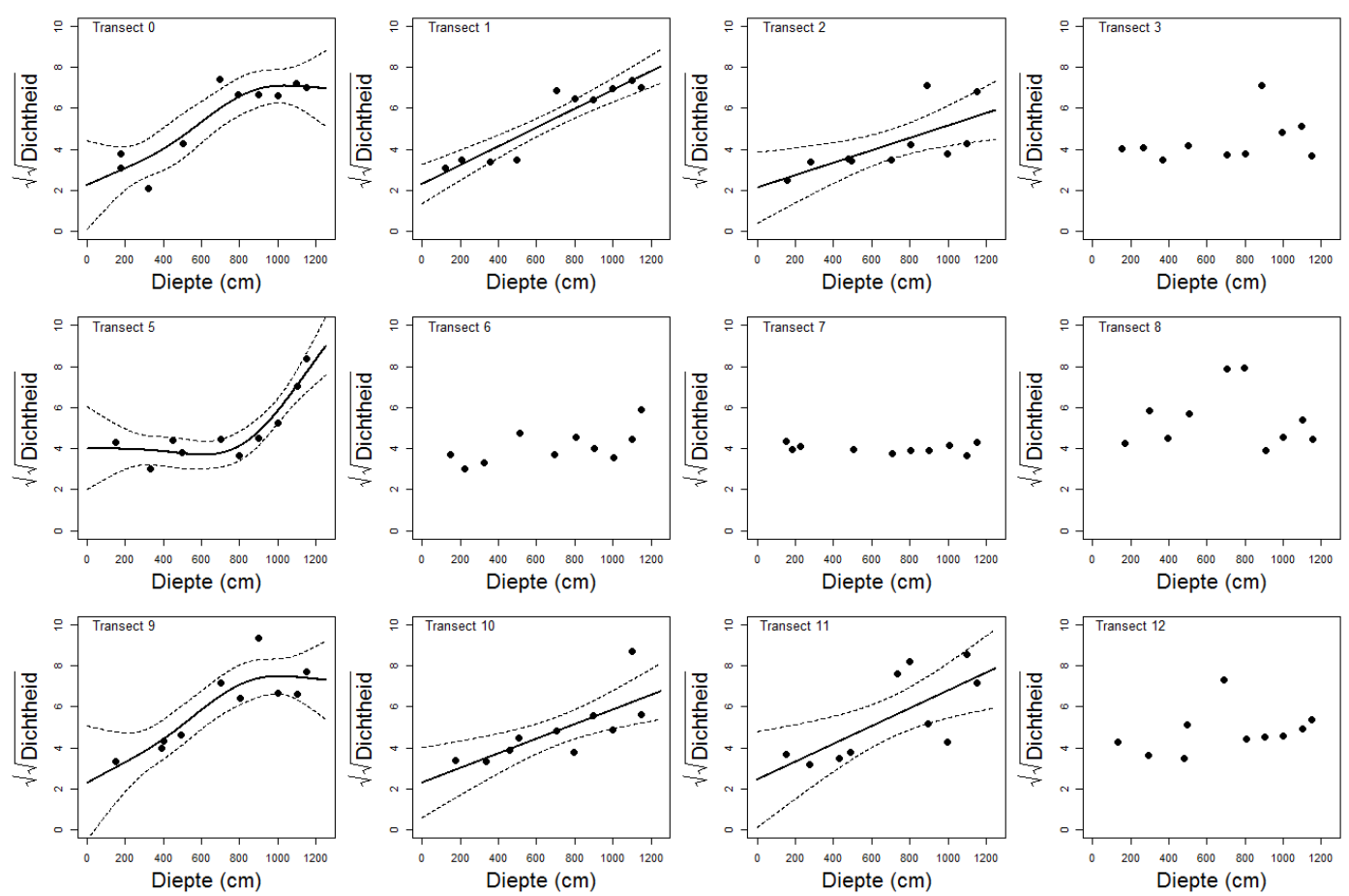

Figuur 42: GAM regressiemodellen voor de vierdemachtswortel-getransformeerde dichtheid als functie van de waterdiepte ( $\mathrm{cm}$ beneden NAP) voor de 12 transecten. Alleen de significante GAM modellen zijn geplot. 

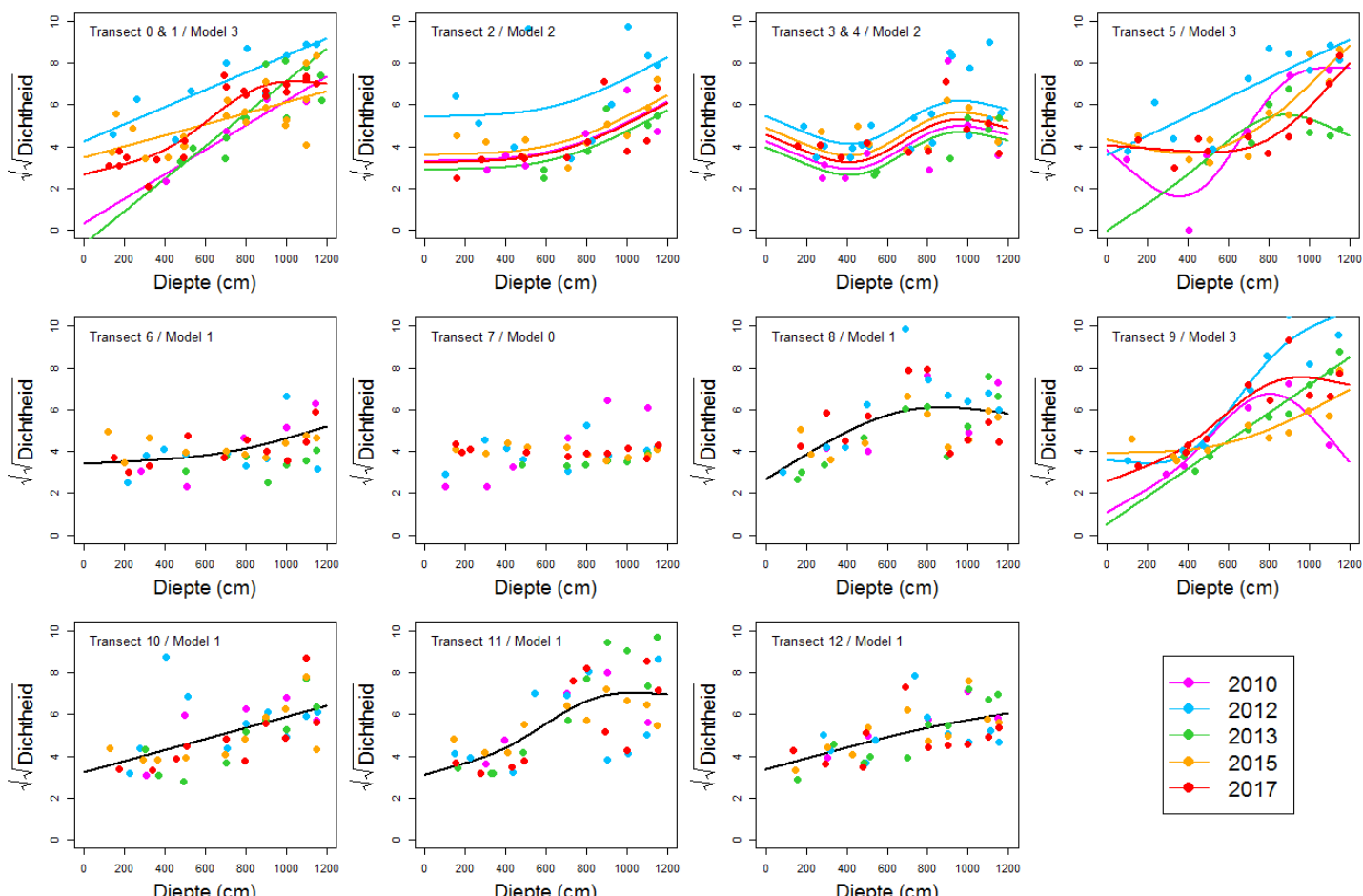

Figuur 43: GAM modellen van de vierdemachtswortel-getransformeerde dichtheid bodemdieren (aantal $\mathrm{m}^{-2}$ ) als functie van de diepte ( $\mathrm{cm}$ beneden NAP) met jaar als factor voor de verschillende transecten. Bij Model 1 (getrokken zwarte lijnen) is er geen significant verschil tussen de jaren. Bij model 2 is er wel een significant verschil tussen de jaren, maar is er geen verschil in het patroon met de diepte. Bij model 3 is er ook een significant verschil in het patroon met de diepte tussen de verschillende jaren. Bij Model 0 is er geen significante relatie.

\subsubsection{Relatie met sedimentsamenstelling}

$\mathrm{Er}$ is een duidelijke relatie tussen het voorkomen van bodemdieren in de Van Veen monsters en de sedimentsamenstelling. In Figuur 44 zijn de dichtheid, biomassa en het aantal soorten uitgezet tegen de mediane korrelgrootte. De hoogste biomassa's en dichtheden worden aangetroffen bij een mediane korrelgrootte van minder dan $300 \mu \mathrm{m}$. Zoals eerder is aangetoond (Figuur 11) is de mediane korrelgrootte ook sterk gecorreleerd met de waterdiepte.
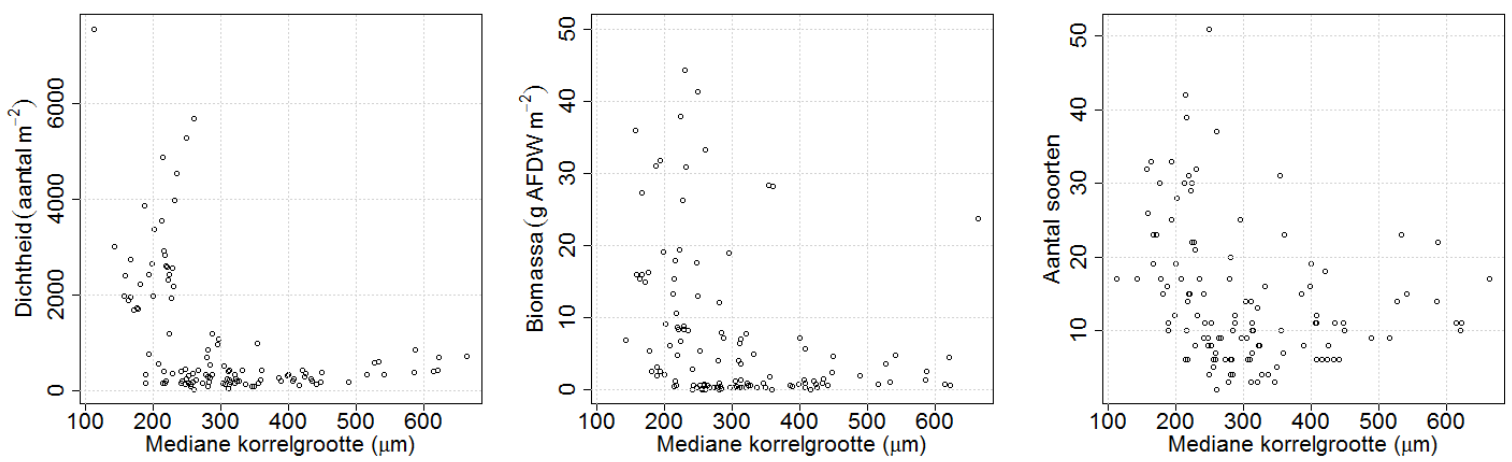

Figuur 44: Relatie tussen dichtheid, biomassa en aantal soorten per locatie op de verticale as en mediane korrelgrootte op de horizontale as voor de Van Veen bemonstering in 2017. De y-as van biomassa is afgekapt bij $50 \mathrm{~g} \mathrm{AFDW} \mathrm{m}^{-2}$. Twee waarden waren aanzienlijk hoger. 


\subsubsection{Ruimtelijke verspreiding}

Ook in Figuur 45 is te zien dat de dichtheid en biomassa aan bodemdieren in de ondiepe delen van het onderzoeksgebied laag zijn. De hogere waarden worden gevonden verder van het strand vandaan. De biomassa van bodemdieren op de kop en iets ten zuiden van de kop van de Zandmotor (transecten 3, 5, 6 en 7) zijn laag. Hogere dichtheden worden aangetroffen ten noorden van de Zandmotor en op de twee meest zuidelijke transecten. Opvallend is dat er een station uitspringt qua biomassa. Dit is station 2017_087, waar heel veel Spisula subtruncata is aangetroffen (6750 ind. $\mathrm{m}^{-2} \mathrm{met}$ een biomassa van $834 \mathrm{~g} \mathrm{AFDW} \mathrm{m}^{-2}$ ). Dit komt overeen met de resultaten uit de bemonstering met de bodemschaaf. Op de locatie 2017_086 is Spisula subtruncata aangetroffen met een dichtheid van 800 $\mathrm{m}^{-2}$ en op 2017_087 met een dichtheid van ruim $2300 \mathrm{~m}^{-2}$. Dat deze getallen iets lager zijn dan de Van Veen happer kan het gevolg zijn van het grotere bemonsterd oppervlak met de bodemschaaf.

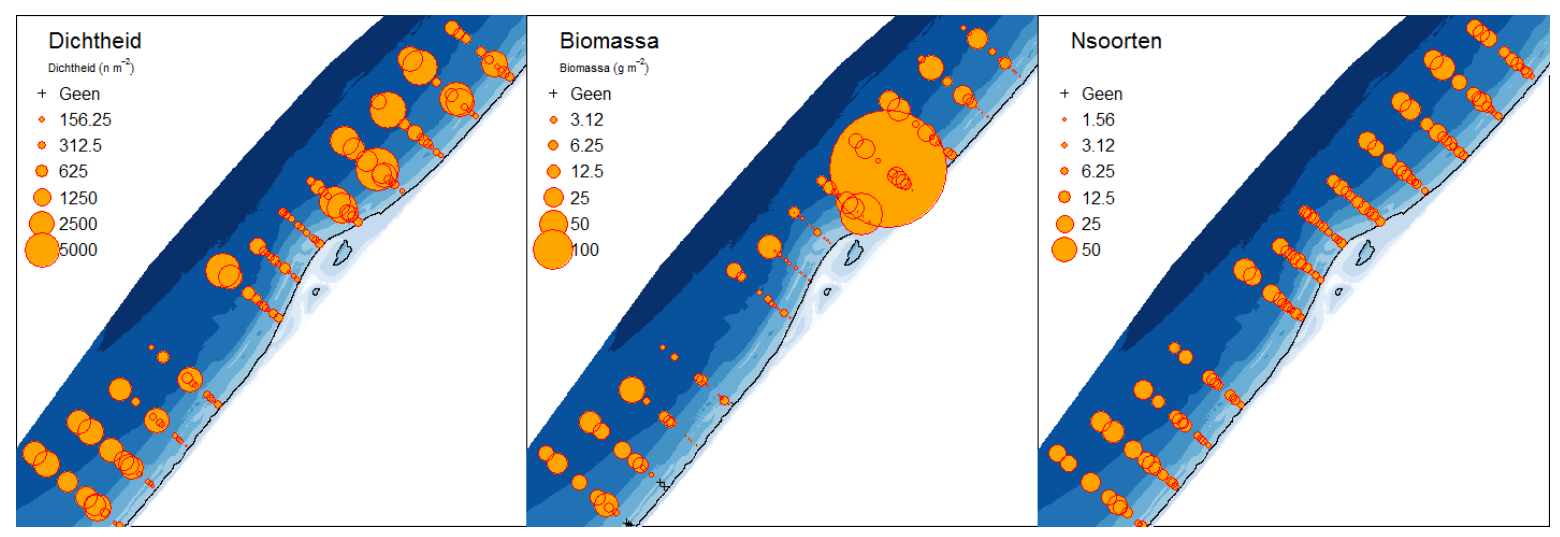

Figuur 45: Verspreidingskaart totale dichtheid (aantal $\mathrm{m}^{-2}$ ), en bodemdierbiomassa ( $\mathrm{g} \mathrm{AFDW} \mathrm{\textrm {m } ^ { - }}$ ${ }^{2}$ ) een aantal soorten per monster in de Van Veen bemonstering 2017.

In Figuur 46 zijn de dichtheden, biomassa's en het aantal soorten voor de Van Veen bemonstering in 2017 uitgezet voor de verschillende transecten. De transecten 2 tot en met 7 en 12 zijn relatief laag in dichtheid en biomassa, terwijl de transecten 0, 1 en 9 een relatief hoge dichtheid en biomassa hebben. Ook het aantal taxa dat is aangetroffen is relatief laag op de transecten op en ten zuiden van de Zandmotor (transecten 2 tot en met 8).
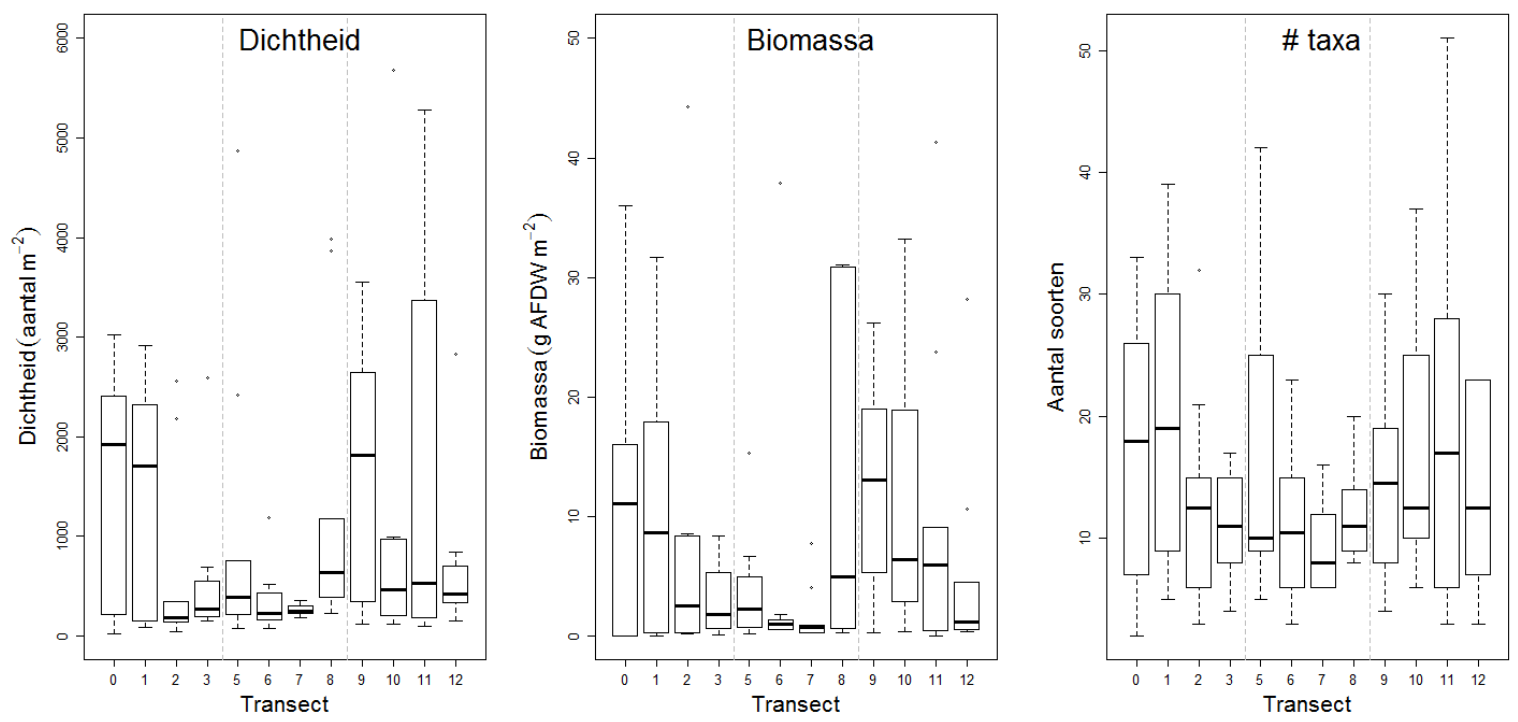

Figuur 46: Boxplots van dichtheid (aantal $\mathrm{m}^{-2}$ ), biomassa $\left(\mathrm{g} \mathrm{AFDW} \mathrm{m}^{-2}\right.$ ) en aantal soorten in 2017 over de verschillende transecten van het meest zuidelijke (transect 0 ) naar het meest noordelijke (transect 12). De verticale stippellijnen geven de scheiding tussen de verschillende deelgebieden. 
In Figuur 47 is de verspreiding van de totale dichtheid aan bodemdieren (aantal $\mathrm{m}^{-2}$ ) in de Van Veen bemonstering uitgezet voor de verschillende jaren. De figuur laat zien dat 2010 een relatief arm jaar is en 2012 juist een rijk jaar wat betreft de dichtheid aan bodemdieren. Over de tijd lijkt er een ruimtelijke ontwikkeling op te treden waarbij de dichtheden van bodemdieren op de transecten op en ten zuiden van de Zandmotor (transecten 3, 5, 6 en 7) afnemen. In Bijlage 7 zijn dezelfde figuren gemaakt voor een aantal specifieke soorten. Zo is te zien dat het zaagje, dat in 2017 massaal is aangetroffen in 2010 helemaal niet is aangetroffen en in 2013 slechts op een 4-tal locaties (Figuur 73). Scolelepis (Scolelepis) squamata is een soort die voornamelijk in de dynamische ondiepe gebieden voorkomt (Figuur 78). Deze soort is ook een van de belangrijkste soorten (in voorkomen) op het strand. In Figuur 48 is het aantal taxa per locatie weergegeven over de verschillende jaren. In deze figuren is ook de toename in diversiteit met de diepte te zien. Ook is te zien dat de stations op de kop van de Zandmotor (transecten 6 en 7) relatief arm zijn qua aantal soorten dat er wordt aangetroffen.

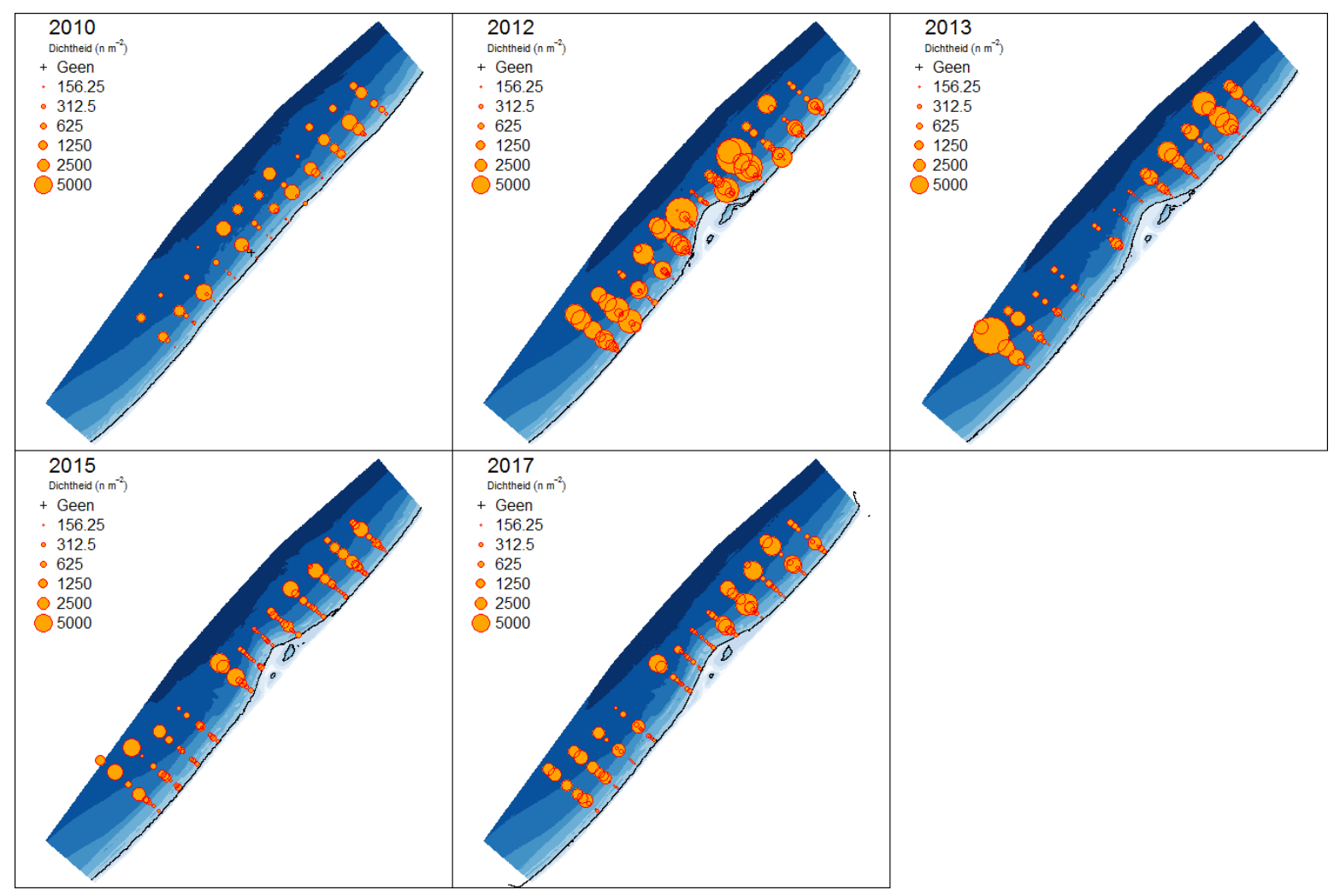

Figuur 47: Verspreidingskaart totale bodemdierdichtheid (aantal $\mathrm{m}^{-2}$ ) bemonsterd met de Van Veen happer in 2010, 2012, 2013, 2015 en 2017. 


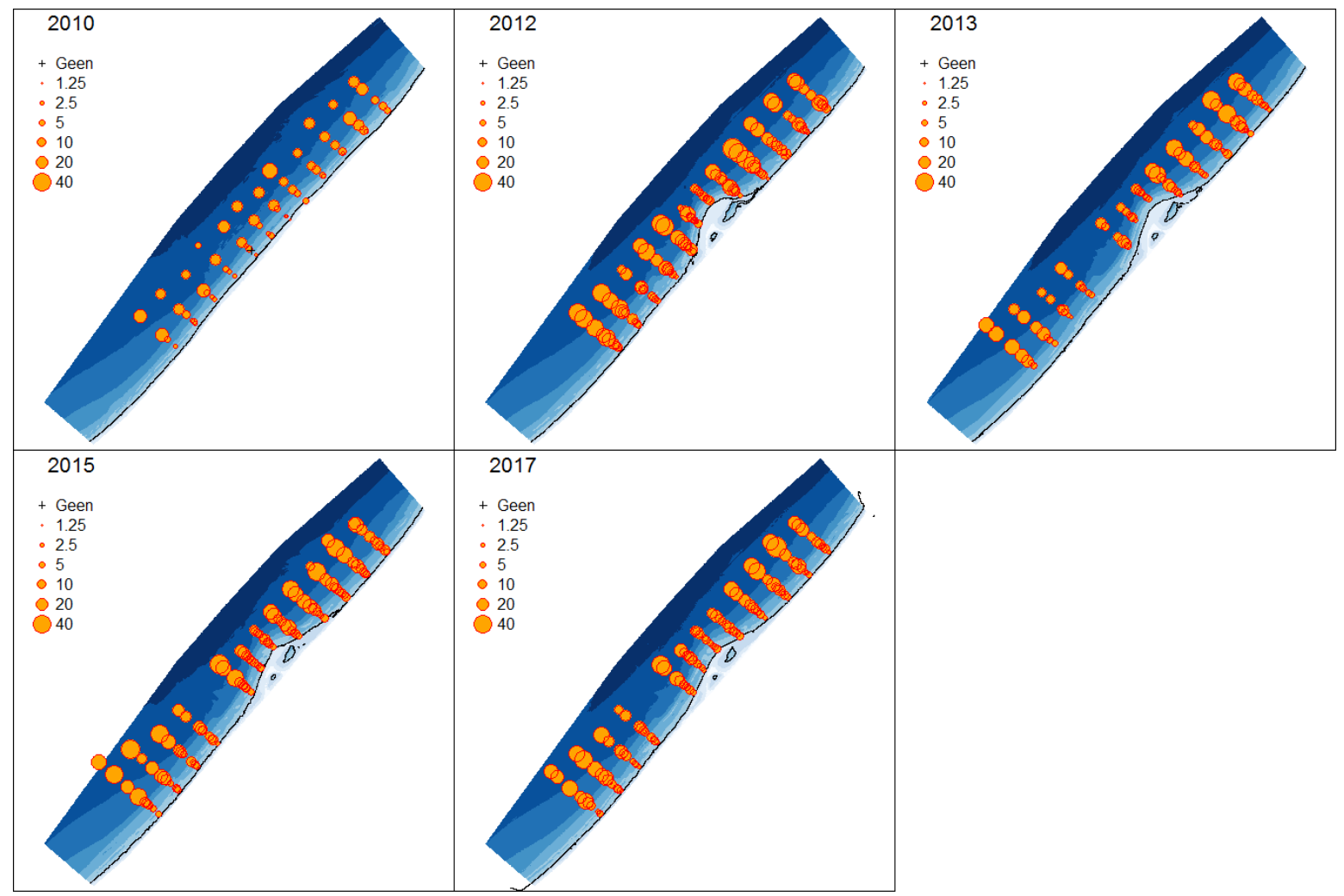

Figuur 48: Verspreidingskaart aantal taxa per locatie $\left(\# \mathrm{~m}^{-2}\right)$ bemonsterd met de Van Veen happer in 2010, 2012, 2013, 2015 en 2017.

\subsubsection{Multivariate analyses}

De clusteranalyse op de data van 2017 resulteerde in 8 significante clusters (Figuur 49). Cluster a is een groot cluster van 38 stations die allemaal zijn gelegen in de ondiepe brandingszone (Figuur 50). Deze stations liggen allen op een diepte van 5 meter of minder beneden NAP en op de kop van de Zandmotor (transecten 6 en 7) op grotere diepten. Dit cluster vertoont overeenkomsten met de stations uit cluster $b$ van de bodemschaafbemonstering (Figuur 31 ). De stations van cluster b (32 stations) bevinden zich net op iets grotere diepten dan de stations van cluster a. De 7 stations van cluster e (donkergroene bolletjes) liggen weer op grotere diepten dan de clusters a en b. De stations van cluster c liggen voornamelijk op de diepste stations (dieper dan -10 meter NAP). De stations van cluster $d$ bevinden zich op de transecten 0,1 en 2 op een diepte tussen de -8 en -10 m NAP. De ligging van de stations komt overeen met de ligging van de stations binnen cluster $f$ van de bodemschaafbemonstering. De stations van cluster $\mathrm{g}$ en $\mathrm{h}$ liggen voornamelijk in het noordelijk gebied (transecten 11 en 12) en vertonen ruimtelijk overeenkomsten met cluster $\mathrm{c}$ uit de bodemschaafbemonstering (Figuur 31). 


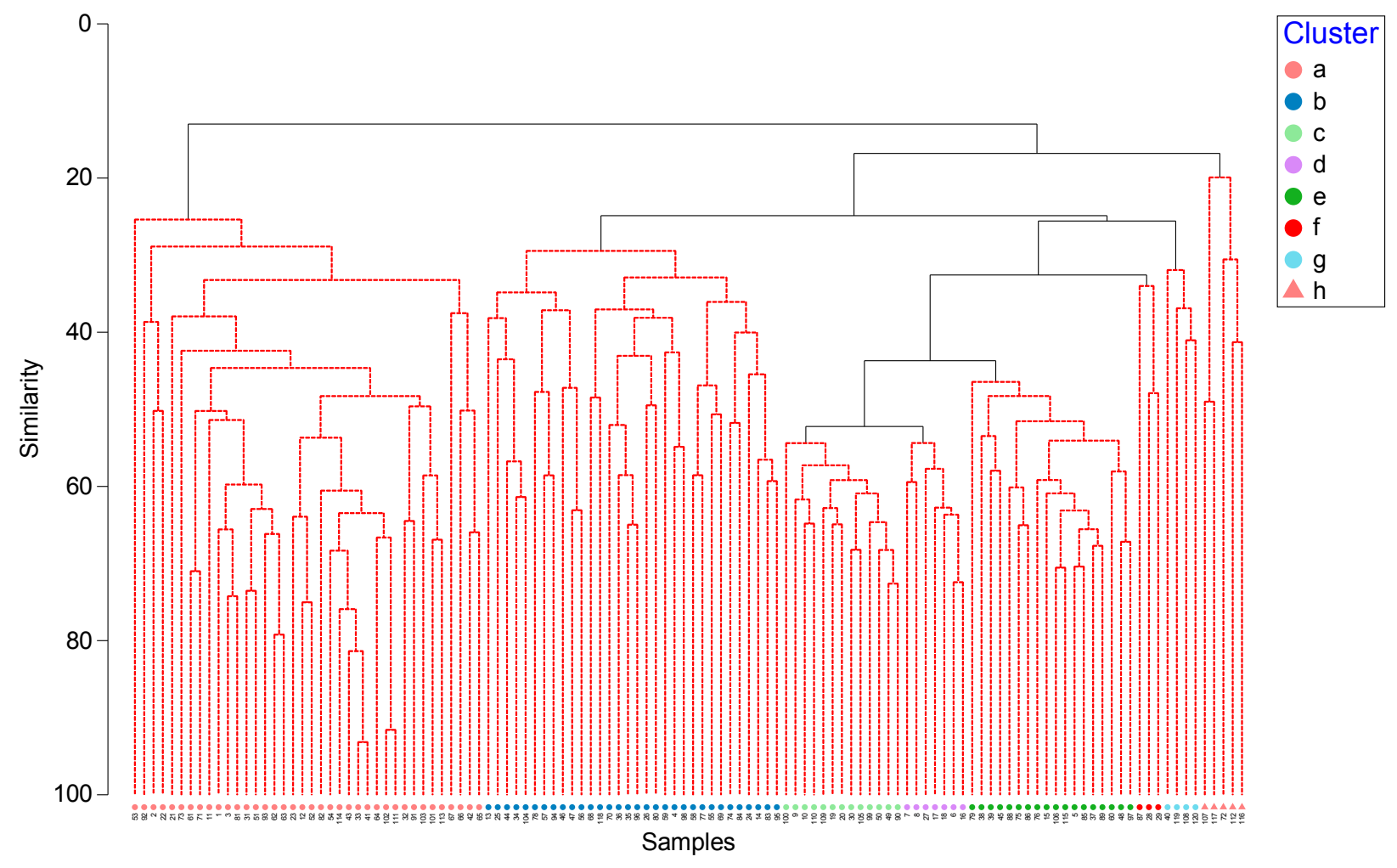

Figuur 49: Clusterdiagram van bodemdieren in de Van Veen bemonstering in 2017. De zwarte lijnen geven de significante clusters (Simprof test, $p<0.05$ )

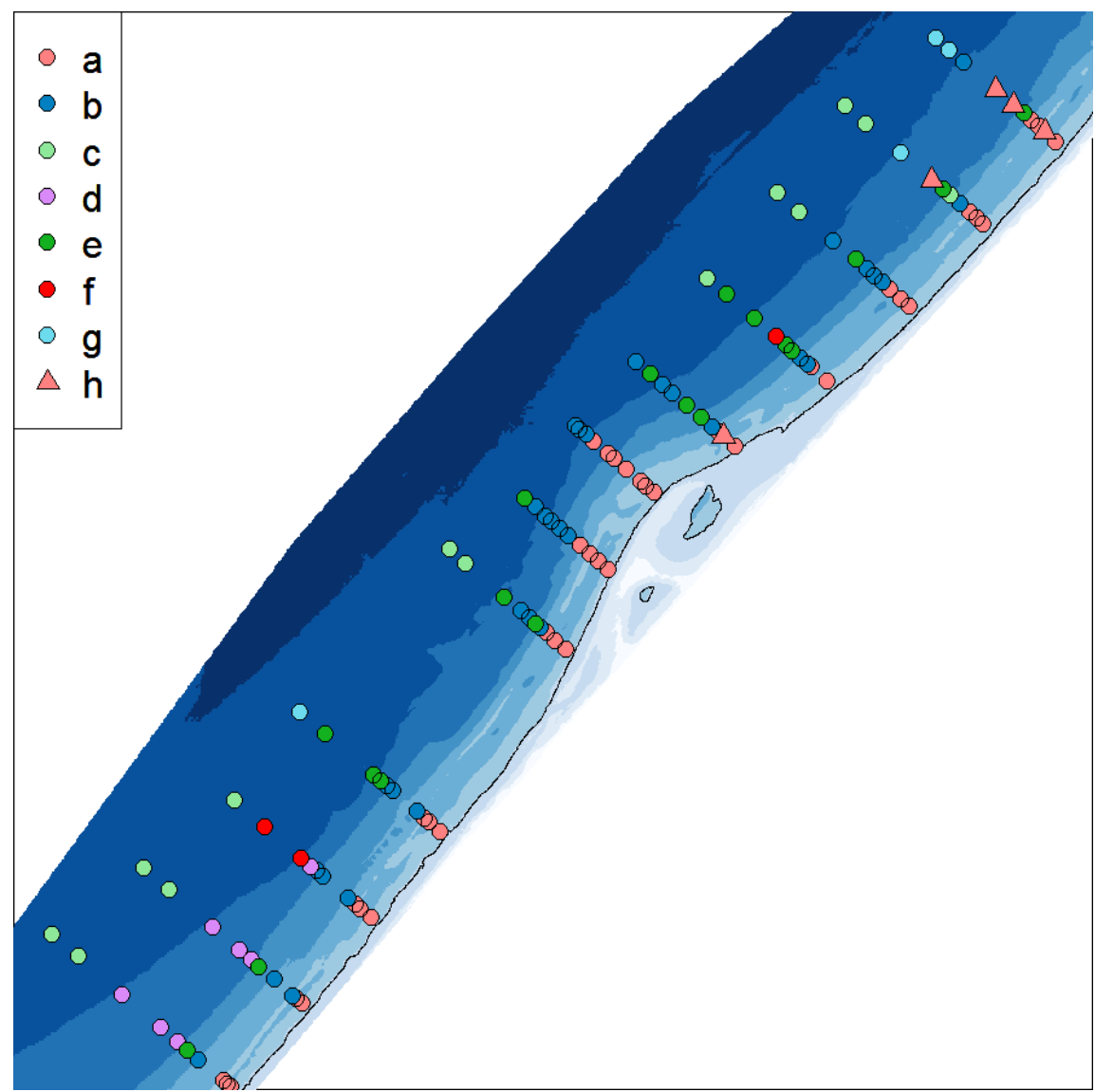

Figuur 50: Verspreidingskaart significante clusters bodemdiergemeenschappen Van Veen bemonstering 2017. De markers corresponderen met de markers uit de clusteranalyse (Figuur 49). 
In Figuur 51 is de nMDS plot, gebaseerd op de data van de Van Veen-bemonstering weergegeven. De markers geven de significante clusters weer uit de clusteranalyse (Figuur 49). In de figuur is duidelijk te zien dat de grote clusters a en b zich ruimtelijk onderscheiden van de clusters $c, d, e, f$ en $g$ op de horizontale as van de nMDS plot. De clusters $\mathrm{g}$ en $\mathrm{h}$ liggen hoger op de verticale nMDS-as. Uit de nMDS plot blijkt ook dat er overeenkomsten zijn in soortensamenstelling tussen de stations uit de clusters c, d en e.

In Figuur 52 is dezelfde nMDS plot weergegeven als in Figuur 51, echter nu zijn met de markers het relatieve aandeel van een 4-tal kenmerkende soorten weergegeven: Scolelepis (Scolelepis) squamata, Nephtys cirrosa., Spisula subtruncata en Capitella spp. Scolelepis (Scolelepis) squamata komt voornamelijk voor op de relatief dynamische stations van clusters a en gedeeltelijk binnen cluster b. Spisula subtruncata komt voor binnen de clusters c, d en e evenals een deel van de stations van cluster b. Nephtys cirrosa is wijd verspreidt over de clusters maar is vooral een belangrijke soort binnen het cluster $b$.

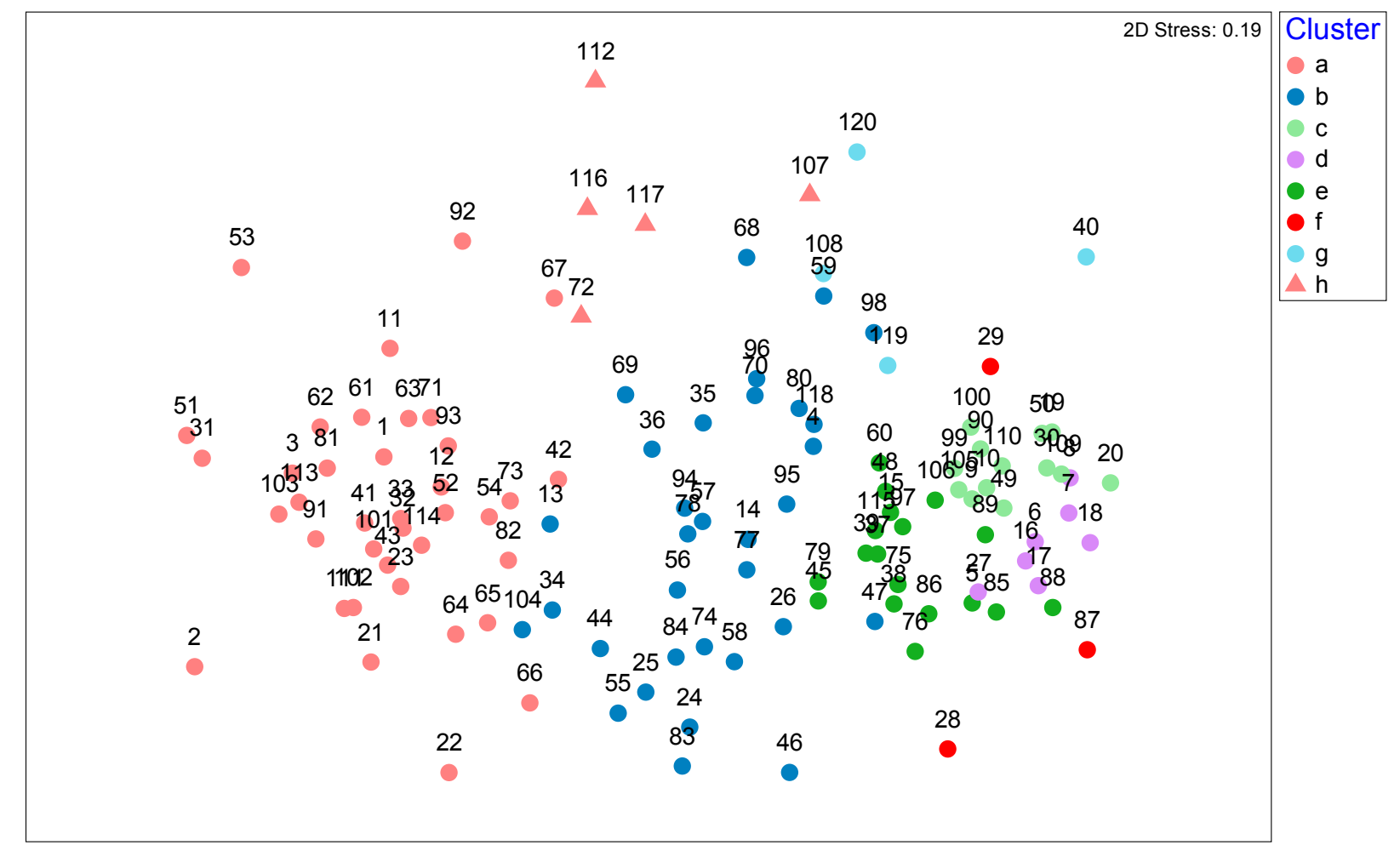

Figuur 51: nMDS plot Van Veen gegevens 2017. De labels geven de nummers van de bemonsteringslocaties weer. De kleur van de markers representeren de clusters uit de clusteranalyse. 


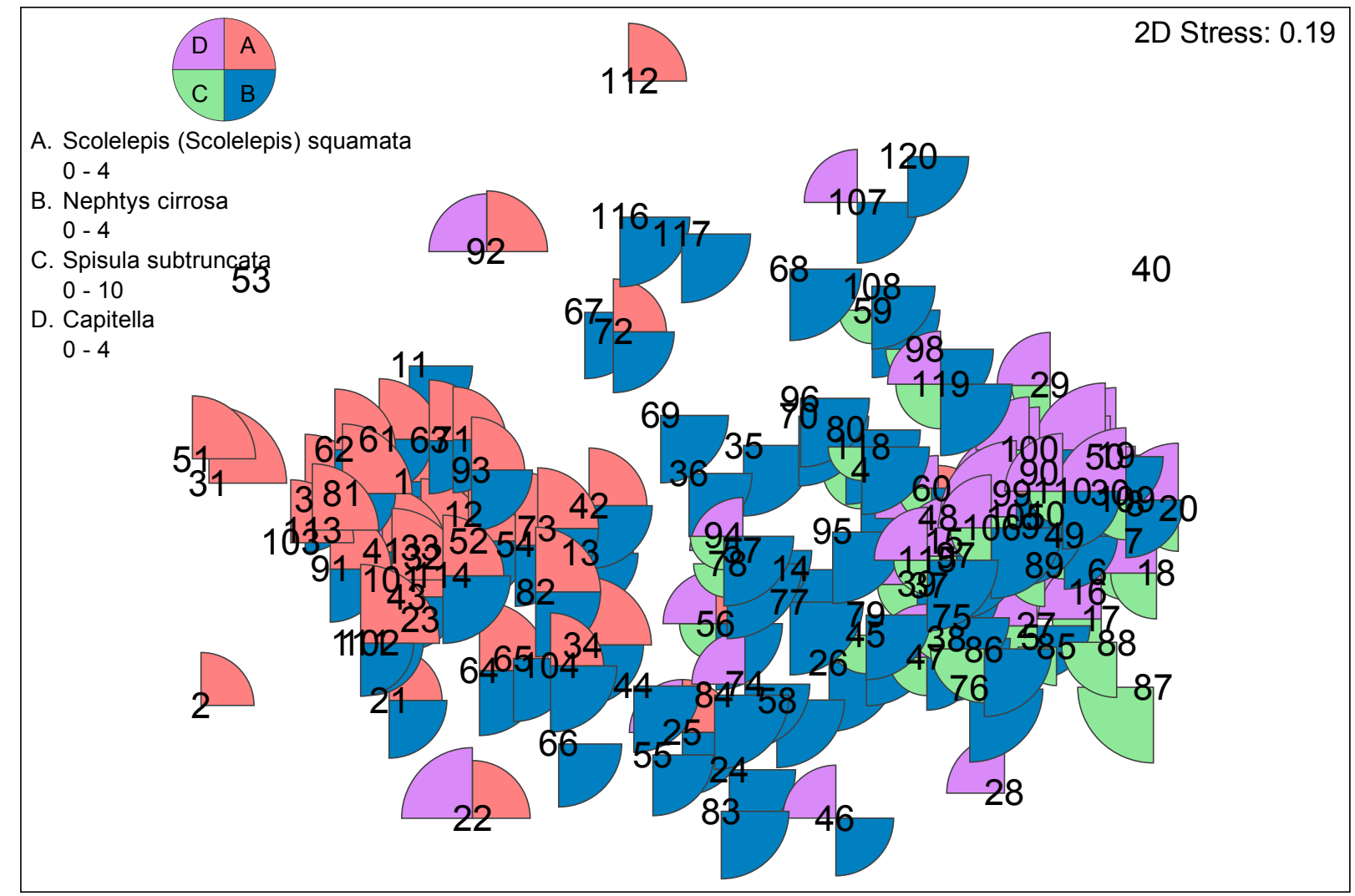

Figuur 52: nMDS plot Van Veen gegevens 2017, als in Figuur 51. De markers geven nu het relatieve aantal van een aantal karakteristieke soorten weer De labels geven de nummers van de bemonsteringslocaties weer. De kleur van de markers representeren de clusters uit de clusteranalyse.

Om de ontwikkeling van de bodemdiergemeenschap in de tijd te visualiseren zijn er niet-metrische MDS plots gemaakt op de geaggregeerde data over alle jaren. De dichtheden zijn hiervoor gemiddeld per jaar en gebied (Figuur 53) en per jaar en dieptestratum (Figuur 54). In de figuur is duidelijk te zien dat de bodemdiergemeenschap in alle drie de gebieden na de aanleg van de Zandmotor anders was dan voor de aanleg (2010). In 2013 is er een duidelijk verschil in bodemdiergemeenschap tussen de gebieden Zuid, Zandmotor en Noord, waarbij vooral het gebied Zandmotor afwijkt van de overige twee. In 2015 is het verschil tussen de gebieden minder, maar in 2017 wijken ze weer van elkaar af. Op basis van deze figuur kan worden geconcludeerd dat de bodemdiergemeenschap zich aan het ontwikkelen is binnen het onderzoeksgebied en dat deze nog niet is teruggekeerd naar de situatie van voor de aanleg. De ontwikkeling binnen de deelgebieden is verschillend over de jaren. 


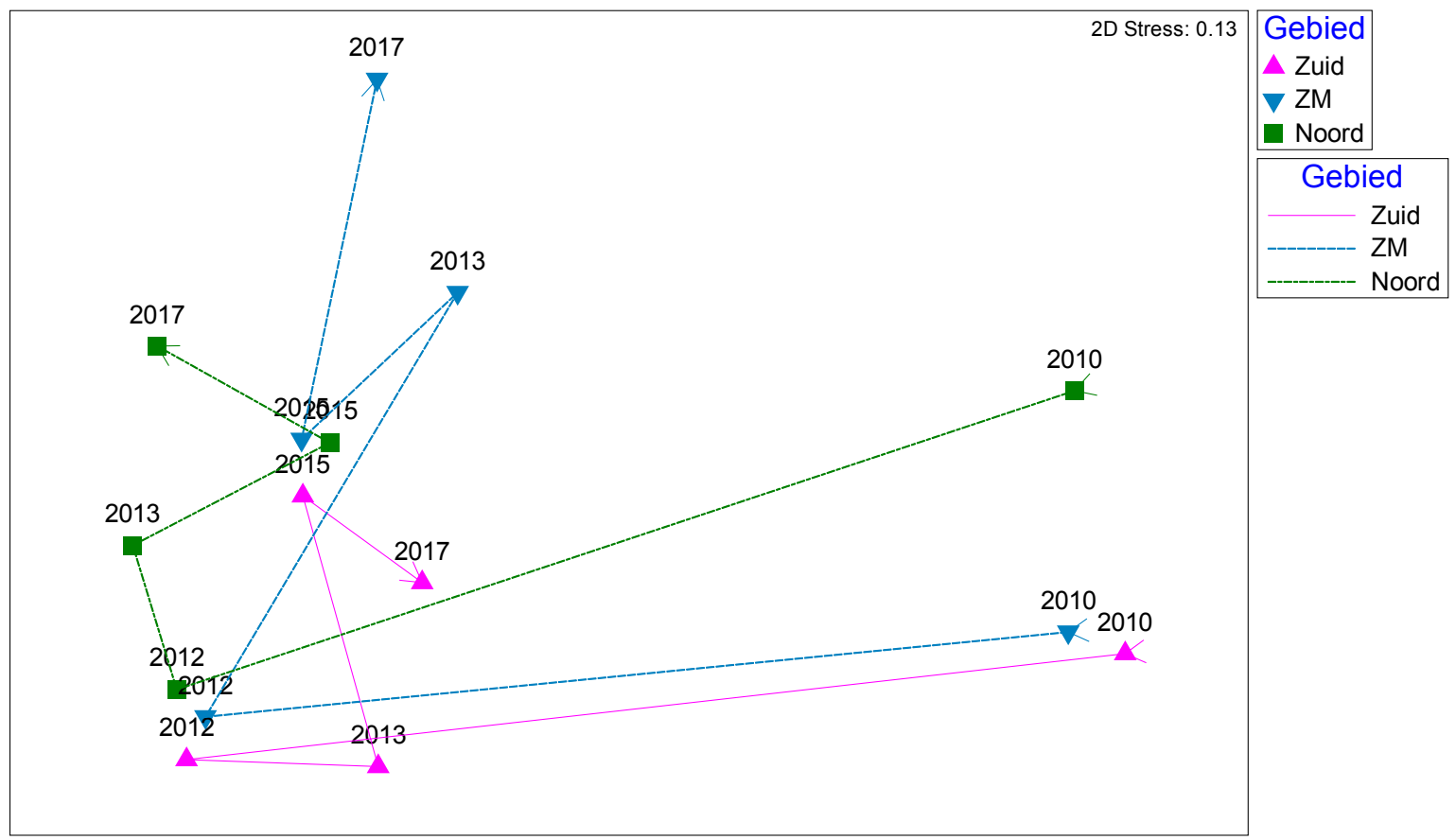

Figuur 53: nMDS plot van de ontwikkeling van de bodemdiergemeenschap over de tijd voor de drie verschillende deelgebieden (Zuid, Zandmotor en Noord) De afstand tussen de punten is een maat voor de dissimilariteit in de bodemdiersamenstelling.

Ook in Figuur 54 is er een duidelijk effect van diepte te zien op de bodemdiergemeenschap over de horizontale as van de nMDS plot. De diepteklassen 1 tot en met 4 (tot een diepte van ongeveer -5 meter NAP) onderscheiden zich duidelijk van de diepteklassen 5 tot en met 10 (vanaf -7 meter NAP). Ook is de ontwikkeling in de tijd te zien over de verticale as van nMDS plot, al is deze minder duidelijk dan bij de data van de bodemschaaf (Figuur 36). De ontwikkeling is niet alleen beperkt tot de ondiepe gebieden, waar het effect van de Zandmotor op de morfologie het grootst is, maar is ook terug te vinden op de grotere dieptes.

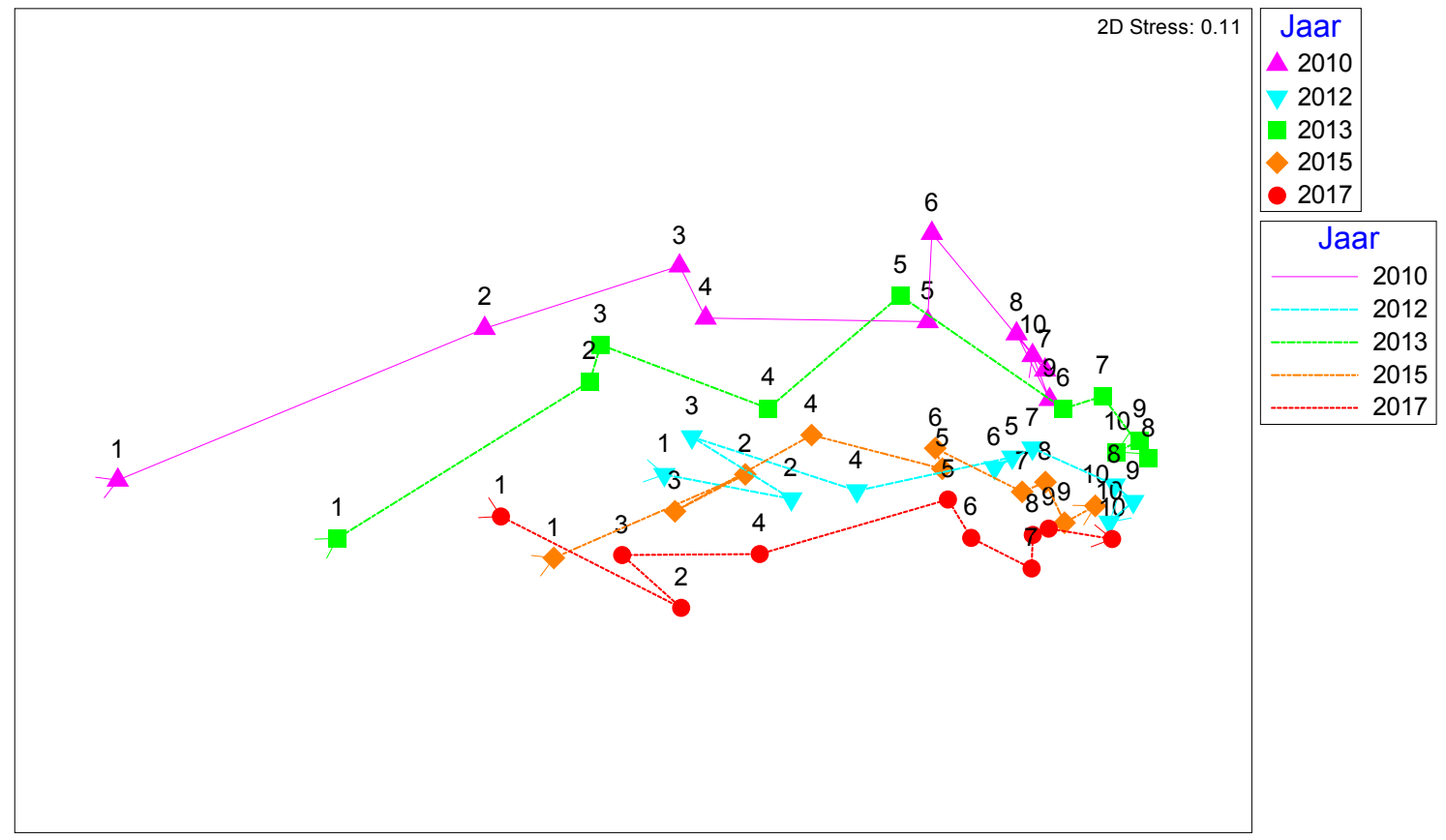

Figuur 54: nMDS plot van de ontwikkeling van de bodemdiergemeenschap als functie van diepte voor de verschillende jaren. De afstand tussen de punten is een maat voor de dissimilariteit in de bodemdiersamenstelling. 


\subsection{Strandbemonstering}

\subsubsection{Overzicht}

In totaal zijn er in 201770 benthosmonsters genomen op het strand. Op 27 stations zijn geen levende bodemdieren aangetroffen. In totaal zijn er 21 taxa aangetroffen. Dit is minder dan in voorgaande jaren. In 2013 en 2015 zijn er nog respectievelijk 39 en 47 taxa in de strandmonsters aangetroffen. Zowel de gemiddelde dichtheid $\left(74 \pm 151\right.$ individuen $\left.\mathrm{m}^{-2}\right)$, biomassa $\left(0.098 \pm 0.29 \mathrm{~g} \mathrm{AFDW} \mathrm{m}^{-2}\right)$ als het aantal taxa per locatie $(1.14 \pm 1.2)$ was lager dan in voorgaande jaren (Figuur 55).
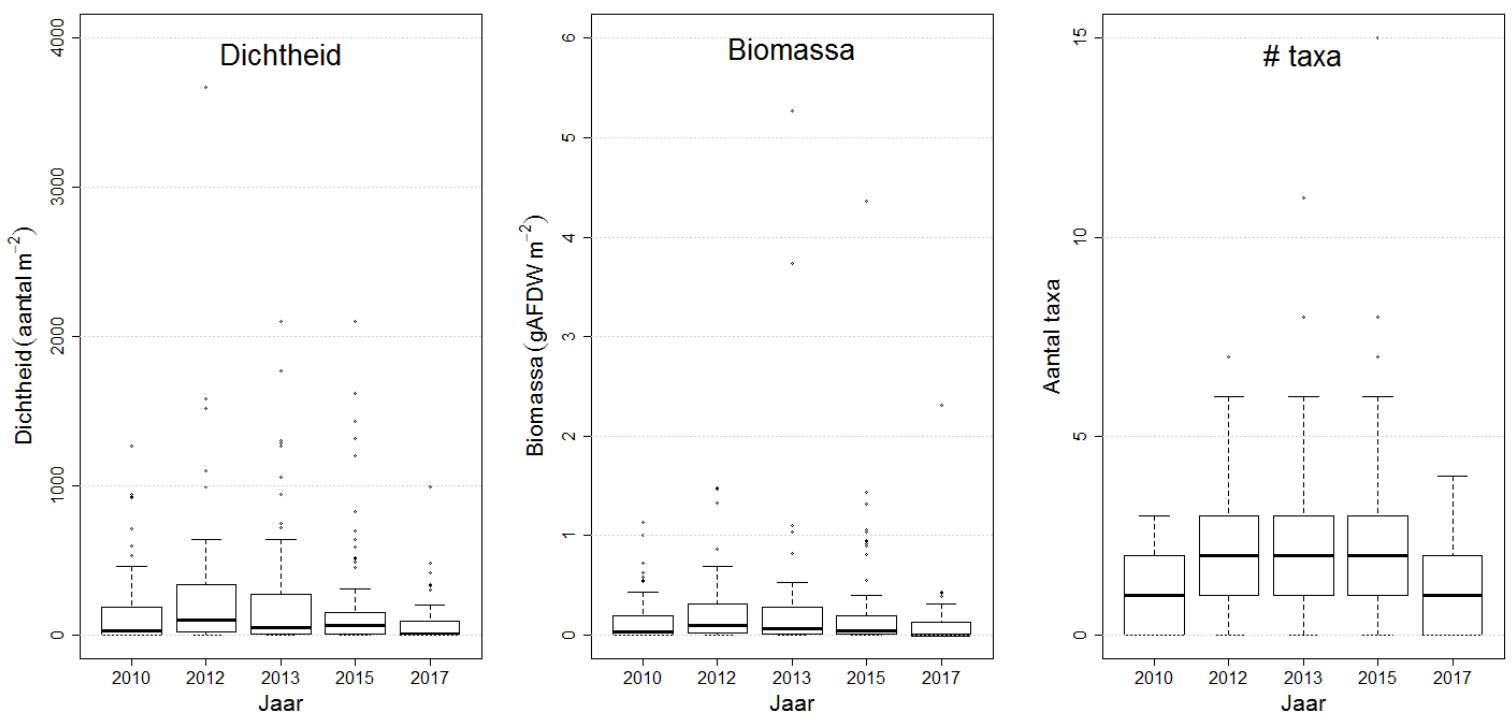

Figuur 55: Boxplots van dichtheid (aantal $\mathrm{m}^{-2}$ ), biomassa ( $\mathrm{g}$ versgewicht $\mathrm{m}^{-2}$ ) en het aantal soorten per locatie voor de strandmonsters over de jaren 2010 tot en met 2017.

De meest voorkomende soorten in de strandmonsters zijn Scolelepis (Scolelepis) squamata, Haustorius arenarius, Eteone spp. en Pontocrates arenarius (Tabel 7). In 2017 was het relatieve voorkomen van deze soorten minder dan gemiddeld in andere jaren. De soort Eurydice pulchra daarentegen is in 2017 relatief vaak aangetroffen in de strandmonsters (10\% van de monsters).

\section{Tabel 7: $\quad$ Relatieve voorkomen (\% van de stations aangetroffen) van de 10 meest voorkomende taxa in de strandmonsters voor de jaren 2010, 2012, 2013, 2015 en 2017.}

\begin{tabular}{|c|c|c|c|c|c|c|}
\hline Taxon & 2010 & 2012 & 2013 & 2015 & 2017 & Totaal \\
\hline Haustorius arenarius & 31.7 & 36.9 & 32.9 & 42.9 & 17.1 & 32.2 \\
\hline Eteone spp. & 0 & 32.3 & 12.9 & 10 & 1.4 & 11.3 \\
\hline Pontocrates arenarius & 0 & 20 & 10 & 18.6 & 4.3 & 10.7 \\
\hline Nemertea & 0 & 4.6 & 7.1 & 8.6 & 0 & 4.2 \\
\hline Capitella spp. & 0 & 3.1 & 5.7 & 2.9 & 7.1 & 3.9 \\
\hline Pygospio elegans & 0 & 4.6 & 4.3 & 5.7 & 1.4 & 3.3 \\
\hline
\end{tabular}

Op basis van dichtheden zijn ook Scolelepis (Scolelepis) squamata en Haustorius arenarius de meest voorkomende soorten in de strandmonsters (Tabel 8). In 2017 zijn de dichtheden over het algemeen minder dan in voorgaande jaren, met uitzondering van de soorten Capitella spp., Eurydice pulchra en Heteromastus filiformis waarvan de dichtheden overeenkwamen met de gemiddelde dichtheid in voorgaande jaren en Polydora cornuta die alleen in 2013 in vergelijkbare dichtheden is aangetroffen. 
Tabel 8: Gemiddelde dichtheden van de meest dominante soorten (gemiddelde dichtheid in alle monsters $>1 \mathrm{~m}^{-2}$ ) die zijn verzameld op het strand over de jaren 2010, 2012, 2013, 2015 en 2017.

\begin{tabular}{|c|c|c|c|c|c|c|}
\hline Taxon & 2010 & 2012 & 2013 & 2015 & 2017 & Totaal \\
\hline Haustorius arenarius & 10.3 & 26.3 & 22.7 & 31 & 11.1 & 20.5 \\
\hline Capitella spp. & 0 & 14.3 & 15 & 4.4 & 6.1 & 8.1 \\
\hline Pontocrates arenarius & 0 & 18 & 7.6 & 7.3 & 0.6 & 6.7 \\
\hline Spiophanes bombyx & 0 & 0 & 0.1 & 20.3 & 0 & 4.3 \\
\hline Eteone spp. & 0 & 6 & 3.1 & 1.6 & 0.1 & 2.2 \\
\hline Eurydice pulchra & 1.5 & 1.5 & 1.1 & 1.1 & 1.3 & 1.3 \\
\hline
\end{tabular}

\subsubsection{Relatie met droogval}

Zowel de dichtheid, biomassa als het aantal aangetroffen taxa van de monsters op het strand heeft een relatie met de droogvalduur. In Figuur 56 zijn er 5 droogvalklassen gedefinieerd, overeenkomend met -5: monsterpunten op de hoogst gelegen delen van het strand (nabij de hoogwaterlijn) en -1 : monsterpunten die het kortste droogvallen (nabij de laagwaterlijn). De armste monsters zijn aangetroffen in droogvalklasse -5 en -4 , hoog in het intergetijdengebied. Deze locaties staan minder $20 \%$ van de tijd onder water. Op droogvalklassen $-3,-2$ en -1 (meer dan $20 \%$ van de tijd onder water) is zowel de dichtheid als biomassa en het aantal aangetroffen taxa aanzienlijk hoger dan op de hoger gelegen delen van het strand. Deze patronen komen overeen met de patronen die eerder zijn gevonden en kan worden toegeschreven aan de moeilijke omstandigheden hoog in het intergetijdengebied voor de mariene organismen (Van Egmond et al., 2018).
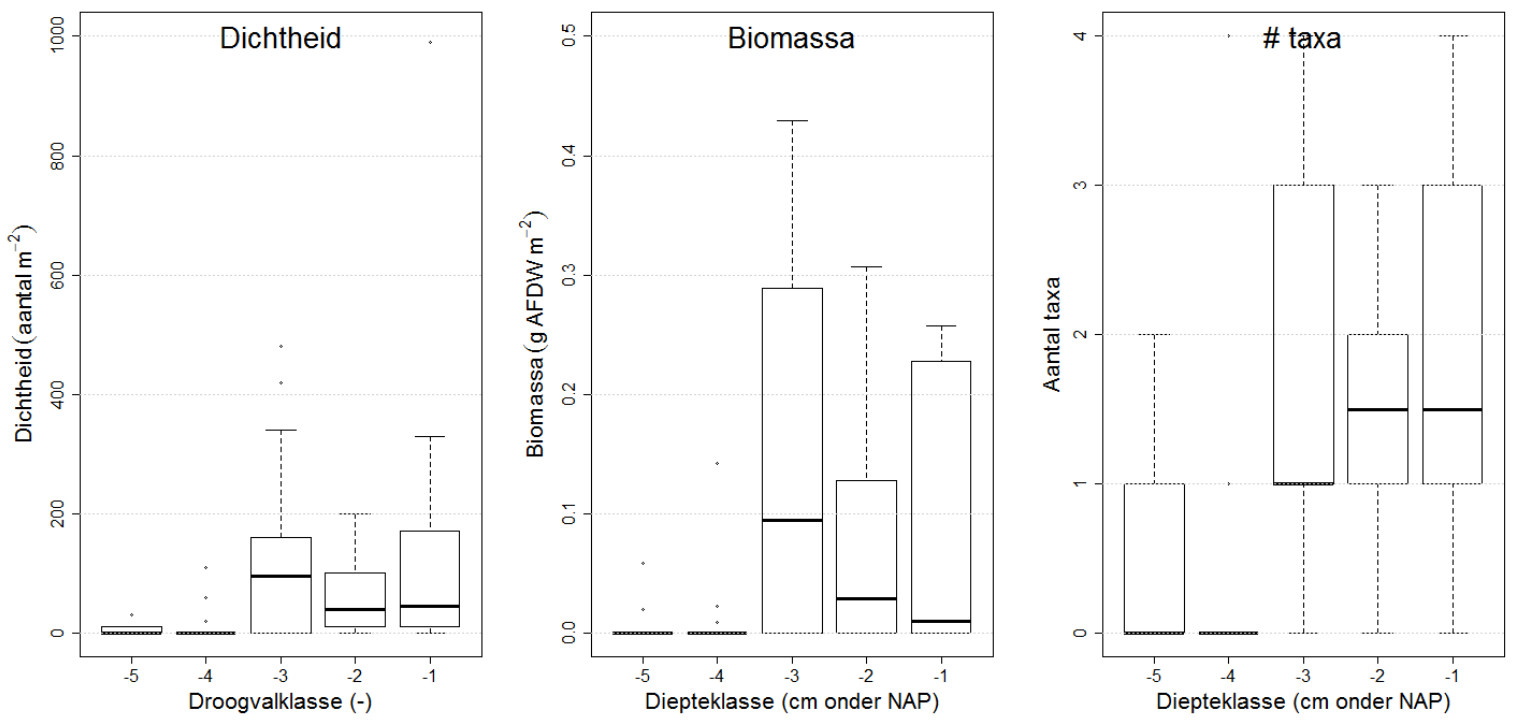

Figuur 56: Boxplots van dichtheid (aantal $\mathrm{m}^{-2}$ ), biomassa ( $\mathrm{g}$ versgewicht $\mathrm{m}^{-2}$ ) en het aantal soorten per locatie voor de strandmonsters in 2017 als functie van de droogvalklasse. 


\subsubsection{Ruimtelijke verspreiding}

In 2017 zijn de hoogste totale dichtheden aan bodemdieren aangetroffen in de zuidelijkste transecten (transecten $0,1,2$ en 3). Ook op het strand langs de zuidkant van de beschutte lagune en op transect 9 was de dichtheid relatief hoog. Lage dichtheden zijn aangetroffen aan de geëxponeerde zijde van de Zandmotor en op de noordelijk gelegen transecten (transecten 10, 11 en 12). Dit patroon is vergelijkbaar met de patronen uit de voorgaande jaren, hoewel de dichtheden toen hoger waren. In 2010, 2012, 2013 en 2015 waren de gemiddelde totale dichtheden respectievelijk 173, 283, 255 en 228 individuen $\mathrm{m}^{-2}$, terwijl de gemiddelde dichtheid in 2017 slechts 74 individuen $\mathrm{m}^{-2}$ was.

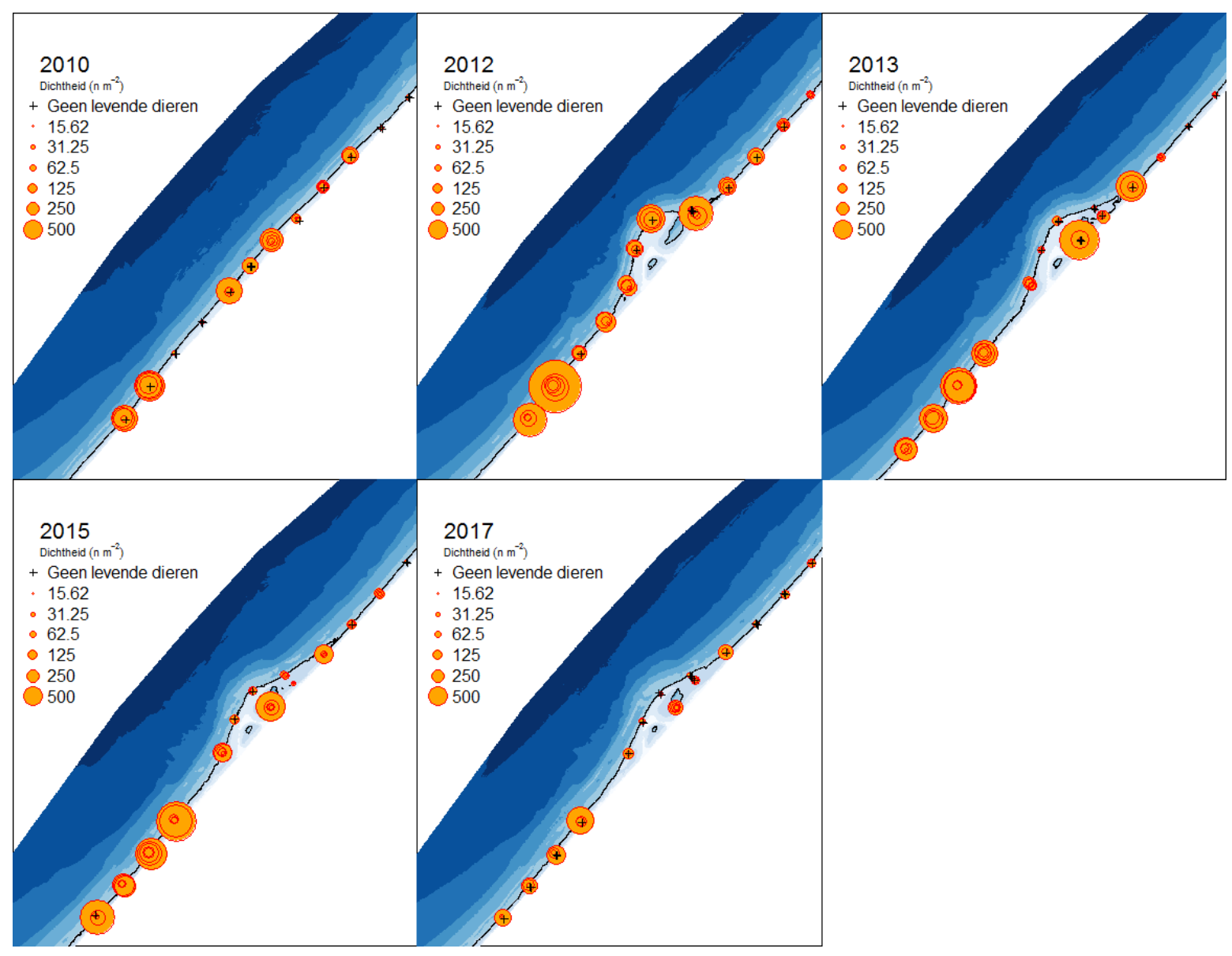

Figuur 57: Ruimtelijke verspreiding van dichtheid (aantal $\mathrm{m}^{-2}$ ) bodemdieren in de strandmonsters over de jaren 2010 tot en met 2017.

De soortensamenstelling op het beschutte strand langs de lagune was anders dan op de overige locaties op de stranden. Soorten als Polydora cornuta, Capitella spp., Heteromastus filiformis, Corophium arenarium, Corophium volutator Pygospio elegans, Monocorophium acherusicum, Peringia ulvae zijn op het strand uitsluitend aangetroffen rond de beschutte lagune. In Figuur 58 is de verspreiding van de soorten Polydora cornuta en Capitella spp. weergegeven voor de strandmonsters uit 2017. 


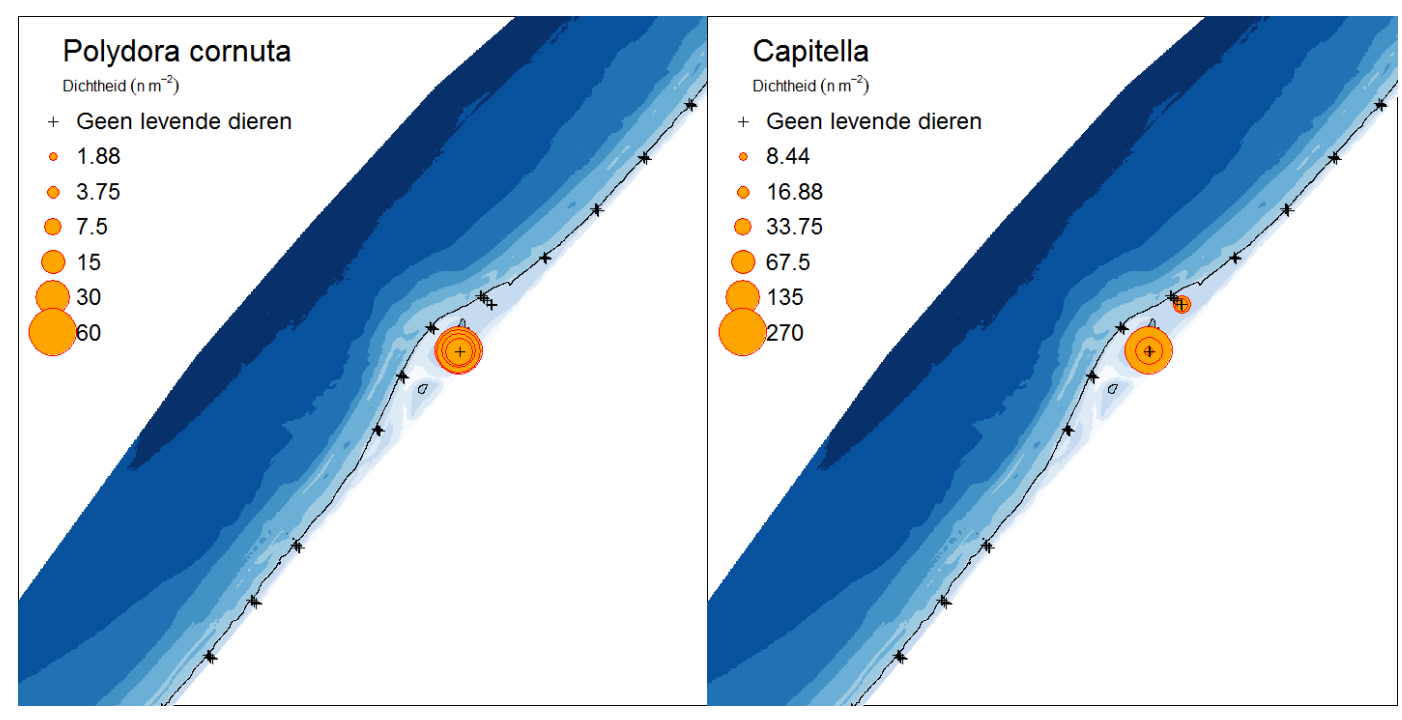

Figuur 58: Ruimtelijke verspreiding van de soorten Polydora cornuta (links) en Capitella spp.(rechts) in de strandmonsters. 


\section{$4 \quad$ Conclusies en discussie}

Het doel van de bodemdierbemonstering binnen het project "monitoring en evaluatie pilot Zandmotor" is te onderzoeken wat het effect is van de aanleg van de Zandmotor op de ontwikkeling van de bodemdiergemeenschap. Een megasuppletie zoals de Zandmotor verschilt van reguliere strand- en vooroeversuppleties door zijn langere levensduur (ca 20 jaar in vergelijking tot de 3-5 jaar voor reguliere suppleties) en de schaal, waardoor een Zandmotor een groter effect heeft op de fysica en morfologie in het gebied op en rond de suppletie. Omdat de bodemdiergemeenschap in belangrijke mate afhankelijk is van de abiotiek (sedimentsamenstelling, getijstroming, golven) zal mogelijk ook de bodemdiergemeenschap zich aanpassen aan de verander(en)de situatie. Dit onderzoek richt zich op de temporele en ruimtelijke ontwikkeling van de bodemdiergemeenschap op en rond de Zandmotor om zo de invloed van de Zandmotor te onderzoeken.

In het najaar van 2017 is er door Wageningen Marine Research voor de $5^{\mathrm{e}}$ keer, na de bemonsteringen van 2010, 2012, 2013 en 2015, een bodemdierbemonstering uitgevoerd op en rond de Zandmotor. In totaal zijn er 120 stations bemonsterd in de vooroever met de bodemschaaf en de Van Veen happer. Tevens zijn er 70 stations bemonsterd op het strand tussen de hoog- en laagwaterlijn. Aanvullend zijn er 330 sedimentmonsters genomen, deels op de stations waar ook bodemdieren zijn bemonsterd (190 stations), en deels op tussenliggende transecten (140 stations).

Er is zijn duidelijke ruimtelijke patronen in de sedimentsamenstelling (mediane korrelgrootte) in het onderzoeksgebied op en rond de Zandmotor. Deels zijn deze patronen het directe gevolg van de Zandmotor. Zo is het sediment in de vooroever aan de kop van de Zandmotor relatief grof en zijn er gebieden met relatief fijn sediment ontstaan net ten noorden en ten zuiden van de Zandmotor. Het relatief grove zand aan de kop van de Zandmotor is waarschijnlijk het gevolg van de grote dynamiek (getijstroming en golven). Het fijnere materiaal net ten noorden en ten zuiden is mogelijk het gevolg van het bezinken van fijner materiaal in deze wat luwere zones (Huisman et al., 2016).

De gemiddelde biomassa aan de bodemdieren in de bodemschaaf in 2017 (194 $\mathrm{gram} \mathrm{m}^{-2}$ ) is hoger dan in de jaren 2010, 2012 en 2015 (respectievelijk 57, 91 en $161 \mathrm{gram} \mathrm{m}^{-2}$ ), maar lager dan in 2013 (430 gram $\mathrm{m}^{-2}$ ), als gevolg van een hoge biomassa Ensis spp. in dat jaar. Het gemiddeld aantal taxa per monster (6.8 taxa per monster) is vergelijkbaar met voorgaande jaren (tussen de 5 en 7 taxa per monster, maar hoger dan in 2010, voor de aanleg van de Zandmotor (2.7 taxa per monster). In het najaar van 2017 zijn er relatief veel zaagjes (Donax vittatus), halfgeknotte strandschelpen (Spisula subtruncata), nonnetjes (Limecola balthica) en Nephtys cirrosa aangetroffen in de monsters van de bodemschaaf en de Van Veen happer. Wat betreft de halfgeknotte strandschelpen en zaagjes is dit overeenkomstig de patronen die zijn aangetroffen in de WOT bestandsopname in de kustzone (Troost et al., 2017). Het bestand aan Ensis spp. dat in 2017 is aangetroffen rond de Zandmotor is minder groot dan voorgaande jaren, terwijl het totaal bestand aan Ensis spp. in de Nederlandse kustzone in aantallen het hoogst is dat ooit is gemeten sinds 1995 (Troost et al., 2017). Het totale bestand aan bodemdieren (dichtheid, biomassa en aantal soorten) neemt toe met de waterdiepte. Vooral de ondiepe zone (tot en met -5 meter NAP) is arm en is gekenmerkt door specifieke soorten zoals de breedpootkrab (Portumnus latipes) en de gemshorenworm (Scolelepis (Scolelepis) squamata). Op grotere diepten (dieper dan -6 m NAP) neemt de dichtheid, biomassa en het aantal soorten per monster sterk toe, met de hoogste waarden op dieptes groter dan $11 \mathrm{~m}$.

De nMDS plots van zowel de bodemschaaf als van de Van Veen monsters laten, naast een dieptepatroon ook een sterk van jaar tot jaar effect zien. Na de aanleg in 2011 is de bodemdiergemeenschap sterk veranderd, zowel binnen het suppletiegebied als ten noorden en ten zuiden van de suppletie. Vanaf die tijd heeft het gebied zich verder ontwikkeld maar is niet teruggekeerd naar de situatie van voor de aanleg (2010). De Van Veen bemonstering laat wel een afwijking zien van de bodemdiergemeenschap in het suppletiegebied (transecten 5 tot en met 12) voor de jaren 2013 en 2017 ten opzichte van de gebieden noord en zuid van de suppletie. Dit is niet 
duidelijk te zien in de nMDS plot van de bodemschaaf. In de Van Veen bemonstering worden soorten bemonsterd zoals borstelwormen en kleine crustaceeën die niet met de bodemschaaf worden bemonsterd.

De resultaten van de bodemschaaf en de Van Veen bemonstering zijn tot op zekere hoogte goed met elkaar te vergelijken. Dit terwijl beide methodieken een ander type bodemdieren wordt bemonsterd. De bodemschaaf heeft een grotere maaswijdte $(5 \mathrm{~mm})$ zodat wormen en kleinere kreeftachtigen niet worden meegenomen. De bodemschaaf is dan ook vooral een geschikt monstertuig voor schelpdieren. Omdat deze schelpdieren een belangrijke bron zijn voor vogels, zijn in dit rapport dan ook voornamelijk verspreidingskaartjes van de biomassa uit de bodemschaaf opgenomen. Met de Van Veen happer worden juist de zeldzame grotere en mobiele dieren minder goed bemonsterd (Ens et al., 2007). Met de bodemschaaf wordt een groter bodemoppervlak bemonsterd dan met de Van Veen happer en is daarom minder gevoelig voor toevalligheden. De Van Veen happer is een geschikter monstertuig om iets te kunnen zeggen over de biodiversiteit. De verspreidingskaartjes van bodemdieren uit de Van Veen happer in dit rapport zijn daarom voornamelijk gebaseerd op de dichtheden.

De bodemdiergemeenschap van het strand, tussen de hoog- en laagwaterlijn, is aanzienlijk armer (vooral hoog in het intergetijdengebied) dan de bodemgemeenschap in de vooroever en wordt voornamelijk gekenmerkt door soorten als de Scolelepis (Scolelepis) squamata en Haustorius arenarius. Vooral de soortensamenstelling op het relatief beschutte strand langs de lagune wijkt af van de overige stations op het strand. Deze stations kenmerken zich bijvoorbeeld door de aanwezigheid van soorten als de borstelwormen Polydora cornuta en Capitella spp.

De aanleg van de Zandmotor heeft geleid tot meer diversiteit in abiotiek (bodemschuifspanning door getij en golven, sedimentsamenstelling, sedimentatie/erosie) in het onderzoeksgebied. De bodemdiergemeenschap lijkt zich hierop te hebben aangepast. Om het effect van de Zandmotor op de bodemdiergemeenschap goed te kunnen begrijpen, is het van belang de relatie met de abiotiek te analyseren en te begrijpen. Het zou daarom interessant zijn om de ruimtelijke en temporele patronen in de bodemdiergemeenschap te vergelijken met abiotische parameters die worden beïnvloedt door de Zandmotor zoals sedimentsamenstelling, golfenergie getijdenstroming en sedimentatie/erosie. Om dit te kunnen doen zullen resultaten van modelberekeningen (bodemschuifspanning golven en stroming), bathymetrieopnames (sedimentatie/erosie) en sedimentsamenstelling moeten worden vergleken met de resultaten van de bodemdierbemonstering. Deze kennis kan nuttig zijn in het ontwerp van toekomstige mega-suppleties zoals de Zandmotor.

De laatste bemonstering van bodemdieren zal worden uitgevoerd in het najaar van 2019. Het is de verwachting dat de bodemdiergemeenschap zich dan nog niet heeft herstelt naar de situatie van voor de aanleg (2010). Dit zou nog jaren kunnen duren, aangezien de verwachting is dat de Zandmotor pas na 20 jaar zal zijn verdwenen. Tot die tijd zal de Zandmotor de hydro- en morfodynamiek in het gebied en daarmee de bodemdiersamenstelling blijven beïnvloeden. 


\section{$5 \quad$ Kwaliteitsborging}

Wageningen Marine Research beschikt over een ISO 9001:2008 gecertificeerd kwaliteitsmanagementsysteem (certificaatnummer: 187378-2015-AQ-NLD-RvA). Dit certificaat is geldig tot 15 december 2018. De organisatie is gecertificeerd sinds 27 februari 2001. De certificering is uitgevoerd door DNV Certification B.V.

Het chemisch laboratorium te IJmuiden beschikt over een NEN-EN-ISO/IEC 17025:2005 accreditatie voor testlaboratoria met nummer L097. Deze accreditatie is geldig tot 1 april 2021 en is voor het eerst verleend op 27 maart 1997; deze accreditatie is verleend door de Raad voor Accreditatie. Het chemisch laboratorium heeft hierdoor aangetoond in staat te zijn op technisch bekwame wijze valide resultaten te leveren en te werken volgens de ISO17025 norm. De scope (L097) met de geaccrediteerde analysemethoden is te vinden op de website van de Raad voor Accreditatie (www.rva.nl).

Op grond van deze accreditatie is het kwaliteitskenmerk $Q$ toegekend aan de resultaten van die componenten die op de scope staan vermeld, mits aan alle kwaliteitseisen is voldaan. Het kwaliteitskenmerk Q staat vermeld in de tabellen met de onderzoeksresultaten. Indien het kwaliteitskenmerk $Q$ niet staat vermeld is de reden hiervan vermeld.

De kwaliteit van de analysemethoden wordt op verschillende manieren gewaarborgd. De juistheid van de analysemethoden wordt regelmatig getoetst door deelname aan ringonderzoeken waaronder die georganiseerd door QUASIMEME. Indien geen ringonderzoek voorhanden is, wordt een tweede lijnscontrole uitgevoerd. Tevens wordt bij iedere meetserie een eerstelijnscontrole uitgevoerd. Naast de lijnscontroles wordende volgende algemene kwaliteitscontroles uitgevoerd:

- Blanco onderzoek.

- Terugvinding (recovery).

- $\quad$ Interne standaard voor borging opwerkmethode.

- Injectie standard.

- Gevoeligheid.

Bovenstaande controles staan beschreven in Wageningen Marine Research werkvoorschrift ISW 2.10.2.105.

Indien gewenst kunnen gegevens met betrekking tot de prestatiekenmerken van de analysemethoden bij het chemisch laboratorium worden opgevraagd.

Indien sprake is van onbeheerste kwaliteit worden passende maatregelen genomen. 


\section{Literatuur}

Baptist, M., J. E. Tamis, B. W. Borsje en J. J. Van der Werf (2009) Review of the geomorphological, benthic ecological and biogeomorphological effects of nourishments on the shoreface and surf zone of the Dutch coast. Wageningen IMARES / Deltares, Rapport nummer: Report IMARES C113/08, Deltares Z4582.50.

Birklund, J. en J. W. M. Wijsman (2005) Ecological effects of aggregate extraction, Pages J1-J11 in L. C. Van Rijn, R. L. Soulsby, P. Hoekstra, en A. G. Davies, eds. Sandpit. Sand transport and morphology of offshore sand mining pits. Process knowledge and guidelines for coastal management. Amersfoort, Aqua Publications.

Boon, A. R. en J. W. M. Wijsman (2012) Monitoring en Evaluatie Pilot Zandmotor Fase 2 - Meetrapportage monstername najaar 2011 van benthos, vis vooroever, lagune en strand. Deltares / IMARES, Rapport nummer: C049/12, 28 pagina's.

Clarke, K. R., R. N. Gorley, P. J. Somerfield en R. M. Warwick (2014a) Change in marine communities: An approach to statistical analysis and interpretation. 3rd Edition. Plymouth, PRIMER-E Ltd.

Clarke, K. R., J. R. Tweedley en F. J. Valesini (2014b) Simple shade plots aid better long-term choices of data pre-treatment in multivariate assemblage studies. Journal of the Marine Biological Association of the United Kingdom 94: 1-16.

Clarke, K. R. en R. N. Gorley (2015) PRIMER v7: User manual/Tutorial. Plymouth, PRIMER-E Ltd.

Craeymeersch, J. A., D. Baars, E. Brummelhuis, T. P. Bult, J. J. Kesteloo en J. Perdon (2006) Handboek bestandsopnames en routinematige bemonstering van schelpdieren. Centrum Voor Visserijonderzoek (CVO), Rapport, 80 pagina's.

Ebbens, E. en J. Fiselier (2010) Monitoring- en evaluatieplan Zandmotor. DHV, Rapport, 38 pagina's

Ens, B. J., J. A. Craeymeersch, F. E. Fey, H. J. L. Heessen, A. C. Smaal, A. G. Brinkman, R. Dekker, J. R. Van Der Meer en M. Van Stralen (2007) Sublitorale natuurwaarden in de Waddenzee. Een overzicht van bestaande kennis en een beschrijving van de onderzoeksopzet voor een studie naar het effect van mosselzaadvisserij en mosselkweek op sublitorale natuurwaarden. Wageningen IMARES, Rapport nummer: C077/07, 117 pagina's.

Fiselier, J. (2010) Projectnota/ MER. Aanleg en zandwinning Zandmotor Delflandse kust. DHV, Rapport nummer: C6158-01.001, 303 pagina's.

Goldsmit, J., K. L. Howland en P. Archambault (2014) Establishing a baseline for early detection of nonindigenous species in ports of the Canadian Arctic. Aquatic Invasions 9: 327-342.

Huisman, B. J. A., M. A. De Schipper en B. G. Ruessink (2016) Sediment sorting at the Sand Motor at storm and annual time scales. Marine Geology 381: 209-226.

Taal, M., B. Arens, K. Kuijper, P. K. Tonnon, B. Van Der Valk, C. T. M. Vertegaal en J. W. M. Wijsman (2017) Uitvoeringsprogramma Monitoring en Evaluatie Pilot Zandmotor. Fase 3: periode 2017 t/m 2021. Deltares, Rapport nummer: 11200028-000-ZKS-0003, 68 pagina's.

Taal, M. D., M. A. M. Löffler, C. T. M. Vertegaal, J. W. M. Wijsman, B. Van Der Valk en P. K. Tonnon (2016a) Ontwikkeling van de Zandmotor. Samenvattende rapportage over de eerste vier jaar van het Monitoringen Evaluatie Programma (MEP). Deltares, Rapport, 61 pagina's.

Taal, M. D., M. A. M. Löffler, C. T. M. Vertegaal, J. W. M. Wijsman, B. Van Der Valk en P. K. Tonnon (2016b) Development of the Sand Motor Concise report describing the first four years of the Monitoring and Evaluation Programme (MEP). Deltares, Rapport, 61 pagina's.

Tonnon, P. K. en M. J. Baptist (2011) To-rapportage Monitoring en Evaluatie Pilot Zandmotor. Deltares/IMARES, Rapport nummer: Deltares 1203519-000 / IMARES C016/11, 198 pagina's.

Tonnon, P. K., L. Van der Valk, H. Holzhauer, M. J. Baptist, J. W. M. Wijsman, C. T. M. Vertegaal en S. M. Arens (2011) Uitvoeringsprogramma Monitoring en Evaluatie pilot Zandmotor. Deltares/Wageningen IMARES, Rapport nummer: C172/10, 154 pagina's.

Troost, K., K. J. Perdon, J. Van Zwol, J. Jol en M. Van Asch (2017) Schelpdierbestanden in de Nederlandse kustzone in 2017. Wageningen Marine Research, Rapport nummer: CVO Rapport 17.014, 39 pagina's.

Van der Wal, J. T. en J. A. Van Dalfsen (2008) Monitoring kustsuppleties. Wageningen IMARES, Rapport, 114 pagina's.

Van Egmond, E., M., P. M. Van Bodegom, M. P. Berg, J. W. M. Wijsman, L. Leewis, G. M. Janssen en R. Aerts (2018) A mega-nourishment creates novel habitat for intertidal macrointervebrates by enhancing habitat relief on the sandy beach. Estuarine Coastal And Shelf Science 207: 232-241.

Wentworth, C. K. (1922) A scale of grade and class terms for clastic sediments. Journal of Geology 30: 377392. 
Wijsman, J. W. M. en E. Verduin (2011) To monitoring Zandmotor Delflandse kust: Benthos ondiepe kustzone en natte strand. Wageningen IMARES, Rapport nummer: C039/11, 75 pagina's.

Wijsman, J. W. M. (2014a) Monitoring en Evaluatie Pilot zandmotor Fase 2: Datarapport benthos bemonstering vooroever en natte strand najaar 2012. Deltares / IMARES, Rapport nummer: C149/14, 49 pagina's.

Wijsman, J. W. M. (2014b) Monitoring en Evaluatie Pilot zandmotor Fase 2: Datarapport benthos bemonstering vooroever en natte strand najaar 2013. Deltares / IMARES, Rapport nummer: C150/14, 57 pagina's.

Wijsman, J. W. M., P. C. Goudswaard, V. Escaravage en S. Wijnhoven (2014) De macrobenthosgemeenschap van de Zeeuwse Banken na zandwinning. Een overzicht van drie $T_{0}$ jaren en een eerste jaar van rekolonisatie. IMARES, Rapport nummer: C164/13, 95 pagina's.

Wijsman, J. W. M. (2016) Monitoring en Evaluatie Pilot Zandmotor Fase 2 Datarapport benthos bemonstering vooroever en strand najaar 2015. IMARES, Rapport nummer: C006/16, 67 pagina's. 


\section{Verantwoording}

Rapport C073/18

Projectnummer: 4313100069

Dit rapport is met grote zorgvuldigheid tot stand gekomen. De wetenschappelijke kwaliteit is intern getoetst door een collega-onderzoeker en het verantwoordelijk lid van het managementteam van Wageningen Marine Research

Akkoord:

Dr. J.A. Craeymeersch

Akkoord:

Handtekening:

Datum:

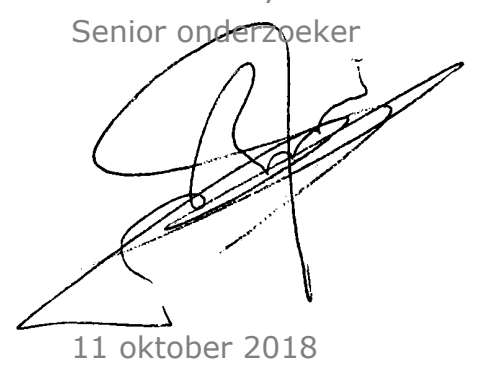

Akkoord:

Dr. T. Bult

Directeur Wageningen Marine Research

Handtekening:

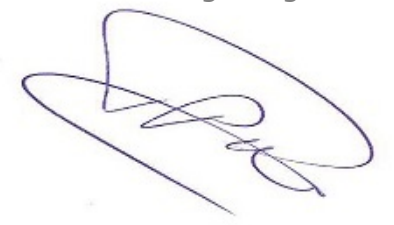

Datum:

11 oktober 2018 


\section{Bijlage 1 Bemonsteringslocaties Van Veen monsters}

\begin{tabular}{|c|c|c|c|c|c|c|}
\hline \multirow[t]{2}{*}{$\begin{array}{l}\text { Tabel 9: } \\
\text { Station Nr }\end{array}$} & \multicolumn{6}{|c|}{$\begin{array}{l}\text { Locaties bemonsterd met de Van Veen happer in } 2017 \text {. De cöordinaten } \\
\text { van de locaties zijn gegeven in decimale graden (WGS84). De } \\
\text { hoogteligging (cm t.o.v. NAP) is bepaald aan de hand van de ligging van } \\
\text { de locaties op de dieptekaart van juni } 2017 \text {. Op deze locaties zijn tevens } \\
\text { sedimentmonsters genomen. In de laatste kolom is aangegeven welk lab } \\
\text { het benthos heeft uitgezocht. }\end{array}$} \\
\hline & Datum & $\begin{array}{l}\text { Latitude } \\
\text { (WGS84) }\end{array}$ & $\begin{array}{l}\text { Longitude } \\
\text { (WGS84) }\end{array}$ & Transect & $\begin{array}{l}\text { Diepte } \\
\text { (cm NAP }\end{array}$ & Lab \\
\hline 2017_001 & $9-10-2017$ & 52.00800 & 4.131378 & 0 & -175 & WMR \\
\hline 2017_002 & $9-10-2017$ & 52.00825 & 4.1309 & 0 & -320 & Eurofins \\
\hline 2017_003 & $9-10-2017$ & 52.0085 & 4.130411 & 0 & -175 & WMR \\
\hline 2017_004 & $28-9-2017$ & 52.01018 & 4.127111 & 0 & -501 & Eurofins \\
\hline 2017_005 & $28-9-2017$ & 52.011 & 4.125512 & 0 & -695 & WMR \\
\hline 2017_006 & $28-9-2017$ & 52.01159 & 4.12435 & 0 & -793 & Eurofins \\
\hline 2017_007 & $28-9-2017$ & 52.01283 & 4.121933 & 0 & -900 & WMR \\
\hline 2017_008 & $28-9-2017$ & 52.01542 & 4.116844 & 0 & -1000 & Eurofins \\
\hline 2017_009 & $28-9-2017$ & 52.01845 & 4.11092 & 0 & -1098 & WMR \\
\hline 2017_010 & $28-9-2017$ & 52.02025 & 4.107396 & 0 & -1151 & Eurofins \\
\hline 2017_011 & $9-10-2017$ & 52.01492 & 4.140682 & 1 & -124 & WMR \\
\hline 2017_012 & $9-10-2017$ & 52.01533 & 4.139884 & 1 & -359 & Eurofins \\
\hline 2017_013 & $9-10-2017$ & 52.01558 & 4.139385 & 1 & -209 & WMR \\
\hline 2017_014 & $28-9-2017$ & 52.01685 & 4.136906 & 1 & -496 & Eurofins \\
\hline 2017_015 & $28-9-2017$ & 52.01789 & 4.134865 & 1 & -704 & WMR \\
\hline 2017_016 & $28-9-2017$ & 52.01842 & 4.13383 & 1 & -801 & Eurofins \\
\hline 2017_017 & $28-9-2017$ & 52.0192 & 4.132299 & 1 & -898 & WMR \\
\hline 2017_018 & $28-9-2017$ & 52.02104 & 4.128699 & 1 & -1001 & Eurofins \\
\hline 2017_019 & $28-9-2017$ & 52.02404 & 4.122817 & 1 & -1099 & WMR \\
\hline 2017_020 & $28-9-2017$ & 52.02575 & 4.119466 & 1 & -1151 & Eurofins \\
\hline 2017_021 & $9-10-2017$ & 52.02203 & 4.149606 & 2 & -158 & WMR \\
\hline 2017_022 & $29-9-2017$ & 52.02279 & 4.148125 & 2 & -476 & Eurofins \\
\hline 2017_023 & $29-9-2017$ & 52.02311 & 4.147499 & 2 & -280 & WMR \\
\hline 2017_024 & $29-9-2017$ & 52.02361 & 4.14652 & 2 & -494 & Eurofins \\
\hline 2017_025 & $29-9-2017$ & 52.02535 & 4.143096 & 2 & -702 & WMR \\
\hline 2017_026 & $29-9-2017$ & 52.02578 & 4.142253 & 2 & -806 & Eurofins \\
\hline 2017_027 & $29-9-2017$ & 52.02616 & 4.141525 & 2 & -889 & WMR \\
\hline 2017_028 & $29-9-2017$ & 52.02681 & 4.140237 & 2 & -998 & Eurofins \\
\hline 2017_029 & $29-9-2017$ & 52.02933 & 4.135314 & 2 & -1098 & WMR \\
\hline 2017_030 & $29-9-2017$ & 52.0314 & 4.131256 & 2 & -1150 & Eurofins \\
\hline 2017_031 & $9-10-2017$ & 52.02917 & 4.158468 & 3 & -153 & WMR \\
\hline 2017_032 & $9-10-2017$ & 52.02991 & 4.157015 & 3 & -370 & Eurofins \\
\hline 2017_033 & $29-9-2017$ & 52.03025 & 4.156364 & 3 & -266 & WMR \\
\hline 2017_034 & $29-9-2017$ & 52.03077 & 4.155329 & 3 & -502 & Eurofins \\
\hline 2017_035 & $29-9-2017$ & 52.03241 & 4.152119 & 3 & -705 & WMR \\
\hline 2017_036 & $29-9-2017$ & 52.0328 & 4.151357 & 3 & -804 & Eurofins \\
\hline 2017_037 & $29-9-2017$ & 52.03323 & 4.150524 & 3 & -889 & WMR \\
\hline 2017_038 & $29-9-2017$ & 52.03368 & 4.14964 & 3 & -992 & Eurofins \\
\hline 2017_039 & $29-9-2017$ & 52.03704 & 4.14307 & 3 & -1098 & WMR \\
\hline 2017_040 & $29-9-2017$ & 52.03875 & 4.139717 & 3 & -1151 & Eurofins \\
\hline
\end{tabular}




\begin{tabular}{|c|c|c|c|c|c|c|}
\hline StationNr & Datum & $\begin{array}{l}\text { Latitude } \\
\text { (WGS84) }\end{array}$ & $\begin{array}{l}\text { Longitude } \\
\text { (WGS84) }\end{array}$ & Transect & $\begin{array}{c}\text { Diepte } \\
\text { (cm NAP) }\end{array}$ & Lab \\
\hline 2017_041 & $9-10-2017$ & 52.04418 & 4.174784 & 5 & -152 & WMR \\
\hline 2017_042 & $29-9-2017$ & 52.04494 & 4.173298 & 5 & -450 & Eurofins \\
\hline 2017_043 & $29-9-2017$ & 52.04558 & 4.172039 & 5 & -333 & WMR \\
\hline 2017_044 & $29-9-2017$ & 52.04593 & 4.171358 & 5 & -498 & Eurofins \\
\hline 2017_045 & $29-9-2017$ & 52.04629 & 4.17064 & 5 & -700 & WMR \\
\hline 2017_046 & $29-9-2017$ & 52.04669 & 4.169872 & 5 & -797 & Eurofins \\
\hline 2017_047 & $29-9-2017$ & 52.04728 & 4.16872 & 5 & -900 & WMR \\
\hline 2017_048 & $29-9-2017$ & 52.04841 & 4.166506 & 5 & -1000 & Eurofins \\
\hline 2017_049 & $29-9-2017$ & 52.05113 & 4.161175 & 5 & -1100 & WMR \\
\hline 2017_050 & $29-9-2017$ & 52.0522 & 4.159072 & 5 & -1149 & Eurofins \\
\hline 2017_051 & $9-10-2017$ & 52.05079 & 4.180128 & 6 & -150 & WMR \\
\hline 2017_052 & $9-10-2017$ & 52.05147 & 4.178792 & 6 & -324 & Eurofins \\
\hline 2017_053 & $9-10-2017$ & 52.05204 & 4.177668 & 6 & -221 & WMR \\
\hline 2017_054 & $29-9-2017$ & 52.05271 & 4.176357 & 6 & -512 & Eurofins \\
\hline 2017_055 & $29-9-2017$ & 52.05352 & 4.174766 & 6 & -695 & WMR \\
\hline 2017_056 & $29-9-2017$ & 52.05407 & 4.173693 & 6 & -805 & Eurofins \\
\hline 2017_057 & $29-9-2017$ & 52.05468 & 4.172498 & 6 & -903 & WMR \\
\hline 2017_058 & $29-9-2017$ & 52.05508 & 4.171715 & 6 & -1005 & Eurofins \\
\hline 2017_059 & $29-9-2017$ & 52.05577 & 4.17036 & 6 & -1102 & WMR \\
\hline 2017_060 & $29-9-2017$ & 52.05647 & 4.169007 & 6 & -1146 & Eurofins \\
\hline 2017_061 & $9-10-2017$ & 52.05712 & 4.185998 & 7 & -152 & WMR \\
\hline 2017_062 & $9-10-2017$ & 52.05768 & 4.18492 & 7 & -227 & Eurofins \\
\hline 2017_063 & $9-10-2017$ & 52.05805 & 4.184186 & 7 & -182 & WMR \\
\hline 2017_064 & $29-9-2017$ & 52.05897 & 4.182384 & 7 & -503 & Eurofins \\
\hline 2017_065 & $29-9-2017$ & 52.05985 & 4.180672 & 7 & -707 & WMR \\
\hline 2017_066 & $29-9-2017$ & 52.06023 & 4.179925 & 7 & -802 & Eurofins \\
\hline 2017_067 & $29-9-2017$ & 52.06126 & 4.177909 & 7 & -900 & WMR \\
\hline 2017_068 & $29-9-2017$ & 52.06177 & 4.1769 & 7 & -1005 & Eurofins \\
\hline 2017_069 & $29-9-2017$ & 52.06223 & 4.176011 & 7 & -1097 & WMR \\
\hline 2017_070 & $29-9-2017$ & 52.06249 & 4.175491 & 7 & -1154 & Eurofins \\
\hline 2017_071 & $9-10-2017$ & 52.061 & 4.196696 & 8 & -169 & WMR \\
\hline 2017_072 & $9-10-2017$ & 52.06186 & 4.195018 & 8 & -394 & Eurofins \\
\hline 2017_073 & $29-9-2017$ & 52.06216 & 4.194413 & 8 & -301 & WMR \\
\hline 2017_074 & $29-9-2017$ & 52.06261 & 4.193544 & 8 & -505 & Eurofins \\
\hline 2017_075 & $29-9-2017$ & 52.06337 & 4.192044 & 8 & -704 & WMR \\
\hline 2017_076 & $29-9-2017$ & 52.0643 & 4.190224 & 8 & -798 & Eurofins \\
\hline 2017_077 & $29-9-2017$ & 52.06531 & 4.188262 & 8 & -908 & WMR \\
\hline 2017_078 & $29-9-2017$ & 52.06597 & 4.186963 & 8 & -997 & Eurofins \\
\hline 2017_079 & $29-9-2017$ & 52.06684 & 4.185258 & 8 & -1100 & WMR \\
\hline 2017_080 & 29-9-2017 & 52.06779 & 4.183397 & 8 & -1153 & Eurofins \\
\hline 2017_081 & $9-10-2017$ & 52.06651 & 4.208754 & 9 & -153 & WMR \\
\hline 2017_082 & $29-9-2017$ & 52.06759 & 4.206638 & 9 & -402 & Eurofins \\
\hline 2017_083 & $29-9-2017$ & 52.06787 & 4.206101 & 9 & -390 & WMR \\
\hline 2017_084 & $28-9-2017$ & 52.06834 & 4.205168 & 9 & -491 & Eurofins \\
\hline 2017_085 & $28-9-2017$ & 52.06893 & 4.204011 & 9 & -699 & WMR \\
\hline 2017_086 & $28-9-2017$ & 52.06936 & 4.203178 & 9 & -804 & Eurofins \\
\hline 2017_087 & $28-9-2017$ & 52.07007 & 4.201787 & 9 & -900 & WMR \\
\hline 2017_088 & $28-9-2017$ & 52.07153 & 4.198935 & 9 & -1000 & Eurofins \\
\hline 2017_089 & $28-9-2017$ & 52.07347 & 4.195137 & 9 & -1101 & WMR \\
\hline 2017_090 & $28-9-2017$ & 52.07472 & 4.192681 & 9 & -1150 & Eurofins \\
\hline 2017_091 & $9-10-2017$ & 52.07273 & 4.219438 & 10 & -174 & WMR \\
\hline 2017_092 & $9-10-2017$ & 52.07329 & 4.218329 & 10 & -458 & Eurofins \\
\hline 2017_093 & $29-9-2017$ & 52.07405 & 4.21684 & 10 & -337 & WMR \\
\hline
\end{tabular}




\begin{tabular}{|c|c|c|c|c|c|c|}
\hline StationNr & Datum & $\begin{array}{l}\text { Latitude } \\
\text { (WGS84) }\end{array}$ & $\begin{array}{l}\text { Longitude } \\
\text { (WGS84) }\end{array}$ & Transect & $\begin{array}{c}\text { Diepte } \\
\text { (cm NAP) }\end{array}$ & Lab \\
\hline 2017_094 & $28-9-2017$ & 52.07458 & 4.215817 & 10 & -508 & Eurofins \\
\hline 2017_095 & $28-9-2017$ & 52.07515 & 4.214688 & 10 & -706 & WMR \\
\hline 2017_096 & $28-9-2017$ & 52.07566 & 4.213699 & 10 & -798 & Eurofins \\
\hline 2017_097 & $28-9-2017$ & 52.07642 & 4.21221 & 10 & -897 & WMR \\
\hline 2017_098 & $28-9-2017$ & 52.07794 & 4.209245 & 10 & -999 & Eurofins \\
\hline 2017_099 & $28-9-2017$ & 52.08025 & 4.204719 & 10 & -1100 & WMR \\
\hline 2017_100 & $28-9-2017$ & 52.08176 & 4.201759 & 10 & -1149 & Eurofins \\
\hline 2017_101 & $9-10-2017$ & 52.07948 & 4.229072 & 11 & -151 & WMR \\
\hline 2017_102 & $9-10-2017$ & 52.07996 & 4.228141 & 11 & -432 & Eurofins \\
\hline 2017_103 & $9-10-2017$ & 52.08042 & 4.22724 & 11 & -277 & WMR \\
\hline 2017_104 & 29-9-2017 & 52.08113 & 4.225843 & 11 & -491 & Eurofins \\
\hline 2017_105 & $29-9-2017$ & 52.08177 & 4.2246 & 11 & -735 & WMR \\
\hline 2017_106 & $29-9-2017$ & 52.08227 & 4.223622 & 11 & -799 & Eurofins \\
\hline 2017_107 & $29-9-2017$ & 52.08305 & 4.222097 & 11 & -893 & WMR \\
\hline 2017_108 & $29-9-2017$ & 52.08516 & 4.217961 & 11 & -999 & Eurofins \\
\hline 2017_109 & $28-9-2017$ & 52.08756 & 4.213261 & 11 & -1099 & WMR \\
\hline 2017_110 & $28-9-2017$ & 52.08896 & 4.21053 & 11 & -1152 & Eurofins \\
\hline 2017_111 & $9-10-2017$ & 52.08634 & 4.238499 & 12 & -135 & WMR \\
\hline 2017_112 & $9-10-2017$ & 52.08715 & 4.236909 & 12 & -495 & Eurofins \\
\hline 2017_113 & $29-9-2017$ & 52.08752 & 4.236195 & 12 & -292 & WMR \\
\hline 2017_114 & $29-9-2017$ & 52.08806 & 4.23513 & 12 & -481 & Eurofins \\
\hline 2017_115 & $29-9-2017$ & 52.08857 & 4.234133 & 12 & -692 & WMR \\
\hline 2017_116 & $29-9-2017$ & 52.0893 & 4.232702 & 12 & -805 & Eurofins \\
\hline 2017_117 & 29-9-2017 & 52.09051 & 4.230343 & 12 & -902 & WMR \\
\hline 2017_118 & $28-9-2017$ & 52.09265 & 4.226162 & 12 & -997 & Eurofins \\
\hline 2017_119 & $28-9-2017$ & 52.09369 & 4.224115 & 12 & -1099 & WMR \\
\hline 2017_120 & $28-9-2017$ & 52.09461 & 4.222316 & 12 & -1152 & Eurofins \\
\hline
\end{tabular}




\section{Bijlage 2 Bemonsteringslocaties strand}

Tabel 10: Bemonsteringslocaties op het strand in 2017. De cöordinaten van de locaties zijn gegeven in decimale graden (WGS84). Op deze locaties zijn tevens de sedimentmonsters genomen. In de laatste kolom is aangegeven welk lab, Wageningen Marine Research (WMR) of Eurofins AquaSense / Bureau Waardenburg (Eurofins) het benthos heeft uitgezocht.

\begin{tabular}{|c|c|c|c|c|c|}
\hline Station Nr & Datum & Latitude & Longitude & Transect & Lab \\
\hline 2017_121 & $12-10-2017$ & 52.0075 & 4.132367 & 0 & WMR \\
\hline 2017_122 & $12-10-2017$ & 52.00744 & 4.132486 & 0 & Eurofins \\
\hline 2017_123 & $12-10-2017$ & 52.00721 & 4.132942 & 0 & WMR \\
\hline 2017_124 & $12-10-2017$ & 52.00706 & 4.133233 & 0 & Eurofins \\
\hline 2017_125 & $12-10-2017$ & 52.007 & 4.133344 & 0 & WMR \\
\hline 2017_126 & $12-10-2017$ & 52.0144 & 4.141705 & 1 & Eurofins \\
\hline 2017_127 & $12-10-2017$ & 52.01435 & 4.1418 & 1 & WMR \\
\hline 2017_128 & $12-10-2017$ & 52.01418 & 4.142134 & 1 & Eurofins \\
\hline 2017_129 & $12-10-2017$ & 52.01406 & 4.142369 & 1 & WMR \\
\hline 2017_130 & $12-10-2017$ & 52.01389 & 4.142692 & 1 & Eurofins \\
\hline 2017_131 & $12-10-2017$ & 52.02157 & 4.1505 & 2 & WMR \\
\hline 2017_132 & $12-10-2017$ & 52.02149 & 4.150669 & 2 & Eurofins \\
\hline 2017_133 & $12-10-2017$ & 52.02125 & 4.151129 & 2 & WMR \\
\hline 2017_134 & $12-10-2017$ & 52.02111 & 4.151414 & 2 & Eurofins \\
\hline 2017_135 & $12-10-2017$ & 52.02102 & 4.151579 & 2 & WMR \\
\hline 2017_136 & $12-10-2017$ & 52.02864 & 4.159501 & 3 & Eurofins \\
\hline 2017_137 & $12-10-2017$ & 52.02861 & 4.159565 & 3 & WMR \\
\hline 2017_138 & $12-10-2017$ & 52.02853 & 4.159732 & 3 & Eurofins \\
\hline 2017_139 & $12-10-2017$ & 52.02832 & 4.160127 & 3 & WMR \\
\hline 2017_140 & $12-10-2017$ & 52.02826 & 4.160256 & 3 & Eurofins \\
\hline 2017_141 & $12-10-2017$ & 52.04359 & 4.175933 & 5 & WMR \\
\hline 2017_142 & $12-10-2017$ & 52.04353 & 4.176049 & 5 & Eurofins \\
\hline 2017_143 & $12-10-2017$ & 52.04348 & 4.176142 & 5 & WMR \\
\hline 2017_144 & $12-10-2017$ & 52.04341 & 4.176285 & 5 & Eurofins \\
\hline 2017_145 & $12-10-2017$ & 52.04336 & 4.176391 & 5 & WMR \\
\hline 2017_146 & $12-10-2017$ & 52.05053 & 4.18063 & 6 & Eurofins \\
\hline 2017_147 & $12-10-2017$ & 52.05046 & 4.180765 & 6 & WMR \\
\hline 2017_148 & $12-10-2017$ & 52.05028 & 4.181114 & 6 & Eurofins \\
\hline 2017_149 & $12-10-2017$ & 52.05021 & 4.181263 & 6 & WMR \\
\hline 2017_150 & $12-10-2017$ & 52.05016 & 4.181348 & 6 & Eurofins \\
\hline 2017_151 & $12-10-2017$ & 52.05683 & 4.186565 & 7 & WMR \\
\hline 2017_152 & $12-10-2017$ & 52.05674 & 4.186757 & 7 & Eurofins \\
\hline 2017_153 & $12-10-2017$ & 52.05654 & 4.187136 & 7 & WMR \\
\hline 2017_154 & $12-10-2017$ & 52.05647 & 4.187286 & 7 & Eurofins \\
\hline 2017_155 & $12-10-2017$ & 52.0564 & 4.187408 & 7 & WMR \\
\hline 2017_156 & $11-10-2017$ & 52.06088 & 4.196918 & 8 & Eurofins \\
\hline 2017_157 & $11-10-2017$ & 52.06083 & 4.197019 & 8 & WMR \\
\hline 2017_158 & $11-10-2017$ & 52.06067 & 4.197336 & 8 & Eurofins \\
\hline 2017_159 & $11-10-2017$ & 52.06049 & 4.197698 & 8 & WMR \\
\hline 2017_160 & $11-10-2017$ & 52.06021 & 4.198236 & 8 & Eurofins \\
\hline 2017_161 & $11-10-2017$ & 52.0659 & 4.209943 & 9 & WMR \\
\hline 2017_162 & $11-10-2017$ & 52.06589 & 4.209972 & 9 & Eurofins \\
\hline 2017_163 & $11-10-2017$ & 52.06584 & 4.210058 & 9 & WMR \\
\hline
\end{tabular}




\begin{tabular}{|c|c|c|c|c|c|}
\hline StationNr & Datum & Latitude & Longitude & Transect & Lab \\
\hline 2017_164 & $11-10-2017$ & 52.06577 & 4.210202 & 9 & Eurofins \\
\hline 2017_165 & $11-10-2017$ & 52.06571 & 4.210311 & 9 & WMR \\
\hline 2017_166 & $11-10-2017$ & 52.07225 & 4.220377 & 10 & Eurofins \\
\hline 2017_167 & $11-10-2017$ & 52.07223 & 4.220407 & 10 & WMR \\
\hline 2017_168 & $11-10-2017$ & 52.07217 & 4.22052 & 10 & Eurofins \\
\hline 2017_169 & $11-10-2017$ & 52.07203 & 4.220809 & 10 & WMR \\
\hline 2017_170 & $11-10-2017$ & 52.07191 & 4.22104 & 10 & Eurofins \\
\hline 2017_171 & $11-10-2017$ & 52.07896 & 4.230084 & 11 & WMR \\
\hline 2017_172 & $11-10-2017$ & 52.07894 & 4.23013 & 11 & Eurofins \\
\hline 2017_173 & $11-10-2017$ & 52.0789 & 4.230212 & 11 & WMR \\
\hline 2017_174 & $11-10-2017$ & 52.07878 & 4.230448 & 11 & Eurofins \\
\hline 2017_175 & $11-10-2017$ & 52.07864 & 4.230716 & 11 & WMR \\
\hline 2017_176 & $11-10-2017$ & 52.08585 & 4.239455 & 12 & Eurofins \\
\hline 2017_177 & $11-10-2017$ & 52.08583 & 4.239486 & 12 & WMR \\
\hline 2017_178 & $11-10-2017$ & 52.08569 & 4.23977 & 12 & Eurofins \\
\hline 2017_179 & $11-10-2017$ & 52.08563 & 4.239883 & 12 & WMR \\
\hline 2017_180 & $11-10-2017$ & 52.08553 & 4.240076 & 12 & Eurofins \\
\hline 2017_196 & $11-10-2017$ & 52.05972 & 4.1992 & 8 & Eurofins \\
\hline 2017_197 & $11-10-2017$ & 52.05973 & 4.199185 & 8 & WMR \\
\hline 2017_198 & $11-10-2017$ & 52.05974 & 4.199161 & 8 & Eurofins \\
\hline 2017_199 & $11-10-2017$ & 52.05975 & 4.199138 & 8 & WMR \\
\hline 2017_200 & $11-10-2017$ & 52.05976 & 4.19912 & 8 & Eurofins \\
\hline 2017_201 & $11-10-2017$ & 52.05378 & 4.192539 & 7 & WMR \\
\hline 2017_202 & $11-10-2017$ & 52.05376 & 4.192586 & 7 & Eurofins \\
\hline 2017_203 & $11-10-2017$ & 52.05373 & 4.192641 & 7 & WMR \\
\hline 2017_204 & $11-10-2017$ & 52.0537 & 4.192698 & 7 & Eurofins \\
\hline 2017_205 & $11-10-2017$ & 52.05365 & 4.192807 & 7 & WMR \\
\hline
\end{tabular}




\section{Bijlage 3 Bemonsteringslocaties bodemschaaf}

\begin{tabular}{|c|c|c|c|c|c|}
\hline Tabel 11: & $\begin{array}{l}\text { Bemonster } \\
\text { de vooraf } \\
\text { diepte is } \mathrm{g}\end{array}$ & $\begin{array}{l}\text { locaties } \\
\text { ialde loc } \\
\text { seerd op }\end{array}$ & $\begin{array}{l}\text { de bode } \\
\text { zijn geg } \\
\text { dieptekaa }\end{array}$ & $\begin{array}{l}\text { haaf in } \\
n \text { in deci } \\
\text { an juni }\end{array}$ & $\begin{array}{l}\text { De cöordi } \\
\text { graden(W }\end{array}$ \\
\hline StationNr & Datum & $\begin{array}{l}\text { Latitude } \\
\text { (WGS84) }\end{array}$ & $\begin{array}{l}\text { Longitude } \\
\text { (WGS84) }\end{array}$ & Transect & $\begin{array}{l}\text { Diepte } \\
\text { (cm NAP) }\end{array}$ \\
\hline 2017_003 & $27-9-2017$ & 52.0085 & 4.130411 & 0 & -175 \\
\hline 2017_004 & $27-9-2017$ & 52.01018 & 4.127111 & 0 & -501 \\
\hline 2017_005 & $28-9-2017$ & 52.011 & 4.125512 & 0 & -695 \\
\hline 2017_006 & $28-9-2017$ & 52.01159 & 4.12435 & 0 & -793 \\
\hline 2017_007 & $28-9-2017$ & 52.01283 & 4.121933 & 0 & -900 \\
\hline 2017_008 & $25-9-2017$ & 52.01542 & 4.116844 & 0 & -1000 \\
\hline 2017_009 & $25-9-2017$ & 52.01845 & 4.11092 & 0 & -1098 \\
\hline 2017_010 & $25-9-2017$ & 52.02025 & 4.107396 & 0 & -1151 \\
\hline 2017_012 & $27-9-2017$ & 52.01533 & 4.139884 & 1 & -359 \\
\hline 2017_013 & $27-9-2017$ & 52.01558 & 4.139385 & 1 & -209 \\
\hline 2017_014 & $27-9-2017$ & 52.01685 & 4.136906 & 1 & -496 \\
\hline 2017_015 & $28-9-2017$ & 52.01789 & 4.134865 & 1 & -704 \\
\hline 2017_016 & $28-9-2017$ & 52.01842 & 4.13383 & 1 & -801 \\
\hline 2017_017 & $27-9-2017$ & 52.0192 & 4.132299 & 1 & -898 \\
\hline 2017_018 & $27-9-2017$ & 52.02104 & 4.128699 & 1 & -1001 \\
\hline 2017_019 & $25-9-2017$ & 52.02404 & 4.122817 & 1 & -1099 \\
\hline 2017_020 & $25-9-2017$ & 52.02575 & 4.119466 & 1 & -1151 \\
\hline 2017_022 & $27-9-2017$ & 52.02279 & 4.148125 & 2 & -476 \\
\hline 2017_023 & $27-9-2017$ & 52.02311 & 4.147499 & 2 & -280 \\
\hline 2017_024 & $27-9-2017$ & 52.02361 & 4.14652 & 2 & -494 \\
\hline 2017_025 & $28-9-2017$ & 52.02535 & 4.143096 & 2 & -702 \\
\hline 2017_026 & $28-9-2017$ & 52.02578 & 4.142253 & 2 & -806 \\
\hline 2017_027 & $28-9-2017$ & 52.02616 & 4.141525 & 2 & -889 \\
\hline 2017_028 & $27-9-2017$ & 52.02681 & 4.140237 & 2 & -998 \\
\hline 2017_029 & $25-9-2017$ & 52.02933 & 4.135314 & 2 & -1098 \\
\hline 2017_030 & $25-9-2017$ & 52.0314 & 4.131256 & 2 & -1150 \\
\hline 2017_032 & $27-9-2017$ & 52.02991 & 4.157015 & 3 & -370 \\
\hline 2017_033 & $27-9-2017$ & 52.03025 & 4.156364 & 3 & -266 \\
\hline 2017_034 & $27-9-2017$ & 52.03077 & 4.155329 & 3 & -502 \\
\hline 2017_035 & $28-9-2017$ & 52.03241 & 4.152119 & 3 & -705 \\
\hline 2017_036 & $28-9-2017$ & 52.0328 & 4.151357 & 3 & -804 \\
\hline 2017_037 & $28-9-2017$ & 52.03323 & 4.150524 & 3 & -889 \\
\hline 2017_038 & $27-9-2017$ & 52.03368 & 4.14964 & 3 & -992 \\
\hline 2017_039 & $25-9-2017$ & 52.03704 & 4.14307 & 3 & -1098 \\
\hline 2017_040 & $25-9-2017$ & 52.03875 & 4.139717 & 3 & -1151 \\
\hline 2017_042 & $27-9-2017$ & 52.04494 & 4.173298 & 5 & -450 \\
\hline 2017_043 & $27-9-2017$ & 52.04558 & 4.172039 & 5 & -333 \\
\hline 2017_044 & $28-9-2017$ & 52.04593 & 4.171358 & 5 & -498 \\
\hline 2017_045 & $25-9-2017$ & 52.04629 & 4.17064 & 5 & -700 \\
\hline 2017_046 & $28-9-2017$ & 52.04669 & 4.169872 & 5 & -797 \\
\hline 2017_047 & $28-9-2017$ & 52.04728 & 4.16872 & 5 & -900 \\
\hline 2017_048 & $27-9-2017$ & 52.04841 & 4.166506 & 5 & -1000 \\
\hline 2017_049 & $25-9-2017$ & 52.05113 & 4.161175 & 5 & -1100 \\
\hline
\end{tabular}




\begin{tabular}{|c|c|c|c|c|c|}
\hline StationNr & Datum & $\begin{array}{l}\text { Latitude } \\
\text { (WGS84) }\end{array}$ & $\begin{array}{l}\text { Longitude } \\
\text { (WGS84) }\end{array}$ & Transect & $\begin{array}{c}\text { Diepte } \\
\text { (cm NAP) }\end{array}$ \\
\hline 2017_050 & $25-9-2017$ & 52.0522 & 4.159072 & 5 & -1149 \\
\hline 2017_052 & $27-9-2017$ & 52.05147 & 4.178792 & 6 & -324 \\
\hline 2017_053 & $27-9-2017$ & 52.05204 & 4.177668 & 6 & -221 \\
\hline 2017_054 & $27-9-2017$ & 52.05271 & 4.176357 & 6 & -512 \\
\hline 2017_055 & $28-9-2017$ & 52.05352 & 4.174766 & 6 & -695 \\
\hline 2017_056 & $27-9-2017$ & 52.05407 & 4.173693 & 6 & -805 \\
\hline 2017_057 & $26-9-2017$ & 52.05468 & 4.172498 & 6 & -903 \\
\hline 2017_058 & $26-9-2017$ & 52.05508 & 4.171715 & 6 & -1005 \\
\hline 2017_059 & $25-9-2017$ & 52.05577 & 4.17036 & 6 & -1102 \\
\hline 2017_060 & $25-9-2017$ & 52.05647 & 4.169007 & 6 & -1146 \\
\hline 2017_062 & $27-9-2017$ & 52.05768 & 4.18492 & 7 & -227 \\
\hline 2017_063 & $27-9-2017$ & 52.05805 & 4.184186 & 7 & -182 \\
\hline 2017_064 & $27-9-2017$ & 52.05897 & 4.182384 & 7 & -503 \\
\hline 2017_065 & $28-9-2017$ & 52.05985 & 4.180672 & 7 & -707 \\
\hline 2017_066 & $27-9-2017$ & 52.06023 & 4.179925 & 7 & -802 \\
\hline 2017_067 & $26-9-2017$ & 52.06126 & 4.177909 & 7 & -900 \\
\hline 2017_068 & $26-9-2017$ & 52.06177 & 4.1769 & 7 & -1005 \\
\hline 2017_069 & $25-9-2017$ & 52.06223 & 4.176011 & 7 & -1097 \\
\hline 2017_070 & $25-9-2017$ & 52.06249 & 4.175491 & 7 & -1154 \\
\hline 2017_072 & $27-9-2017$ & 52.06186 & 4.195018 & 8 & -394 \\
\hline 2017_073 & $27-9-2017$ & 52.06216 & 4.194413 & 8 & -301 \\
\hline 2017_074 & $27-9-2017$ & 52.06261 & 4.193544 & 8 & -505 \\
\hline 2017_075 & $26-9-2017$ & 52.06337 & 4.192044 & 8 & -704 \\
\hline 2017_076 & $26-9-2017$ & 52.0643 & 4.190224 & 8 & -798 \\
\hline 2017_077 & $26-9-2017$ & 52.06531 & 4.188262 & 8 & -908 \\
\hline 2017_078 & $26-9-2017$ & 52.06597 & 4.186963 & 8 & -997 \\
\hline 2017_079 & $25-9-2017$ & 52.06684 & 4.185258 & 8 & -1100 \\
\hline 2017_080 & $25-9-2017$ & 52.06779 & 4.183397 & 8 & -1153 \\
\hline 2017_082 & $26-9-2017$ & 52.06759 & 4.206638 & 9 & -402 \\
\hline 2017_083 & $26-9-2017$ & 52.06787 & 4.206101 & 9 & -390 \\
\hline 2017_084 & $26-9-2017$ & 52.06834 & 4.205168 & 9 & -491 \\
\hline 2017_085 & $26-9-2017$ & 52.06893 & 4.204011 & 9 & -699 \\
\hline 2017_086 & $26-9-2017$ & 52.06936 & 4.203178 & 9 & -804 \\
\hline 2017_087 & $26-9-2017$ & 52.07007 & 4.201787 & 9 & -900 \\
\hline 2017_088 & $26-9-2017$ & 52.07153 & 4.198935 & 9 & -1000 \\
\hline 2017_089 & $25-9-2017$ & 52.07347 & 4.195137 & 9 & -1101 \\
\hline 2017_090 & $25-9-2017$ & 52.07472 & 4.192681 & 9 & -1150 \\
\hline 2017_092 & $26-9-2017$ & 52.07329 & 4.218329 & 10 & -458 \\
\hline 2017_093 & $26-9-2017$ & 52.07405 & 4.21684 & 10 & -337 \\
\hline 2017_094 & $26-9-2017$ & 52.07458 & 4.215817 & 10 & -508 \\
\hline 2017_095 & $26-9-2017$ & 52.07515 & 4.214688 & 10 & -706 \\
\hline 2017_096 & $26-9-2017$ & 52.07566 & 4.213699 & 10 & -798 \\
\hline 2017_097 & $26-9-2017$ & 52.07642 & 4.21221 & 10 & -897 \\
\hline 2017_098 & $26-9-2017$ & 52.07794 & 4.209245 & 10 & -999 \\
\hline 2017_099 & $25-9-2017$ & 52.08025 & 4.204719 & 10 & -1100 \\
\hline 2017_100 & $25-9-2017$ & 52.08176 & 4.201759 & 10 & -1149 \\
\hline 2017_102 & $26-9-2017$ & 52.07996 & 4.228141 & 11 & -432 \\
\hline 2017_103 & $26-9-2017$ & 52.08042 & 4.22724 & 11 & -277 \\
\hline 2017_104 & $26-9-2017$ & 52.08113 & 4.225843 & 11 & -491 \\
\hline 2017_105 & $26-9-2017$ & 52.08177 & 4.2246 & 11 & -735 \\
\hline 2017_106 & $26-9-2017$ & 52.08227 & 4.223622 & 11 & -799 \\
\hline 2017_107 & $26-9-2017$ & 52.08305 & 4.222097 & 11 & -893 \\
\hline $2017 \_108$ & $26-9-2017$ & 52.08516 & 4.217961 & 11 & -999 \\
\hline
\end{tabular}




\begin{tabular}{|c|c|c|c|c|c|}
\hline StationNr & Datum & $\begin{array}{l}\text { Latitude } \\
\text { (WGS84) }\end{array}$ & $\begin{array}{l}\text { Longitude } \\
\text { (WGS84) }\end{array}$ & Transect & $\begin{array}{l}\text { Diepte } \\
\text { (cm NAP) }\end{array}$ \\
\hline 2017_109 & $25-9-2017$ & 52.08756 & 4.213261 & 11 & -1099 \\
\hline 2017_110 & $25-9-2017$ & 52.08896 & 4.21053 & 11 & -1152 \\
\hline 2017_112 & $26-9-2017$ & 52.08715 & 4.236909 & 12 & -495 \\
\hline 2017_113 & $26-9-2017$ & 52.08752 & 4.236195 & 12 & -292 \\
\hline 2017_114 & $26-9-2017$ & 52.08806 & 4.23513 & 12 & -481 \\
\hline 2017_115 & $26-9-2017$ & 52.08857 & 4.234133 & 12 & -692 \\
\hline 2017_116 & $26-9-2017$ & 52.0893 & 4.232702 & 12 & -805 \\
\hline 2017_117 & $26-9-2017$ & 52.09051 & 4.230343 & 12 & -902 \\
\hline 2017_118 & $26-9-2017$ & 52.09265 & 4.226162 & 12 & -997 \\
\hline 2017_119 & $25-9-2017$ & 52.09369 & 4.224115 & 12 & -1099 \\
\hline 2017_120 & $25-9-2017$ & 52.09461 & 4.222316 & 12 & -1152 \\
\hline
\end{tabular}




\section{Bijlage 4 Sedimentsamenstelling}

Tabel 12: Overzicht resultaten sedimentsamenstelling 2017. Aangegeven zijn de parameters mediane korrelgrootte $(\mu \mathrm{m})$, percentage silt $(<63 \mu \mathrm{m})$, percentage zeer fijn zand (63-125 $\mu \mathrm{m})$, percentage fijn zand (125-250 $\mu \mathrm{m})$, percentage medium zand $(250-500 \mu \mathrm{m})$ en percentage grof zand (500-1000 $\mu \mathrm{m})$.

\begin{tabular}{|c|c|c|c|c|c|c|c|c|}
\hline StationNr & $\begin{array}{l}\text { Latitude } \\
\text { (WGS84) }\end{array}$ & $\begin{array}{l}\text { Longitude } \\
\text { (WGS84) }\end{array}$ & $\begin{array}{c}\text { Mediaan } \\
\text { ( } \mu \mathrm{m})\end{array}$ & Silt (\%) & $\begin{array}{l}\text { Zeer fijn } \\
\text { zand }(\%)\end{array}$ & $\begin{array}{c}\text { Fijn zand } \\
(\%)\end{array}$ & $\begin{array}{l}\text { Medium } \\
\text { zand }(\%)\end{array}$ & $\begin{array}{l}\text { Grof zand } \\
\qquad(\%)\end{array}$ \\
\hline 2017_001 & 52.00800 & 4.13138 & 358.5 & 0.00 & 0.20 & 21.76 & 53.67 & 24.37 \\
\hline 2017_002 & 52.00825 & 4.13090 & 260.4 & 0.00 & 0.56 & 44.59 & 52.95 & 1.91 \\
\hline 2017_003 & 52.00850 & 4.13041 & 280.4 & 0.00 & 0.14 & 36.32 & 60.20 & 3.34 \\
\hline 2017_004 & 52.01018 & 4.12711 & 189.2 & 23.25 & 9.85 & 32.95 & 29.84 & 4.18 \\
\hline 2017_005 & 52.01100 & 4.12551 & 142.7 & 20.57 & 21.54 & 42.25 & 15.45 & 0.27 \\
\hline 2017_006 & 52.01159 & 4.12435 & 157.0 & 0.24 & 28.98 & 56.56 & 12.90 & 1.35 \\
\hline 2017_007 & 52.01283 & 4.12193 & 165.9 & 7.46 & 24.14 & 43.42 & 19.56 & 5.50 \\
\hline 2017_008 & 52.01542 & 4.11684 & 162.3 & 6.77 & 25.05 & 46.13 & 17.96 & 4.17 \\
\hline 2017_009 & 52.01845 & 4.11092 & 166.1 & 0.10 & 24.68 & 58.80 & 16.43 & 0.01 \\
\hline 2017_010 & 52.02025 & 4.10740 & 157.9 & 4.78 & 25.28 & 56.05 & 13.92 & 0.00 \\
\hline 2017_011 & 52.01492 & 4.14068 & 254.5 & 0.00 & 0.71 & 47.17 & 50.45 & 1.67 \\
\hline 2017_012 & 52.01533 & 4.13988 & 246.6 & 0.00 & 0.60 & 51.21 & 47.66 & 0.53 \\
\hline 2017_013 & 52.01558 & 4.13939 & 241.0 & 0.00 & 1.17 & 53.31 & 44.92 & 0.59 \\
\hline 2017_014 & 52.01685 & 4.13691 & 188.0 & 22.76 & 8.23 & 37.62 & 29.60 & 1.83 \\
\hline 2017_015 & 52.01789 & 4.13487 & 181.3 & 9.94 & 13.54 & 52.09 & 23.89 & 0.54 \\
\hline 2017_016 & 52.01842 & 4.13383 & 175.5 & 0.01 & 20.77 & 58.71 & 20.34 & 0.17 \\
\hline 2017_017 & 52.01920 & 4.13230 & 170.9 & 12.43 & 17.79 & 45.29 & 23.10 & 1.43 \\
\hline 2017_018 & 52.02104 & 4.12870 & 222.1 & 3.94 & 11.66 & 42.55 & 34.11 & 7.74 \\
\hline 2017_019 & 52.02404 & 4.12282 & 215.6 & 1.55 & 14.01 & 44.39 & 30.33 & 9.72 \\
\hline 2017_020 & 52.02575 & 4.11947 & 193.8 & 12.76 & 13.26 & 40.02 & 28.50 & 5.49 \\
\hline 2017_021 & 52.02203 & 4.14961 & 311.5 & 0.00 & 0.67 & 30.64 & 53.51 & 15.18 \\
\hline 2017_022 & 52.02279 & 4.14813 & 272.6 & 5.20 & 0.28 & 35.17 & 55.84 & 3.52 \\
\hline 2017_023 & 52.02311 & 4.14750 & 254.4 & 0.00 & 0.80 & 47.14 & 50.36 & 1.70 \\
\hline 2017_024 & 52.02361 & 4.14652 & 214.3 & 4.22 & 2.34 & 62.37 & 31.04 & 0.03 \\
\hline 2017_025 & 52.02535 & 4.14310 & 303.1 & 0.00 & 1.41 & 31.86 & 54.84 & 11.89 \\
\hline 2017_026 & 52.02578 & 4.14225 & 286.7 & 9.56 & 5.11 & 27.28 & 40.42 & 17.64 \\
\hline 2017_027 & 52.02616 & 4.14153 & 228.5 & 3.42 & 8.05 & 45.45 & 36.57 & 6.50 \\
\hline 2017_028 & 52.02681 & 4.14024 & 219.3 & 12.84 & 13.73 & 29.07 & 26.05 & 18.37 \\
\hline 2017_029 & 52.02933 & 4.13531 & 540.4 & 0.39 & 1.50 & 3.13 & 38.30 & 56.71 \\
\hline 2017_030 & 52.03140 & 4.13126 & 229.2 & 10.05 & 10.56 & 34.78 & 35.70 & 8.95 \\
\hline 2017_031 & 52.02917 & 4.15847 & 283.3 & 0.00 & 0.16 & 35.46 & 60.24 & 4.14 \\
\hline 2017_032 & 52.02991 & 4.15702 & 252.5 & 0.00 & 0.82 & 47.98 & 49.83 & 1.37 \\
\hline 2017_033 & 52.03025 & 4.15636 & 280.4 & 0.00 & 0.46 & 37.38 & 57.06 & 5.11 \\
\hline 2017_034 & 52.03077 & 4.15533 & 252.2 & 0.00 & 1.83 & 47.23 & 48.58 & 2.35 \\
\hline 2017_035 & 52.03241 & 4.15212 & 324.0 & 0.00 & 0.24 & 26.17 & 60.06 & 13.52 \\
\hline 2017_036 & 52.03280 & 4.15136 & 312.1 & 0.00 & 0.59 & 29.36 & 57.83 & 12.22 \\
\hline 2017_037 & 52.03323 & 4.15052 & 219.7 & 0.00 & 7.53 & 54.53 & 36.35 & 1.59 \\
\hline 2017_038 & 52.03368 & 4.14964 & 207.2 & 0.01 & 14.60 & 49.17 & 28.32 & 7.90 \\
\hline 2017_039 & 52.03704 & 4.14307 & 279.6 & 0.00 & 1.83 & 37.89 & 52.30 & 7.98 \\
\hline 2017_040 & 52.03875 & 4.13972 & 446.8 & 1.79 & 2.72 & 13.31 & 40.15 & 42.04 \\
\hline 2017_041 & 52.04418 & 4.17478 & 258.8 & 0.00 & 2.09 & 44.48 & 48.79 & 4.64 \\
\hline 2017_042 & 52.04494 & 4.17330 & 448.7 & 0.00 & 0.00 & 6.49 & 54.22 & 39.28 \\
\hline
\end{tabular}




\begin{tabular}{|c|c|c|c|c|c|c|c|c|}
\hline StationNr & $\begin{array}{l}\text { Latitude } \\
\text { (WGS84) }\end{array}$ & $\begin{array}{l}\text { Longitude } \\
\text { (wGS84) }\end{array}$ & $\begin{array}{c}\text { Mediaan } \\
(\mu \mathrm{m})\end{array}$ & Silt $(\%)$ & $\begin{array}{c}\text { Zeer fijn } \\
\text { zand }(\%)\end{array}$ & $\begin{array}{c}\text { Fijn zand } \\
(\%)\end{array}$ & $\begin{array}{l}\text { Medium } \\
\text { zand ( } \%)\end{array}$ & $\begin{array}{c}\text { Grof zand } \\
(\%)\end{array}$ \\
\hline 2017_043 & 52.04558 & 4.17204 & 348.9 & 0.00 & 0.00 & 12.02 & 77.83 & 10.15 \\
\hline 2017_044 & 52.04593 & 4.17136 & 262.4 & 0.00 & 0.54 & 43.66 & 54.20 & 1.60 \\
\hline 2017_045 & 52.04629 & 4.17064 & 214.8 & 0.00 & 10.49 & 52.25 & 33.47 & 3.79 \\
\hline 2017_046 & 52.04669 & 4.16987 & 488.1 & 7.15 & 1.16 & 1.56 & 42.56 & 47.60 \\
\hline 2017_047 & 52.04728 & 4.16872 & 331.0 & 4.66 & 0.88 & 24.02 & 49.88 & 20.56 \\
\hline 2017_048 & 52.04841 & 4.16651 & 193.3 & 10.34 & 11.83 & 47.40 & 28.99 & 1.46 \\
\hline 2017_049 & 52.05113 & 4.16118 & 222.7 & 0.00 & 4.66 & 57.54 & 36.88 & 0.92 \\
\hline 2017_050 & 52.05220 & 4.15907 & 213.3 & 0.00 & 9.32 & 54.85 & 32.63 & 3.20 \\
\hline 2017_051 & 52.05079 & 4.18013 & 326.6 & 0.00 & 0.06 & 23.69 & 63.93 & 12.33 \\
\hline 2017_052 & 52.05147 & 4.17879 & 441.1 & 0.00 & 0.00 & 5.44 & 57.75 & 36.81 \\
\hline 2017_053 & 52.05204 & 4.17767 & 346.1 & 0.00 & 0.00 & 12.86 & 77.20 & 9.93 \\
\hline 2017_054 & 52.05271 & 4.17636 & 303.7 & 0.00 & 0.08 & 29.27 & 63.25 & 7.40 \\
\hline 2017_055 & 52.05352 & 4.17477 & 405.2 & 0.00 & 0.00 & 10.36 & 59.96 & 29.67 \\
\hline 2017_056 & 52.05407 & 4.17369 & 420.3 & 0.00 & 0.00 & 6.23 & 62.65 & 31.12 \\
\hline 2017_057 & 52.05468 & 4.17250 & 384.8 & 0.00 & 0.00 & 11.83 & 64.34 & 23.83 \\
\hline 2017_058 & 52.05508 & 4.17172 & 355.8 & 0.00 & 0.01 & 19.00 & 61.46 & 19.53 \\
\hline 2017_059 & 52.05577 & 4.17036 & 614.5 & 3.03 & 1.01 & 8.34 & 25.60 & 62.03 \\
\hline 2017_060 & 52.05647 & 4.16901 & 223.4 & 0.00 & 2.78 & 60.69 & 36.35 & 0.18 \\
\hline 2017_061 & 52.05712 & 4.18600 & 425.2 & 0.00 & 0.00 & 7.14 & 59.58 & 33.28 \\
\hline 2017_062 & 52.05768 & 4.18492 & 423.2 & 0.00 & 0.00 & 2.79 & 68.84 & 28.37 \\
\hline 2017_063 & 52.05805 & 4.18419 & 432.4 & 0.00 & 0.00 & 2.29 & 66.76 & 30.95 \\
\hline 2017_064 & 52.05897 & 4.18238 & 309.1 & 0.00 & 0.01 & 25.64 & 68.31 & 6.04 \\
\hline 2017_065 & 52.05985 & 4.18067 & 389.0 & 0.00 & 0.00 & 5.90 & 74.63 & 19.46 \\
\hline 2017_066 & 52.06023 & 4.17993 & 406.8 & 0.00 & 0.00 & 3.84 & 72.60 & 23.56 \\
\hline 2017_067 & 52.06126 & 4.17791 & 407.5 & 0.00 & 0.00 & 6.02 & 67.40 & 26.58 \\
\hline 2017_068 & 52.06177 & 4.17690 & 398.3 & 0.00 & 0.00 & 6.76 & 69.31 & 23.93 \\
\hline 2017_069 & 52.06223 & 4.17601 & 314.3 & 0.00 & 0.05 & 26.18 & 64.51 & 9.25 \\
\hline 2017_070 & 52.06249 & 4.17549 & 320.8 & 0.00 & 0.36 & 28.20 & 54.78 & 16.66 \\
\hline 2017_071 & 52.06100 & 4.19670 & 514.9 & 0.00 & 0.00 & 0.58 & 45.85 & 53.57 \\
\hline 2017_072 & 52.06186 & 4.19502 & 266.2 & 0.00 & 0.39 & 42.10 & 55.55 & 1.96 \\
\hline 2017_073 & 52.06216 & 4.19441 & 287.0 & 0.00 & 0.41 & 35.22 & 58.25 & 6.13 \\
\hline 2017_074 & 52.06261 & 4.19354 & 297.2 & 8.17 & 1.10 & 27.58 & 49.67 & 13.49 \\
\hline 2017_075 & 52.06337 & 4.19204 & 186.9 & 8.78 & 9.77 & 58.32 & 23.10 & 0.04 \\
\hline 2017_076 & 52.06430 & 4.19022 & 231.8 & 0.00 & 1.98 & 57.17 & 40.55 & 0.30 \\
\hline 2017_077 & 52.06531 & 4.18826 & 322.3 & 0.00 & 0.00 & 20.65 & 71.99 & 7.35 \\
\hline 2017_078 & 52.06597 & 4.18696 & 312.2 & 0.00 & 0.00 & 21.77 & 73.98 & 4.24 \\
\hline 2017_079 & 52.06684 & 4.18526 & 280.7 & 0.00 & 0.09 & 35.88 & 61.13 & 2.91 \\
\hline 2017_080 & 52.06779 & 4.18340 & 311.0 & 0.00 & 0.40 & 30.03 & 56.25 & 13.32 \\
\hline 2017_081 & 52.06651 & 4.20875 & 336.4 & 0.00 & 0.00 & 17.95 & 71.40 & 10.65 \\
\hline 2017_082 & 52.06759 & 4.20664 & 228.9 & 0.00 & 2.37 & 58.15 & 39.20 & 0.28 \\
\hline 2017_083 & 52.06787 & 4.20610 & 249.2 & 0.00 & 2.05 & 48.30 & 47.44 & 2.21 \\
\hline 2017_084 & 52.06834 & 4.20517 & 247.1 & 0.00 & 2.44 & 48.81 & 46.51 & 2.24 \\
\hline 2017_085 & 52.06893 & 4.20401 & 198.1 & 11.44 & 9.30 & 47.82 & 30.50 & 0.95 \\
\hline 2017_086 & 52.06936 & 4.20318 & 178.1 & 6.91 & 13.30 & 60.77 & 19.02 & 0.00 \\
\hline 2017_087 & 52.07007 & 4.20179 & 112.9 & 30.53 & 24.44 & 36.16 & 9.01 & 0.00 \\
\hline 2017_088 & 52.07153 & 4.19894 & 200.1 & 0.00 & 9.85 & 61.95 & 27.82 & 0.37 \\
\hline 2017_089 & 52.07347 & 4.19514 & 227.2 & 0.00 & 6.72 & 51.97 & 38.39 & 2.92 \\
\hline 2017_090 & 52.07472 & 4.19268 & 212.8 & 0.00 & 8.50 & 56.65 & 33.77 & 1.07 \\
\hline 2017_091 & 52.07273 & 4.21944 & 312.0 & 0.00 & 0.01 & 25.08 & 67.92 & 6.98 \\
\hline 2017_092 & 52.07329 & 4.21833 & 407.8 & 0.00 & 0.00 & 11.27 & 57.87 & 30.85 \\
\hline 2017_093 & 52.07405 & 4.21684 & 305.5 & 0.00 & 0.15 & 29.46 & 61.70 & 8.68 \\
\hline 2017_094 & 52.07458 & 4.21582 & 240.7 & 0.00 & 2.34 & 51.77 & 44.37 & 1.53 \\
\hline 2017_095 & 52.07515 & 4.21469 & 283.0 & 0.00 & 3.74 & 36.70 & 46.65 & 12.90 \\
\hline
\end{tabular}




\begin{tabular}{|c|c|c|c|c|c|c|c|c|}
\hline StationNr & $\begin{array}{l}\text { Latitude } \\
\text { (WGS84) }\end{array}$ & $\begin{array}{l}\text { Longitude } \\
\text { (WGS84) }\end{array}$ & $\begin{array}{l}\text { Mediaan } \\
\text { ( } \mu \mathrm{m})\end{array}$ & Silt $(\%)$ & $\begin{array}{l}\text { Zeer ffjn } \\
\text { zand }(\%)\end{array}$ & $\begin{array}{l}\text { Fijn zand } \\
(\%)\end{array}$ & $\begin{array}{l}\text { Medium } \\
\text { zand }(\%)\end{array}$ & $\begin{array}{l}\text { Grof zand } \\
\qquad(\%)\end{array}$ \\
\hline 2017_096 & 52.07566 & 4.21370 & 434.8 & 0.30 & 2.90 & 11.74 & 46.70 & 38.38 \\
\hline 2017_097 & 52.07642 & 4.21221 & 295.2 & 0.00 & 2.40 & 34.01 & 51.30 & 12.30 \\
\hline 2017_098 & 52.07794 & 4.20925 & 526.9 & 5.17 & 1.77 & 3.34 & 35.70 & 54.05 \\
\hline 2017_099 & 52.08025 & 4.20472 & 260.4 & 1.14 & 4.41 & 41.04 & 45.66 & 7.76 \\
\hline 2017_100 & 52.08176 & 4.20176 & 353.1 & 0.00 & 0.06 & 19.66 & 61.00 & 19.29 \\
\hline 2017_101 & 52.07948 & 4.22907 & 281.7 & 0.00 & 0.15 & 35.92 & 60.15 & 3.77 \\
\hline 2017_102 & 52.07996 & 4.22814 & 320.2 & 0.00 & 0.12 & 25.97 & 61.80 & 12.12 \\
\hline 2017_103 & 52.08042 & 4.22724 & 415.0 & 0.00 & 0.00 & 3.73 & 69.76 & 26.52 \\
\hline 2017_104 & 52.08113 & 4.22584 & 242.0 & 0.00 & 2.52 & 50.94 & 44.57 & 1.97 \\
\hline 2017_105 & 52.08177 & 4.22460 & 201.6 & 0.00 & 10.76 & 58.91 & 27.70 & 2.64 \\
\hline 2017_106 & 52.08227 & 4.22362 & 234.5 & 0.00 & 5.46 & 50.40 & 39.55 & 4.58 \\
\hline 2017_107 & 52.08305 & 4.22210 & 663.6 & 0.01 & 1.74 & 0.67 & 22.66 & 74.93 \\
\hline 2017_108 & 52.08516 & 4.21796 & 399.9 & 0.00 & 0.43 & 18.16 & 47.74 & 33.66 \\
\hline 2017_109 & 52.08756 & 4.21326 & 248.0 & 0.00 & 5.90 & 44.76 & 41.67 & 7.67 \\
\hline 2017_110 & 52.08896 & 4.21053 & 219.4 & 10.86 & 8.70 & 39.14 & 32.80 & 8.50 \\
\hline 2017_111 & 52.08634 & 4.23850 & 277.9 & 0.00 & 0.48 & 38.16 & 56.78 & 4.58 \\
\hline 2017_112 & 52.08715 & 4.23691 & 622.4 & 0.00 & 0.00 & 1.35 & 29.99 & 68.66 \\
\hline 2017_113 & 52.08752 & 4.23620 & 258.1 & 0.00 & 0.67 & 45.55 & 52.10 & 1.68 \\
\hline 2017_114 & 52.08806 & 4.23513 & 217.2 & 0.00 & 3.54 & 63.00 & 33.32 & 0.13 \\
\hline 2017_115 & 52.08857 & 4.23413 & 216.9 & 0.00 & 7.49 & 55.74 & 33.19 & 3.57 \\
\hline 2017_116 & 52.08930 & 4.23270 & 586.0 & 0.02 & 1.80 & 3.06 & 31.82 & 63.31 \\
\hline 2017_117 & 52.09051 & 4.23034 & 620.7 & 0.01 & 1.39 & 2.85 & 28.72 & 67.03 \\
\hline 2017_118 & 52.09265 & 4.22616 & 359.6 & 0.00 & 0.67 & 22.80 & 51.39 & 25.13 \\
\hline 2017_119 & 52.09369 & 4.22412 & 533.0 & 2.06 & 1.46 & 5.49 & 35.96 & 55.04 \\
\hline 2017_120 & 52.09461 & 4.22232 & 587.0 & 0.32 & 1.26 & 0.54 & 32.89 & 65.01 \\
\hline 2017_121 & 52.00750 & 4.13237 & 328.5 & 0.00 & 0.00 & 20.20 & 70.57 & 9.24 \\
\hline 2017_122 & 52.00744 & 4.13249 & 262.9 & 0.00 & 0.14 & 43.11 & 55.82 & 0.92 \\
\hline 2017_123 & 52.00721 & 4.13294 & 313.8 & 0.00 & 0.08 & 26.76 & 63.42 & 9.73 \\
\hline 2017_124 & 52.00706 & 4.13323 & 252.0 & 0.00 & 0.07 & 48.70 & 51.13 & 0.09 \\
\hline 2017_125 & 52.00700 & 4.13334 & 234.0 & 0.00 & 0.39 & 59.50 & 40.10 & 0.02 \\
\hline 2017_126 & 52.01440 & 4.14171 & 387.6 & 0.00 & 0.00 & 11.10 & 64.76 & 24.13 \\
\hline $2017 \_127$ & 52.01435 & 4.14180 & 465.6 & 0.00 & 0.00 & 1.95 & 56.83 & 41.22 \\
\hline 2017_128 & 52.01418 & 4.14213 & 302.3 & 0.00 & 0.04 & 28.47 & 65.30 & 6.19 \\
\hline 2017_129 & 52.01406 & 4.14237 & 289.8 & 0.00 & 0.00 & 28.64 & 70.18 & 1.18 \\
\hline 2017_130 & 52.01389 & 4.14269 & 264.5 & 0.00 & 0.13 & 42.34 & 56.50 & 1.04 \\
\hline 2017_131 & 52.02157 & 4.15050 & 404.0 & 0.00 & 0.00 & 11.48 & 58.77 & 29.76 \\
\hline 2017_132 & 52.02149 & 4.15067 & 362.9 & 0.00 & 0.00 & 12.45 & 71.42 & 16.13 \\
\hline 2017_133 & 52.02125 & 4.15113 & 303.0 & 0.00 & 0.06 & 28.44 & 65.16 & 6.33 \\
\hline 2017_134 & 52.02111 & 4.15141 & 335.9 & 0.00 & 0.00 & 14.89 & 77.49 & 7.61 \\
\hline 2017_135 & 52.02102 & 4.15158 & 256.4 & 0.00 & 0.09 & 46.10 & 53.64 & 0.17 \\
\hline 2017_136 & 52.02864 & 4.15950 & 345.7 & 0.00 & 0.00 & 19.17 & 64.64 & 16.19 \\
\hline 2017_137 & 52.02861 & 4.15957 & 427.6 & 0.00 & 0.00 & 6.59 & 59.78 & 33.63 \\
\hline 2017_138 & 52.02853 & 4.15973 & 355.7 & 0.00 & 0.00 & 13.90 & 71.60 & 14.50 \\
\hline 2017_139 & 52.02832 & 4.16013 & 335.3 & 0.00 & 0.00 & 12.80 & 81.37 & 5.83 \\
\hline 2017_140 & 52.02826 & 4.16026 & 251.1 & 0.00 & 0.08 & 49.23 & 50.60 & 0.08 \\
\hline 2017_141 & 52.04359 & 4.17593 & 555.0 & 0.00 & 0.00 & 0.14 & 37.35 & 62.51 \\
\hline 2017_142 & 52.04353 & 4.17605 & 513.9 & 0.00 & 0.00 & 0.50 & 46.12 & 53.38 \\
\hline 2017_143 & 52.04348 & 4.17614 & 501.2 & 0.00 & 0.00 & 1.06 & 48.65 & 50.28 \\
\hline 2017_144 & 52.04341 & 4.17629 & 523.9 & 0.00 & 0.00 & 0.51 & 43.85 & 55.64 \\
\hline 2017_145 & 52.04336 & 4.17639 & 508.6 & 0.00 & 0.00 & 0.27 & 47.44 & 52.29 \\
\hline 2017_146 & 52.05053 & 4.18063 & 376.5 & 0.00 & 0.00 & 10.27 & 70.49 & 19.24 \\
\hline 2017_147 & 52.05046 & 4.18077 & 307.8 & 0.00 & 0.00 & 23.62 & 72.33 & 4.04 \\
\hline 2017_148 & 52.05028 & 4.18111 & 318.1 & 0.00 & 0.00 & 19.96 & 75.03 & 5.01 \\
\hline
\end{tabular}




\begin{tabular}{|c|c|c|c|c|c|c|c|c|}
\hline StationNr & $\begin{array}{l}\text { Latitude } \\
\text { (WGS84) }\end{array}$ & $\begin{array}{l}\text { Longitude } \\
\text { (WGS84) }\end{array}$ & $\begin{array}{c}\text { Mediaan } \\
\text { ( } \mu \mathrm{m})\end{array}$ & Silt $(\%)$ & $\begin{array}{c}\text { Zeer fijn } \\
\text { zand }(\%)\end{array}$ & $\begin{array}{c}\text { Fijn zand } \\
(\%)\end{array}$ & $\begin{array}{l}\text { Medium } \\
\text { zand }(\%)\end{array}$ & $\begin{array}{c}\text { Grof zand } \\
\qquad(\%)\end{array}$ \\
\hline 2017_149 & 52.05021 & 4.18126 & 279.7 & 0.00 & 0.00 & 33.49 & 65.75 & 0.76 \\
\hline 2017_150 & 52.05016 & 4.18135 & 287.8 & 0.00 & 0.04 & 32.11 & 65.22 & 2.63 \\
\hline 2017_151 & 52.05683 & 4.18657 & 326.8 & 0.00 & 0.00 & 14.67 & 80.72 & 4.62 \\
\hline 2017_152 & 52.05674 & 4.18676 & 358.0 & 0.00 & 0.00 & 7.63 & 83.11 & 9.26 \\
\hline 2017_153 & 52.05654 & 4.18714 & 340.6 & 0.00 & 0.00 & 19.53 & 66.83 & 13.63 \\
\hline 2017_154 & 52.05647 & 4.18729 & 303.3 & 0.00 & 0.00 & 22.97 & 74.80 & 2.22 \\
\hline 2017_155 & 52.05640 & 4.18741 & 303.1 & 0.00 & 0.00 & 25.45 & 70.90 & 3.65 \\
\hline 2017_156 & 52.06088 & 4.19692 & 369.6 & 0.00 & 0.00 & 6.19 & 82.21 & 11.60 \\
\hline 2017_157 & 52.06083 & 4.19702 & 398.8 & 0.00 & 0.00 & 2.93 & 78.13 & 18.94 \\
\hline 2017_158 & 52.06067 & 4.19734 & 380.1 & 0.00 & 0.00 & 6.48 & 76.96 & 16.57 \\
\hline 2017_159 & 52.06049 & 4.19770 & 391.8 & 0.00 & 0.00 & 5.59 & 74.43 & 19.98 \\
\hline 2017_160 & 52.06021 & 4.19824 & 401.1 & 0.00 & 0.00 & 6.13 & 69.74 & 24.13 \\
\hline 2017_161 & 52.06590 & 4.20994 & 413.9 & 0.00 & 0.00 & 5.23 & 66.95 & 27.82 \\
\hline 2017_162 & 52.06589 & 4.20997 & 478.6 & 0.00 & 0.00 & 1.35 & 54.04 & 44.61 \\
\hline 2017_163 & 52.06584 & 4.21006 & 399.9 & 0.00 & 0.00 & 6.64 & 68.84 & 24.52 \\
\hline 2017_164 & 52.06577 & 4.21020 & 405.8 & 0.00 & 0.00 & 2.48 & 76.61 & 20.91 \\
\hline 2017_165 & 52.06571 & 4.21031 & 403.0 & 0.00 & 0.00 & 3.64 & 74.59 & 21.77 \\
\hline 2017_166 & 52.07225 & 4.22038 & 365.0 & 0.00 & 0.00 & 6.73 & 82.61 & 10.66 \\
\hline 2017_167 & 52.07223 & 4.22041 & 416.2 & 0.00 & 0.00 & 3.22 & 70.39 & 26.39 \\
\hline 2017_168 & 52.07217 & 4.22052 & 467.4 & 0.00 & 0.00 & 0.30 & 60.12 & 39.58 \\
\hline 2017_169 & 52.07203 & 4.22081 & 450.0 & 0.00 & 0.00 & 2.60 & 60.14 & 37.26 \\
\hline 2017_170 & 52.07191 & 4.22104 & 383.4 & 0.00 & 0.00 & 4.33 & 81.18 & 14.49 \\
\hline 2017_171 & 52.07896 & 4.23008 & 379.2 & 0.00 & 0.00 & 5.00 & 81.14 & 13.86 \\
\hline 2017_172 & 52.07894 & 4.23013 & 570.6 & 0.00 & 0.00 & 0.15 & 34.76 & 65.09 \\
\hline 2017_173 & 52.07890 & 4.23021 & 509.3 & 0.00 & 0.00 & 0.07 & 47.16 & 52.77 \\
\hline 2017_174 & 52.07878 & 4.23045 & 471.9 & 0.00 & 0.00 & 0.83 & 57.07 & 42.10 \\
\hline 2017_175 & 52.07864 & 4.23072 & 389.5 & 0.00 & 0.00 & 5.26 & 75.95 & 18.79 \\
\hline 2017_176 & 52.08585 & 4.23946 & 427.5 & 0.00 & 0.00 & 1.25 & 71.61 & 27.13 \\
\hline 2017_177 & 52.08583 & 4.23949 & 437.3 & 0.00 & 0.00 & 0.86 & 69.00 & 30.15 \\
\hline 2017_178 & 52.08569 & 4.23977 & 458.0 & 0.00 & 0.00 & 2.54 & 57.95 & 39.51 \\
\hline 2017_179 & 52.08563 & 4.23988 & 440.1 & 0.00 & 0.00 & 0.78 & 68.28 & 30.94 \\
\hline 2017_180 & 52.08553 & 4.24008 & 387.0 & 0.00 & 0.00 & 5.52 & 76.36 & 18.12 \\
\hline 2017_181 & 52.00687 & 4.13360 & 252.9 & 0.00 & 0.31 & 48.13 & 51.03 & 0.54 \\
\hline 2017_182 & 52.01358 & 4.14331 & 319.2 & 0.00 & 0.09 & 26.01 & 62.42 & 11.48 \\
\hline 2017_183 & 52.02091 & 4.15180 & 341.9 & 0.00 & 0.02 & 20.59 & 63.62 & 15.77 \\
\hline 2017_184 & 52.02809 & 4.16059 & 340.7 & 0.00 & 0.00 & 17.42 & 70.69 & 11.89 \\
\hline 2017_185 & 52.04170 & 4.17963 & 402.2 & 0.00 & 0.00 & 4.40 & 72.97 & 22.63 \\
\hline 2017_186 & 52.04713 & 4.18728 & 425.6 & 0.00 & 0.00 & 8.40 & 57.42 & 34.18 \\
\hline 2017_187 & 52.05273 & 4.19460 & 317.2 & 0.00 & 0.62 & 28.41 & 57.26 & 13.71 \\
\hline 2017_188 & 52.05825 & 4.20207 & 375.9 & 0.20 & 1.95 & 20.29 & 48.57 & 28.98 \\
\hline 2017_189 & 52.06479 & 4.21213 & 391.6 & 0.00 & 0.00 & 7.82 & 69.75 & 22.44 \\
\hline 2017_190 & 52.07148 & 4.22187 & 373.6 & 0.00 & 0.00 & 7.89 & 76.46 & 15.65 \\
\hline 2017_191 & 52.07812 & 4.23173 & 355.6 & 0.00 & 0.00 & 13.23 & 72.92 & 13.85 \\
\hline 2017_192 & 52.08495 & 4.24121 & 348.5 & 0.00 & 0.00 & 15.36 & 71.26 & 13.38 \\
\hline 2017_196 & 52.05972 & 4.19920 & 392.0 & 0.00 & 0.00 & 7.26 & 70.75 & 21.98 \\
\hline 2017_197 & 52.05973 & 4.19919 & 392.9 & 0.00 & 0.00 & 7.25 & 70.44 & 22.31 \\
\hline 2017_198 & 52.05974 & 4.19916 & 379.8 & 0.00 & 0.00 & 9.04 & 71.78 & 19.18 \\
\hline 2017_199 & 52.05975 & 4.19914 & 375.7 & 0.00 & 0.00 & 7.43 & 76.53 & 16.04 \\
\hline 2017_200 & 52.05976 & 4.19912 & 410.5 & 0.00 & 0.00 & 5.33 & 67.81 & 26.86 \\
\hline 2017_201 & 52.05378 & 4.19254 & 362.9 & 2.45 & 0.07 & 16.44 & 59.64 & 21.40 \\
\hline 2017_202 & 52.05376 & 4.19259 & 361.8 & 2.66 & 0.11 & 16.35 & 59.72 & 21.17 \\
\hline 2017_203 & 52.05373 & 4.19264 & 350.5 & 3.07 & 0.13 & 15.89 & 64.24 & 16.69 \\
\hline 2017_204 & 52.05370 & 4.19270 & 367.3 & 0.00 & 0.00 & 12.94 & 68.54 & 18.53 \\
\hline
\end{tabular}




\begin{tabular}{|c|c|c|c|c|c|c|c|c|}
\hline StationNr & $\begin{array}{l}\text { Latitude } \\
\text { (WGS84) }\end{array}$ & $\begin{array}{l}\text { Longitude } \\
\text { (WGS84) }\end{array}$ & $\begin{array}{c}\text { Mediaan } \\
\text { ( } \mu \mathrm{m})\end{array}$ & Silt ( $\%)$ & $\begin{array}{l}\text { Zeer fijn } \\
\text { zand }(\%)\end{array}$ & $\begin{array}{l}\text { Fijn zand } \\
\qquad(\%)\end{array}$ & $\begin{array}{l}\text { Medium } \\
\text { zand }(\%)\end{array}$ & $\begin{array}{l}\text { Grof zand } \\
\qquad(\%)\end{array}$ \\
\hline 2017_205 & 52.05365 & 4.19281 & 345.1 & 3.71 & 1.21 & 21.18 & 52.62 & 21.29 \\
\hline 2017_215 & 52.01140 & 4.13615 & 233.7 & 0.00 & 0.90 & 58.26 & 40.77 & 0.07 \\
\hline 2017_216 & 52.01186 & 4.13525 & 229.3 & 0.00 & 1.22 & 60.22 & 38.46 & 0.10 \\
\hline 2017_217 & 52.01212 & 4.13474 & 280.1 & 0.00 & 0.68 & 37.81 & 54.76 & 6.75 \\
\hline 2017_218 & 52.01354 & 4.13195 & 252.5 & 0.00 & 3.47 & 45.59 & 45.88 & 5.06 \\
\hline 2017_219 & 52.01438 & 4.13032 & 173.6 & 0.01 & 18.62 & 64.80 & 16.56 & 0.01 \\
\hline 2017_221 & 52.01592 & 4.12730 & 176.7 & 2.43 & 22.85 & 49.05 & 23.80 & 1.93 \\
\hline 2017_222 & 52.01824 & 4.12276 & 201.1 & 0.41 & 16.35 & 49.46 & 30.04 & 3.75 \\
\hline 2017_223 & 52.02124 & 4.11687 & 179.9 & 0.47 & 22.67 & 50.59 & 23.70 & 2.62 \\
\hline 2017_224 & 52.02312 & 4.11319 & 178.0 & 0.01 & 19.63 & 59.41 & 20.88 & 0.08 \\
\hline 2017_225 & 52.01850 & 4.14509 & 248.0 & 0.00 & 0.39 & 50.72 & 48.46 & 0.43 \\
\hline 2017_226 & 52.01912 & 4.14389 & 293.3 & 0.00 & 0.42 & 33.45 & 58.64 & 7.50 \\
\hline 2017_227 & 52.01974 & 4.14267 & 260.2 & 0.00 & 0.93 & 44.63 & 51.63 & 2.80 \\
\hline 2017_228 & 52.01989 & 4.14237 & 219.8 & 0.00 & 2.59 & 63.32 & 34.01 & 0.08 \\
\hline 2017_229 & 52.02179 & 4.13865 & 228.2 & 0.00 & 6.37 & 52.11 & 39.23 & 2.30 \\
\hline 2017_230 & 52.02218 & 4.13788 & 236.4 & 0.00 & 5.86 & 49.26 & 41.80 & 3.08 \\
\hline 2017_231 & 52.02272 & 4.13683 & 215.9 & 0.00 & 9.62 & 53.48 & 35.17 & 1.73 \\
\hline 2017_232 & 52.02392 & 4.13449 & 229.3 & 0.02 & 11.57 & 44.71 & 35.90 & 7.81 \\
\hline 2017_233 & 52.02662 & 4.12920 & 211.8 & 1.41 & 15.77 & 43.57 & 29.86 & 9.41 \\
\hline 2017_234 & 52.02861 & 4.12530 & 216.6 & 0.01 & 14.02 & 46.29 & 33.54 & 6.14 \\
\hline 2017_235 & 52.02567 & 4.15390 & 371.9 & 0.00 & 0.27 & 21.00 & 50.33 & 28.39 \\
\hline 2017_236 & 52.02609 & 4.15307 & 389.2 & 0.00 & 0.00 & 14.12 & 58.89 & 26.99 \\
\hline 2017_237 & 52.02653 & 4.15221 & 272.2 & 0.00 & 0.34 & 39.75 & 57.08 & 2.84 \\
\hline 2017_238 & 52.02729 & 4.15074 & 201.9 & 0.00 & 6.37 & 67.71 & 25.89 & 0.02 \\
\hline 2017_239 & 52.02890 & 4.14758 & 272.7 & 0.00 & 2.22 & 39.83 & 50.80 & 7.15 \\
\hline 2017_240 & 52.02927 & 4.14684 & 388.0 & 0.00 & 0.06 & 15.95 & 56.02 & 27.96 \\
\hline 2017_241 & 52.02962 & 4.14617 & 556.7 & 0.00 & 0.00 & 2.23 & 38.18 & 59.60 \\
\hline 2017_242 & 52.03047 & 4.14450 & 456.1 & 0.00 & 0.00 & 7.66 & 50.73 & 41.61 \\
\hline 2017_243 & 52.03233 & 4.14086 & 618.8 & 0.22 & 1.22 & 4.37 & 28.77 & 65.42 \\
\hline 2017_244 & 52.03505 & 4.13553 & 313.9 & 3.73 & 1.76 & 27.72 & 49.32 & 17.47 \\
\hline 2017_245 & 52.03276 & 4.16286 & 306.4 & 0.00 & 0.06 & 27.79 & 64.92 & 7.23 \\
\hline 2017_246 & 52.03392 & 4.16060 & 414.3 & 0.00 & 0.00 & 10.52 & 57.19 & 32.28 \\
\hline 2017_247 & 52.03434 & 4.15977 & 415.6 & 0.00 & 0.00 & 4.86 & 67.13 & 28.01 \\
\hline 2017_248 & 52.03484 & 4.15879 & 243.1 & 0.00 & 2.46 & 50.51 & 45.26 & 1.76 \\
\hline 2017_249 & 52.03573 & 4.15704 & 357.2 & 0.00 & 0.08 & 19.39 & 60.06 & 20.46 \\
\hline 2017_250 & 52.03630 & 4.15593 & 359.0 & 0.00 & 0.04 & 18.82 & 60.55 & 20.59 \\
\hline 2017_251 & 52.03676 & 4.15504 & 317.1 & 0.00 & 0.33 & 28.08 & 58.65 & 12.94 \\
\hline 2017_252 & 52.03755 & 4.15349 & 585.1 & 0.00 & 0.00 & 1.21 & 34.84 & 63.95 \\
\hline 2017_253 & 52.04060 & 4.14752 & 266.5 & 0.00 & 0.89 & 42.16 & 53.64 & 3.31 \\
\hline 2017_254 & 52.04275 & 4.14329 & 291.6 & 0.00 & 1.50 & 34.91 & 52.66 & 10.92 \\
\hline 2017_255 & 52.03649 & 4.16698 & 297.5 & 0.00 & 0.09 & 30.15 & 64.20 & 5.56 \\
\hline 2017_256 & 52.03729 & 4.16542 & 319.4 & 0.00 & 0.25 & 27.24 & 59.82 & 12.69 \\
\hline 2017_257 & 52.03777 & 4.16447 & 285.8 & 0.00 & 0.46 & 35.56 & 58.28 & 5.70 \\
\hline 2017_258 & 52.03825 & 4.16355 & 245.6 & 0.00 & 3.35 & 48.39 & 44.97 & 3.30 \\
\hline 2017_259 & 52.03861 & 4.16283 & 195.1 & 0.00 & 8.02 & 69.28 & 22.69 & 0.01 \\
\hline 2017_260 & 52.03898 & 4.16211 & 187.9 & 0.00 & 15.31 & 59.21 & 21.96 & 3.51 \\
\hline 2017_261 & 52.03942 & 4.16126 & 221.4 & 0.00 & 8.00 & 52.63 & 35.91 & 3.45 \\
\hline 2017_262 & 52.04129 & 4.15759 & 502.0 & 0.00 & 0.00 & 6.02 & 43.66 & 50.32 \\
\hline 2017_263 & 52.04410 & 4.15210 & 264.1 & 0.00 & 2.84 & 42.24 & 47.09 & 7.83 \\
\hline 2017_264 & 52.04568 & 4.14899 & 226.6 & 0.00 & 6.68 & 52.41 & 38.34 & 2.57 \\
\hline 2017_265 & 52.04035 & 4.17085 & 273.8 & 0.00 & 0.75 & 39.74 & 54.71 & 4.79 \\
\hline 2017_266 & 52.04116 & 4.16927 & 384.1 & 0.00 & 0.05 & 15.51 & 57.98 & 26.46 \\
\hline 2017_267 & 52.04166 & 4.16829 & 490.4 & 0.00 & 0.00 & 1.14 & 51.23 & 47.63 \\
\hline
\end{tabular}




\begin{tabular}{|c|c|c|c|c|c|c|c|c|}
\hline StationNr & $\begin{array}{l}\text { Latitude } \\
\text { (WGS84) }\end{array}$ & $\begin{array}{l}\text { Longitude } \\
\text { (wGS84) }\end{array}$ & $\begin{array}{c}\text { Mediaan } \\
(\mu \mathrm{m})\end{array}$ & Silt $(\%)$ & $\begin{array}{c}\text { Zeer fijn } \\
\text { zand }(\%)\end{array}$ & $\begin{array}{c}\text { Fijn zand } \\
(\%)\end{array}$ & $\begin{array}{l}\text { Medium } \\
\text { zand ( } \%)\end{array}$ & $\begin{array}{c}\text { Grof zand } \\
(\%)\end{array}$ \\
\hline 2017_268 & 52.04200 & 4.16762 & 307.6 & 0.00 & 0.19 & 29.00 & 61.77 & 9.04 \\
\hline 2017_269 & 52.04235 & 4.16694 & 204.5 & 0.00 & 7.79 & 62.99 & 29.00 & 0.21 \\
\hline 2017_270 & 52.04274 & 4.16617 & 250.9 & 0.00 & 3.88 & 45.77 & 45.85 & 4.49 \\
\hline 2017_271 & 52.04350 & 4.16468 & 320.5 & 0.00 & 0.07 & 24.88 & 64.22 & 10.83 \\
\hline 2017_272 & 52.04499 & 4.16177 & 225.4 & 0.00 & 6.43 & 53.55 & 38.55 & 1.47 \\
\hline 2017_273 & 52.04736 & 4.15714 & 213.2 & 0.00 & 6.50 & 59.97 & 33.03 & 0.51 \\
\hline 2017_274 & 52.04870 & 4.15450 & 217.3 & 0.00 & 7.71 & 55.49 & 35.23 & 1.58 \\
\hline 2017_275 & 52.04744 & 4.17753 & 421.4 & 0.00 & 0.00 & 7.84 & 59.51 & 32.65 \\
\hline 2017_276 & 52.04822 & 4.17600 & 416.3 & 0.00 & 0.00 & 7.62 & 61.58 & 30.79 \\
\hline 2017_277 & 52.04866 & 4.17516 & 339.5 & 0.00 & 0.00 & 17.38 & 71.28 & 11.35 \\
\hline 2017_278 & 52.04918 & 4.17413 & 242.5 & 0.00 & 2.46 & 50.81 & 45.10 & 1.63 \\
\hline 2017_279 & 52.04956 & 4.17340 & 301.2 & 0.00 & 0.67 & 32.08 & 56.95 & 10.30 \\
\hline 2017_280 & 52.05014 & 4.17225 & 476.9 & 0.00 & 0.00 & 5.58 & 48.83 & 45.59 \\
\hline 2017_281 & 52.05065 & 4.17125 & 277.9 & 6.79 & 6.25 & 30.42 & 40.37 & 16.19 \\
\hline 2017_282 & 52.05171 & 4.16917 & 565.8 & 0.00 & 1.47 & 8.89 & 31.08 & 58.56 \\
\hline 2017_283 & 52.05315 & 4.16635 & 216.6 & 0.00 & 5.24 & 60.12 & 34.18 & 0.45 \\
\hline 2017_284 & 52.05442 & 4.16387 & 287.5 & 0.00 & 2.55 & 36.61 & 44.04 & 16.79 \\
\hline 2017_285 & 52.05408 & 4.18281 & 392.2 & 0.00 & 0.02 & 15.00 & 55.99 & 28.99 \\
\hline 2017_286 & 52.05481 & 4.18139 & 455.3 & 0.00 & 0.00 & 3.98 & 56.12 & 39.90 \\
\hline 2017_287 & 52.05520 & 4.18062 & 435.8 & 0.00 & 0.00 & 0.99 & 69.22 & 29.79 \\
\hline 2017_288 & 52.05638 & 4.17831 & 439.0 & 0.00 & 0.00 & 5.02 & 59.01 & 35.97 \\
\hline 2017_289 & 52.05707 & 4.17696 & 412.8 & 0.00 & 0.00 & 5.17 & 67.25 & 27.58 \\
\hline 2017_290 & 52.05749 & 4.17615 & 398.9 & 0.00 & 0.00 & 6.82 & 68.96 & 24.22 \\
\hline 2017_291 & 52.05784 & 4.17547 & 383.3 & 0.00 & 0.00 & 8.98 & 70.47 & 20.56 \\
\hline 2017_292 & 52.05829 & 4.17458 & 420.7 & 0.00 & 0.00 & 13.79 & 50.05 & 36.16 \\
\hline 2017_293 & 52.05901 & 4.17318 & 647.8 & 1.51 & 1.20 & 1.66 & 25.81 & 69.83 \\
\hline 2017_294 & 52.05934 & 4.17251 & 559.5 & 0.00 & 0.00 & 4.67 & 36.45 & 58.88 \\
\hline 2017_296 & 52.05924 & 4.19096 & 371.9 & 0.00 & 0.00 & 10.18 & 72.54 & 17.28 \\
\hline 2017_297 & 52.05953 & 4.19043 & 360.8 & 0.00 & 0.00 & 15.23 & 67.00 & 17.77 \\
\hline 2017_298 & 52.06115 & 4.18726 & 265.2 & 0.00 & 1.14 & 42.61 & 52.64 & 3.61 \\
\hline 2017_299 & 52.06218 & 4.18524 & 347.4 & 0.00 & 0.00 & 15.29 & 72.09 & 12.62 \\
\hline 2017_300 & 52.06288 & 4.18387 & 374.1 & 0.00 & 0.00 & 7.60 & 76.92 & 15.48 \\
\hline 2017_301 & 52.06349 & 4.18268 & 391.9 & 0.00 & 0.00 & 5.29 & 74.90 & 19.81 \\
\hline 2017_302 & 52.06403 & 4.18162 & 363.1 & 0.00 & 0.00 & 11.94 & 72.23 & 15.83 \\
\hline 2017_303 & 52.06460 & 4.18050 & 340.0 & 0.00 & 0.00 & 17.59 & 70.06 & 12.34 \\
\hline 2017_304 & 52.06502 & 4.17969 & 349.8 & 0.00 & 0.15 & 22.41 & 55.34 & 22.10 \\
\hline 2017_305 & 52.06378 & 4.20268 & 331.7 & 0.00 & 0.00 & 19.33 & 70.73 & 9.94 \\
\hline 2017_306 & 52.06474 & 4.20080 & 220.3 & 0.00 & 4.88 & 58.60 & 36.01 & 0.50 \\
\hline 2017_307 & 52.06499 & 4.20030 & 287.7 & 0.00 & 0.11 & 33.47 & 62.66 & 3.75 \\
\hline 2017_308 & 52.06533 & 4.19964 & 271.7 & 0.00 & 2.16 & 40.11 & 51.24 & 6.48 \\
\hline 2017_309 & 52.06585 & 4.19862 & 175.0 & 0.00 & 17.29 & 66.50 & 16.21 & 0.00 \\
\hline 2017_310 & 52.06636 & 4.19763 & 174.6 & 0.00 & 17.79 & 66.09 & 16.11 & 0.00 \\
\hline 2017_311 & 52.06716 & 4.19607 & 190.0 & 0.00 & 11.76 & 65.99 & 22.25 & 0.00 \\
\hline 2017_312 & 52.06844 & 4.19356 & 211.0 & 5.68 & 6.60 & 53.83 & 33.27 & 0.62 \\
\hline 2017_313 & 52.07018 & 4.19015 & 220.5 & 0.00 & 4.69 & 58.81 & 35.96 & 0.54 \\
\hline 2017_314 & 52.07140 & 4.18780 & 236.9 & 0.00 & 3.08 & 52.59 & 42.52 & 1.81 \\
\hline 2017_315 & 52.06942 & 4.21448 & 442.6 & 0.00 & 0.00 & 3.22 & 61.23 & 35.54 \\
\hline 2017_316 & 52.07046 & 4.21246 & 246.1 & 0.00 & 1.11 & 50.80 & 47.22 & 0.88 \\
\hline 2017_317 & 52.07094 & 4.21151 & 310.9 & 0.00 & 0.15 & 28.22 & 61.30 & 10.33 \\
\hline 2017_318 & 52.07142 & 4.21057 & 254.6 & 0.00 & 1.53 & 46.51 & 49.47 & 2.49 \\
\hline 2017_319 & 52.07198 & 4.20947 & 244.2 & 0.00 & 6.85 & 45.00 & 40.05 & 8.11 \\
\hline 2017_320 & 52.07245 & 4.20856 & 199.5 & 0.00 & 15.52 & 51.63 & 28.35 & 4.50 \\
\hline 2017_321 & 52.07309 & 4.20729 & 194.3 & 6.45 & 16.18 & 44.15 & 28.70 & 4.54 \\
\hline
\end{tabular}




\begin{tabular}{|c|c|c|c|c|c|c|c|c|}
\hline StationNr & $\begin{array}{l}\text { Latitude } \\
\text { (WGS84) }\end{array}$ & $\begin{array}{l}\text { Longitude } \\
\text { (WGS84) }\end{array}$ & $\begin{array}{l}\text { Mediaan } \\
\text { ( } \mu \mathrm{m})\end{array}$ & Silt (\%) & $\begin{array}{l}\text { Zeer fijn } \\
\text { zand }(\%)\end{array}$ & $\begin{array}{c}\text { Fijn zand } \\
(\%)\end{array}$ & $\begin{array}{l}\text { Medium } \\
\text { zand ( } \%)\end{array}$ & $\begin{array}{c}\text { Grof zand } \\
(\%)\end{array}$ \\
\hline 2017_322 & 52.07460 & 4.20435 & 208.3 & 0.00 & 10.67 & 55.53 & 32.27 & 1.53 \\
\hline 2017_323 & 52.07665 & 4.20033 & 294.4 & 1.21 & 3.49 & 32.68 & 49.31 & 13.32 \\
\hline 2017_324 & 52.07800 & 4.19770 & 264.0 & 0.00 & 3.63 & 41.53 & 48.34 & 6.51 \\
\hline 2017_325 & 52.07597 & 4.22452 & 366.1 & 0.00 & 0.00 & 14.95 & 64.99 & 20.06 \\
\hline 2017_326 & 52.07651 & 4.22345 & 332.0 & 0.00 & 0.00 & 21.73 & 65.77 & 12.50 \\
\hline 2017_327 & 52.07708 & 4.22235 & 351.4 & 0.00 & 0.00 & 11.93 & 76.85 & 11.22 \\
\hline 2017_328 & 52.07775 & 4.22103 & 242.9 & 0.00 & 2.65 & 50.39 & 44.82 & 2.14 \\
\hline 2017_329 & 52.07830 & 4.21997 & 439.0 & 0.34 & 0.92 & 9.77 & 50.60 & 38.39 \\
\hline 2017_330 & 52.07877 & 4.21904 & 399.8 & 0.00 & 0.53 & 16.64 & 50.73 & 32.10 \\
\hline 2017_331 & 52.07997 & 4.21669 & 492.5 & 0.29 & 0.76 & 6.94 & 43.26 & 48.75 \\
\hline 2017_332 & 52.08169 & 4.21333 & 492.3 & 0.00 & 0.01 & 8.24 & 42.99 & 48.76 \\
\hline 2017_333 & 52.08412 & 4.20857 & 237.0 & 0.00 & 5.57 & 49.34 & 41.55 & 3.55 \\
\hline 2017_334 & 52.08575 & 4.20537 & 253.7 & 0.00 & 3.87 & 44.80 & 45.78 & 5.54 \\
\hline 2017_335 & 52.08281 & 4.23399 & 361.8 & 0.00 & 0.00 & 18.42 & 59.47 & 22.11 \\
\hline 2017_336 & 52.08348 & 4.23268 & 421.8 & 0.00 & 0.02 & 12.30 & 52.18 & 35.50 \\
\hline 2017_337 & 52.08402 & 4.23161 & 303.2 & 0.00 & 0.01 & 27.49 & 67.14 & 5.36 \\
\hline 2017_338 & 52.08465 & 4.23037 & 232.8 & 0.00 & 5.53 & 51.14 & 40.38 & 2.96 \\
\hline 2017_339 & 52.08504 & 4.22961 & 195.6 & 0.00 & 9.50 & 66.01 & 24.48 & 0.01 \\
\hline 2017_340 & 52.08535 & 4.22901 & 704.4 & 0.00 & 3.42 & 7.58 & 15.95 & 73.05 \\
\hline 2017_341 & 52.08675 & 4.22628 & 591.3 & 0.00 & 0.00 & 1.81 & 33.69 & 64.50 \\
\hline 2017_342 & 52.08879 & 4.22228 & 575.7 & 0.00 & 0.00 & 0.85 & 35.54 & 63.61 \\
\hline 2017_343 & 52.09078 & 4.21839 & 240.8 & 13.24 & 6.12 & 33.14 & 37.61 & 9.95 \\
\hline 2017_344 & 52.09170 & 4.21660 & 238.4 & 0.00 & 5.71 & 48.43 & 39.47 & 6.39 \\
\hline
\end{tabular}




\section{Bijlage 5 Verspreiding enkele bodemdiersoorten uit de bodemschaaf}

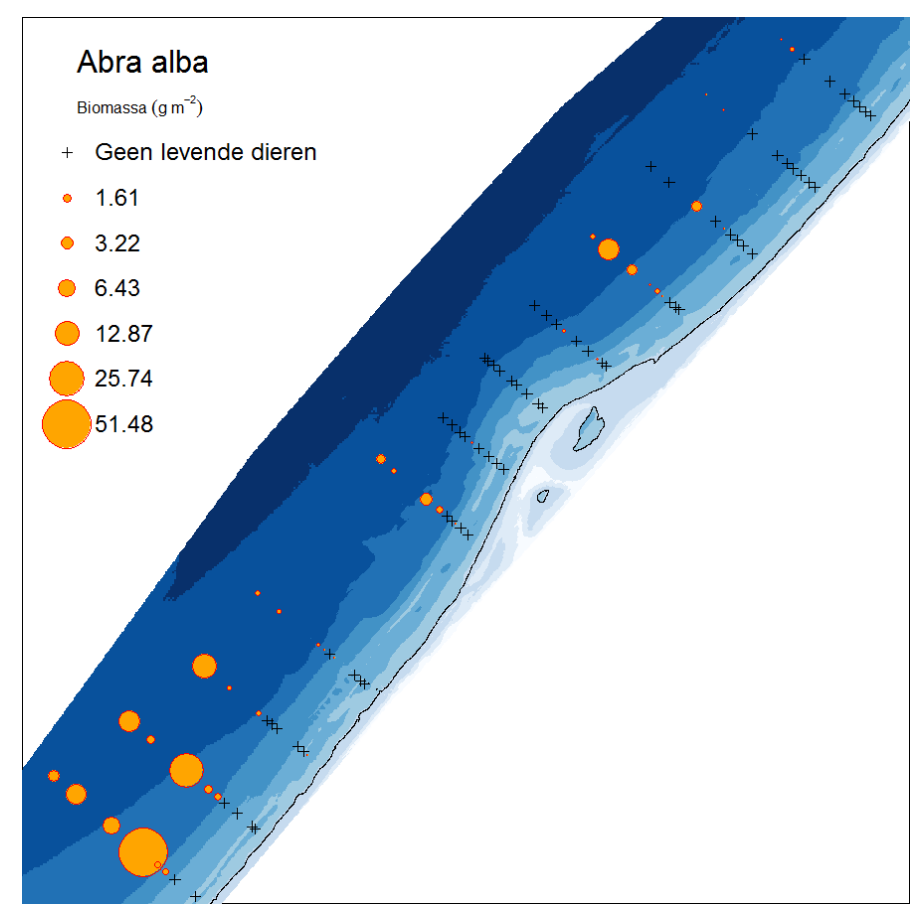

Figuur 59: Verspreidingskaart Abra alba ( $\mathrm{g}$ versgewicht $\mathrm{m}^{-2}$ ) bemonsterd met de bodemschaaf in 2017.

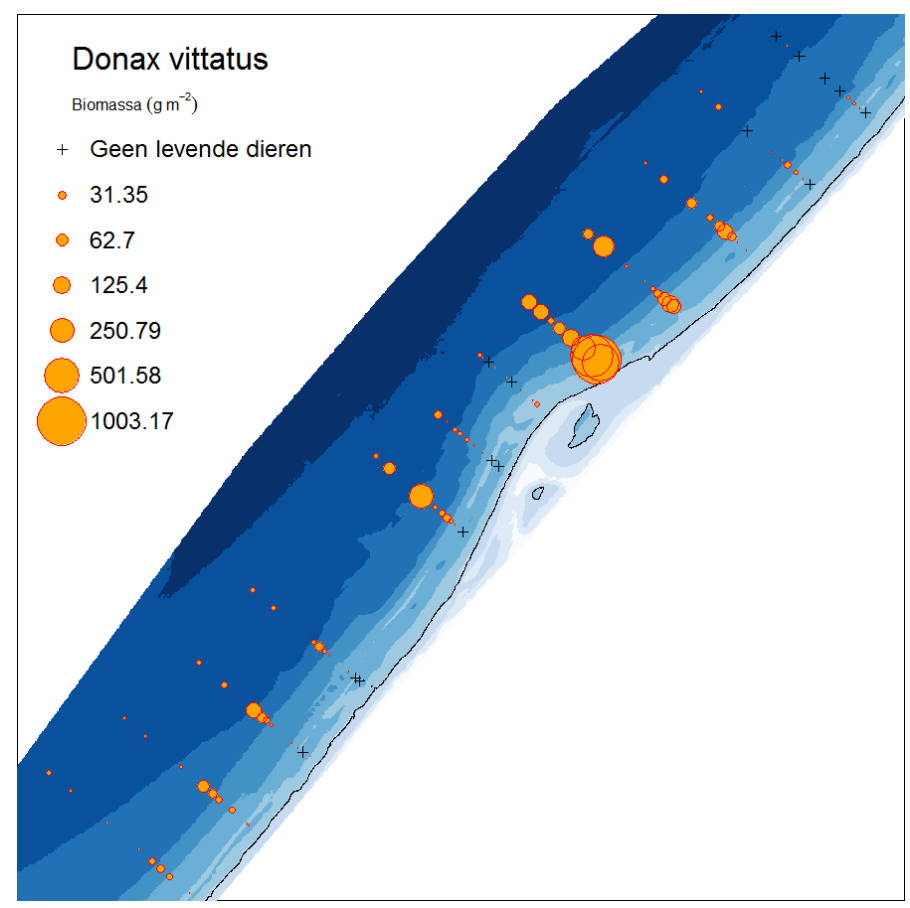

Figuur 60: Verspreidingskaart Donax vittatus ( $\mathrm{g}$ versgewicht $\mathrm{m}^{-2}$ ) bemonsterd met de bodemschaaf in 2017. 


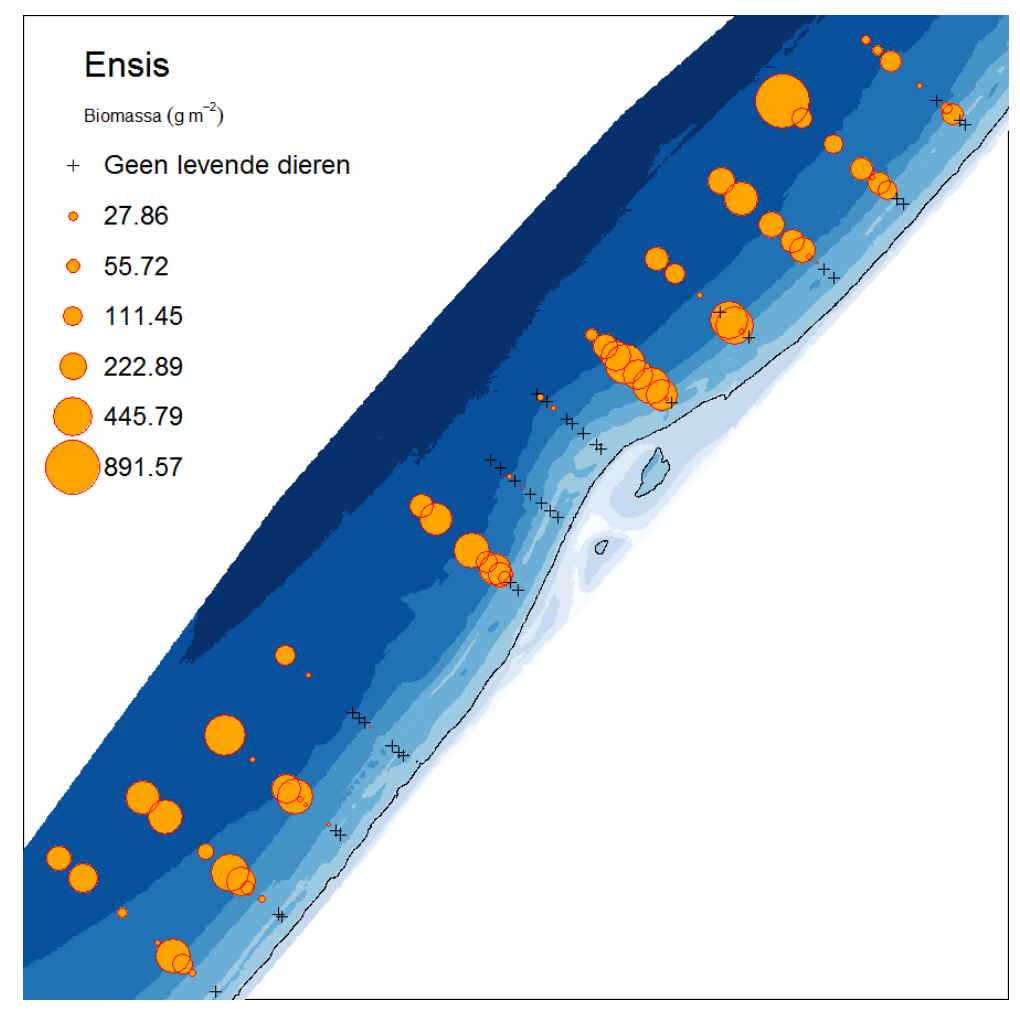

Figuur 61: Verspreidingskaart Ensis spp. ( $\mathrm{g}$ versgewicht $\mathrm{m}^{-2}$ ) bemonsterd met de bodemschaaf in 2017.

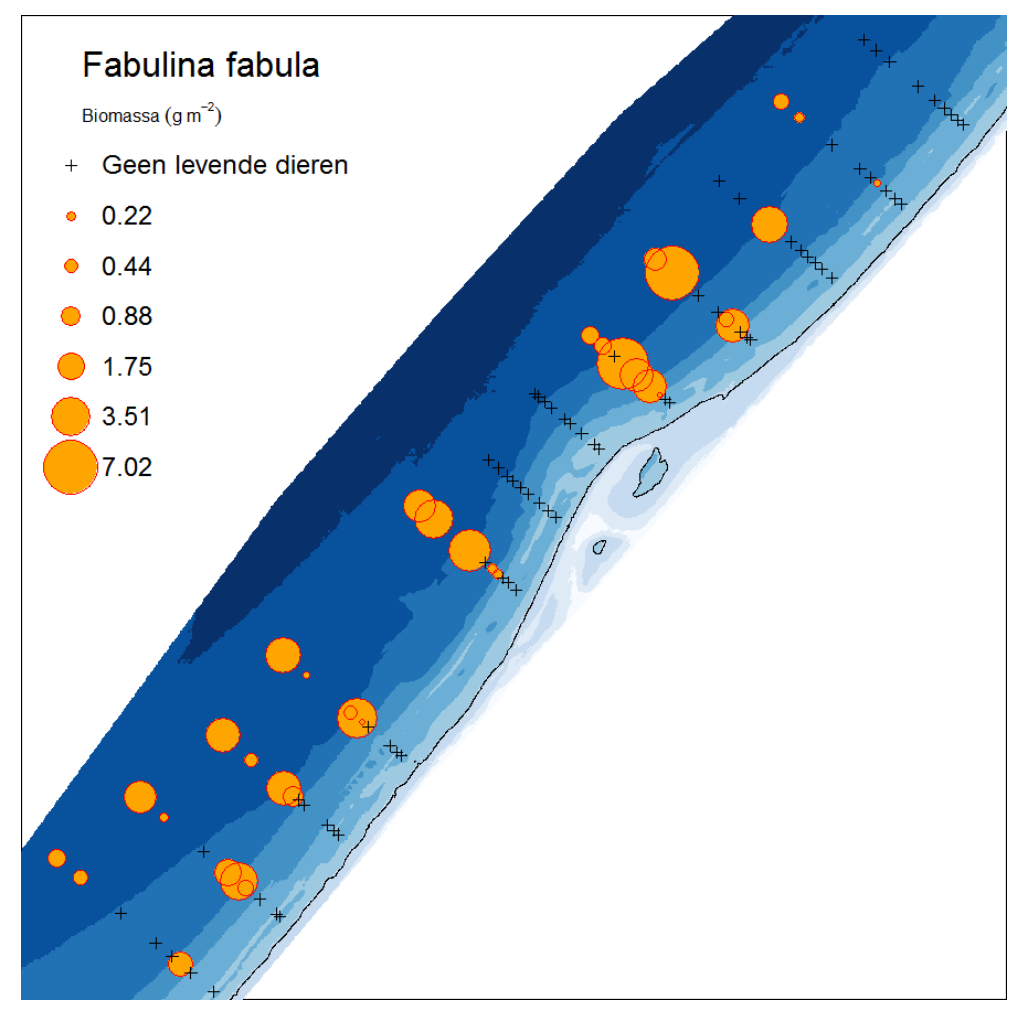

Figuur 62: Verspreidingskaart Fabulina fabula ( $\mathrm{g}$ versgewicht $\mathrm{m}^{-2}$ ) bemonsterd met de bodemschaaf in 2017. 


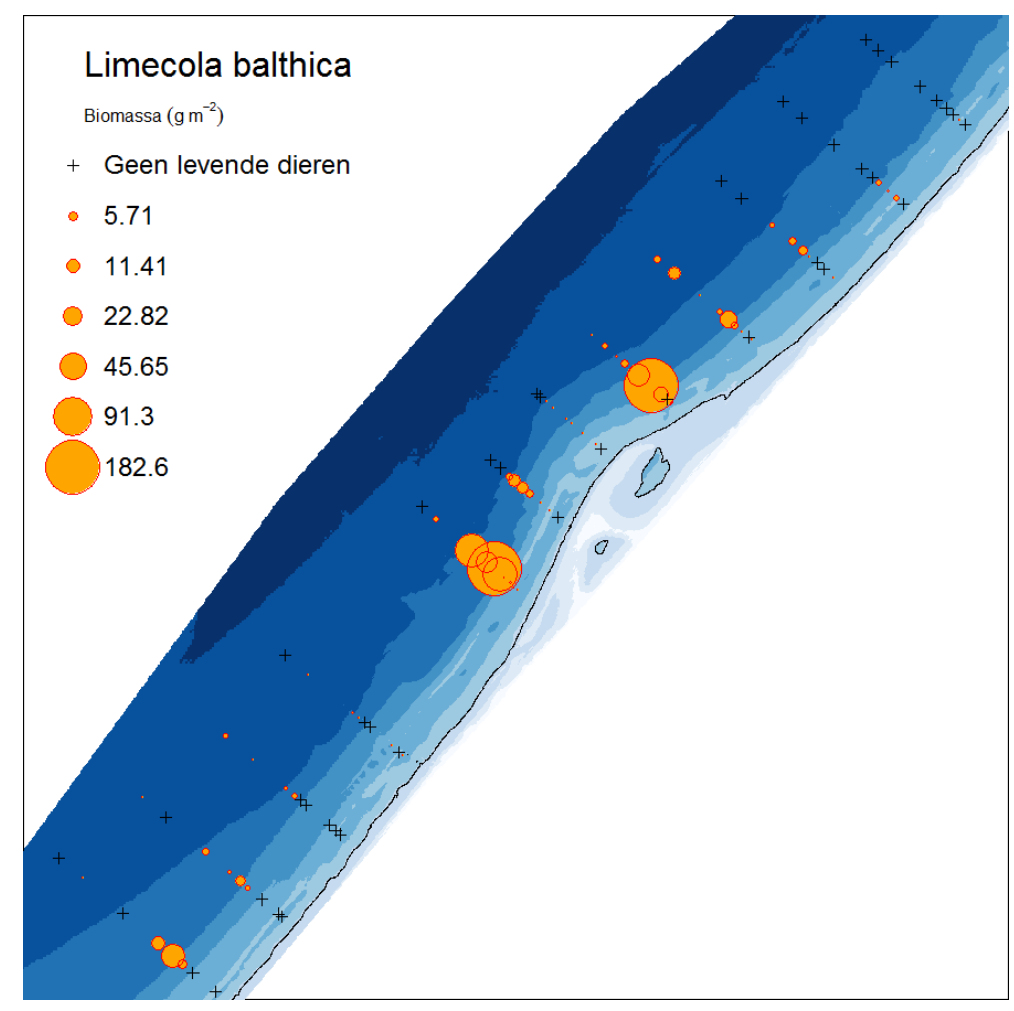

Figuur 63: Verspreidingskaart Limecola balthica ( $\mathrm{g}$ versgewicht $\mathrm{m}^{-2}$ ) bemonsterd met de bodemschaaf in 2017.

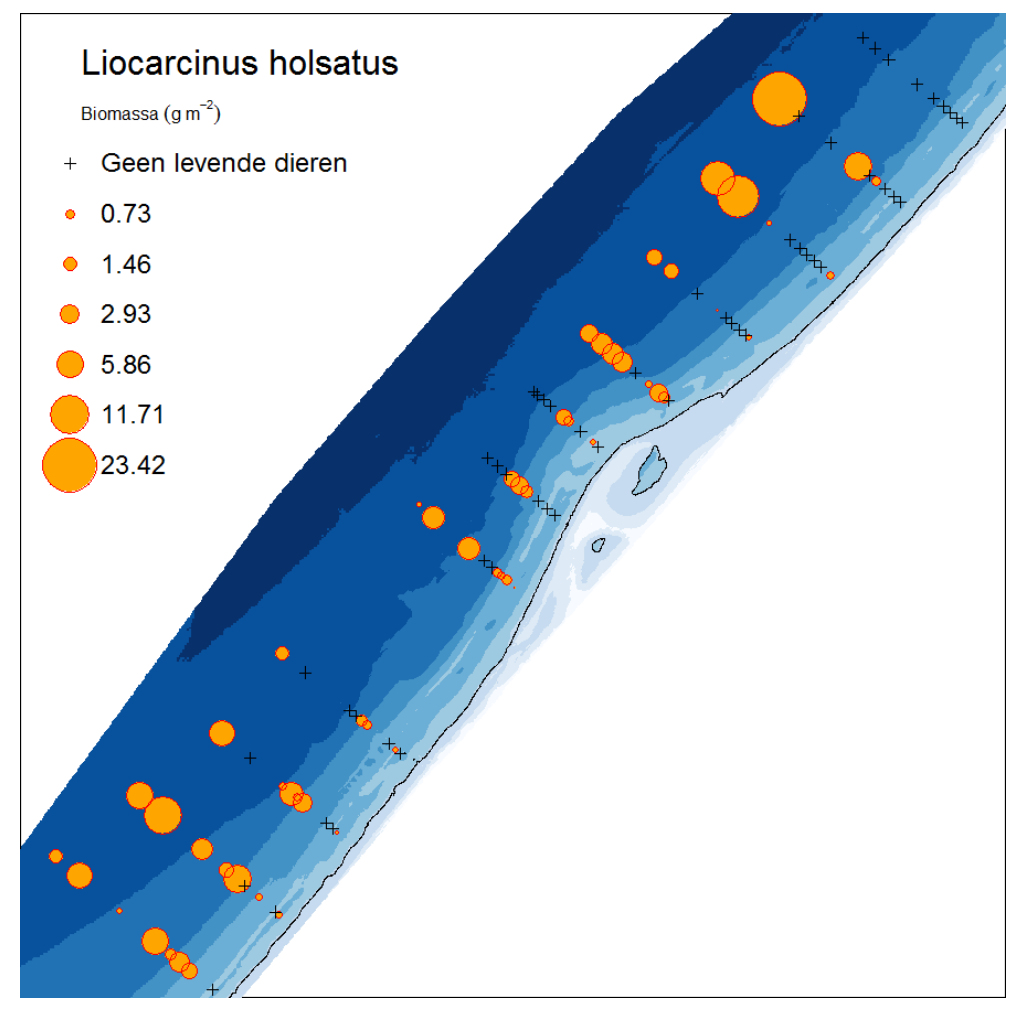

Figuur 64: Verspreidingskaart Liocarcinus holsatus ( $\mathrm{g}$ versgewicht $\mathrm{m}^{-2}$ ) bemonsterd met de bodemschaaf in 2017. 


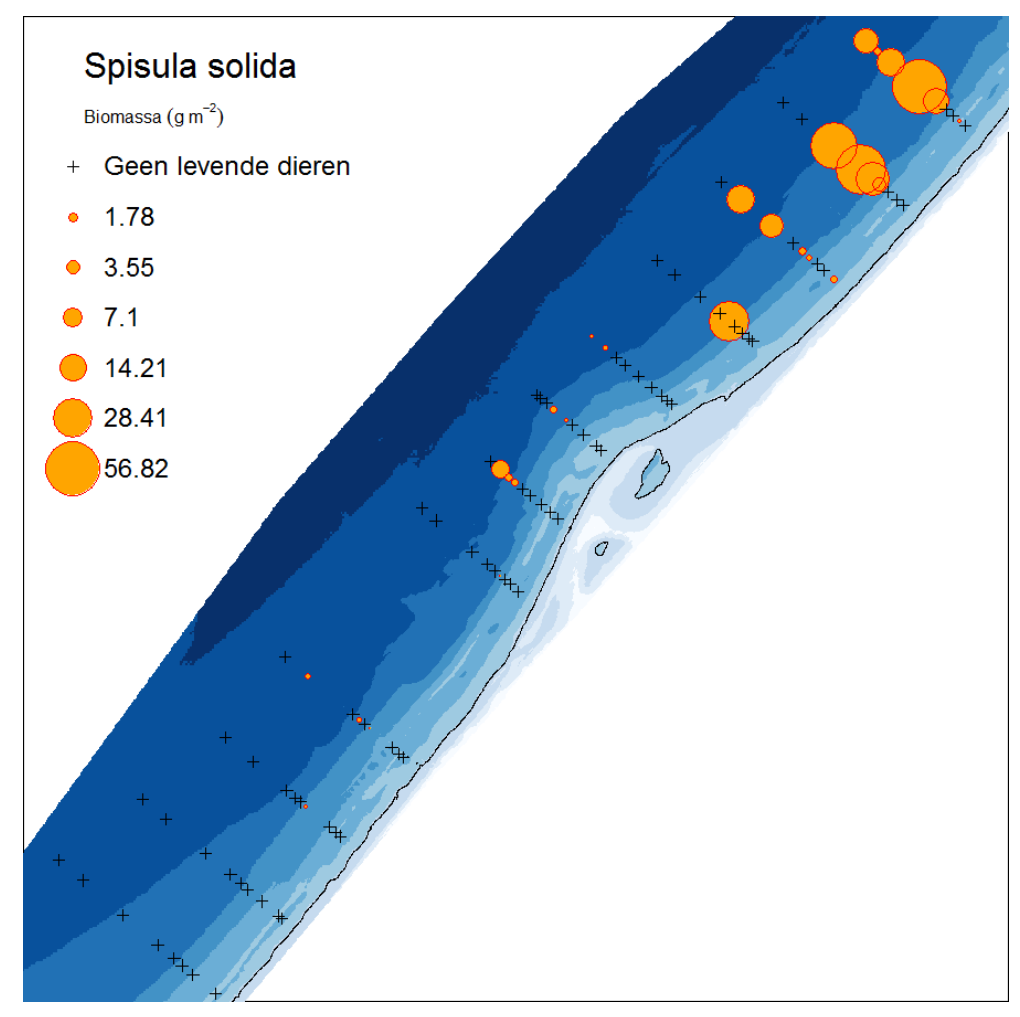

Figuur 65: Verspreidingskaart Spisula solida ( $\mathrm{g}$ versgewicht $\mathrm{m}^{-2}$ ) bemonsterd met de bodemschaaf in 2017.

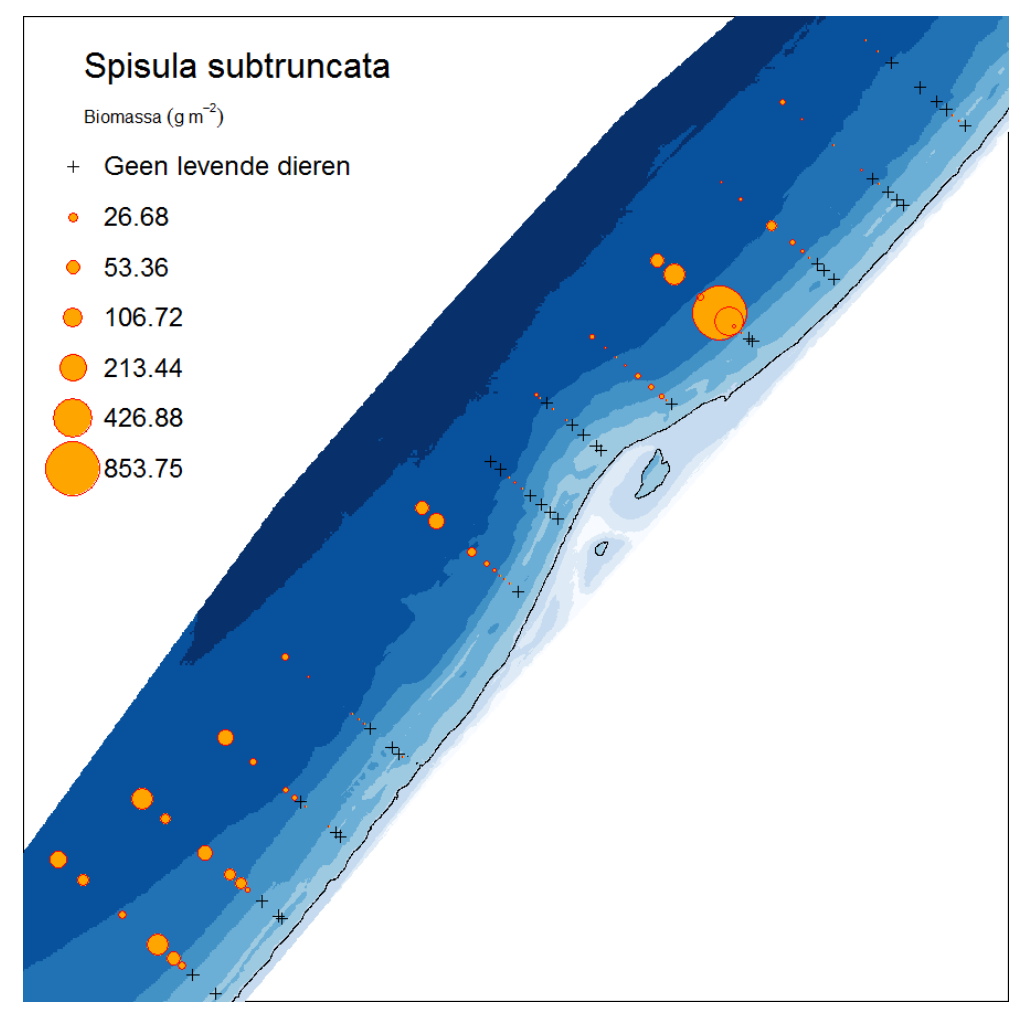

Figuur 66: Verspreidingskaart Spisula subtruncata ( $\mathrm{g}$ versgewicht $\mathrm{m}^{-2}$ ) bemonsterd met de bodemschaaf in 2017. 


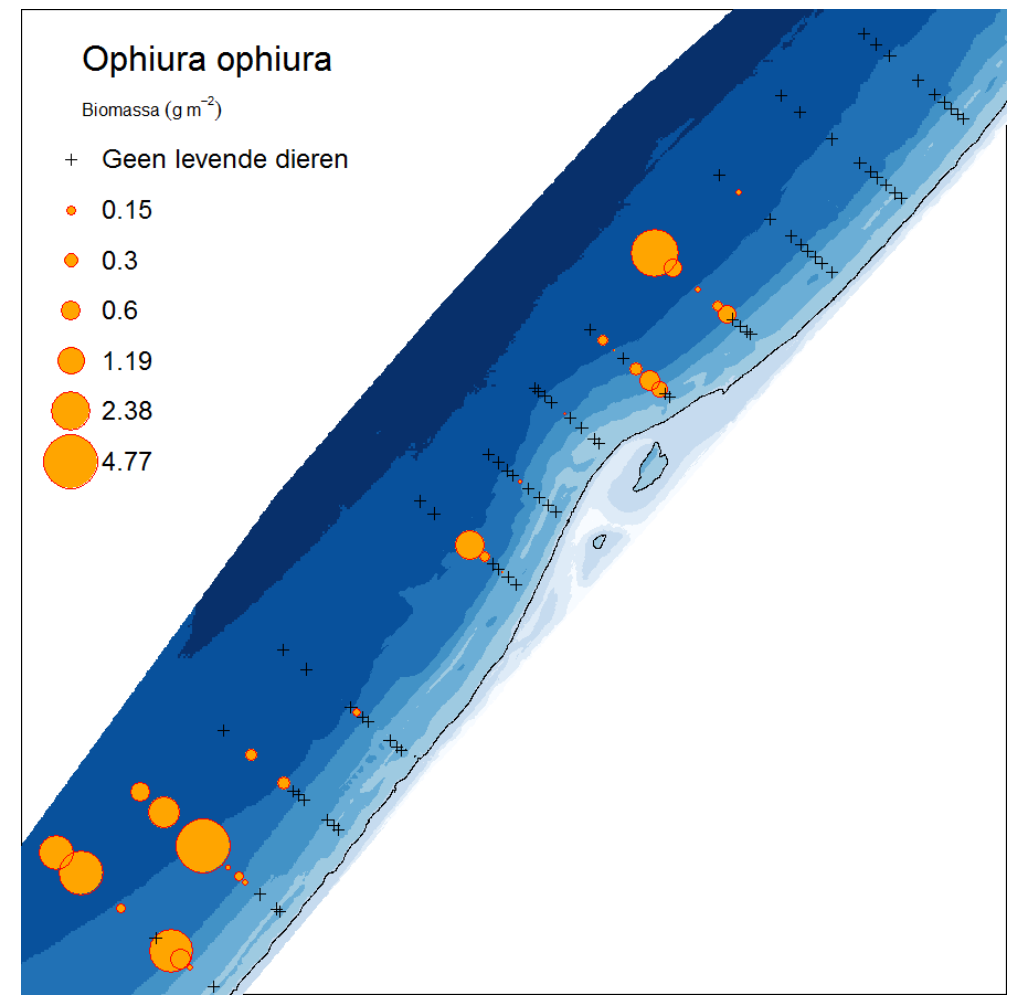

Figuur 67: Verspreidingskaart Ophiura ophiura ( $\mathrm{g}$ versgewicht $\mathrm{m}^{-2}$ ) bemonsterd met de bodemschaaf in 2017.

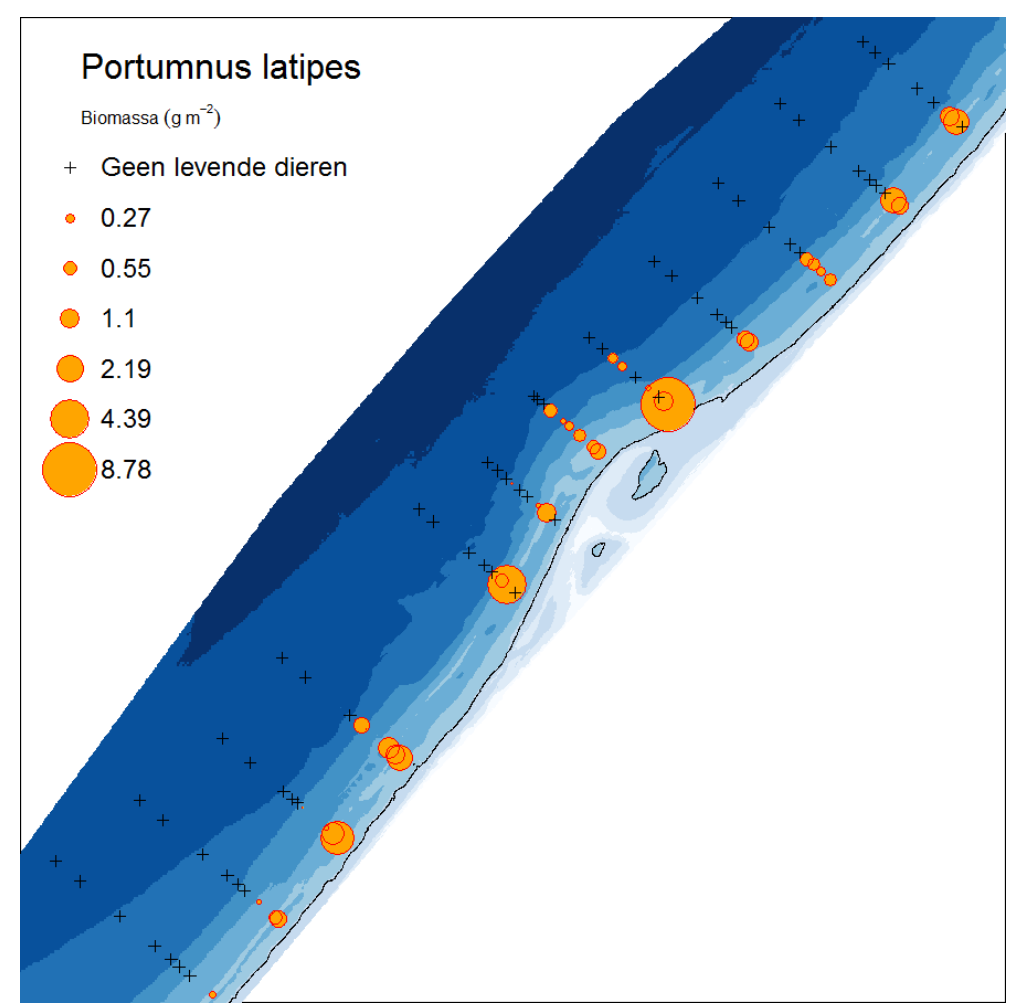

Figuur 68: Verspreidingskaart Portumnus latipes ( $\mathrm{g}$ versgewicht $\mathrm{m}^{-2}$ ) bemonsterd met de bodemschaaf in 2017. 


\section{Bijlage 6 Clusteranalyse data bodemschaaf voorgaande jaren}
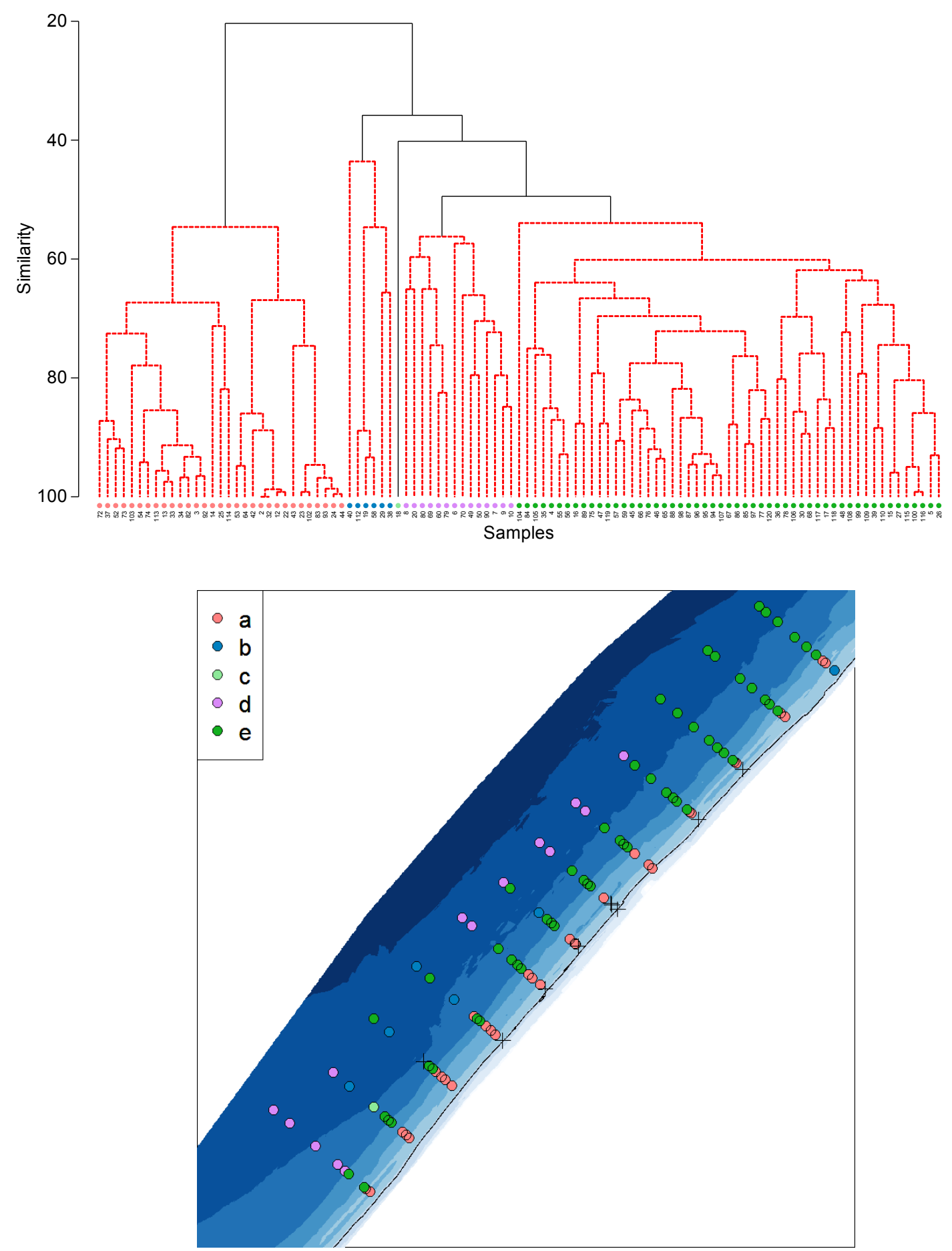

Figuur 69: Clusteranalyse data bodemschaaf 2010. Bovenste plot het dendrogram. Zwarte lijnen van het dendrogram geven de significante $(p<0.05)$ clusters weer. De markers geven de verschillende clusters. Onderste plot: de ruimtelijke verdeling van de clusters over het gebied. 

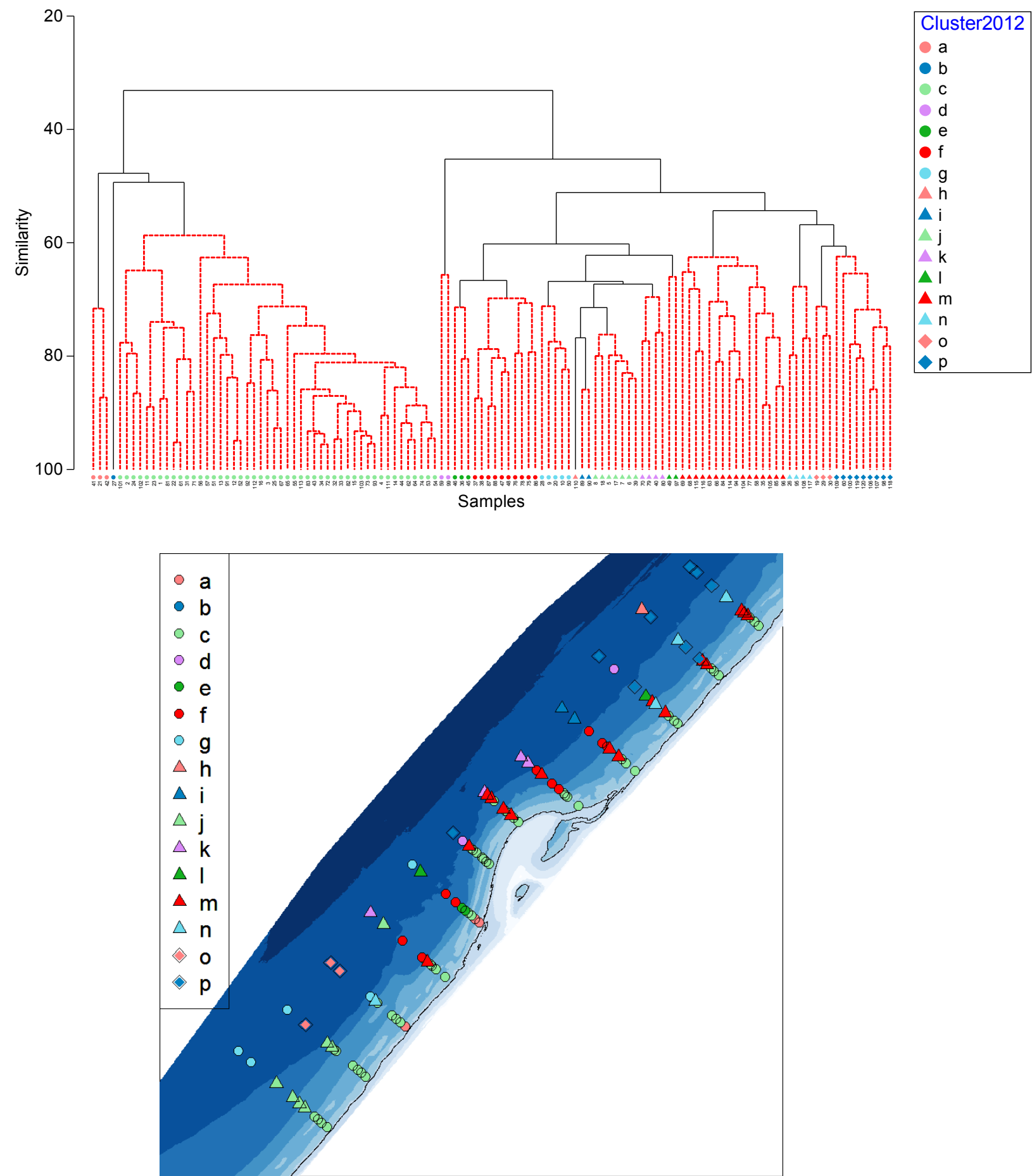

Figuur 70: Clusteranalyse data bodemschaaf 2012. Bovenste plot het dendrogram. Zwarte lijnen van het dendrogram geven de significante $(p<0.05)$ clusters weer. De markers geven de verschillende clusters. Onderste plot: de ruimtelijke verdeling van de clusters over het gebied. 

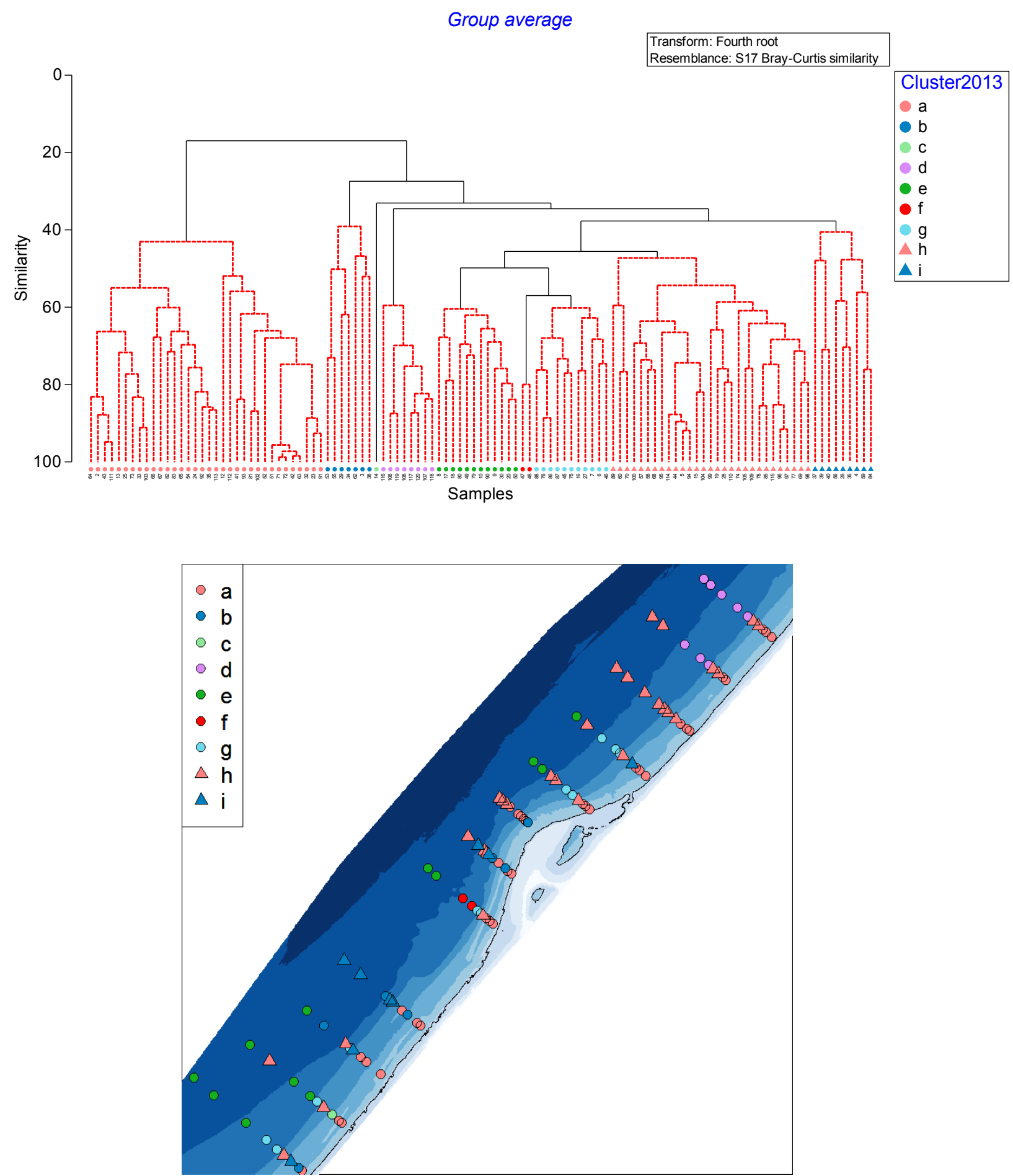

Figuur 71: Clusteranalyse data bodemschaaf 2013. Bovenste plot het dendrogram. Zwarte lijnen van het dendrogram geven de significante $(p<0.05)$ clusters weer. De markers geven de verschillende clusters. Onderste plot: de ruimtelijke verdeling van de clusters over het gebied. 

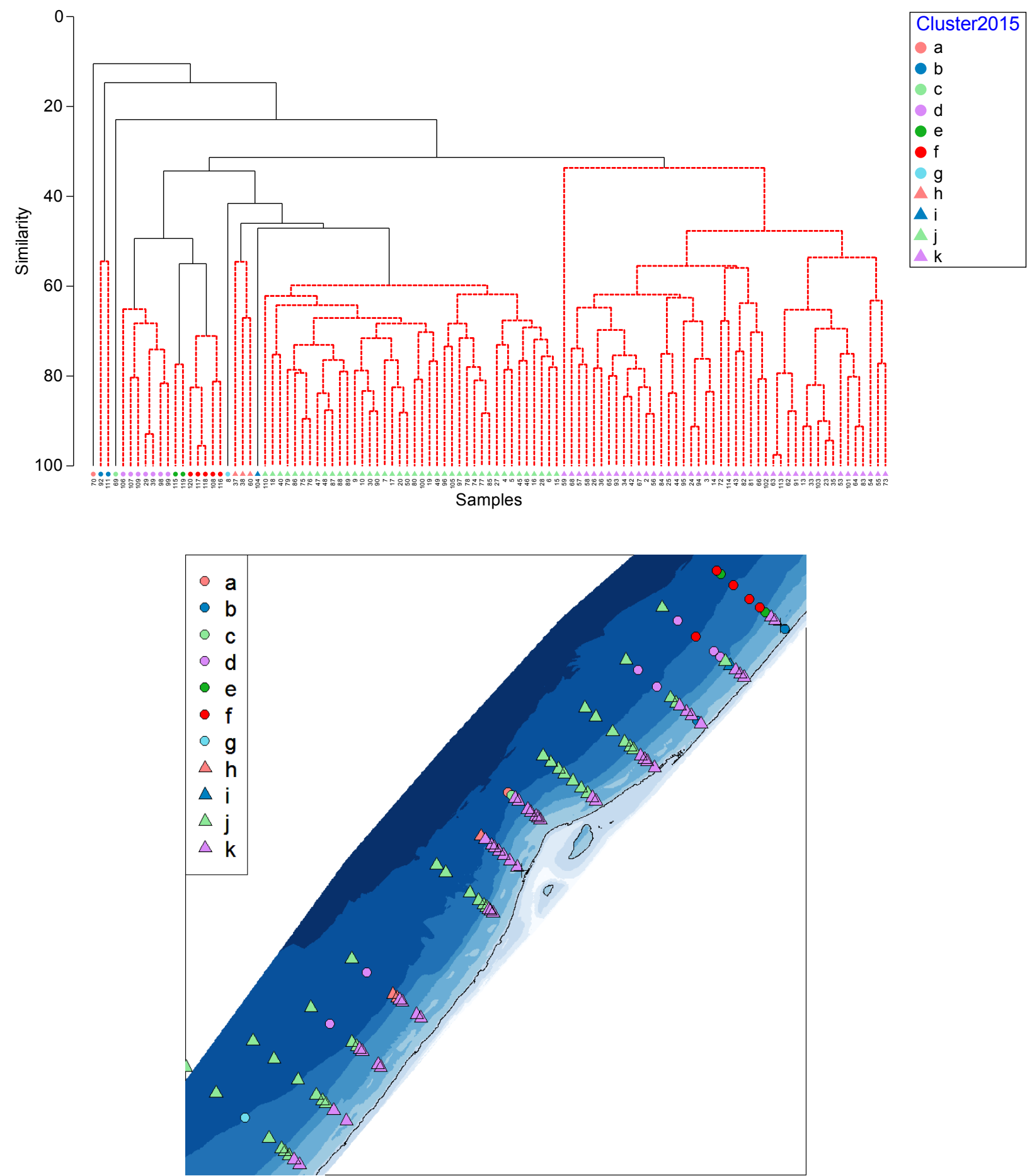

Figuur 72: Clusteranalyse data bodemschaaf 2015. Bovenste plot het dendrogram. Zwarte lijnen van het dendrogram geven de significante $(p<0.05)$ clusters weer. De markers geven de verschillende clusters. Onderste plot: de ruimtelijke verdeling van de clusters over het gebied. 


\section{Bijlage 7 Verspreiding enkele bodemdiersoorten uit de Van Veen bemonstering}

In onderstaande figuren zijn de verspreidingskaarten gepresenteerd van een aantal kenmerkende bodemdiersooren uit de Van Veen bemonstering over de jaren 2010, 2012, 2013, 2015 en 2017. Deze figuren geven een beeld van de ruimtelijke en temporele ontwikkeling van de betreffende soorten.

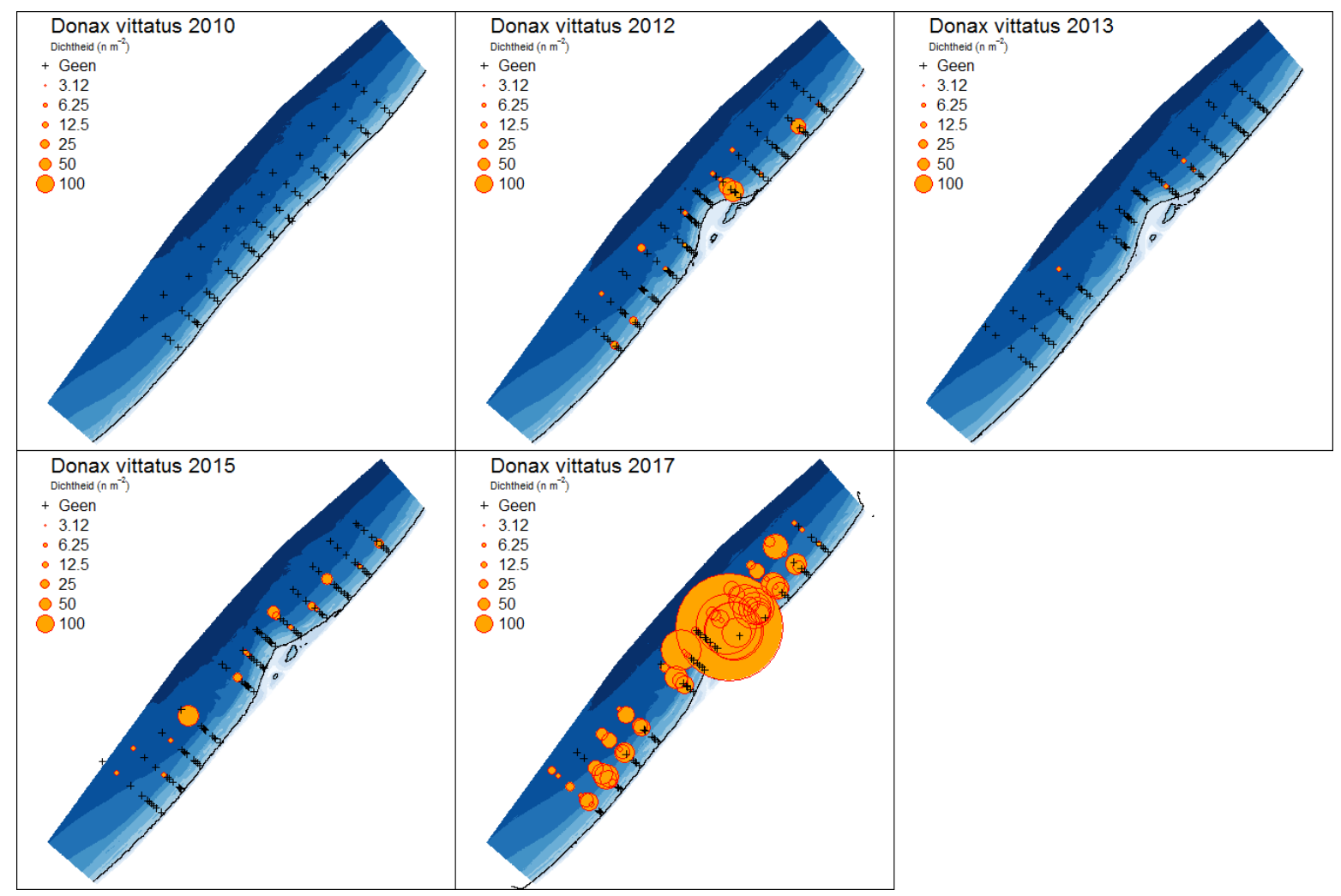

Figuur 73: Verspreidingskaarten Donax vittatus (aantal $\mathrm{m}^{-2}$ ) uit de Van Veen bemonstering over de jaren 2010 tot en met 2017. 


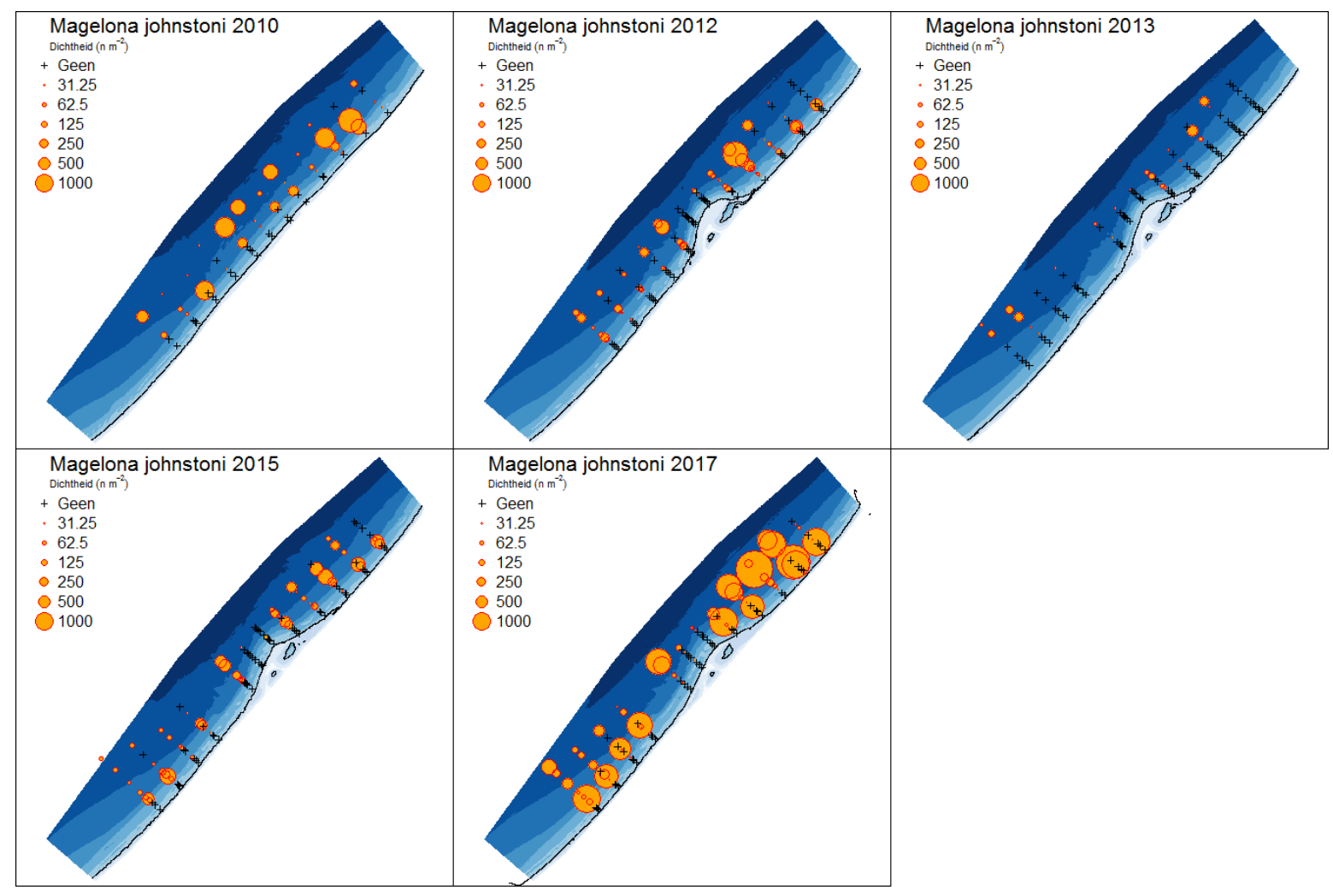

Figuur 74: Verspreidingskaarten Magelona johnstoni (aantal $\mathrm{m}^{-2}$ ) uit de Van Veen bemonstering over de jaren 2010 tot en met 2017.

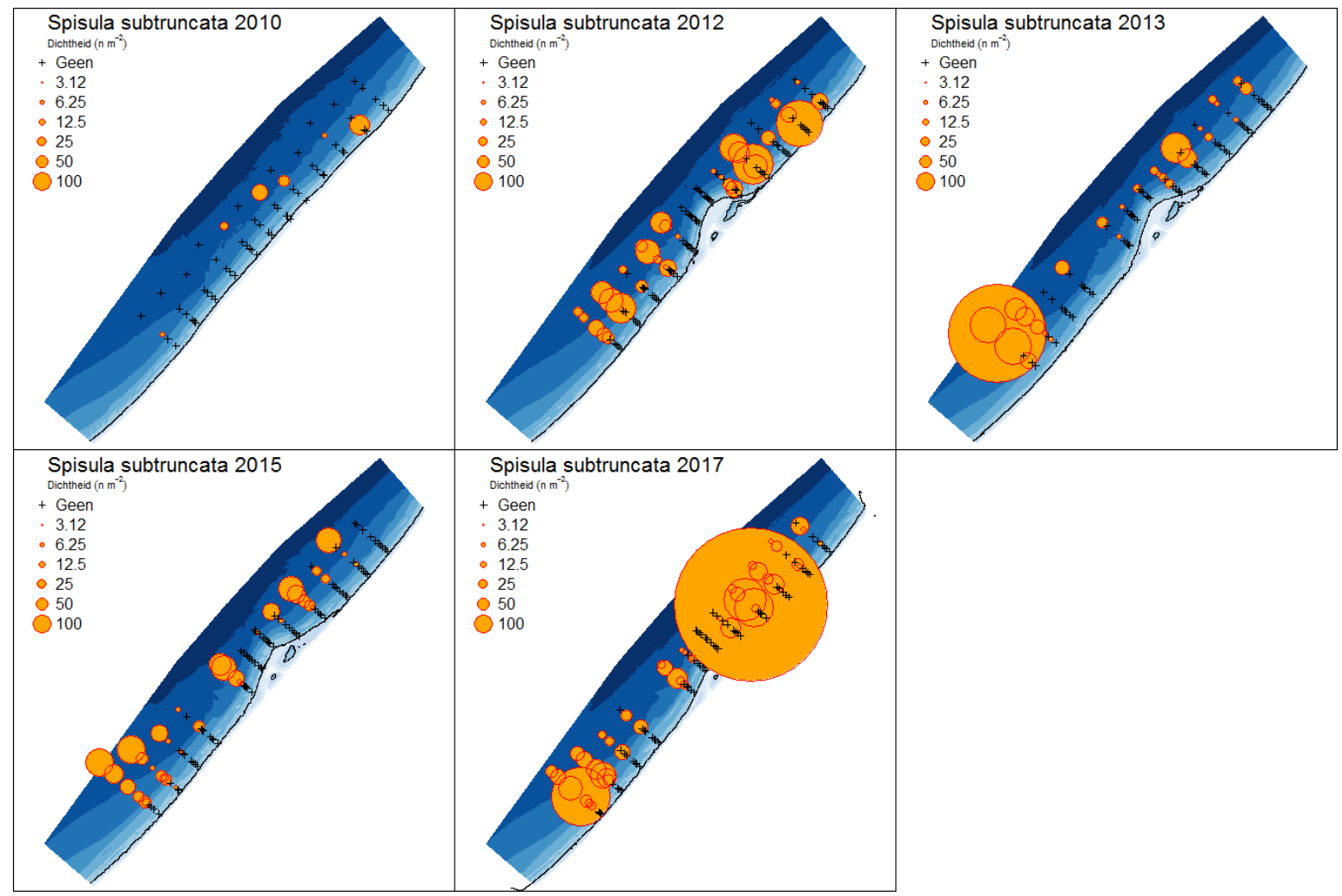

Figuur 75: Verspreidingskaarten Spisula subtruncata (aantal $\mathrm{m}^{-2}$ ) uit de Van Veen bemonstering over de jaren 2010 tot en met 2017. 


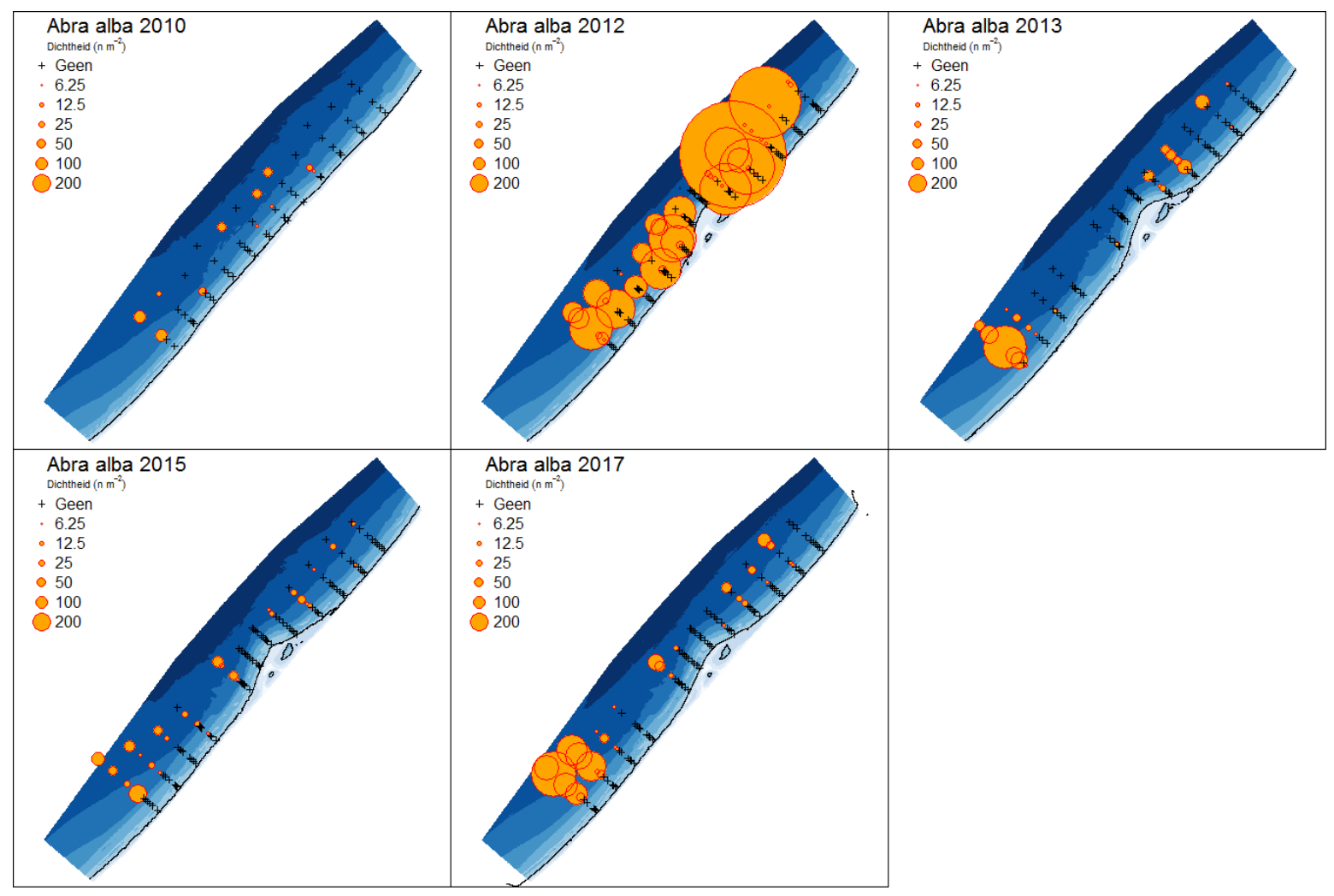

Figuur 76: Verspreidingskaarten Abra alba (aantal $\mathrm{m}^{-2}$ ) uit de Van Veen bemonstering over de jaren 2010 tot en met 2017.

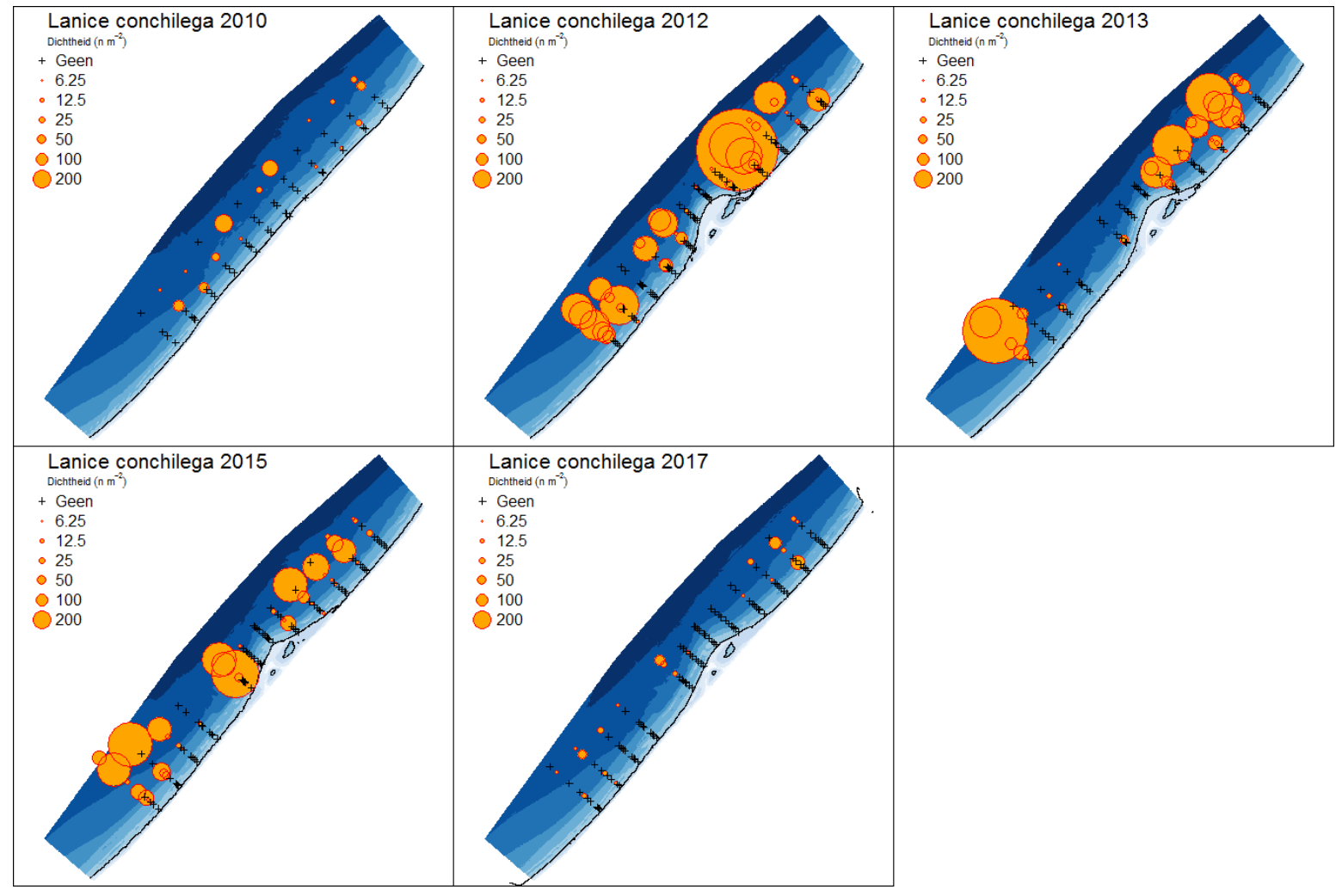

Figuur 77: Verspreidingskaarten Lanice conchilega (aantal $\mathrm{m}^{-2}$ ) uit de Van Veen bemonstering over de jaren 2010 tot en met 2017. 


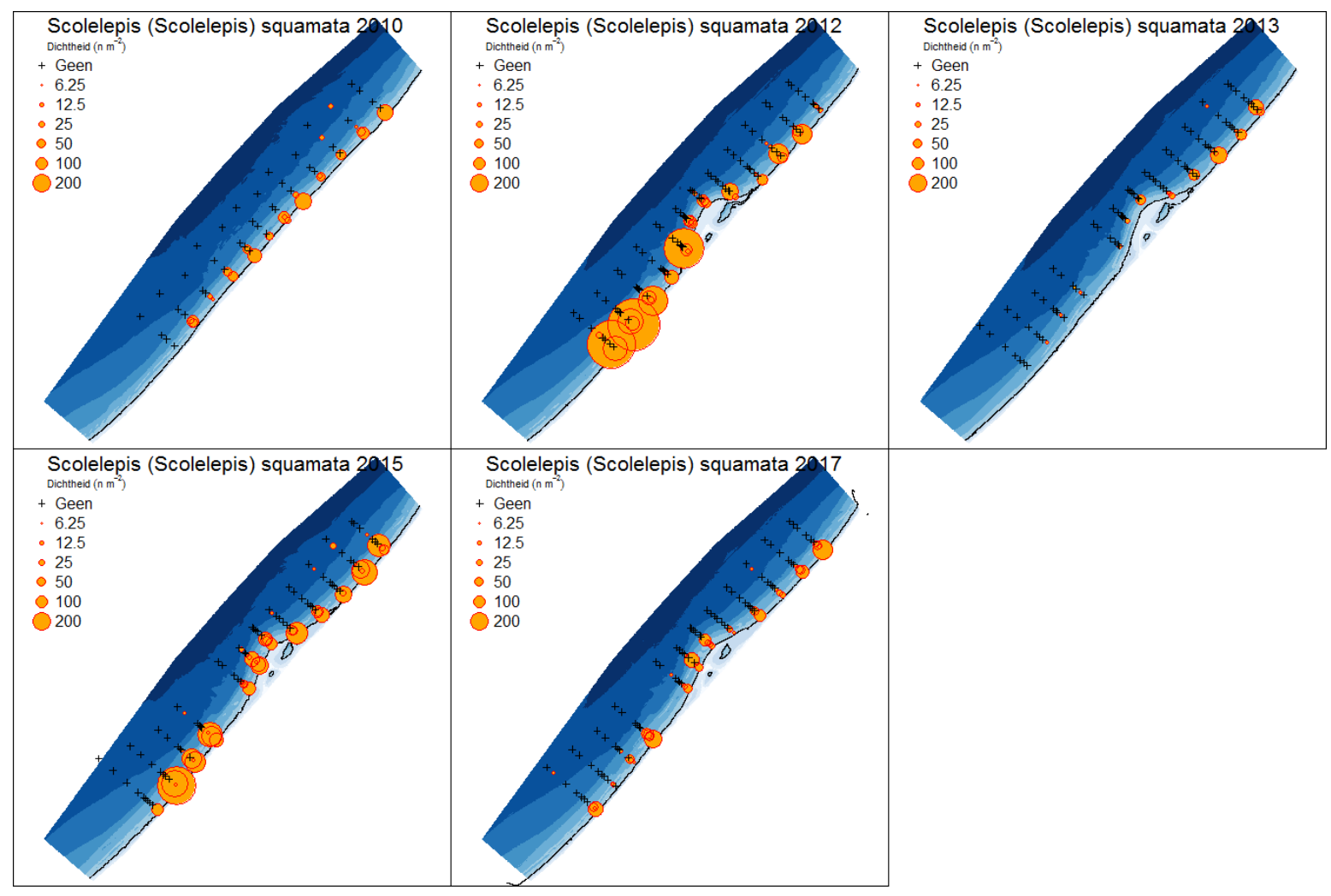

Figuur 78: Verspreidingskaarten Scolelepis (Scolelepis) squamata (aantal $\mathrm{m}^{-2}$ ) uit de Van Veen bemonstering over de jaren 2010 tot en met 2017.

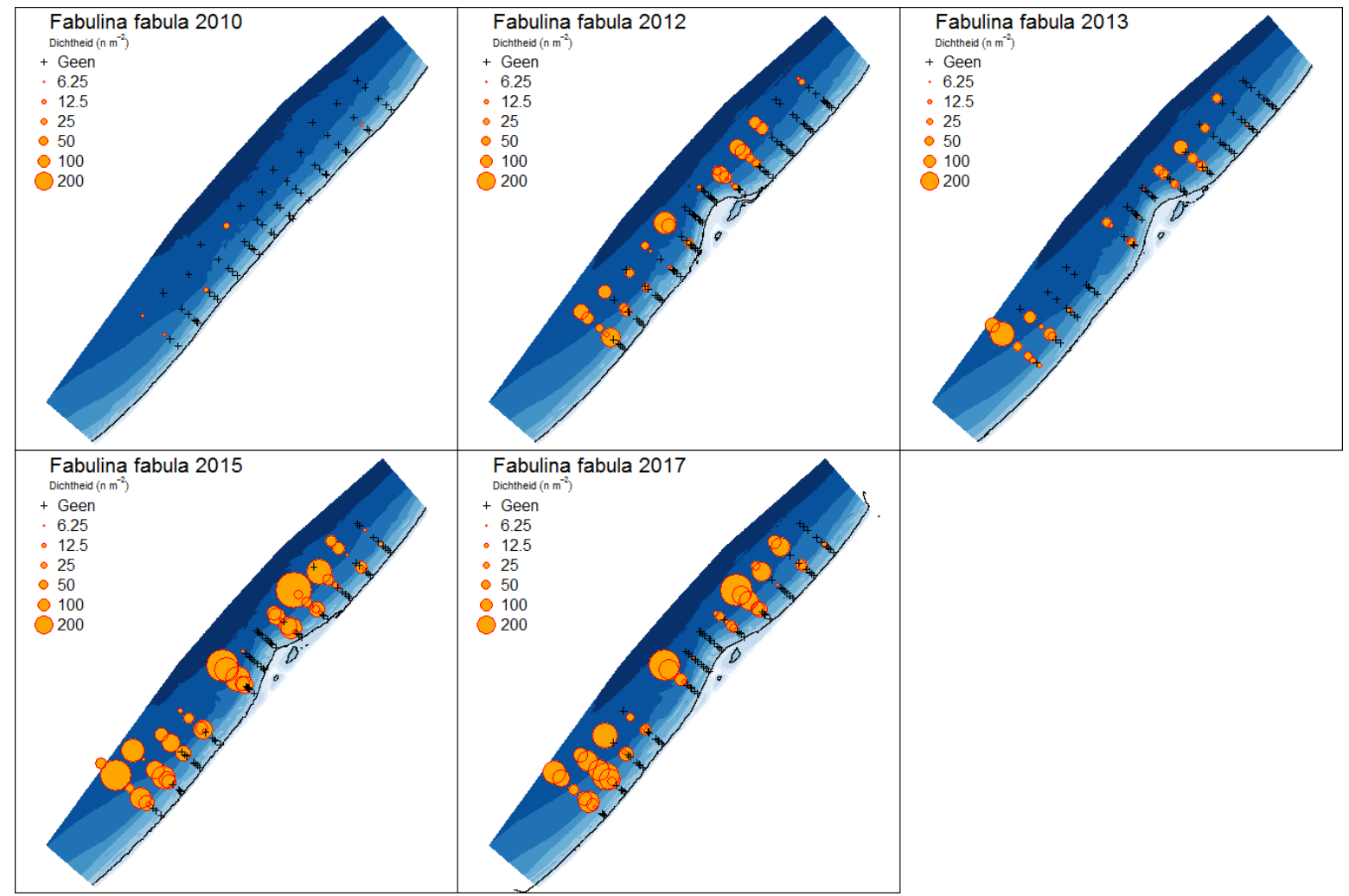

Figuur 79: Verspreidingskaarten Fabulina fabula (aantal $\mathrm{m}^{-2}$ ) uit de Van Veen bemonstering over de jaren 2010 tot en met 2017. 


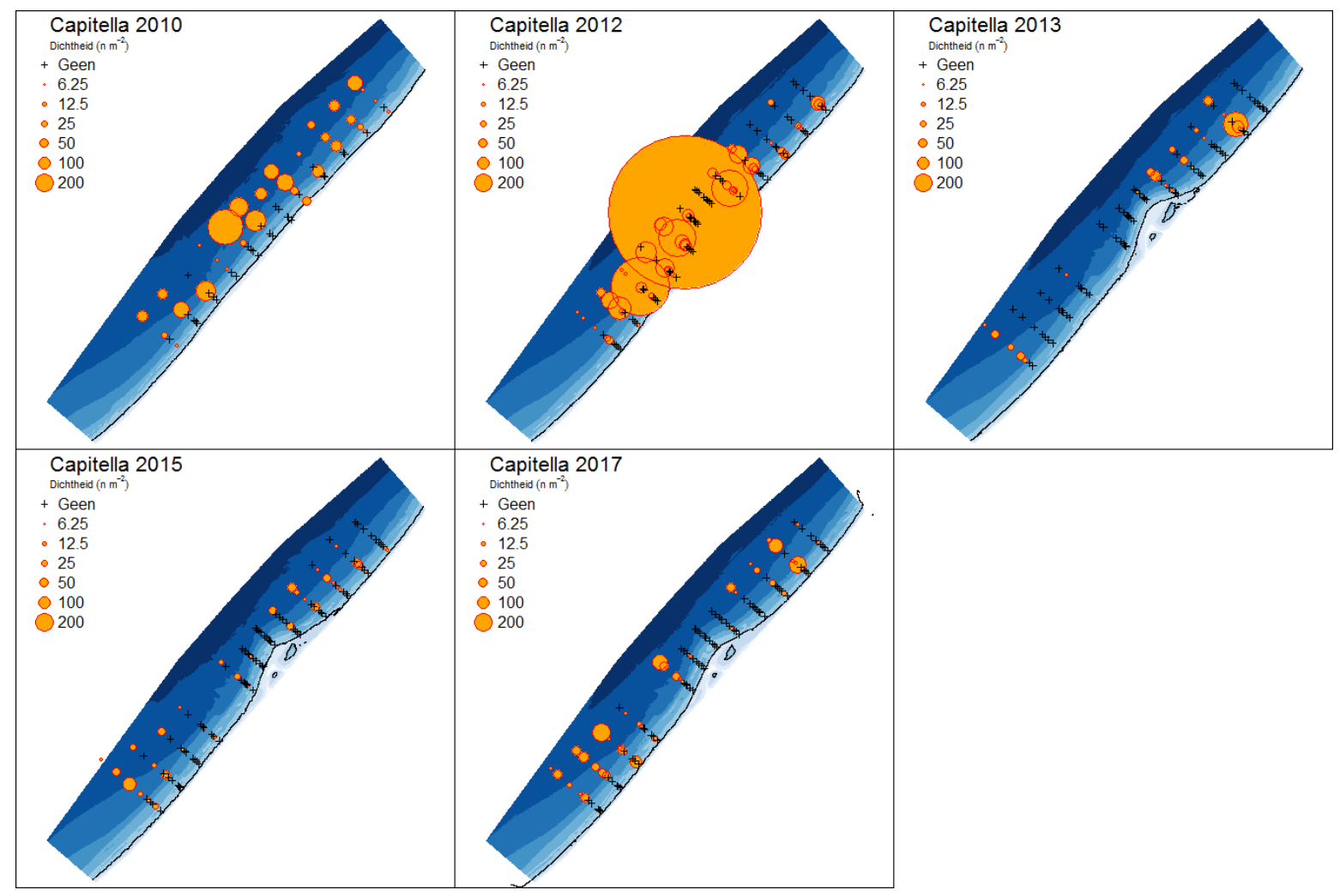

Figuur 80: Verspreidingskaarten Capitella spp. (aantal $\mathrm{m}^{-2}$ ) uit de Van Veen bemonstering over de jaren 2010 tot en met 2017.

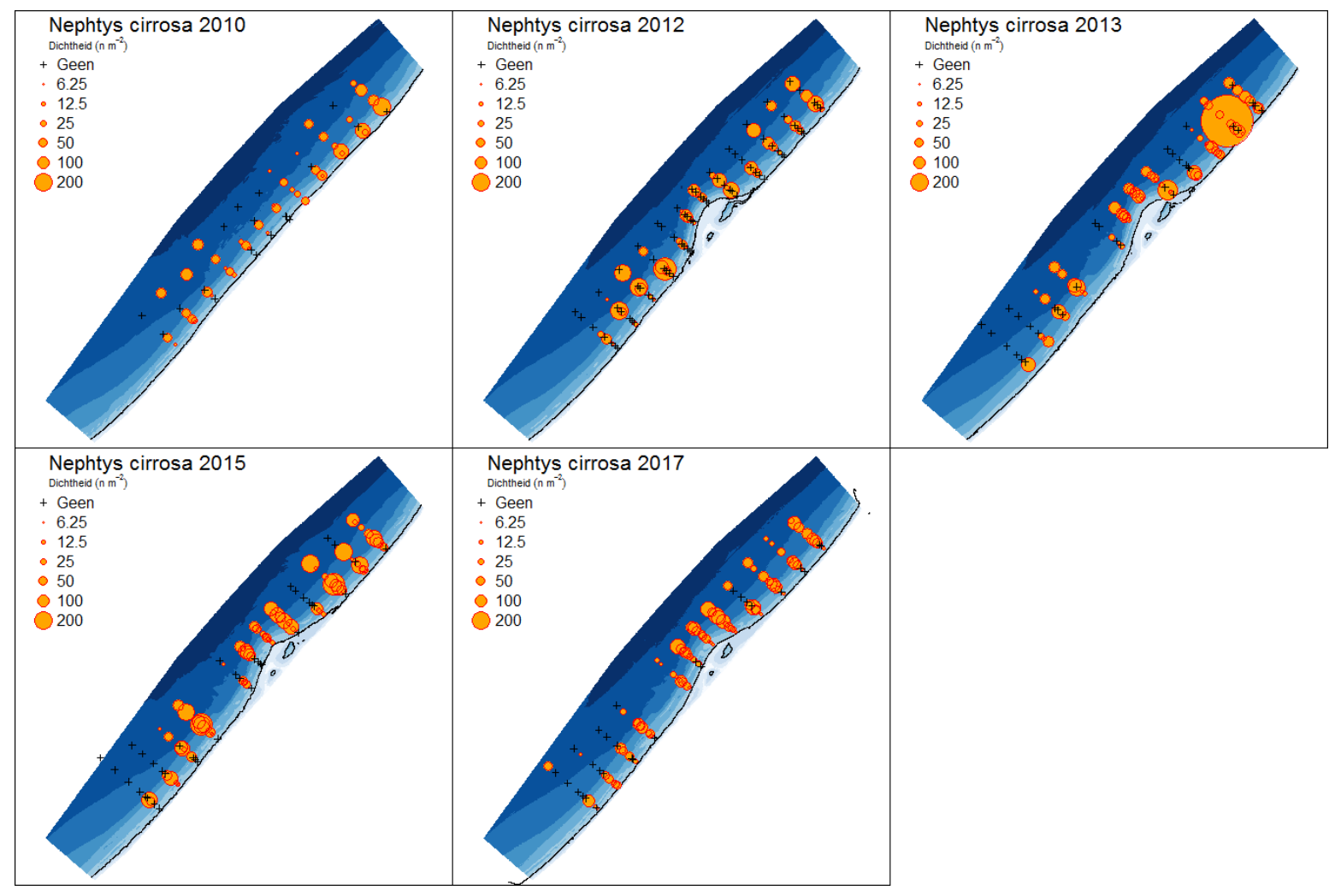

Figuur 81: Verspreidingskaarten Nephtys cirrosa (aantal $\mathrm{m}^{-2}$ ) uit de Van Veen bemonstering over de jaren 2010 tot en met 2017. 


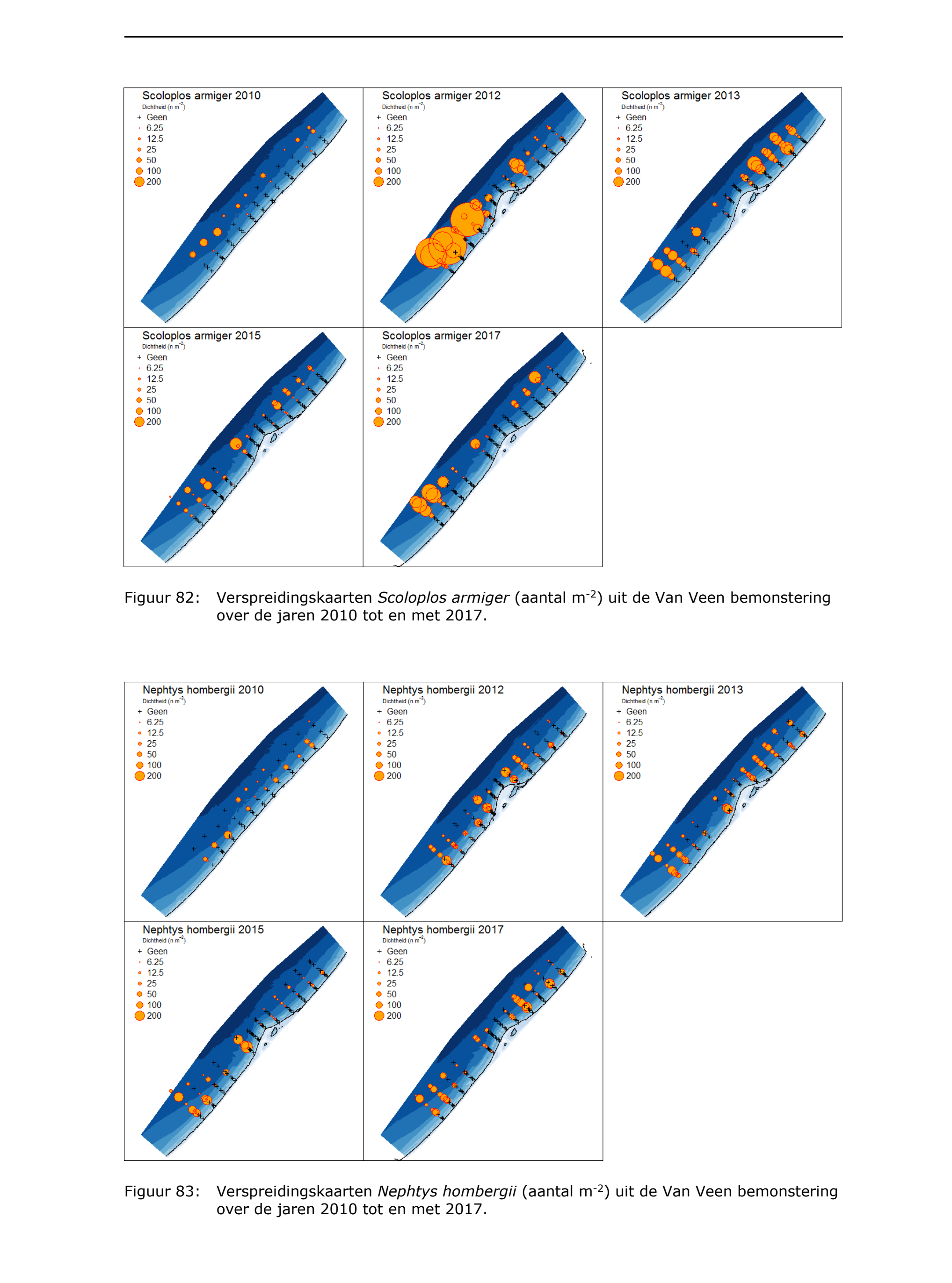




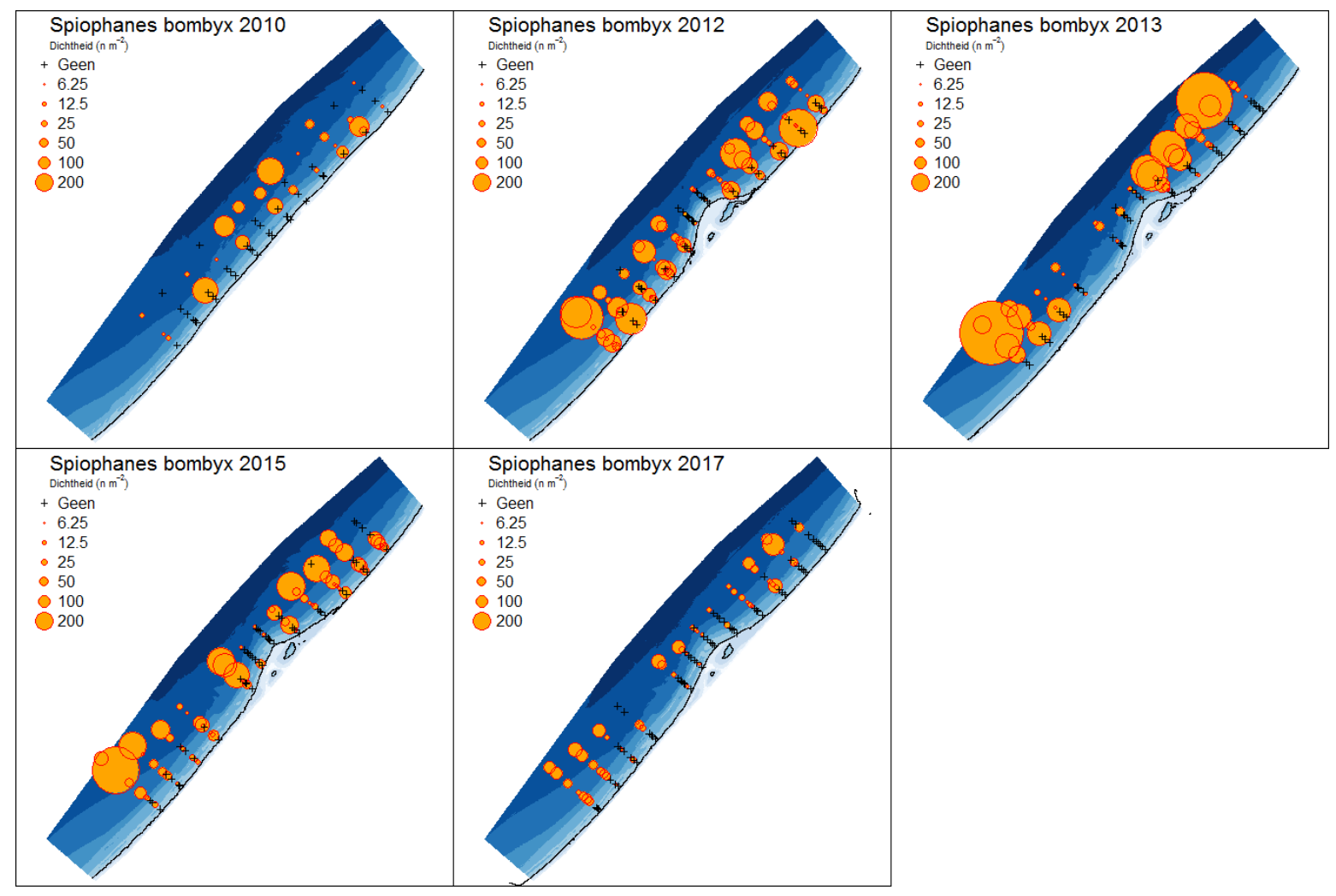

Figuur 84: Verspreidingskaarten Spiophanes bombyx (aantal $\mathrm{m}^{-2}$ ) uit de Van Veen bemonstering over de jaren 2010 tot en met 2017.

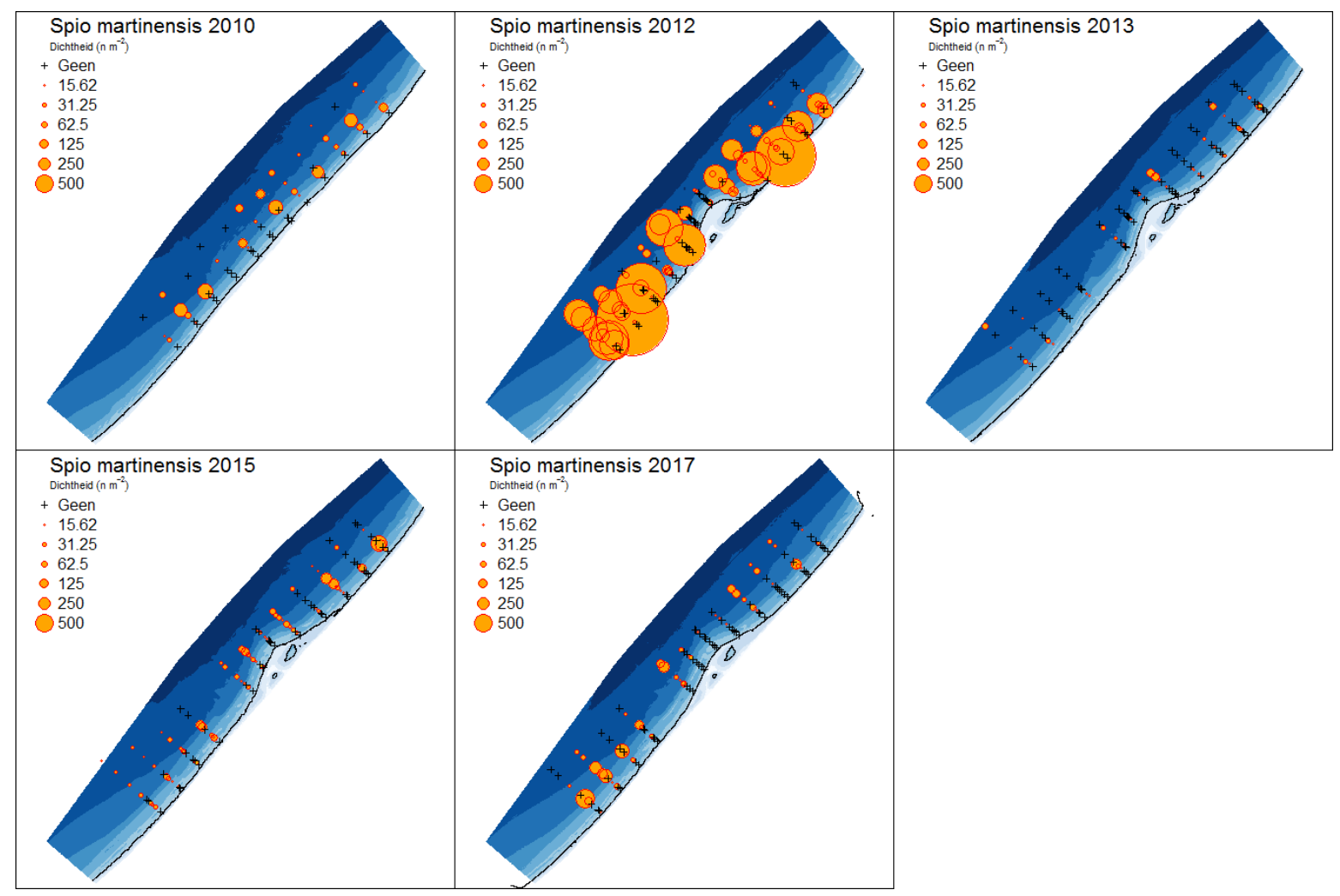

Figuur 85: Verspreidingskaarten Spio martinensis (aantal $\mathrm{m}^{-2}$ ) uit de Van Veen bemonstering over de jaren 2010 tot en met 2017. 
Wageningen Marine Research

T: $+31(0) 317480900$

E: marine-research@wur.nl

www.wur.nl/marine-research

Visitors address

- Ankerpark 271781 AG Den Helder

- Korringaweg 7, 4401 NT Yerseke

- Haringkade 1, 1976 CP IJmuiden
Wageningen Marine Research is the Netherlands research institute established to provide the scientific support that is essential for developing policies and innovation in respect of the marine environment, fishery activities, aquaculture and the maritime sector.

Wageningen University \& Research is specialised in the domain of healthy food and living environment.

\section{The Wageningen Marine Research vision:}

'To explore the potential of marine nature to improve the quality of life.'

\section{The Wageningen Marine Research mission}

- To conduct research with the aim of acquiring knowledge and offering advice on the sustainable management and use of marine and coastal areas.

- Wageningen Marine Research is an independent, leading scientific research institute.

Wageningen Marine Research is part of the international knowledge organisation Wageningen UR (University \& Research centre). Within Wageningen UR, nine specialised research institutes of Stichting Wageningen Research (a Foundation) have joined forces with Wageningen University to help answer the most important questions in the domain of healthy food and living environment. 